\title{
NATIONAL BUREAU OF STANDARDS REPORT
}

8972

\section{Earth Temperature and Thermal Diffusivity at Selected Stations in the United States}

\author{
By \\ T. Kusuda \\ P. R. Achenbach
}

\author{
Prepared for the \\ Office of Civil Defense \\ U.S. Department of the Army
}

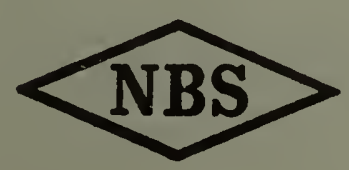

U.S. DEPARTMENT OF COMMERCE

NATIONAL BUREAU OF STANDARDS 


\section{THE NATIONAL BUREAU OF STANDARDS}

The National Bureau of Standards is a principal focal point in the Federal Government for assuring maximum application of the physical and engineering sciences to the advancement of technology in industry and commerce. Its responsibilities include development and maintenance of the national stand. ards of measurement, and the provisions of means for making measurements consistent with those standards; determination of physical constants and properties of materials; development of methods for testing materials, mechanisms, and structures, and naking such tests as may be necessary, particularly for government agencies; cooperation in the establishment of standard practices for incorporation in codes and specifications; advisory service to government agencies on scientific and technical problems; invention and development of devices to serve special needs of the Government; assistance to industry, business, and consumers in the development and acceptance of commercial standards and simplified trade practice recommendations; administration of programs in cooperation with United States business groups and standards organizations for the development of international standards of practice; and maintenance of a clearinghouse for the collection and dissemination of scientific, tech. nical, and engineering information. The scope of the Bureau's activities is suggested in the following listing of its four Institutes and their organizational units.

Institute for Basic Standards. Applied Mathematics. Electricity. Metrology. Mechanics. Heat. Atomic Physics. Physical Chemistry. Laboratory Astrophysics." Radiation Physics. Radio Standards Laboratory:* Radio Standards Physics; Radio Standards Engineering. Office of Standard Reference Data.

Institute for Materials Research. Analytical Chemistry. Polymers. Metallurgy. Inorganic Materials. Reactor Radiations. Cryogenics.* . Materials Evaluation Laboratory. Office of Standard Reference Materials.

Institute for Applied Technology. Building Research. Information Technology. Performance Test Development. Electronic Instrumentation. Textile and Apparel Technology Center. Technical Analysis. Office of Weights and Measures. Office of Engineering Standards. Office of Invention and Innovation. Office of Technical Resources. Clearinghouse for Federal Scientific and Technical Information.**

Central Radio Propagation Laboratory.* Ionospheric Telecommunications. Tropospheric Telecommunications. Space Environment Forecasting. Aeronomy.

* Located at Boulder, Colorado 80301.

** Located at 5285 Port Royal Road, Springfield, Virginia 22171.

DDC Availability

Qualified requestors may obtain copies of this report from the Defense Documentation Center, Cameron Station, Alexandria, Va., 22314.

DDC release of this report to the Federal Clearinghouse is not authorized. 
NATIONAL BUREAU OF STANDARDS REPORT

NBS PROJECT

NBS REPORT

42103-12-4210436

June 22, 1965

8972

\title{
Earth Temperature and Thermal Diffusivity at Selected Stations in the United States
}

\author{
By \\ T. Kusuda \\ P. R. Achenbach \\ Mechanical Systems Section \\ Building Research Division \\ Prepared for the \\ Office of Civil Defense \\ U.S. Department of the Army
}

This report has been reviewed by the Office of Civil Defense and approved for issuance. Approval does not signify that the contents necessarily reflect the views and policies of the Office of Civil Defense.

Contract No. OCD-OS-62-44, Subtask 1211A

NATIONAL BUREAU OF SI for use within the Government. and review. For this reason, th whole or in part, is not autho Bureau of Standards, Washingt the Report has beeri specificall)
IMPORTANT NOTICE

Approved for public release by the

Director of the National Institute of

Standards and Technology (NIST) on October 9, 2015. ess accounting documents intended i subjected to additional evaluation e listing of this Report, either in ve Office of the Director, National by the Government agency for which copies for its own use.

\section{NBS}

\section{U.S. DEPARTMENT OF COMMERCE}





\section{SUMMARY \\ OF \\ RESEARCH REPORT}

8972

EARTH TEMPERATURE AND THERMAL DIFFUSIVITY

AT SELECTED STATIONS IN THE UNITED STATES

by

T. Kusuda

P. R: Achenbach

May 1965

This is a summary of a report which has been reviewed by the Office of Civil Defense and approved for publication. Approval does not signify that the contents necessarily reflect the views and policies of the Office of Civil Defense.

Contract No. OCD-OS-62-44, Subtask $1211 \mathrm{~A}$

National Bureau of Standards

Building Research Division

Washington, D.C.

Summary prepared by

National Bureau of Standards

June 1965 



\section{Findings}

It was found during the analysis that the simplified heat conduction theory based upon a simple harmonic presentation of earth temperatures provided a fair approximation of monthly average earth temperature except near the surface, provided the annual average temperature, the annual amplitude and phase angle of the surface temperature, and the thermal diffusivity are known.

In-situ thermal diffusivities of earth were computed from the observed earth temperature data both by amplitude method and phase angle method. The diffusivities computed by these two methods for each of earth temperature stations showed reasonably good agreement for most of the stations. Moreover, most of the diffusivity values were in the range from 0.015 and $0.035 \mathrm{ft}^{2} / \mathrm{hr}$. The difference in the therma 1 diffusivities calculated by the two methods could not be attributed definitely to known causes. The annual averages of monthly average earth temperature, as expected, were very close to the annual average outdoor air temperature and to the Collins' ground water temperature of a given location. The annual amplitude of the monthly average earth surface temperature, however, did not show a good correlation to the annual amplitude of monthly average outdoor air temperature. The phase angle measured from January lst for monthly average earth temperatures and air temperatures were also compared. While the phase angle values of air temperature cycle showed a consistent value of approximately 0.6 radian ( 5 weeks), the earth surface temperature phase angles ranged from 0.4 radian and 0.8 radian ( 3.3 to 6.7 weeks). 
More extensive studies are necessary to establish a functional relation between earth surface temperature and outdoor air temperature for various types of soil, earth surface characteristics, and climatic conditions.

Although all available earth temperature data were compiled during this study, the stations were widely separated in most of the southern and western states. It is recommended, therefore, that data be obtained at additional stations in those regions during future studies. 
The National Bureau of Standards had investigated thermal

environment of a family shelter for various test conditions experimentally and has been developing analytical and numerical computational programs that predict the thermal performance of occupied underground shelters. Details of these programs have been reported previously. The numerical program was designed to predict, by a digital computer, temperature and humidity in underground shelters for simulated occupancy conditions, of any size, shape and construction detail for any combination of properties of the surrounding soil, outdoor weather conditions, number, activity and density of occupants, and type of cooling and ventilating facilities. The thermal performances of several prototype shelters with simulated occupants of several different sizes have been adequately simulated by the present computer program. The computer program is basically capable of predicting thermal environment of many different underground structures if input parameters are accurately known, such as was the case for the prototype shelters. Some of the important, yet not well defined, input parameters for underground thermal performance are temperature and properties of the earth surrounding the shelter, and conditions of outdoor air which is usually used for shelter ventilation. The earth temperature, earth properties and outdoor air conditions are interdependent near the earth's surface, and these parameters vary with time and from locality to locality throughout the United States. Thus, it was decided that the earth temperature data and outdoor weather data should be analyzed to establish reasonable computer input data for the purpose of predicting the shelter thermal 
environment and to facilitate design of economical mechanical systems for underground shelters. This report covers the analysis of earth temperature data.

- A total of 63 sets of monthly average earth temperature data, including some that had been already published and additional data obtained from the climatological data of the U.S. Weather Bureau, have been tabulated and analyzed in this report. This technique employs a simple harmonic heat transfer equation of earth temperature vs. time to calculate the earth temperatures from a few characteristics such as annual average temperature, surface temperature, annual temperature amplitude, thermal diffusivity, and surface temperature phase angle from a selected reference point. These characteristic values were analyzed using least-squares constant which were obtained by fitting a simple harmonic equation to the data of the monthly average earth temperatures. The higher harmonic terms in describing annual cycle of monthly average earth temperatures were neglected in this analysis.

By knowing the characteristics described above, earth temperature vs. depth may be calculated for various climatic regions and for various thermal properties. Simplified analytical studies on shelter heat transfer, however, require only an average earth temperature surrounding the shelter at the time of shelter entry instead of the detailed temperature distributions. The average earth temperatures from surface to 10-ft depth have also been calculated using these same earth temperature characteristics. 
TABLE OF CONTENTS

PAGE

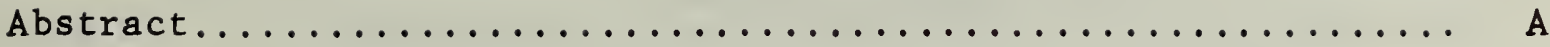

1. Introduction............................ 1

2. Location of Earth Temperature Stations............... 3

3. Analysis of Earth Temperature Data................ 8

4. Simplified Heat Conduction Theory of Undisturbed Earth.... 12

5. Analyses of Thermal Diffusivity of the Earth by

Simplified Theory.......................... 14

6. Correlation of Earth, Air, and Ground Water Temperature... 19

7. Calculations of Earth Temperatures................. 29

8. Integrated Average Temperature of Upper 10-ft Stratum..... 31

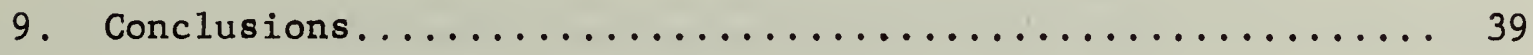

10. Recommendations.......................... 42

11. Appendix: Discussion of Least-Squares Technique........ 43

12. Earth Temperature References .................... 49 


\section{LIST OF TABLES}

Table 1

List of earth temperature stations and results of least-squares analysis

Table 2

Summary of site characteristics and earth, air, and ground water thermal characteristics at 18 selected stations

Table 3

L1st of air temperature stations located near the earth temperature stations

Table 4

Annual maxima and minima of air temperature and integrated average earth temperature from surface to 10-ft depth

Tables ST-1 to

Summary of observed earth temperatures, results of ST -63 least-squares analysis, and calculated earth temperatures using the least-squares constants for all of 63 earth temperature stations

Tables STA-1 to

Calculated earth temperatures for selected depths and STA -63 thermal diffusivities, and integrated average temperature for upper 10-ft earth stratum for 63 earth temperature stations 


\section{LIST OF FIGURES}

Figure 1

F1gure 2

F1gure 3

Figure 4

Figure 5

Figure 6

Figure 7

Figure 8

Figure 9

Figures ST-1 to ST-19

Figures $\mathrm{SP}-1$ to SP -19
Graphical distribution of stations for which earth temperature data are reported, and Collins' well-water isotherms for the 48 contiguous states

Comparison of least-squares curve, 5-year norm, and observed temperatures at Lexington, Kentucky

Thermal diffusivities computed by amplitude method and phase angle method

Annual average earth and water temperature vs. annual average air temperature

Annual amplitude of monthly average afr temperature vs. annual earth surface temperature amplitude

Annual cycles of monthly average dafly solar insolation and monthly average outdoor air temperature for Washington, D. C. and Minneapolis, Minnesota

Phase angle relations between the annual cycles of monthly average alr and earth surface temperatures

Dimensionless parameters for calculation of integrated depth average earth temperature

Calculated earth temperature and integrated depth average earth temperature plotted against depth from the surface in August and February for the station at Lexington, Kentucky

Annual average earth temperature and amplitude plotted against depth

Earth temperature phase angle plotted agalnst depth 


\section{NOMENCLATURE}

Symbol

Unit

A

B

BA $\left(\mathrm{BA}^{\prime}\right) \quad \begin{aligned} & \text { Amplitude of the monthly average air } \\ & \text { temperature }\end{aligned}$

BO

$\mathrm{C}_{\mathrm{n}}$

D

$\mathrm{D}(\mathrm{B})$

$\mathrm{D}(\mathrm{P})$

e

$\mathrm{K}$

L

$\log$

$\mathrm{N}$

n

P

$\mathrm{PA}\left(\mathrm{PA}^{\prime}\right)$

Annual average earth temperature: (LeastSquares Constant)

Amplitude of the annual cycle of the monthly average earth temperature at a given point (Least-Squares Constant)

Projected earth surface temperature amplitude (B at $\mathrm{x}=0$ )

Earth temperature amplitude of nth harmonic

Thermal diffusivity of earth

Thermal diffusivity of earth calculated by the amplitude method

Thermal diffusivity of earth calculated by the phase lag method

Base of the natural logarithm

Index for identifying temperature data at a given time

Depth from the earth's surface

Natural logarithm

Index for denoting total number of

temperature data at a given depth

Integer referring to nth harmonic of the

Fourier series expression of temperature cycle

Phase angle of the earth temperature cycle for given $\mathrm{x}$

$\left(\mathrm{ft} \mathrm{t}^{2} / \mathrm{hr}\right)$

(dimensionless)

(dimensionless)

(dimensionless)

(radian)

(radian) 
Symbol

Unit

PO

Projected phase angle at the earth's

surface $(x=0)$

(radian)

$S D$ deviation

Standard / of the observed earth

temperatures from those calculated by the

least-squares fit equation

$t$

Calculated monthly average earth temperature $\left({ }^{\circ} \mathrm{F}\right)$

Observed monthly average earth temperature ( ${ }^{\circ} \mathrm{F}$ )

Average earth temperature from surface to a depth L ( $\left.{ }^{\circ} \mathrm{F}\right)$

Period of the temperature cycle (= 8766 hrs)

TA (TA') Annual average air temperature

$\left({ }^{\circ} \mathrm{F}\right)$

Ground water temperature

Downward distance coordinate from the earth's surface

$\alpha, \alpha_{1}, \alpha_{2} \quad$ Temperature functions

(radian)

nth harmonic

(dimensionless)

$\xi_{1}, \xi_{2}, \xi_{3}, \operatorname{Tr} 1$ gonometric functions

$\xi_{4}, \xi_{5}$

$\omega$

Angular velocity factor $=\frac{2 \pi}{T}$

$(\operatorname{radians} / \mathrm{hr})$

$\theta$

Elapsed time from January lst

(hr)

$\sqrt{\frac{\pi}{D T}} I=$ dimensionless depth

Phase angle for integrated depth average

( $\operatorname{rad} 1 \mathrm{an})$

Dimensionless amplitude for integrated depth average 
T. Kusuda and P. R. Achenbach

\section{ABSTRACT}

To provide information related to the heat transfer in underground installations, 63 sets of data showing annual variations of monthly average earth temperatures at various depths throughout the 48 contiguous states of the United States of America have been compiled and analyzed for the Office of Civil Defense. These data have been used to compute the annual average amplitude and phase angle of the earth temperature by a least-squares method. Thermal diffusivities of earth computed from the observed temperature data by both the amplitude method and phase lag method were compared for selected earth temperature stations. The monthly average earth temperature at depth intervals of two feet to a depth of 10 feet and the annual maximum and minimum integrated average temperatures in this region were calculated for each station for a selected value of thermal diffusivity using the results of the least-squares analysis. Annual average values of earth temperature and the amplitude and phase angle of the annual cycle of earth surface temperature were compared with the corresponding values of air and ground water temperatures. 
EARTH TEMPERATURE AND THERMAL DIFFUSIVITY

AT SELECTED STATIONS IN THE UNITED STATES

by

T. Kusuda and P. R. Achenbach

National Bureau of Standards

\section{Introduction}

Earth temperature is one of the most important parameters affecting heat transfer in underground installations. Recent studies of underground protective shelters have clearly indicated the immediate need for earth temperature design data. $1,2,3 /$ The environment in an underground protective shelter can be improved considerably if the heat absorbing capacity of the surrounding earth is effectively utilized. The total heat absorbing capacity of earth, however, cannot be accurately determined unless its temperature and thermal properties are known. The earth temperature varies with latitude, weather conditions, time of year, altitude, landscaping, shading, neighboring buildings, earth surface conditions, soil properties, rainfa11, and other factors.

Although the exact ground temperature at a specific site can be obtained only by direct measurements, information on the general distribution of the natural ground temperature throughout the United States is, nevertheless, worth obtaining. Such information would be useful from the standpoint of shelter planning on a nationwide basis and would aid in determining the equipment requirements for ventilation, air-conditioning and heating of various size shelters.

The primary purpose of this report is to compile all available annual cycles of monthly average earth temperatures in the depths suited to heat transfer calculations in underground protective structures. 
Numerous earth temperature data are scattered throughout the literature, but little effort has been made in the past to compile them into a nationwide summary except for the work of Fitton and Brook $\underline{4}$ / and that of Jen-Hu Chang. compiled by these workers have, however, been obtained less than a foot from the earth's surface and are not particularly suited for heat transfer studies on underground structures.

For heat transfer studies on underground protective structures, earth temperatures at depths between $3 \mathrm{ft}$ and $10 \mathrm{ft}$ are of particular significance. A study was undertaken under the sponsorship of the Office of Civil Defense to secure earth temperature data at these depths from several existing soil temperature records, $\underline{4,5,6,7,8,9,10 /}$ either published or unpublished. Data compiled and analyzed in this paper are monthly average earth temperatures for periods ranging from one year to several years.

The analysis of earth temperature data includes the following parts :

(a) The determination of averaged annual cycles of monthly average earth temperatures at various depths from the several years' records at 63 stations.

(b) Least-squares fitting of observed data to a simple harmonic function to obtain annual average temperature, annual amplitude of monthly averages, and phase angle of the temperature cycle at various depths for 63 stations. 
(c) Calculation of thermal diffusivity of the earth at 29 stations using both the amplitude and phase angle techniques.

(d) Comparison of observed earth temperatures with calculated earth temperatures, using the thermal diffusivity as determined in (c) and with least-squares constants as determined in (b) at each depth where the observations were made.

(e) Calculation of earth temperature from the surface to a depth of $10 \mathrm{ft}$ at two-foot Intervals and average earth temperature of the same reglon for selected values of thermal diffusivities and earth temperature character1st1cs.

In order to compare the earth temperatures with alr temperatures, annual temperature cycles of outdoor alr were also collected from weather stations in the vicinity of the ground temperature stations. The earth temperatures were also compared with ground water temperatures reported by Collins. $11 /$

\section{Location of Earth Temperature Stations}

The many parameters which affect earth temperature can be classifled Into the following three major groups:

(1) Geographical character1stics: lat1tude, alt1tude, climat1c conditions.

(2) Site characterlstics: surface condition, landscaping, shading, nelghboring installations, water table.

(3) Earth characteristics: thermal and physical properties of earth (1ncluding molsture content), packing density, etc. 
Since many of these parameters change in a seasonal cycle, or Irregularly with time, it is impossible to predict exactly the earth temperature at any given location for any given time in the future, particularly at locations near the earth's surface. Earth temperature predictions, therefore, are of a statistical nature and some deviation from the average is to be expected in any given day, season, or year.

Because earth temperatures are affected by so many factors, it would be desirable in analyzing data at different locations for comparison with each other to keep as many of these factors, such as earth cover, shading, and earth density, constant in order to arive at meaningful conclusions. However, this approach was impractical for the most part in the present study since the original temperature data were taken for a variety of purposes by different investigators, and the total number of stations of observation in the United States was quite limited. The majority of the ground temperature data avallable for this study were obtained in undsturbed earth at stations on open flat ground, efther bare or grass-covered. 
The geographical locations of the stations for which earth temperature data are complied in this study are indicated in Fig. 1. Collins' well-water temperature 1sotherms $11 /$ at depths of $30 \mathrm{ft}$ to $60 \mathrm{ft}$ are superimposed on Fig. 1. These data w1ll be used later to correlate the ground water temperature with earth temperature. E1ghteen filled circles and seven open circles on Fig. 1 indicate the stations for which data have been newly analyzed during the course of this study. The monthly average earth temperatures for three consecutive years' span were obtained and analyzed for the majority of these twenty-five bisected stations. The stations marked with/open circles in Fig. 1 are those for which earth temperature data had already been reduced to an annual cycle of average monthly temperatures by other investigators for publication. Unfortunately, the majority of the data obtained from these latter sources did not contain pertinent information with regard to most of the site and soll characteristics, although they are still helpful in studying the effect of the parameters which were cited.

A total of 63 sets of data has been complled and analyzed in this study to show the effect of comblnations of the above parameters on earth temperature. Table 1 is a list of the earth temperature stations Indicated in Fig. 1. 


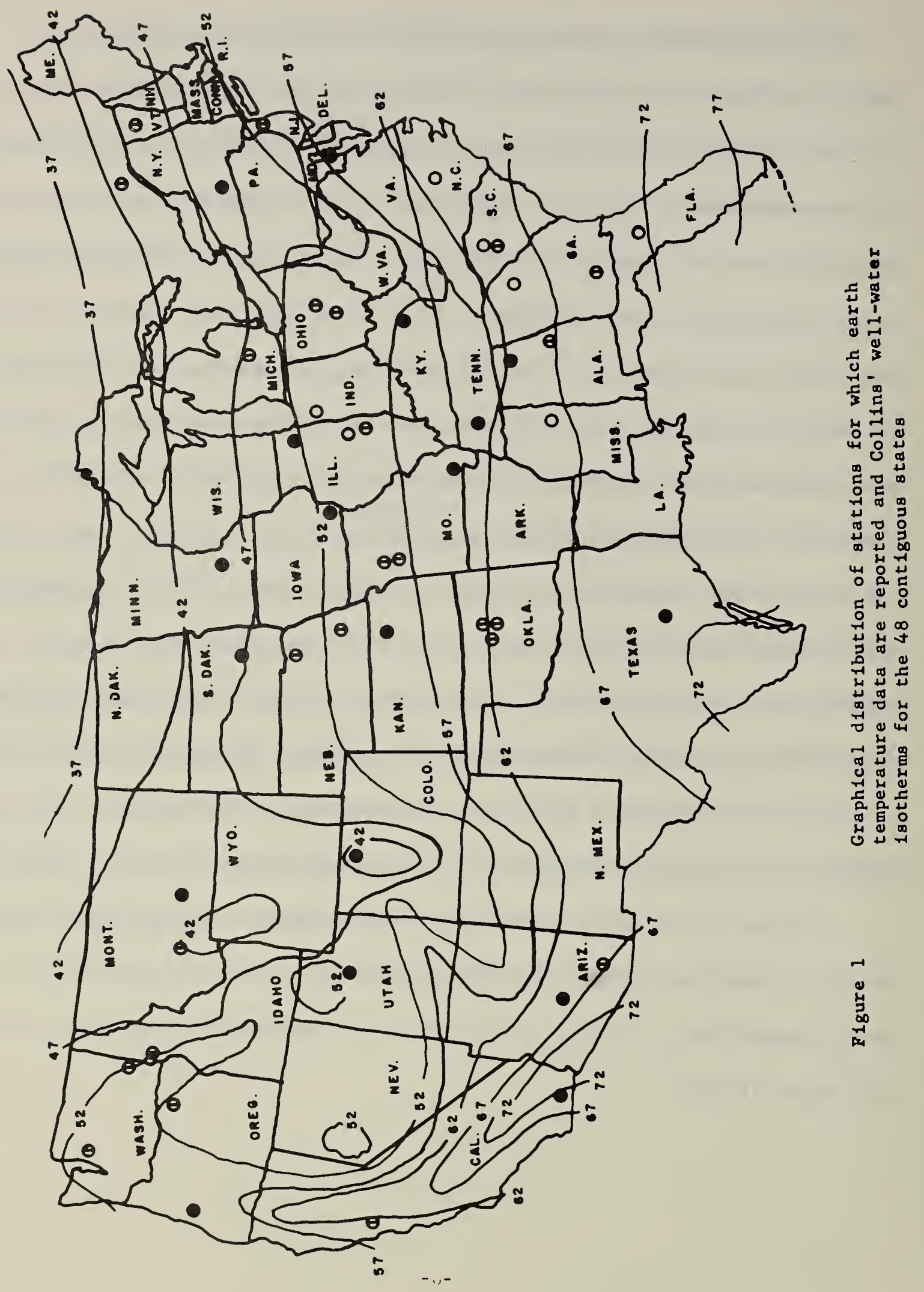


L1st of earth temperature stations and results of least-squares analys 18

\begin{tabular}{|c|c|c|c|c|c|c|}
\hline \multirow[t]{2}{*}{ Table } & \multirow[t]{2}{*}{ Station } & \multirow[t]{2}{*}{ State } & $\begin{array}{l}\text { Annual } \\
\text { Avg. Barth } \\
\text { Temp. }\end{array}$ & $\begin{array}{c}\text { Temp. } \\
\text { Amplitude at } \\
\text { Earth's Surface }\end{array}$ & \multicolumn{2}{|c|}{$\begin{array}{l}\text { Phase Angle } \\
\text { of Earth Temp. } \\
\text { at Surface } \\
\end{array}$} \\
\hline & & & (A) ${ }^{\circ} E$ & $(B O)^{\circ} F$ & (PO) radians & \\
\hline$\star S T-1$ & Auburn & Alabama & 65 & 17 & 0.49 & \\
\hline$t * S T-2$ & Decatur & Alabama & 59 & 21 & 0.45 & \\
\hline$t * \mathrm{ST}-3$ & Tempe & Ar1zone & 70 & 20 & 0.47 & \\
\hline$\star S T-4$ & Trics on & Ar1zona & 75 & 18 & 0.77 & \\
\hline$f \star S T-5$ & Brawley & California & 79 & 20 & 0.60 & \\
\hline$S T-6$ & Davis & California & 66 & 19 & 0.63 & \\
\hline$\neq \mathrm{sT}-7$ & Port Collin & Colorado & 50 & 24 & 0.54 & \\
\hline$+\mathrm{ST}-8$ & Fort Coll1n & Colorado & 50 & 24 & 0.54 & \\
\hline$\neq \star S T-9$ & Fort Coll1n & Colorado & 50 & 26 & 0.54 & \\
\hline$\neq \mathrm{ST}-10$ & Gainesville & Florida & 74 & - & -- & \\
\hline$+\mathrm{sT}-11$ & Athen: & Georgia & 67 & -- & -- & \\
\hline ST-12 & Tifton & Georgia & 71 & -. & -- & \\
\hline$\star S T-13$ & Moscow & Idaho & 47 & 18 & 0.73 & \\
\hline$\star$ ST- 14 & Argonne & Illinois & 51 & 23 & 0.70 & \\
\hline$S T-15$ & Lemont & Ill1nois & 52 & 23 & 0.66 & \\
\hline$\star \mathrm{ST}-16$ & Urbane & Illinols & 53 & 25 & 0.62 & \\
\hline ST-17 & Urbana & Il11nois & 55 & -- & - & \\
\hline$\star \mathrm{ST}-18$ & West Lafayette & Indiana & 52 & -- & -- & \\
\hline$t * \mathrm{ST}-19$ & Burlington & Iowa & 54 & 30 & 0.57 & \\
\hline$t \star S T-20$ & Manhattan & Renses & 55 & 26 & 0.61 & \\
\hline$S T-21$ & Lexington & Kentucky & 55 & 23 & 0.60 & \\
\hline$\star S T-22$ & Lexington & Rentucky & 58 & 22 & 0.75 & \\
\hline$\neq * S T-23$ & Upper Marlboro & Maryland & 56 & 25 & 0.56 & \\
\hline $\mathrm{ST}-24$ & East Lensing & Mich1gan & 50 & 24 & 0.60 & \\
\hline$S T-25$ & East Lansing & Michigan & 51 & 24 & 0.59 & \\
\hline$S T=26$ & East Lansing & Michigan & 50 & 24 & 0.60 & \\
\hline$S T-27$ & East Lansing & Michigan & 50 & 24 & 0.60 & \\
\hline ST- 28 & East Lansing & Michigan & 50 & 24 & 0.65 & \\
\hline$\neq \star S T-29$ & St. Paul & Minnesota & 48 & 25 & 0.65 & \\
\hline$+\mathrm{sT}-30$ & State Univ. & $M 1=1 s s 1 \mathrm{pp} 1$ & 67 & 21 & 0.58 & \\
\hline$\star S T-31$ & Faucett & M1ssour 1 & 54 & 20 & 0.65 & \\
\hline ST- 32 & Ranses C1ty & Missour 1 & 54 & 22 & 0.56 & \\
\hline$\neq \star S T-33$ & S1keston & M1:sour 1 & 57 & 25 & 0.59 & \\
\hline$\star S T-34$ & Boreman & Montana & 44 & 21 & 0.68 & \\
\hline$+\mathrm{ST}-35$ & Boreman & Montana & 44 & 21 & 0.63 & \\
\hline$f \star S T-36$ & Hunt ley & Montana & 50 & 25 & 0.47 & \\
\hline ST- 37 & Lincoln & Nebraska & 54 & 28 & 0.52 & \\
\hline ST- 38 & Lincoln & Nebraska & 53 & 28 & 0.52 & \\
\hline ST- 39 & Norfolk & Nebraska & 53 & 24 & 0.54 & - \\
\hline$S T-40$ & New Brungwick & New Jervey & 53 & 21 & 0.69 & \\
\hline ST-41 & Ithaca & New York & 49 & 19 & 0.69 & \\
\hline$t \star S T-42$ & Ithaca & New York & 49 & 19 & 0.64 & \\
\hline$+\mathrm{ST}-43$ & Ralelgh & North Carolina & 62 & $\ldots$ & -- & \\
\hline$+\mathrm{ST}-44$ & Columbus & Oh10 & 53 & 22 & 0.65 & \\
\hline ST -45 & Coshocton & Oh10 & 52 & 22 & 0.67 & \\
\hline ST-46 & Barnedall & Oklehome & 65 & 21 & 0.65 & \\
\hline ST-47 & Hominy & Oklahoma & 63 & 21 & 0.73 & \\
\hline$S T-48$ & Lake Hefner & Okl ahoma & 64 & 23 & 0.63 & \\
\hline ST-49 & Pawhuska & Oklehoma & 62 & 22 & 0.61 & \\
\hline$\star \mathrm{ST}-50$ & Ottawa & Ontario & 47 & 21 & 0.64 & \\
\hline$f \star S T-51$ & Corvallis & Oregon & 56 & 18 & 0.53 & \\
\hline ST- 52 & Pendlet on & Oregon & 53 & 26 & 0.48 & \\
\hline ST- 53 & Cal houn & South Carolina & 64 & 22 & 0.49 & \\
\hline$\star S T-54$ & Unton & South Carolina & 59 & 20 & 0.67 & \\
\hline$f \star S T-55$ & Madison & South Dakota & 47 & 26 & 0.59 & \\
\hline$f * S T-56$ & Jackson & Tennessee & 60 & 20 & 0.44 & \\
\hline$t \star S T-57$ & Temple & Texas & 70 & 21 & 0.58 & \\
\hline$\neq * S T-58$ & Temple & Texas & 71 & 21 & 0.59 & \\
\hline$t * S T-59$ & Salt Lake City & Utah & 51 & 21 & 0.48 & \\
\hline$S T-60$ & Burlingt on & Vermont & 49 & -- & -- & \\
\hline$S T-61$ & Pullman & Washington & 48 & -- & -- & \\
\hline$S T-62$ & Pullman & Washington & 48 & 19 & 0.50 & \\
\hline$\star S T-63$ & Seattle & Washington & 53 & 15 & 0.64 & \\
\hline
\end{tabular}

* Earth temperature station where the data are analyzed for the thermal diffusivity (29 tatione)

+ - Earth temperature data newly acquired (25 otations) 


\section{Analysis of Earth Temperature Data}

The observed earth temperatures at various depths, averaged arithmetically in monthly periods, were tabulated for the 63 stations in Tables ST-1 through ST-63. In addition to presenting the annual cycle of monthly average earth temperatures, the observed earth temperatures were analyzed to find best annual averages, depth amplitude, and depth phase angles based upon the assumption that the earth temperature can be represented by a simple harmonic time function. This assumption may not represent the best possible mathematical model from the standpoint of meteorological or geophysical considerations, but it is probably satisfactory for the purpose of analysis of heat transfer in underground protective structures. The simple harmonic representation of an annual cycle of monthly average soll temperatures is reasonably accurate, as shown by the analyses of Penrod ${ }^{2}, 9 /$ and Carson. $10 /$ Moreover, the constants of the simple harmonic expression of the earth temperature cycle can be related to thermal diffusivity of the soil at any station for which temperature data are taken. 
Equation (1) is a simple harmonic function that can be used to represent an earth temperature cycle.

$$
t=A-B \cos \left(\frac{2 \pi}{T} \theta-P\right)
$$

where: $t$ is the monthly average earth temperature, ${ }^{\circ} \mathrm{F}$

$\theta$ is the time coordinate which is taken as zero on January 1 , hr

$\mathrm{T}$ is the perfod of the temperature cycle $=8766 \mathrm{hr}$

$A$ is the annual average earth temperature, ${ }^{\circ} \mathrm{F}$

$B$ Is the annual amplitude of the monthly average temperature cycle, ${ }^{\circ} \mathrm{F}$

$P$ is the phase angle of the earth temperature cycle, radians. The values of $A, B$, and $P$ in equation ( 1 ) have been determined in two different ways by other authors. Penrod $8,9 /$ computed A by arithmetic average of 12 monthly average earth temperatures, B as one-half the difference between the maximum and minimum monthly average temperatures, and $\mathrm{P}$ by a rather complicated graphical calculation. Carson 10/ expressed the annual cycle of monthly average earth temperatures at a given depth by a Fourier series containing six harmonics and computed $A, B$, and $P$ from the basic harmonic terms of the Fourler expression. Both Penrod and Carson computed their parameters for each year separately.

It should be pointed out, however, that the numerical value of $P$ is rather arbitrary, depending upon the origin of the time coordinate system. 
In this study, earth temperature cycles of several years' record of monthly averages have been fitted to equation (1) by a least-squares method. That 1s, the values of constants $A, B$, and $P$ have been determined, so that the sum of the squares of differences between the fitted harmonic curve and the observed values are a minimum. Fig. 2 shows typical annual cycles of monthly average earth temperatures at the surface and at the 10-ft depth at a site In Lexington, Kentucky.

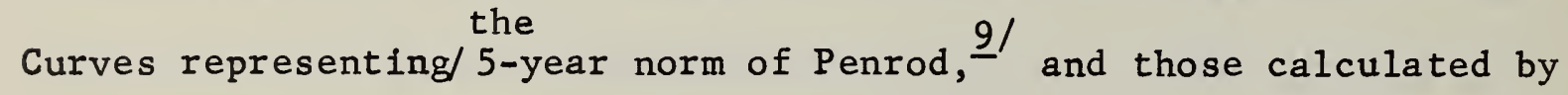
the least-squares technique are also shown on F1g. 2. A good agreement exists between the least-squares fitted curve and the 5-year norm curve, despite the considerable scatter in earth surface temperature data.

The detail of the mathematical development of the least-squares technique is presented in the Appendix. The values of $A, B$, and $P$, and the standara deviation of the observed data from the value calculated by equation (1), were determined at each depth for 63 sets of earth temperature data and are shown in the ST tables. The absolute value of the phase angle, $P$, is dependent upon the coordinate system of $\theta$ of equation ( 1 ) and is less meaningful than the difference between the values of $P$ at two consecutive depths. As seen from the ST tables, the annual amplitude of the earth temperature, B, decreased as the depth Increased, whereas the annual average of the earth temperature was practically invariant with respect to the depth, except for irregularities near the surface region. It is also observed from the ST tables that the phase angle, P, increased as the depth. Increased. 


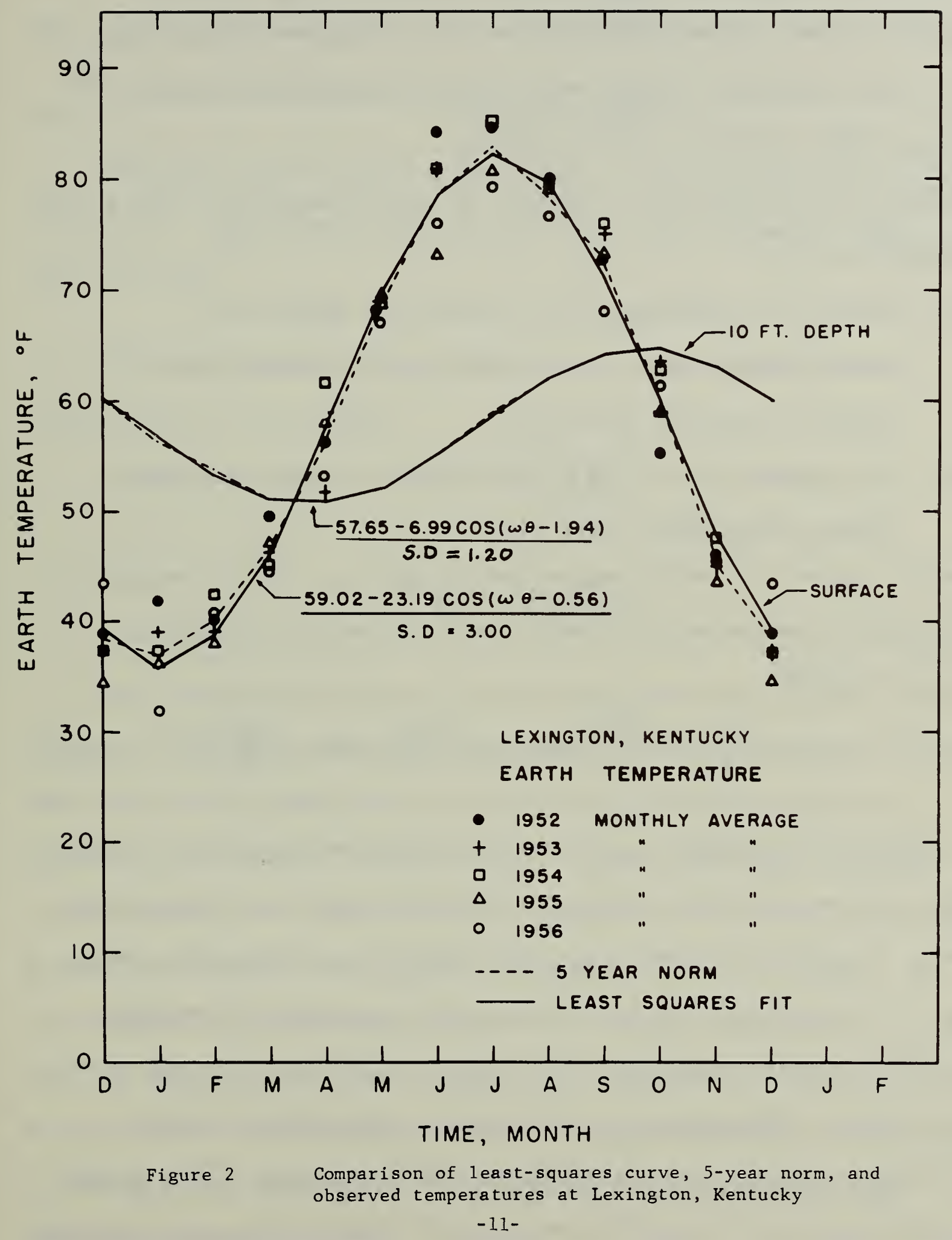




\section{Simplified Heat Conduction Theory of Undisturbed Earth}

The earth temperature oscillation near the surface from the standpoint of heat conduction theory has been discussed in various texts of heat transfer; notable among them are Carslaw and Jaeger's 12 / and Eckert's 13/ treatments of the problem.

Usually the mathematical treatment of earth temperature starts with the assumption that:

(1) Earth is a homogeneous heat conducting medium of a semi-Infinite solid system, the thermal diffusivity of which is constant throughout.

(2) The temperature of the surface exposed to the atmosphere varies periodically with time.

For such a system the earth temperature at depth, $x$, can be computed by the following equation when a steady cyclic pattern is established within earth:닌

$$
t=A+\sum_{n=1}^{\infty} e^{-\sqrt{\frac{n \pi}{D T}} x} \operatorname{Cn} \cos \left(\frac{2 \pi n \theta}{T}-\delta n-\sqrt{\frac{n \pi}{D T}} x\right)
$$

where $C n$ and $\delta n$ correspond to the amplitude and phase angle of the $n$th harmonic of the prescribed periodic temperature function at the ground surface. As long as the earth surface temperature is perfodic, and as long as the assumptions (1) and (2) are valid, equation (2) exactly describes the earth temperature with proper evaluation of $\mathrm{Cn}$ and $\delta \mathrm{n}$ as well as thermal diffusivity D. Furthermore, when higher harmonics corresponding to $n \geq 2$ are not significant, as in the case of the annual temperature cycle of the monthly average soll temperatures, equation (2) becomes simply the following form: 


$$
t=A-B O e^{-\sqrt{\frac{\pi}{D T}} x} \cos \left(\frac{2 \pi \theta}{T}-\sqrt{\frac{\pi}{D T}} x-P O\right)
$$

By comparing (1) and (3), B $=B O e^{-\sqrt{\frac{\pi}{D T}} x}$

and

$$
P=P O+\sqrt{\frac{\pi}{D T}} x
$$

Relations (4) and (5) Indicate that a linear relationship exists between the logarithmic amplitude and depth and between the phase angle and the depth.

Relations (4) and (5) also suggest the evaluation of thermal diffusivity by the formulas

$$
\begin{aligned}
& D(B)=\frac{\pi}{T}\left[\frac{x}{\log \frac{B O}{B}}\right]^{2} \\
& D(P)=\frac{\pi}{T}\left[\frac{x}{P-P O}\right]^{2}
\end{aligned}
$$

The preceding relations of earth temperature and thermal diffuslvity had been applied as far back as 1811 by Lord Kelvin to the mean earth temperature curves based on Forbe's 18-year record in Edinburgh, Scotland. 12/ Kelvin did not ignore the higher harmonics for the temperature equations and calculated the diffusivity not only by the first harmonic but also by the higher harmonics as well. He had obtalned a good agreement between the thermal diffusivities deduced from the amplitude and that from the phase angle of the first harmonic. He was, however, less successful for the higher harmonics in obtaining a good agreement between the diffusivities calculated by the two different methods. 
5. Analyses of Thermal Diffusivity of the Earth by Simplifled Theory

Several other Investigators have applied the simplified theory of the preceding section to 1 imited amounts of earth temperature data. In this analysis, the results of the least-squares fitting for several earth temperature stations were selected for graphical representation of amplitude and phase angle with respect to depth. Figures ST-1 through ST-19 Indicate relations between logarithmic amplitude (log B) vs. depth, $x$, whereas F1gures SP-1 through SP-19 show relationsh1ps between the phase angle, $P$, and the depth, $x$, for the data obtained from 19 earth temperature stations.

It can be sald for all of 19 stations, except near the region of $x=0$, linear relationships between $\log B$ and $x$, and those between $P$ and $x$, are eminent from all of the ST and SP serfes of charts. The temperature 1rregular1ty near the ground surface can be expla1ned as follows :

(1) The earth surface region differs from the 1dealized heat conduction model of the previous discussion. The temperature pattern is complicated due to the fact that Irregular da1ly fluctuations of weather Influence the surface temperature.

(2) Temperature values are influenced by the time of observation unless the data are the average of the continuous hourly recording.

(3) The soll near the earth's surface 1s usually les homogeneous than at depth.

The density, water content, and composition vary within the region. 
The temperature data for 29 of the 63 stations covered a sufficient range of depths below the earth's surface to be suitable for evaluating thermal diffusivity, and earth surface temperature amplitude and phase angle by graphical methods. Those 29 earth temperature stations are identified by asterisks in Table 1. On each of the charts for those 29 stations, some of which have been illustrated in Figures ST-1 to 19, a straight edge was placed to fit the $\log B$ vs. depth data points by a visual inspection, such that the points at greater depths controlled the positions as well as the slopes of the straight edge. This visual technique was considered more appropriate for the analysis than a mathematical regression technique because most of the temperature data were concentrated near the shallow depth region where inconsistency with respect to the basic heat transfer theory is predominant due to heterogeneity of the material and diurnal effects. The visual technique did help to avoid obscuring the intrinsic linear relation of $\log B$ vs. X and $\mathrm{P}$ vs. $\mathrm{X}$ manifested in the deep earth temperature data by abundant shallow depth data. The earth surface temperature amplitude BO was then read at the intersecting point of the straight edge and the $x=0$ coordinate line. The slope of the straight edge thus determined was also used for calculating thermal diffusivity $D(B)$ by equation (6). Figures SP-1 through SP-19 show the plots of phase angles vs. depths calculated for the same 19 stations, the logarithmic amplitudes of which have been analyzed. A similar visual technique of finding the intercepts and slopes of the plots on $\log B$ vs. X was also employed on these phase angle-depth plots in determining the earth surface temperature phase angle and thermal diffusivity $D(P)$. 
The simplified theory demands that the diffusivities computed by the slope of $\log \mathrm{B}-\mathrm{x}$ relation and that of $\mathrm{P}-\mathrm{x}$ relation must agree. The thermal diffusivities computed by the two methods are summarized in Table 2 for eighteen selected stations where comprehensive information on earth temperature site characteristics was avallable. Fig. 3 graphically correlates the relationship between the two computed diffusivity values, $D(B)$ and $D(P)$. Of all the sets compared, eight showed an excellent agreement for the diffusivities computed by the amplitude method and phase lag method. A majority of the comparisons showed the diffusivity computed by the phase lag method to be lower than that computed by the amplitude method. No obvious correlation existed between the difference in the two thermal diffusivity values and earth temperature site characteristics, such as type of soil, elevation, earth surface, temperature level, or geographical location. Although it may be accidental, all three of the stations with bare earth cover showed very good agreement between the two diffusivities.

The difference between the thermal diffusivities computed by equations (6) and (7) may be attributable to the following conditions:

(1) Errors in assigning correct slopes for $\log \mathrm{B}-\mathrm{x}$ and $\mathrm{P}-\mathrm{x}$ curves due to the insufficient depth data as well as inconsistent temperature-depth data.

(2) Errors in calculating correct phase angle and amplitude from insufficient and fluctuating data. 


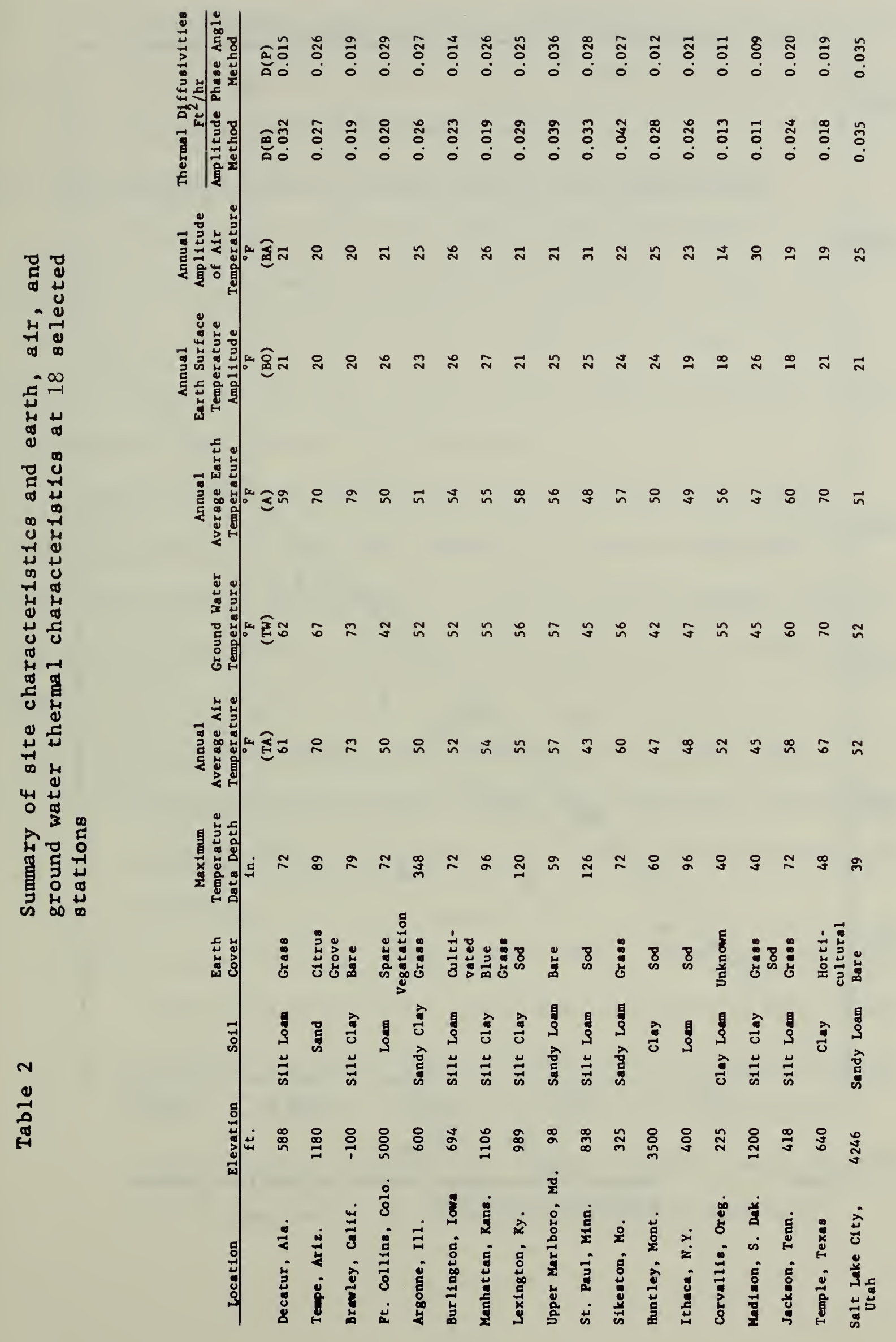




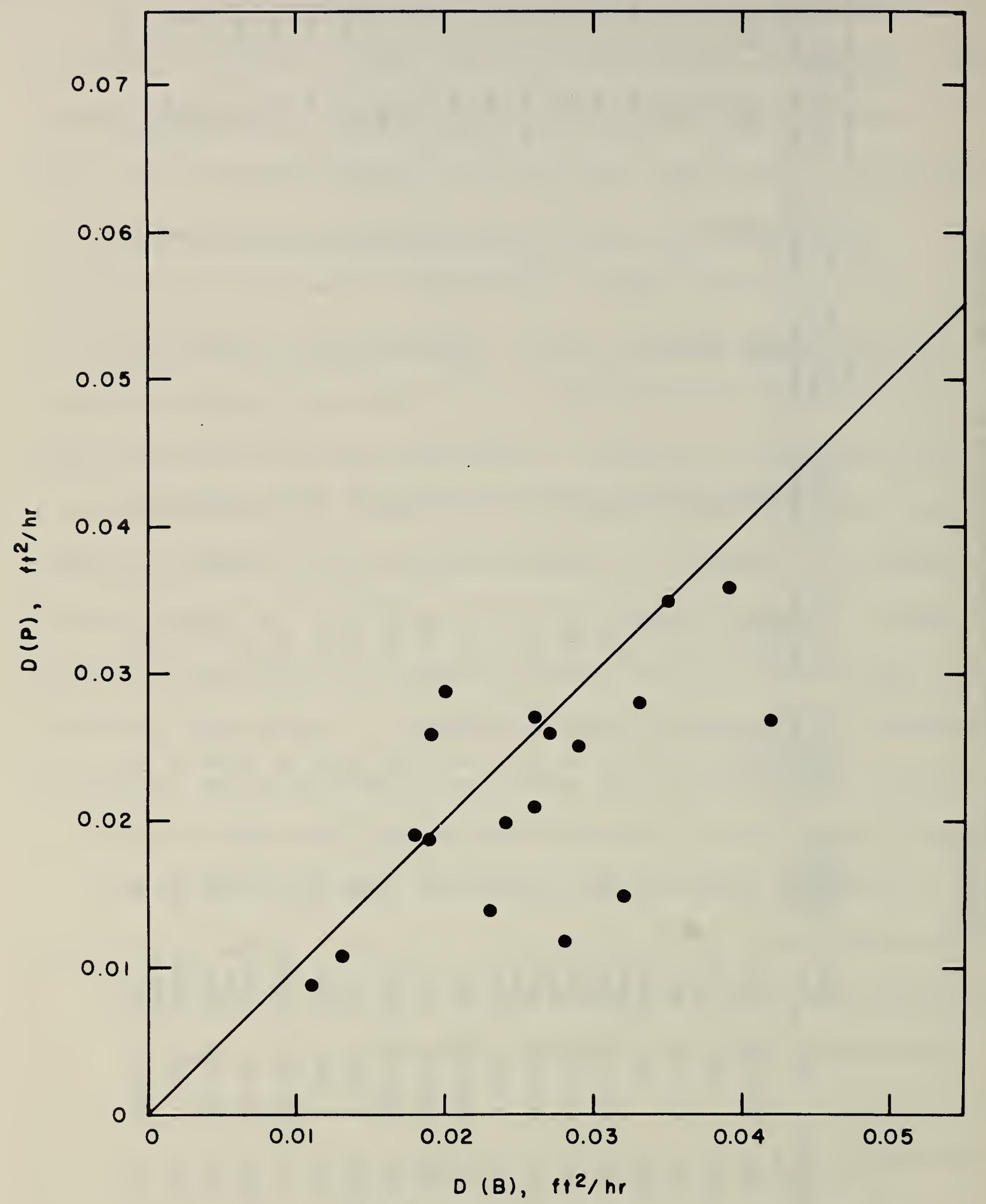

F1gure 3

Thermal diffusivities computed by amplitude method and phase angle method 
(3) Discrepancies from the ideal one-dimensional heat flow system due to the site characteristics of earth temperature stations of wh1ch the authors were unaware.

\section{Correlation of Earth, Alr, and Ground Water Temperatures}

According to Collins, $11 /$ the ground water temperature at a depth of $30 \mathrm{ft}$ to $60 \mathrm{ft}$ is very nearly equal to the annual average air temperature. The well-known Coll1ns' ground water temperature map was constructed on this basis, utilizing the annual average air temperature distribution of the 48 states.

Annual average air temperatures were collected from weather stations located near the earth temperature stations designated by solid dark and open dots In Fig. 1. The 11st of the weather stations and the data are shown in Table 3. Table 3 also lists the following data:

(1) The annual average a1r temperature, TA, and the annual amplitude of the monthly average air temperature cycle, BA, computed from the observed data for the indicated perlod of record.

(2) The least-squares constants, $\mathrm{TA}^{\prime}, \mathrm{BA}^{\prime}$, and $\mathrm{PA}^{\prime}$, for the annual average alr temperature, the annual amplitude of the monthly average air temperature cycle, and the phase angle of the air temperature cycle, respectively, for the climatological standard normals (1931-1960). These constants were determined in the same manner as those for the earth temperature. 


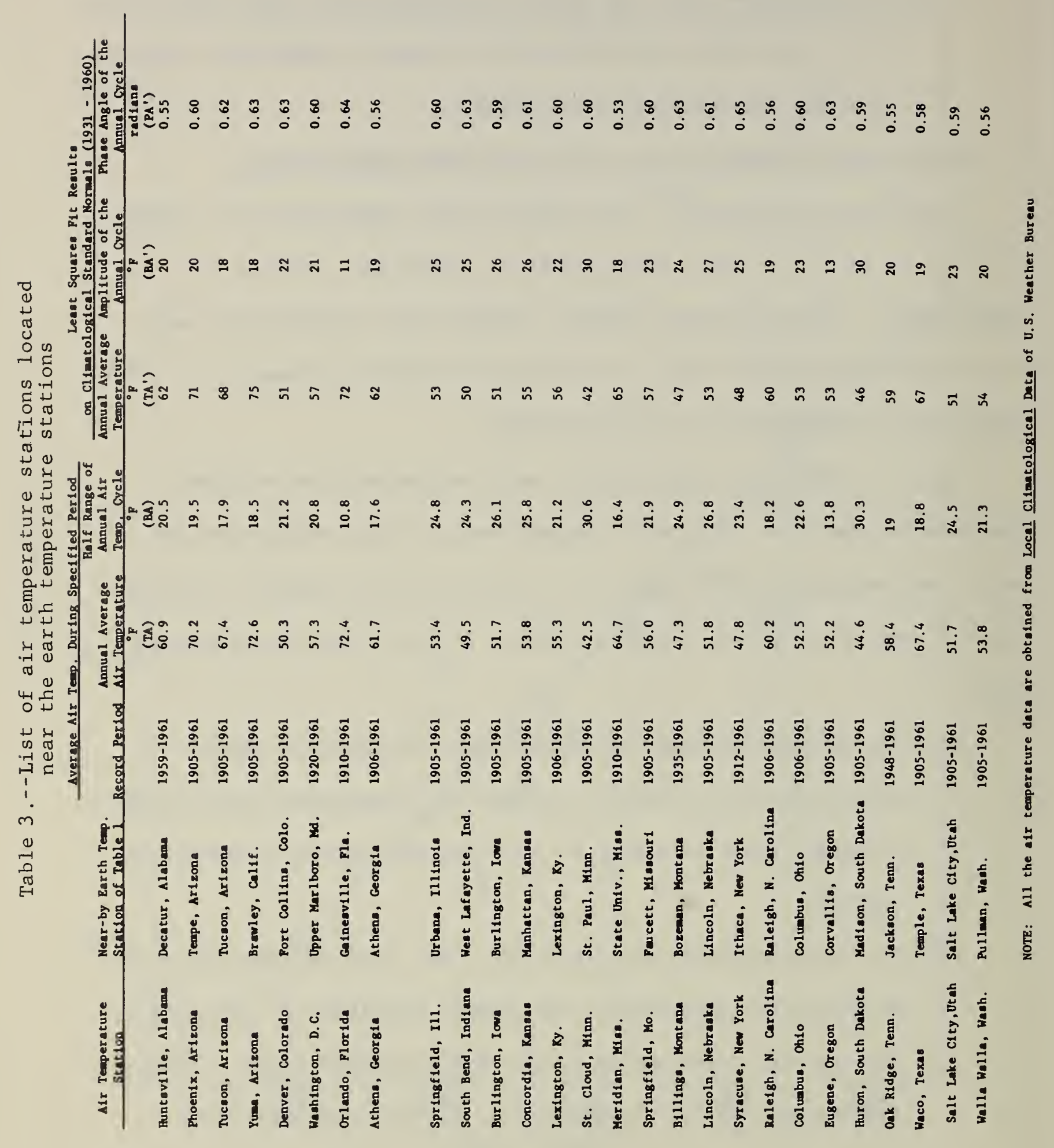


It can be seen from Table 3 that the values of $T A$ and $T A^{\prime}$ and those for $B A$ and $B A^{\prime}$ are nearly equal.

The values of annual average alr temperature TA and the amplitude of the monthly average alr temperature BA are superimposed on F1gures ST-1 through ST-19, whereas the alr temperature phase angle PA Is superimposed on F1gures SP-1 through SP-19.

Annual average earth temperature, A, and ground water temperature, $T W$, are plotted agalnst annual average alr temperature, TA, in F1g. 4 . The annual amplitude of monthly average air temperature, BA, 1s plotted in F1g. 5 against earth temperature amplitude at the surface BO. Although the annual average earth temperature, $A$, can be approximated elther by the annual average alr temperature, TA, or by Collins' water temperature, TW (from F1g. 1), the approximation of BO, the annual earth surface temperature amplitude from the annual amplitude of the monthly average air temperature, BA, is not too satisfactory, as shown by Fig. 5 and all of the figures in the ST serles. 


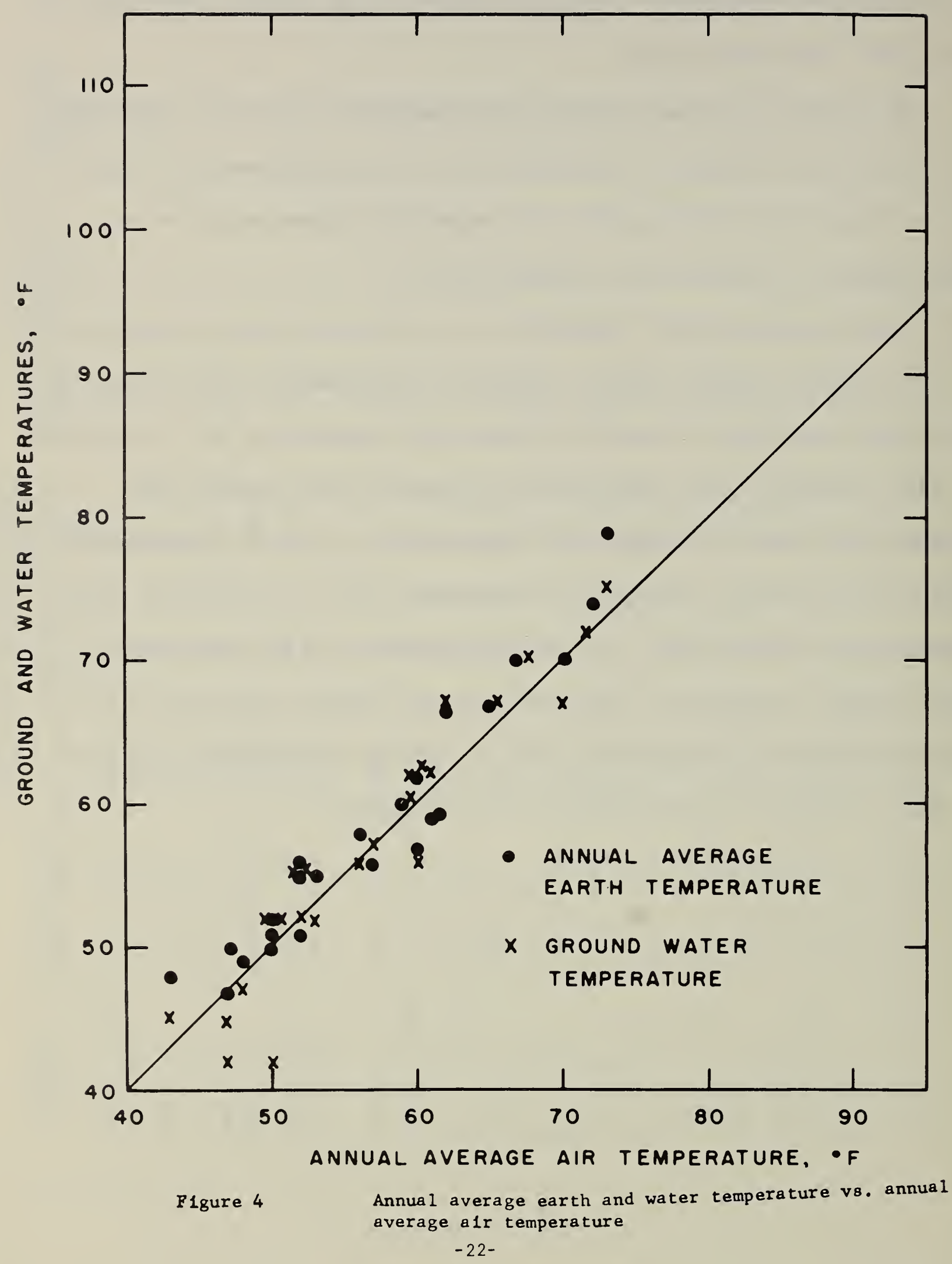


A close examination of Fig. 5 and Table 2 reveals the following interesting trend, however. The points of $\mathrm{BO}$ below the line of $\mathrm{BO}=\mathrm{BA}$ in Fig. 5, or the localities where $B O<B A$, represent inland cities such as Ithaca (New York), Sált Lake City (Utah), Madison (South Dakota), and St. Paul (Minnesota). In contrast, the points above the line of $\mathrm{BO}=\mathrm{BA}$ represent the near-coastal cities such as Gainesville (Florida), Corvallis (Oregon), Oxford (Mississippi), and Upper Marlboro (Maryland), with Fort Collins (Colorado) being an exception. A preliminary study for the Washington, D.C. area and for the Minneapolis (Minnesota) area has been made to compare the amplitudes and phase angles of annual cycles of monthly mean outdoor air temperatures and monthly mean solar radiation received on the flat surfaces for two cities, as shown in Fig. 6, with BO>BA in Washington, D.C. and BO<BA in Minneapolis. Fig. 6 reveals that the Minneapolis area receives slightly more solar radiation during the summer months of July and August and slightly less from October to December than Washington, D.C., and has considerably lower monthly average outdoor air temperature than the Washington, D.C. area throughout the year. Since earth temperature is dependent on both the heat exchange with outdoor air and solar radiation, the relation between BO and BA cannot be explained adequately without including solar effects. 


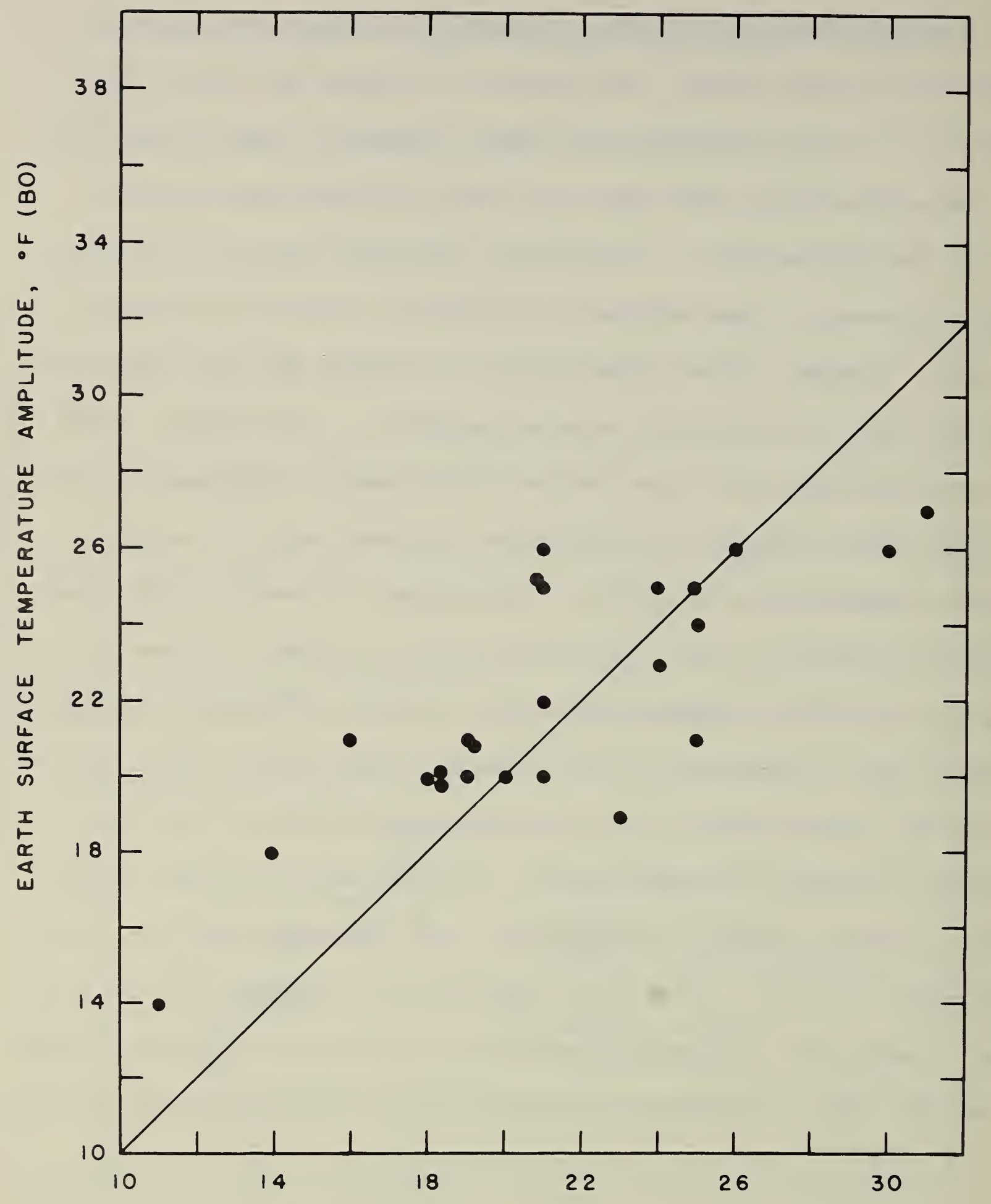

AMPLITUDE OF MONTHLY AVERAGE AIR TEMPERATURE, (BA), ${ }^{\circ} \mathrm{F}$ P1gure 5 Annual amplitude of monthly average air temperature vs. annual earth surface temperature amplitude 

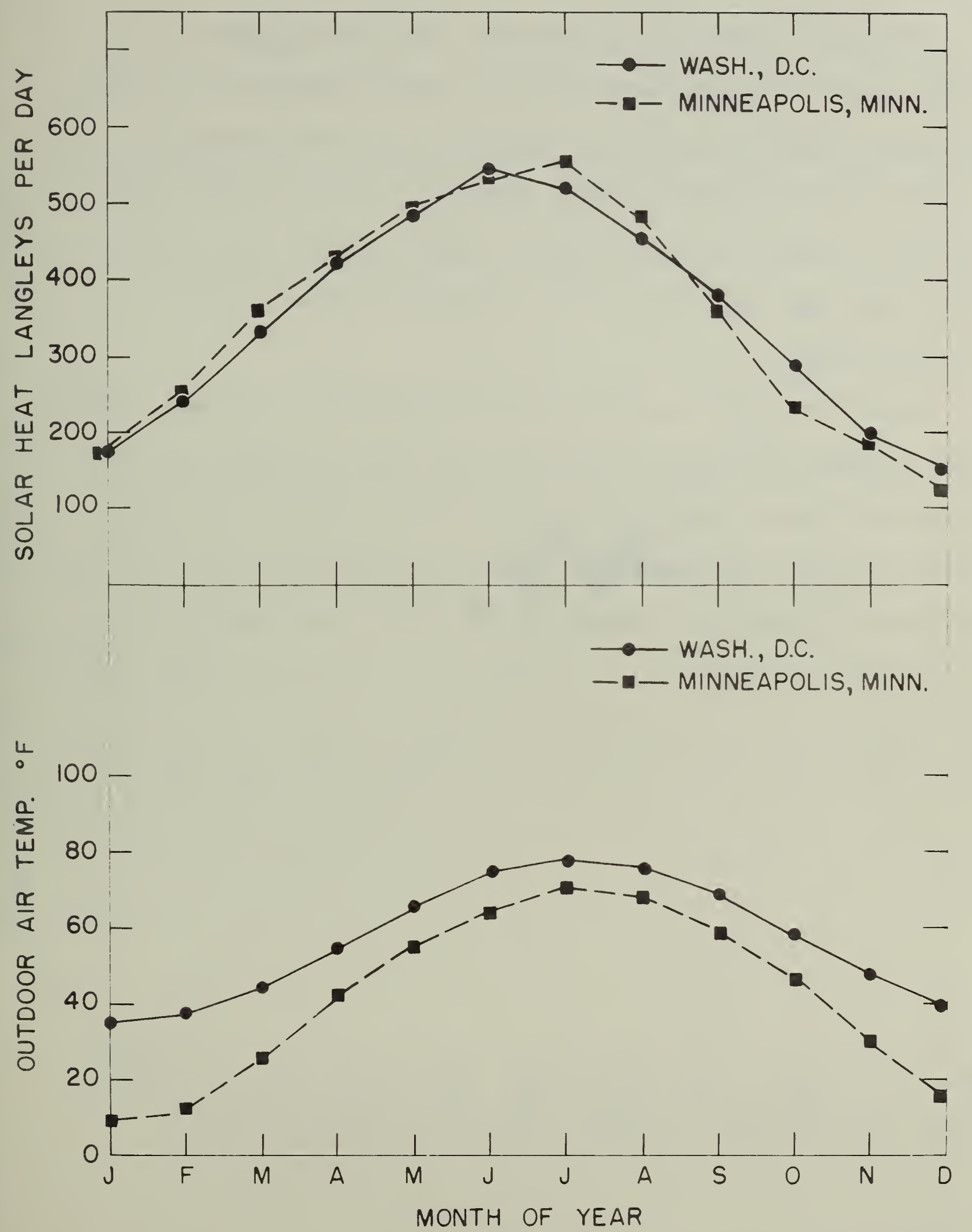

F1gure 6

Annual cycles of monthly average dally solar

Insolation and monthly average outdoor alr temperature

for Washington, D. C. and Minneapol1s, Minnesota 
The phase angles of air temperature cycle PA and those of the earth surface temperatures PO are also compared graphically in Fig. 7 . The phase angles of annual air temperature cycles are concentrated in a narrow band of $0.6 \pm 0.05$ radians regardless of the locallty, whereas the phase angles of the earth surface temperature are scattered in a much wider range than those of alr temperature cycles as can be observed in Fig. 7 .

Analytical studies such as made by Lettan 15 / for the earth surface heat exchange with respect to outdoor a1r, solar radiation, sky radiation, evaporation, and nighttime outgoing radiation may give direction to the computation or prediction of $\mathrm{BO}$ and $\mathrm{PO}$ from the data for BA and PA which are readily available from local weather records. 


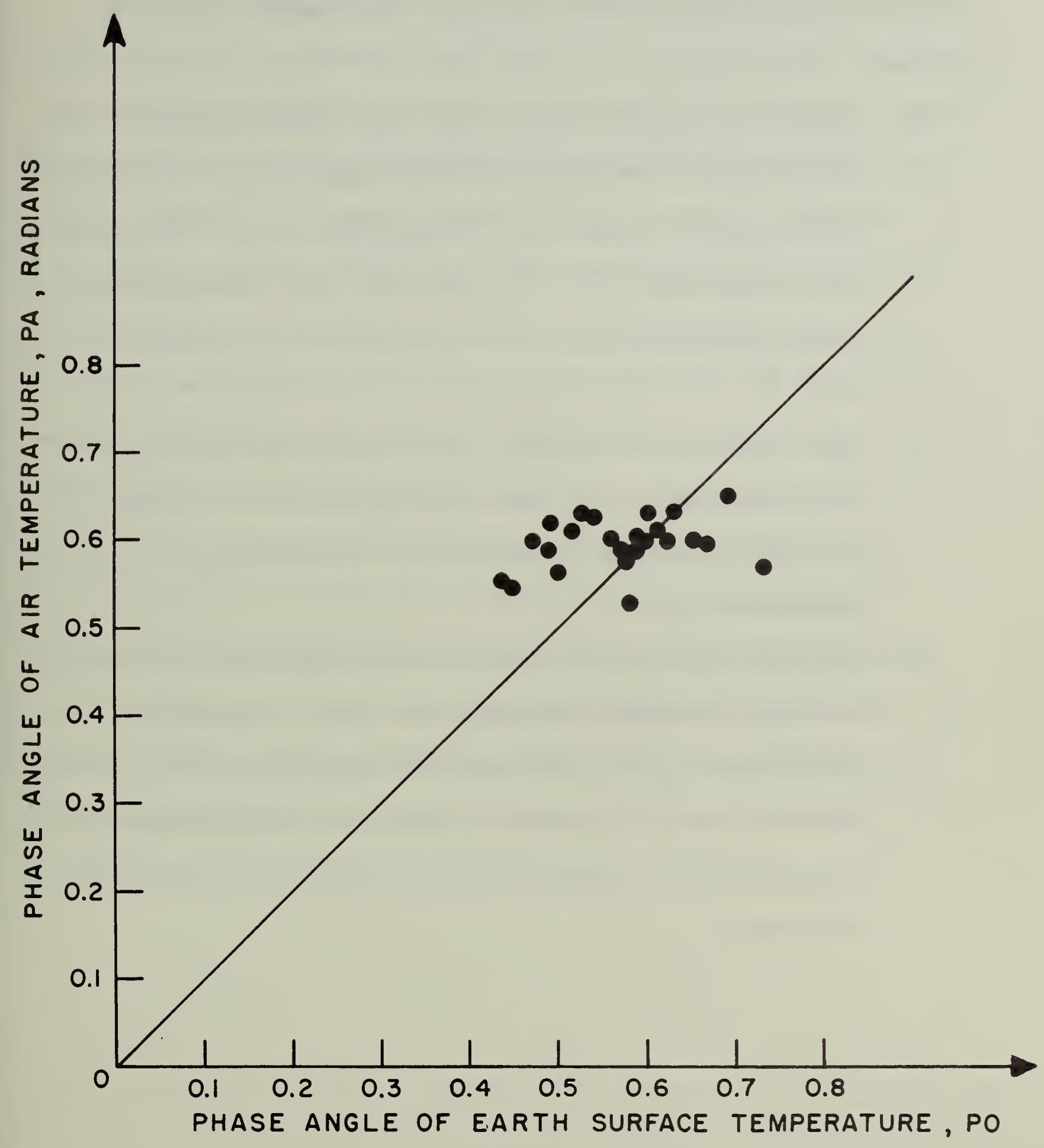

F1gure 7

Phase angle relations between the annual cycles of monthly average alr and earth surface temperatures 
The following general conclusions can be drawn from the foregoing analysis of the data from several selected earth and air temperature stations:

(1) Except near mountain ranges there is a strong tendency toward equality among the annual average air temperatures, TA, the annual average earth temperature, A, and deep ground water temperature, TW. In other words, the annual average ground temperature, A, can be reasonably well estimated by TA or TW.

(2) With somewhat less accuracy, earth temperature amplitude at the undisturbed surface (BO) can be approximated by the amplitude of the annual cycle of monthly average air temperature (BA)。

(3) The phase angles of the earth surface temperature cycles do not show a definite correlation with that of annual air temperature cycles. The annual air temperature cycles of various cities in the United States are all approximately in phase with the minimum occurring about at the beginning of February. 


\section{Calculations of Earth Temperatures}

Having developed values for annual average earth temperature, A, the earth surface temperature amplitude, BO, and phase angle, $P O$, by least-squares technique from the observed data, and knowing the thermal diffusivity, D, of the soil which has been calculated from the leastsquares constants at several depths, it was possible to calculate the earth temperature by equation (3). Such calculations were performed with the data of Tables ST-1 through 63 using the arithmetic average of the thermal diffusivities determined by amplitude and phase angle methods. The lower portion of ST tables shows the calculated temperatures for all of the observed depths. The calculations were performed with the use of equation (3) by employing the parameter values indicated at the bottom of the ST tables. The agreement between the calculated and the observed are generally satisfactory, in most instances, particularly at greater depths. The probable reasons for the greater discrepancy between the calculated and the observed earth temperature near the earth surface are described in Section 5. 
In many instances, it may be desirable to have a rough approximation of undisturbed earth temperature at a given depth or at several depths where all or some of the constants, A, BO, and PO, and the thermal diffusivity are unknown. As indicated in the previous section, A can be closely approximated by the annual average air temperatures TA, but $\mathrm{BO}$ and $\mathrm{PO}$ are not closely predictable from air temperature amplitude BA, and phase angle PA. The thermal diffusivities may be determined for a given soil by laboratory test or may be computed by handbook values of thermal conductivity, density and specific heat if the type of soil and 1ts molsture content are known.

The STA tables show computed monthly earth temperatures for all of the 63 earth temperature stations, for depths of 2, 4, 6, 8, and $10 \mathrm{ft}$, using temperature characteristics, such as $\mathrm{A}, \mathrm{BO}$, and $\mathrm{PO}$, taken from the corresponding ST table when available, or otherwise approximated by the air temperature data, and for an arbitrarily chosen thermal diffusivity of $0.025 \mathrm{ft}^{2} / \mathrm{hr}$, which is an approximate median of all of the thermal diffusivities derived from the observed earth temperature data. In order to examine the effect of thermal diffusivities other than $0.025 \mathrm{ft}^{2} / \mathrm{hr}$ upon the earth temperature, the STA tables also include calculated August earth temperatures for the same depths and same values of $A, B O$ and $P O$ but with diffusivities of $0.01,0.02,0.03$, and $0.04 \mathrm{ft}^{2} / \mathrm{hr}$ in addition to $0.025 \mathrm{ft}^{2} / \mathrm{hr}$. 


\section{Integrated Average Temperature of Upper 10-ft Stratum}

Although the earth temperature distribution with respect to depth Is important for the accurate numerical calculation of heat transfer

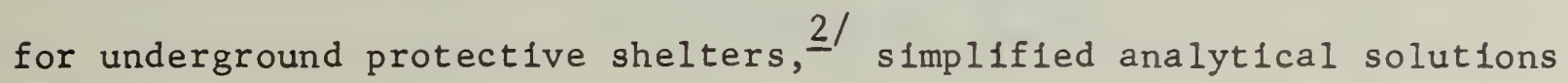
currently ava1lable $\frac{16,17 /}{2 e q u 1 r e}$ only an average earth temperature surrounding the shelter at the time of entry. This simplification Is employed princlpally because the heat conduction problem becomes very complicated for complex Initial temperature conditions.

By integrating equation (3) with respect to $x$ from the surface to depth $L$, an average temperature $\bar{t}_{L}$ can be obtalned for this range of depths as follows:

$$
\begin{aligned}
\bar{t}_{L} & =\frac{1}{L} \int_{0}^{L}\left\{A-B O e^{-\sqrt{\frac{\pi}{D T}} x} \cos \left(\frac{2 \pi \theta}{T}-P O-\sqrt{\frac{\pi}{D T}} x\right)\right\} d x \\
& =A+\frac{B O}{2 \sqrt{\frac{\pi}{D T}}} L\left(e ^ { - \sqrt { \frac { \pi } { D T } } L } \left\{\sin \left(\frac{2 \pi \theta}{T}-P O-\sqrt{\frac{\pi}{D T}} L\right)\right.\right. \\
& \left.\left.+\cos \left(\frac{2 \pi \theta}{T}-P O-\sqrt{\frac{\pi}{D T}} L\right)\right\}-\left\{\sin \left(\frac{2 \pi \theta}{T}-P O\right)+\cos \left(\frac{2 \pi \theta}{T}-P O\right)\right\}\right]
\end{aligned}
$$


By denoting

$$
\text { r } \begin{aligned}
\beta & =\sqrt{\frac{\pi}{D T}} L \\
\text { and } \quad \quad \quad \phi & =\sqrt{\frac{e^{-2 \beta}-2 \cos \beta e^{-\beta}+1}{2 \beta^{2}}} \\
& \tan ^{-1} \frac{1-e^{-\beta}(\cos \beta+\sin \beta)}{1-e^{-\beta}(\cos \beta-\sin \beta)},
\end{aligned}
$$

equation (8) can be reduced to the following expression

$$
\frac{\bar{E}_{L}-A}{B O}=-\Gamma \cos \left(\frac{2 \pi \theta}{T}-P O-\emptyset\right)
$$

The integrated average $\bar{t}_{I}$ for $0 \leq x \leq I$ can then simply be evaluated by knowing $\beta$ in addition to $A, B O$ and $P O$, since $\Gamma$ and $\varphi$ are functions of $\beta$ alone. Fig. 8 shows $\Gamma$ and $\varphi$ as a function of $\beta$ in order to assist in making the calculation of the integrated average temperature. Fig. 9 shows the computed August and February earth temperature plotted against depth for Lexington, Kentucky. The integrated average values are also 1llustrated at 10-ft, 16-ft, and 20-ft depths.

Contemporary underground fallout shelters have approximately 3-ft earth cover over the roof, and their cefling helghts are usually in the range of $7 \mathrm{ft}$ to $10 \mathrm{ft}$. The temperature of earth surrounding the shelter is usually affected Iittle during the 14-day occupancy perlod, beyond a region that extends outwardly $5 \mathrm{ft}$ from the shelter walls including the floor. $2 /$ 
అ

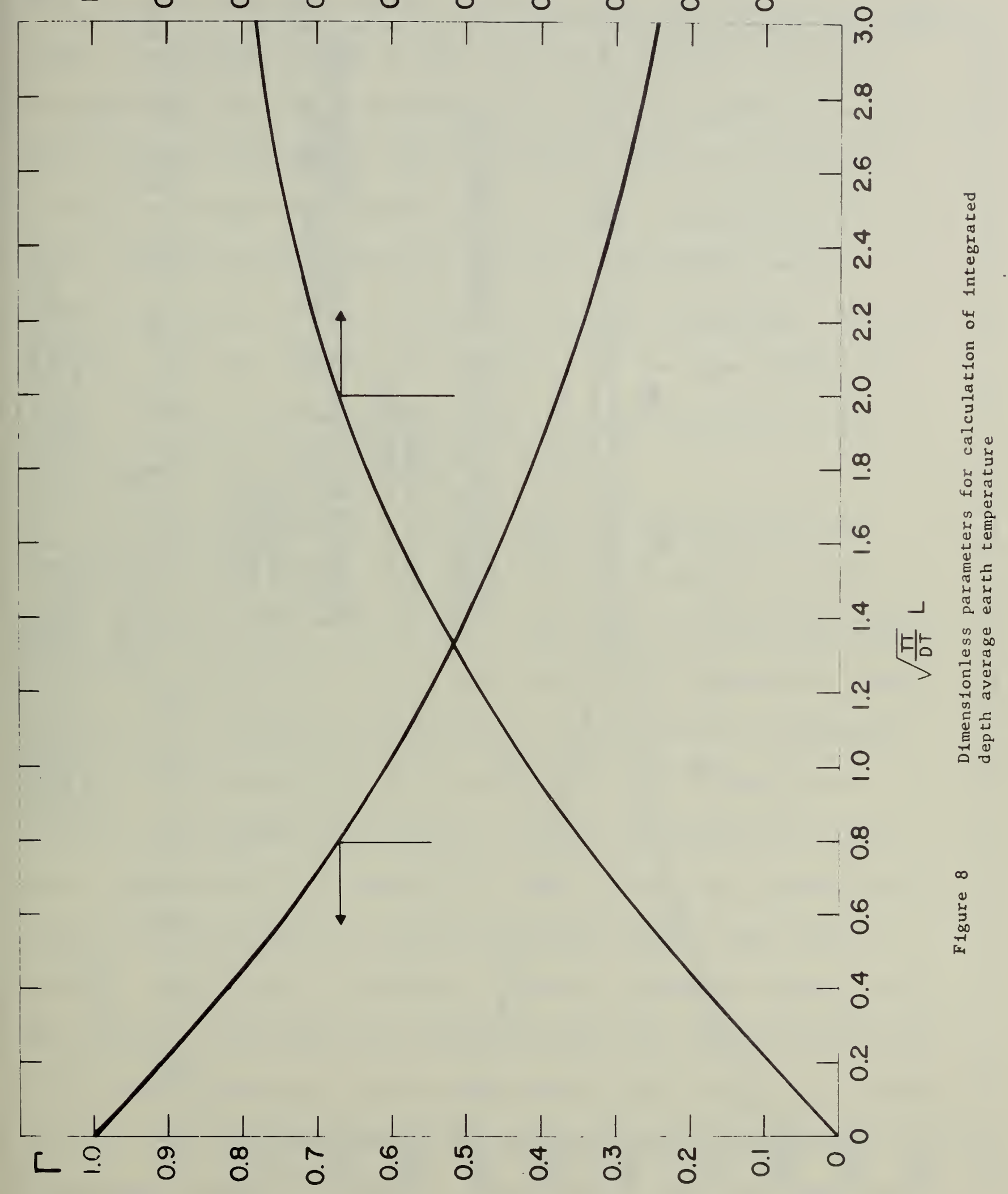




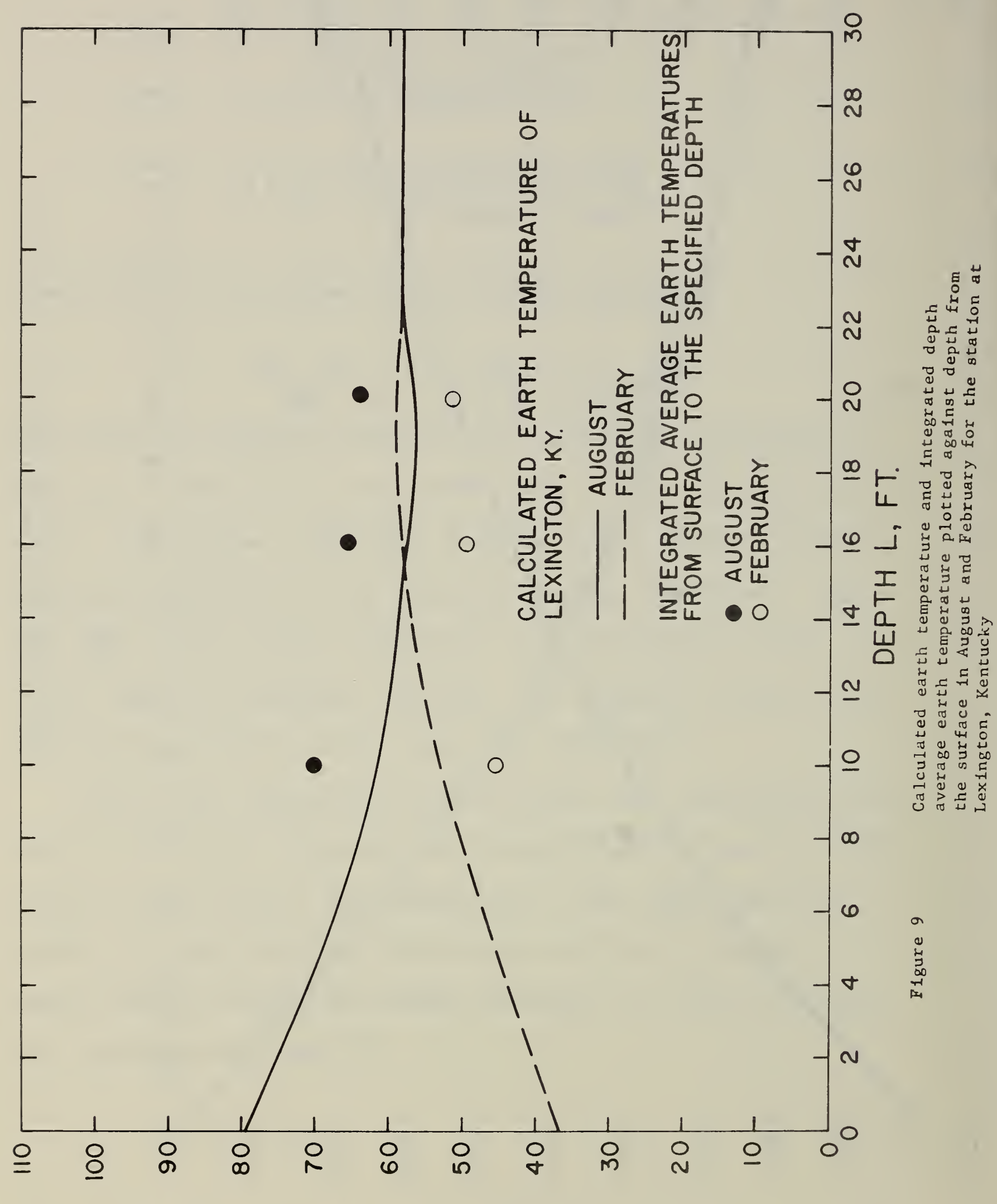

S $\exists y \cap \perp \forall y \exists d W \exists \perp \quad H \perp \forall \forall \exists \quad 0 \exists \perp \forall า ก \supset 7 \forall ว$ 
Thus, the maximum depth to be considered for contemporary shelter heat conduction analysis is approximately $20 \mathrm{ft}$ from the surface. The earth temperatures studied in this report are, however, the monthly averages which will be considerably lower during the summer than the daily averages particularly near the surface. Thus, the integrated average temperature from surface to 10-ft depth, instead of 20-ft depth, is arbitrarily selected to represent a reasonable earth temperature criterion for protective shelter heat conduction. F1g. 9, however, shows that the average temperature of the upper 20 feet of earth is about 6 degrees lower than for the upper 10 feet of earth in the month of August for Lexington, Kentucky.

In studying summer shelter environment in the United States, integrated average August earth temperatures from surface to 10-ft depth are, therefore, of the greatest importance. On the other hand, it is also important to know the lower end of earth temperature cycle for the winter occupation of shelters, in which case the integrated February earth temperatures from the surface to 10-ft depth may be valuable. The maximum and minimum values of the integrated average earth temperatures of the upper 10-ft layer of earth are probably most useful from the standpoint of the underground shelter heat transfer analysis. Table 4 was, therefore, prepared to summarize annual maxima and minima of calculated 10-ft depth average earth temperatures for all of the earth temperature stations analyzed in this paper. Also listed in Table 4 are the annual maxima and minima of monthly average air temperatures observed at weather stations nearby the earth temperature 
stations. The annual maxima and minima of the monthly average air temperature, however, occur for months of July and January, respectively, which are both one month ahead of the maxima and minima of earth temperatures. Although most of the air temperature data are based upon thirty years' norm (1921-1950), the earth temperature values in Table 4 are derived from records of only a few years' duration. Thus a good correlation between the annual maximum of the average earth temperature to maximum air temperature, or that between the minima, cannot be expected from these data.

Since all of the monthly earth temperatures in Table 4 and in Tables STA 1-63 have been calculated for the thermal diffusivity of $0.025 \mathrm{ft}^{3} / \mathrm{hr}$, the computations were also made of the August earth temperature at five different thermal diffusivities for the purpose of comparison as shown in the lower part of Tables STA 1-63. It is interesting to note that the integrated averages of earth temperature for the upper $10 \mathrm{ft}$ of earth are not greatly affected by the variation of earth thermal diffusivities. A diffusivity change from $0.02 \mathrm{ft}^{2} / \mathrm{hr}$ to $0.04 \mathrm{ft}^{2} / \mathrm{hr}$, for instance, affects this integrated average earth temperature by approximately $2^{\circ} \mathrm{F}$, whereas the same factor of 2 change in thermal diffusivity from $0.01 \mathrm{ft}^{2} / \mathrm{hr}$ to $0.02 \mathrm{ft}^{2} / \mathrm{hr}$ affects the integrated average temperature by $3^{\circ} \mathrm{F}$ to $4^{\circ} \mathrm{F}$. Unless the soil is extremely dry or highly insulative, however, the in-situ earth thermal diffusivity is generally higher than $0.015 \mathrm{ft}^{2} / \mathrm{hr}$, as seen from the values on Tables STA $1-63$. 
Annual maxima and minima of a1r temperature and Integrated average earth temperature from surface to 10-ft depth

ST No.

Auburn, Ala.

Decatur, Ala.

Tempe, Ariz.

Tucson, Ariz.

Brawley, Calif.

Davis, Calif.

Ft. Collins, Colo.

Ft, Collins, Colo.

Ft. Collins, Colo.

Gainesville, Fla.

Athens, Ga.

Tifton, $\mathrm{Ga}$.

Moscow, Idaho

Argonne, III.

Lemont, I11.

Urbana, I11.

Urbana, I11.

West Lafayette, Ind.

Burlington, Iowa

Manhattan, Kans.

Lexington, $\mathrm{Ky}$.

Lexington, Ky.

Upper Marlboro, Md.

East Lansing, Mich.

East Lansing, Mich.

East Lansing, Mich.

East Lansing, Mich.

East Lansing, Mich

St. Paul, Minn.

State Univ., Miss.

Faucett, Mo.

Kansas City, Mo.

Sikeston, Mo.

Bozeman, Mont.

Bozeman, Mont.

Huntley, Mont.

Lincoln, Nebr.

Lincoln, Nebr.

Norfolk, Nebr.

New Brunswick, N.J.

Ithaca, N.Y.

Ithaca, N.Y.

Raleigh, N. Car

Columbus, Ohio

Coshocton, Ohio

Barnsda11, Okla.

Hominy, Okla.

Lake Hefner, Okla.

Pawhuska, Okla.

Ottawa, Ont.

Corval1is, Oreg.

Pendleton, Oreg.

Calhoun, S. Car.

Union, S. Car.

Madison, S. D.

Jackson, Tenn.

Temple, Texas

Temple, Texas

Salt Lake City, Utah

Burlington, Vt.

Pullman, Wash.

Pullman, Wash.

Seattle, Wash.
Huntsville, Ala.d

Phoenix, Ariz.

Tucson, Ariz.

Yuma, Ariz.

Sacramento, Calif.

Denver, Colo.

Denver, Colo.

Denver, Colo.

Orlando, Fla

Athens, $\mathrm{Ga}$.

Albany, Ga.

Idaho Falls, Idahoe

Chicago, Ill.

Chicago, Ill.

Springfield, I11.

Springfield, I11.

South Bend, Ind.

Burlington, Iowac

Concordia, Kans.

Lexington, $\mathrm{Ky}$.

Lexington, Ky.

Washington, D. C.

East Lansing, Mich c 77

East Lansing, Mich.c 71

East Lansing, Mich. ${ }^{c} 71$

East Lansing, Mich. ${ }^{\mathrm{C}} 71$

East Lansing, Mich, ${ }^{\mathrm{C}} 71$

Minneapolis, Minn.

Meridian, Miss.

Springfield, Mo.

Kansas City, Mo.

Springfield, Mo.

Billings, Mont.

Billings, Mont.

Billings, Mont.

Lincoln, Nebr.

Lincoln, Nebr.

Norfolk, Nebr.

Newark, N.J.

Syracuse, N.Y.

Syracuse, N.Y.

Raleigh, N. Car.

Columbus, Ohio

Columbus, Ohio

Oklahoma City, Okla.

Oklahoma City, Okla.

Oklahoma City, Okla.

Oklahoma City, Okla.

Ot tawa, Ont.

Eugene, Oreg.

Pendleton, Oreg.

Columbia, S. Car.

Columbia, S. Car.

Huron, S. D.c

Oak Ridge, Tenn.

Waco, Texas

Waco, Texas

Salt Lake City, Utah

Burlington, Vt.

Walla Walla, Wash.

Walla Walla, Wash.c

Seattle, Wash.

$\frac{\text { Maximum }}{\underline{\text { Air a }} \text { Earthb }}$

\section{$\frac{\text { Minimum }}{\underline{\text { Air }} \mathrm{a} \quad \text { Earth }}$}

$\begin{array}{llll}81 & 74 & 49 & 56\end{array}$

$\begin{array}{llll}81 & 71 & 43 & 48 \\ 90 & 81 & 50 & 59\end{array}$

$\begin{array}{llll}86 & 85 & 50 & 65\end{array}$

$95 \quad 90 \quad 55 \quad 68$

$\begin{array}{llll}75 & 76 & 44 & 56\end{array}$

$\begin{array}{llll}72 & 63 & 29 & 37\end{array}$

$\begin{array}{llll}72 & 63 & 29 & 37\end{array}$

$\begin{array}{llll}82 & 84 & 29 & 36 \\ 81 & 77 & 62 & 69\end{array}$

$\begin{array}{llll}81 & 77 & 45 & 57\end{array}$

$83 \quad 80 \quad 51 \quad 62$

$\begin{array}{llll}69 & 57 & 16 & 37\end{array}$

$\begin{array}{llll}75 & 64 & 25 & 38 \\ 75 & 65 & 25 & 39\end{array}$

$\begin{array}{llll}76 & 67 & 27 & 39\end{array}$

$\begin{array}{llll}76 & 68 & 27 & 42\end{array}$

$\begin{array}{llll}71 & 66 & 25 & 38 \\ 77 & 71 & 24 & 38\end{array}$

$\begin{array}{llll}80 & 69 & 28 & 41\end{array}$

Remarks :

a. Unless otherwise stated, all the air temperature data are thirty year norm (1921-1950) airport data published in Technical Paper No. 31, U.S. Weather Bureau Publication 1956.

b. Earth temperatures shown are integrated average from surface to $10 \mathrm{ft}$ depth calculated by observed earth temperature characteristics, each as average, amplitude and phase angle and earth thermal diffusivity of $0.025 \mathrm{ft}^{2} / \mathrm{hr}$ for most of the stations.

c. City office air temperature data instead of airport data.

d. Climatological Standard normals of 1931-1960 instead of 1921-1950 norm.

e. Exact location of air temperature station unknown.

f. Air temperature data from Penrod?/ 
Carter $18 /$ shows extensive field records of temperature, moisture, and thermal properties of seven earth temperature and moisture measurement stations in the Tennessee Valley Area. Carter's data show that the field thermal diffusivities for various types of soil ranged from $0.016 \mathrm{ft}^{2} / \mathrm{hr}$ of clay to $0.045 \mathrm{ft}^{2} / \mathrm{hr}$ of clay-sand with the majority being in the neighborhodd of $0.025 \mathrm{ft}^{2} / \mathrm{hr}$, with the moisture content of from 20 percent to 40 percent.

\section{Conclusions}

Extensive analyses have been made on earth temperature data from 63 stations located in fifty different areas throughout the United States. Annual cycles of monthly average earth temperatures have been used to study and correlate their annual averages, amplitudes, phase angles and thermal diffusivities.

It has been found that simplified heat conduction theory based upon the simple harmonic presentation of earth temperature provides an acceptable approximation of the monthly average earth temperatures at various depths. The thermal diffusivities computed by the amplitude and phase lag methods are in reasonably good agreement for most of the earth temperature data. The thermal diffusivities computed in these analyses from the data for Lexington, Kentucky, and Argonne, I11inois, are compatible with those computed by Penrod-8/and Carson, $10 /$ respectively. 
The tabulated data for the observed monthly average earth temperature for different localities can serve as a general guide in estimating earth temperatures in the vicinities of those particular stations. A monthly average earth temperature at a given point can be calculated by simple equation (3) if annual average earth temperature (AO), amplitude and phase angle of the ground surface temperature (BO), and (PO), and the thermal diffusivity are previously known. The influence of the thermal diffusivity upon the integrated average earth temperature to a depth of $10 \mathrm{ft}$ is not too critical in that uncertainty by a factor of two in the diffusivity from 0.02 to $0.04 \mathrm{ft}^{2} / \mathrm{hr}$ produces only about $2^{\circ} \mathrm{F}$ change in average temperature for the month of August.

This analysis indicates that the annual average earth temperature in the range studied is invariant with respect to depth and is very closely approximated by the annual average air temperature or by Collin's ground water temperature map, shown in Fig. 1.

The temperature data analyzed in this report are, however, not extensive enough to provide a good statistical or functional correlation of ground surface temperature amplitude and the phase lag with respect to climatological and site characteristics of the earth temperature stations. 
An adequate analysis of heat transfer in underground structures requires information on earth temperature distribution from the surface to a depth of about $10 \mathrm{ft}$. Very few of the data compiled in this report cover more than a 6-foot depth from the surface. The extensive calculation of earth temperatures for depths of $2,4,6,8$ and $10 \mathrm{ft}$ and the integrated depth average for all of the earth temperature stations employed in this paper have been based on the temperature characteristics derived from the observed monthly average earth temperatures and selected thermal diffusivity of $0.025 \mathrm{ft}^{2} / \mathrm{hr}$. Annual maxima and minima of the upper 10-ft earth temperature are summarized in Table 6 of this paper. Unt11 more comprehensive and substantial data are made available in the future, the values of Table 6 may serve as tentative design criteria for analyzing the heat transfer of underground structures. 
10. Recommendations:

Although a considerable amount of earth temperature data have been compiled during this study, deep earth temperature data (to the depth of more than $3 \mathrm{ft}$ ) are conspicuously missing from most of the southern and western states as seen from Fig. 1. Establishment of new earth temperature stations in these regions is clearly needed.

The following suggestions should be considered in selecting earth temperature stations for future studies related to the design requirements for shelters:

(1) Earth temperature sites should be close to local weather stations where simultaneous observations of air temperature, rainfall, solar radiation and other pertinent records are kept.

(2) Earth should be bare or covered with short grass. If possible, two sites should be chosen at the same relative location; one grass-covered and one bare.

(3) Soil composition and dry density should be determined and the moisture content should be checked at intervals during the period of study.

(4) Enough observations should be taken during the day to obtain a good daily average temperature, particularly at depths less than $3 \mathrm{ft}$.

(5) At least three years of continuous data are needed.

(6) Temperatures should be observed at five or more depths, at least three of which should be in excess of $5 \mathrm{ft}$. 


\section{Appendix: Discussion of Least-Squares Technique}

Numerous papers are available with respect to the calculation of earth temperature. Recent papers of Penrod, $\underline{8,9 /}$ Carson, $\underline{10 /}$ and Langbein $11 /$ are, however, noteworthy from the standpoint of their distinctly different approaches. Penrod $9 /$ developed equations of a single harmonic term to describe the annual ground temperature cycles of Lexington, Kentucky, and Ottawa, Ontario. Carson $10 /$ described the hourly and monthly earth temperatures of Argonne, Illinois, by a Fourier series of six harmonics.

Langbein $11 /$ has shown a method of predicting the earth temperature at a point as a weighted function of antecedent temperatures at the ground surface using the probability integral function.

Examination of Carson's work10/ reveals that as much as 99.8 and as little as $93 \%$ of the total variance of the annual cycle are accounted for by the first harmonic. In this paper, therefore, equations of simple harmonics of the following type have been developed to describe the monthly earth temperature at several depths using a least-squares fitting technique:

$$
t=A-B \cos (\omega \theta-P)
$$


where $t=$ monthly average ground temperature at a point for a given time

$\mathrm{A}=$ annual average earth temperature, ${ }^{\circ} \mathrm{F}$

$B=$ annual amplitude of the earth temperature, ${ }^{\circ} \mathrm{F}$, at a given depth

$\omega=$ angular velocity corresponding to the annual cycle, radian/hr

$\theta=$ elapsed time from January 1 , hr

$\mathrm{P}=$ phase angle of the earth temperature at a given depth, radian The values of $A, B$, and $P$ have been so determined in this analysis that the following least-squares relationship has been satisfled:

$$
S=\sum_{K=1}^{N}\left(t-t_{K}\right)^{2} \rightarrow \text { mIn Imum }
$$

where $t_{K}=$ observed earth temperature at a given point and for a given time

and $\mathrm{N}=$ total number of observed data at a given point

The standard deviation of the least-squares fit values from the observed temperatures is designated and calculated by the following relation:

$$
S D=\sqrt{\frac{S}{N-3}}
$$


Any time series, such as earth temperature data, consisting of a finite number of equally spaced data points can be completely accounted for by a finite number of sine and cosine terms in a Fourier Analysis. This was done exactly by Carson $10 /$ for the analysis of a monthly average and daily average earth temperature series consisting, respectively, of 12 and 24 equally spaced data points in Argonne, I11inois. An examination of Carson's results indicates that the higher harmonics of Fourier series have a very minor contribution to the description of the annual cycle for all the depths. It should be noted, however, that the higher harmonics show a considerable influence upon the diurnal earth temperature equations for all the depths, regardless of the time of year. Since the annual variation of the monthly average temperature is of a greater interest than the diurnal variation for the purpose of shelter design, the use of the higher harmonics is not warranted. It is hypothesized therewith that any deviation of monthly average soil temperature data from simple harmonic time function is statistical rather than functional. And it is also assumed that the constants $A, B$, and $P$ of equation $A-1$ for a given temperature point are independent of the year when the data are taken; namely, they are the intrinsic properties of the particular point. 
One of the purposes of this study is then the determination of $A$, $B$, and $P$ at several depths of earth for many soll stations throughout the United States. Compared with the technique employed by Penrod 9 / for the determination of $B$ and $P$, the least squares technique developed here is fundamentally more straightforward, simpler, and requires no human fudgment. The method is better sulted for a machine calculation. The comparison of the least squares technique with the Fourier analysis or harmonic analysis technique is most interesting. Such discussion is, however, beyond the scope of this report except that the Fourier analysis uses the earth temperature data as time dependent variables (single valued), whereas the least squares technique uses the earth temperature data as time dependent variates which are random in nature and multi-valued.

The Langbein technique $14 /$ is of different nature and beyond the scope of this discussion. 
Using the symbols Iisted in the Nomenclature section of this report, a quantity, $S$, is defined by relation A-2 such that

$$
S=\sum_{K=1}^{N}\left(t_{K}-A+B \cos \left(\omega_{K}-P\right)\right)^{2} \quad A-4
$$

where $\mathrm{N}$ does not have to be 12 or its multiples. $\mathrm{A}, \mathrm{B}$, and $\mathrm{P}$ are determined by solving simultaneously the following equations

$$
\begin{aligned}
& \frac{\partial S}{\partial A}=0 \\
& \frac{\partial S}{\partial B}=0 \\
& \frac{\partial S}{\partial P}=0
\end{aligned}
$$

The following notations are now introduced:

$$
\begin{aligned}
& \alpha_{0}=\Sigma t_{K} \\
& \alpha_{1}=\Sigma t_{K} \cos \omega_{K} \\
& \alpha_{2}=\Sigma t_{K} \sin \omega_{K} \\
& \xi_{1}=\Sigma \cos \omega_{K} \\
& \xi_{2}=\Sigma \sin { }^{\omega} \theta_{\mathrm{K}} \\
& \xi_{3}=\Sigma \cos ^{2} \omega_{K} \\
& \xi_{4}=\Sigma \sin ^{2} \omega_{\mathrm{K}} \\
& \xi_{5}=\Sigma \sin \omega_{\theta_{K}} \cos \omega_{\mathrm{K}}
\end{aligned}
$$


Relations A-2 become then

$$
\begin{aligned}
& \alpha_{0}-\mathrm{NA}+\mathrm{B}\left(\xi_{1} \cos \mathrm{P}+\xi_{2} \sin \mathrm{P}\right)=0 \\
& \left(\alpha_{1}-\mathrm{A} \xi_{1}\right) \cos \mathrm{P}+\left(\alpha_{2}-\mathrm{A} \xi_{2}\right) \sin \mathrm{P} \\
& =-\mathrm{B}\left(\xi_{3} \cos ^{2} \mathrm{P}+\xi_{4} \sin ^{2} \mathrm{P}+\xi_{5} \sin 2 \mathrm{P}\right) \\
& \left(\alpha_{1}-\mathrm{A} \xi_{1}\right) \sin \mathrm{P}-\left(\alpha_{2}-\mathrm{A} \xi_{2}\right) \cos \mathrm{P} \\
& =\mathrm{B}\left\{\xi_{5} \cos 2 \mathrm{P}-\left(\xi_{3}-\xi_{4}\right) \sin \mathrm{P} \cos \mathrm{P}\right\}
\end{aligned}
$$

By noting that

$$
\begin{aligned}
& \xi_{1}=\xi_{2}=0 \\
& \xi_{3}=\xi_{4}=\frac{N}{2} \text { when } \theta_{K}=\frac{K-1}{N} \quad T, K=1,2, \ldots . N \quad A-8 \\
& \xi_{5}=0
\end{aligned}
$$

where $T=$ period of the cyclic data, one obtains

$$
\begin{aligned}
& A=\frac{\sum t_{K}}{N} \\
& B=-\frac{2}{N} \sqrt{\left(\sum t_{K} \cos \omega_{K}\right)^{2}+\left(\sum t_{K} \sin \omega_{K}\right)^{2}} \\
& P=\tan ^{-1} \frac{\sum t_{K} \sin \omega_{\theta_{K}}}{\sum t_{K} \cos \omega_{K}}
\end{aligned}
$$

An advantage of the least squares technique employed in this analysis is that 1 does not require conditions A-8. Thus, the earth temperature observation for certain months could be completely missing whereas some other months may have several observations. Although the determination of $A, B$ and $P$ for this procedure is much more complicated than those expressed by A-9, an iterative solution of A-7 is readily obtalned by an electronic computer. 
The iterative solution of $\mathrm{A}-7$ is actually unnecessary if the expression of $A-4$ is modified so that the normalized least squares equation A-5 are all made linear with respect to linearized variables.

It is also possible to add one more partial derivative term such $\frac{\partial S}{\partial D}=0$ to $A-5$ and solve it together with the rest of the linear normal equations. In this way it is possible to find a single (not two) thermal diffusivity that will satisfy the least squares requirement together with other least squares constants such as $\mathrm{A}, \mathrm{B}$ and $\mathrm{P}$.

Further work is in progress along this line and will be discussed in a forthcoming report. 


\section{REFERENCES}

1. Symposium on Survival Shelters, ASHRAE, June 25-27, 1962, Miami Beach, Florida.

2. Achenbach, P. R. and Kusuda, T., Numerical Analysis of the Thermal Environment of Occupied Underground Spaces with Finite Cover Using a Digital Computer, Trans., ASHRAE, Vo1. 69, 1963, pp. 439-452.

3. Drucker, E. F. and Haines, J. T., A Study of Thermal Environment in Underground Survival Shelters Using an Electronic Analog Computer, ASHRAE Journal, Vo1. 6, No. 7, July 1964, pp. 81-84.

4. Fitton, E. M. and Brooks, C. F., Soil Temperature in the United States, Month1y Weather Review, Vol. 59, January 1931.

5. Jen-Hu Chang, Ground Temperature, Vol. I and II, Blue Hill Meteorological Observatory, Harvard University, Milton, Mass., June 21, 1958.

6. History of Sol1 Temperature Stations in the United States, Key to Mete or ological Records Documentation No. 1.4, U.S. Weather Bureau, Department of Commerce, 1961.

7. Climatological Data, U.S. Weather Bureau, National Weather Record Center, Asheville, North Carolina.

8. Penrod, E. B., et a1, A Method to Describe Soll Temperature Variation, J. of the Soll Mechanics and Foundation Division Proc. of ASCE, Vo1. 84, No. SM 1, February 1958.

9. Penrod, E. B., et al, Variation of Soil Temperature at Lexington, Kentucky, from 1952-1956, Engineering Experiment Station Bulletin No. 47, September 1960.

10. Carson, J. E., Analysis of Soil and Air Temperature by Fourier Techniques, J. of Geophysical Research, Vol. 68, No. 8, Apri1 15, 1963.

11. Collins, W. D., Temperature of Water Available for Industrial Use in the United States, U. S. Geological Survey Water Supply Paper 520-F, 1925 .

12. Carslaw, H. S. and Jaeger, J. C., Conduction of Heat in Solids, Oxford at the Clarendon Press, 1959, pp. 81-83.

13. Eckert, E. R. G. and Drake, R. M., Heat and Mass Transfer, McGrawHil1 Book Co., Inc., New York, Toronto, London 1959, pp. 99-107. 
14. Langbein, W. B., Computing Soil Temperatures, Trans., American Geophysical Union, Vo1. 30, No.4, August 1949.

15. Lettan, H., Theory of Surface-Temperature and Heat-Transfer Oscillation Near a Level Ground Surface, Trans., American Geophysical Union, Vo1. 32, No. 2, Apri1 1951.

16. Pratt, A. W. and Daws, L. F., Heat Transfer in Deep Underground Tunnels, National Building Studies Research Paper 26, Department of Scientific and Industrial Research, 1958, London.

17. Guide and Data Book, 1964 Application Volume, Section III, Chapter 30, Survival Shelters, pp. 333-352.

18. Carter, C. I., Soil Temperature, Moisture Content, and Thermal Properties, Tennessee Valley Area 1949, 1950 and 1951, Bulletin No. 15, June 1951, Engineering Experiment Station, The University of Tennessee, Knoxville. 
F1gures ST-1 to Annual average earth temperature and amplitude plotted ST-19 against depth

Flgures SP-1 to Barth temperature phase angle plotted agalnst depth SP -19 



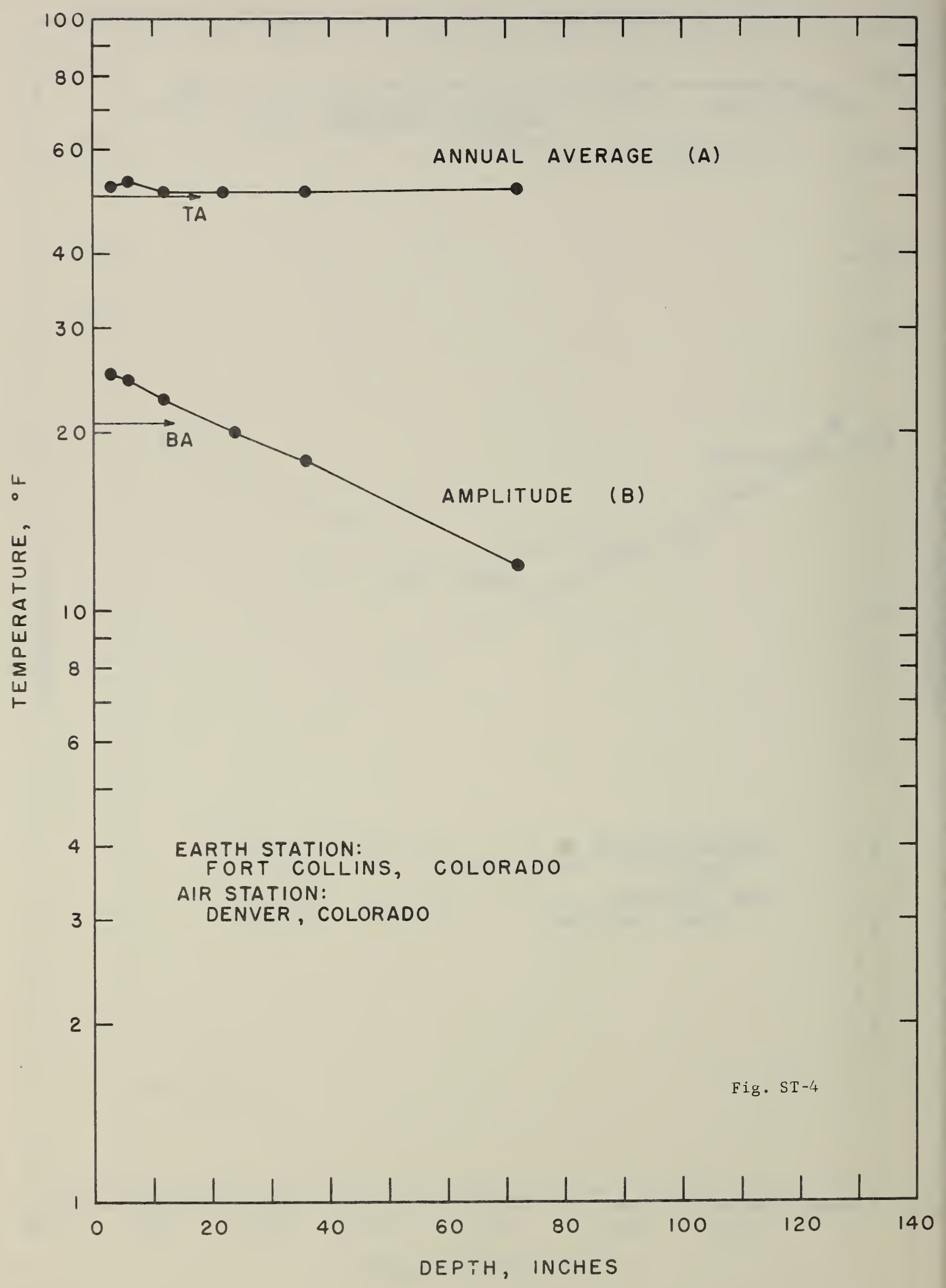




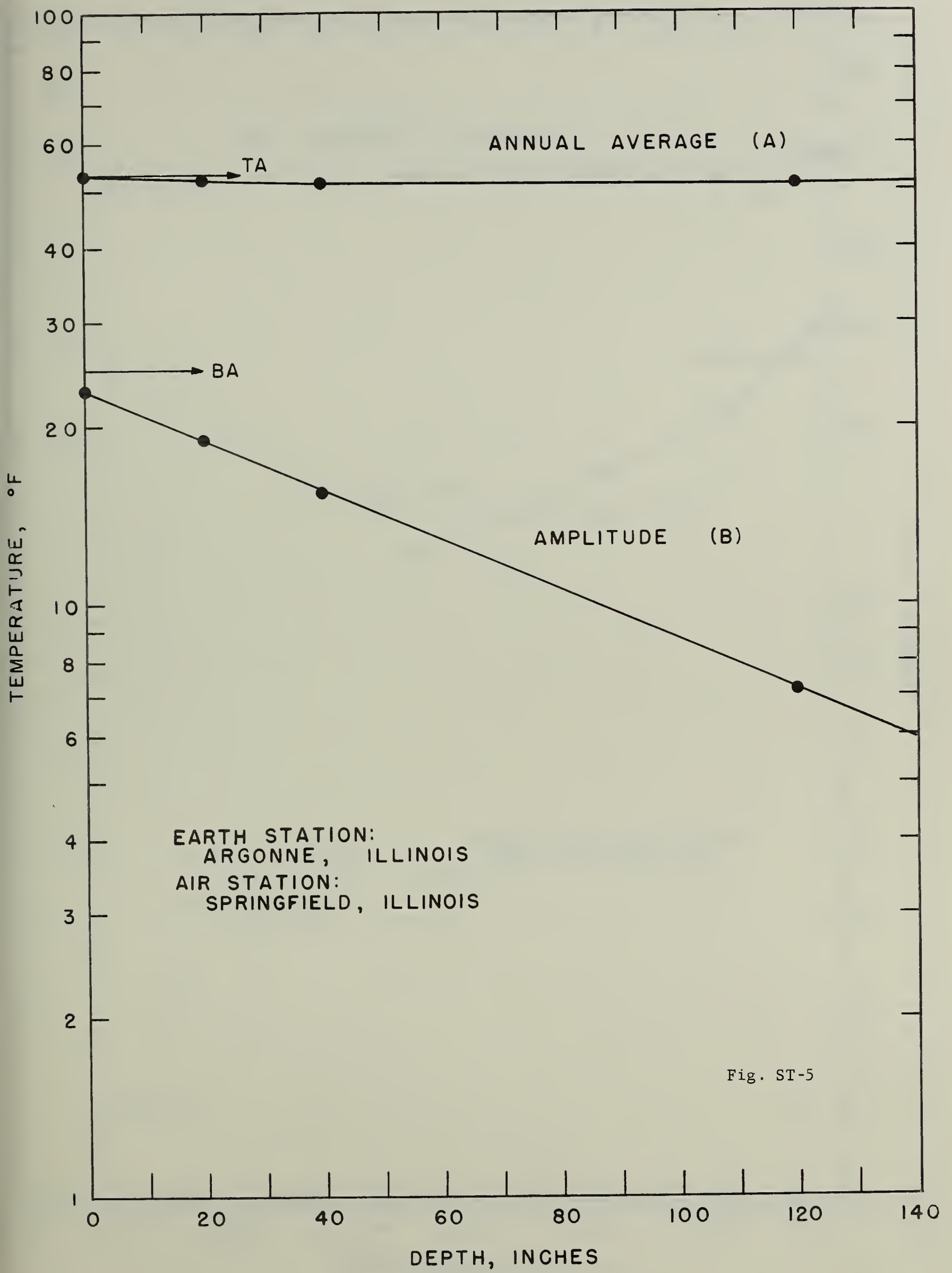




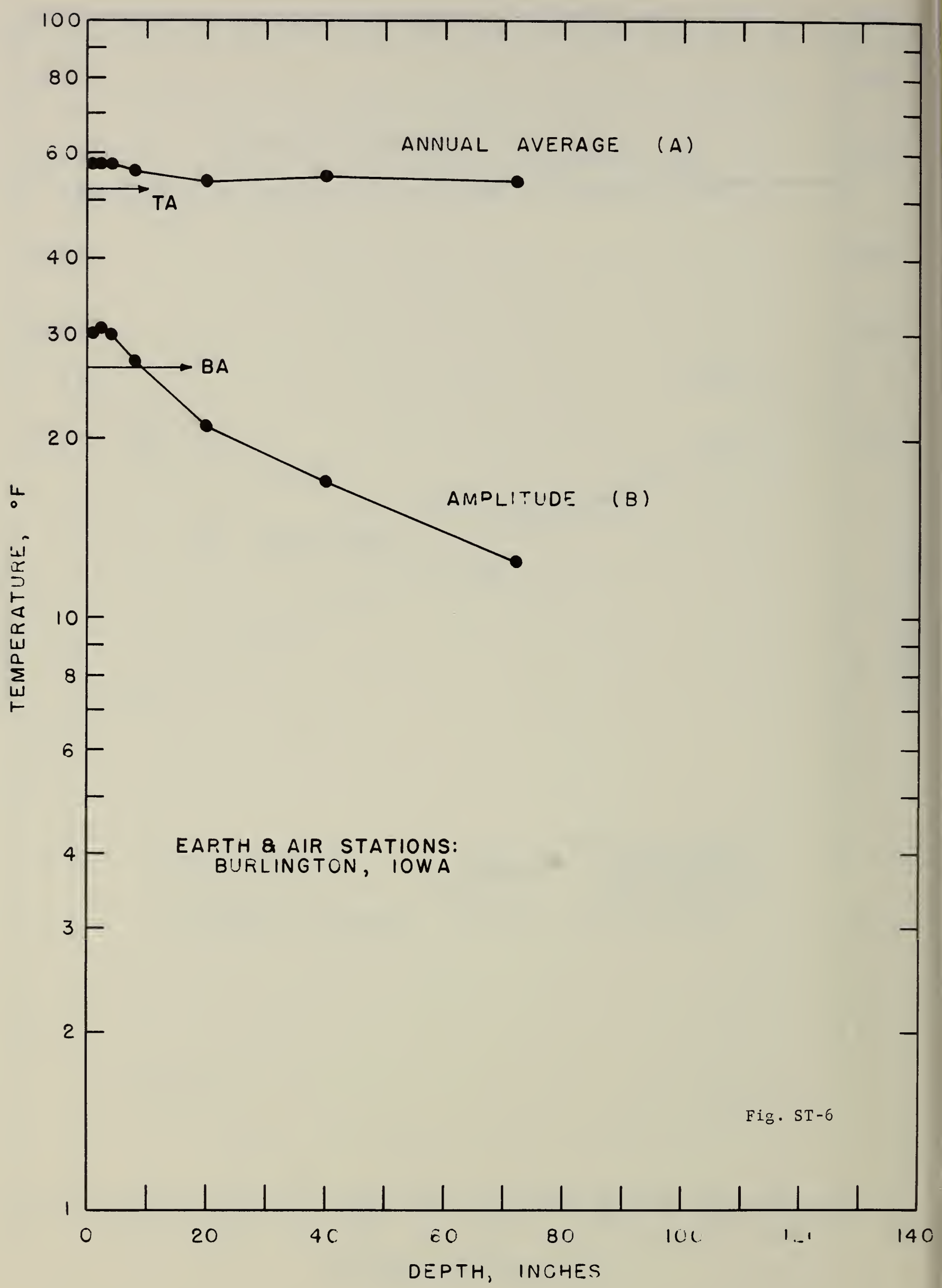




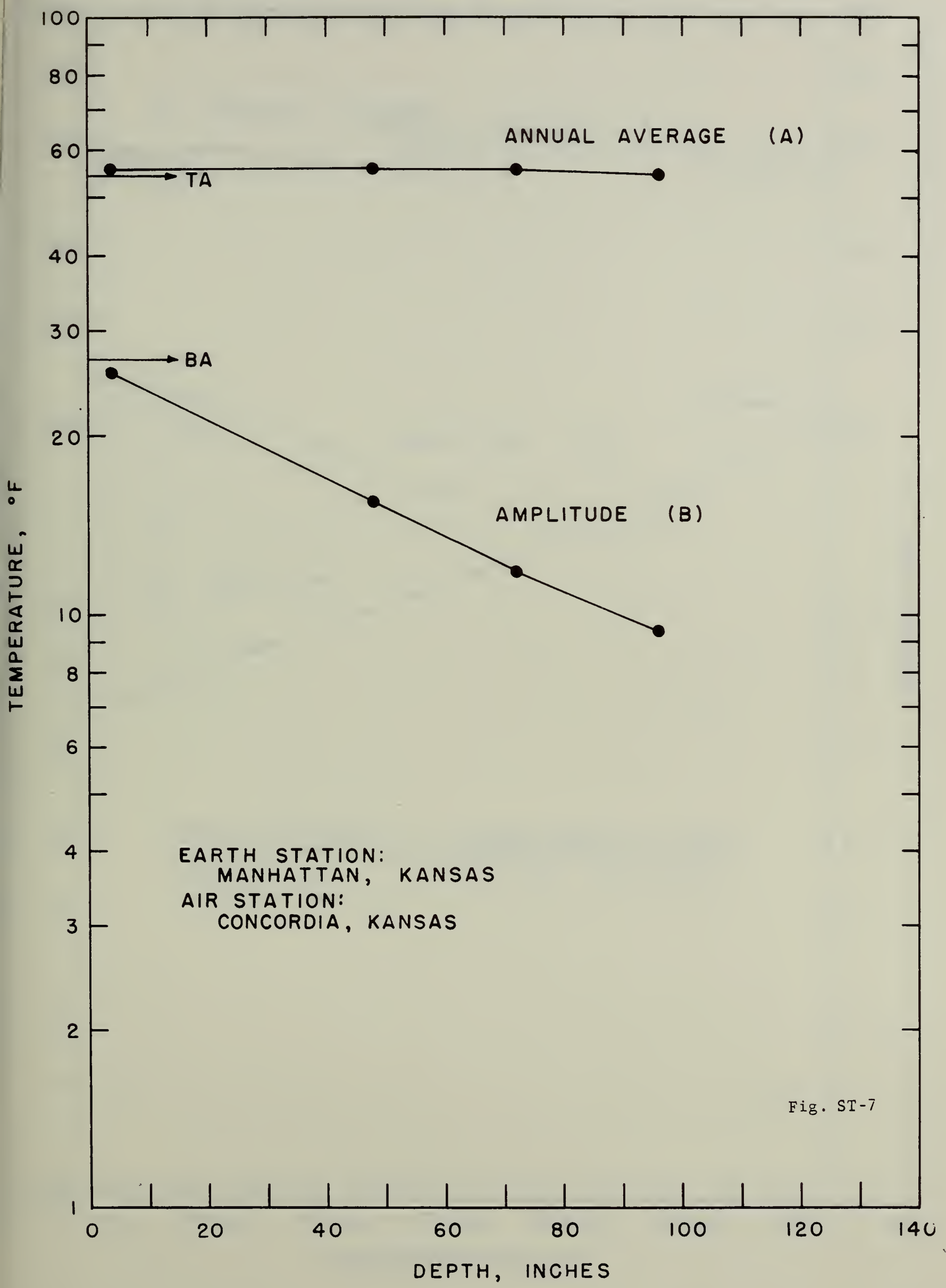




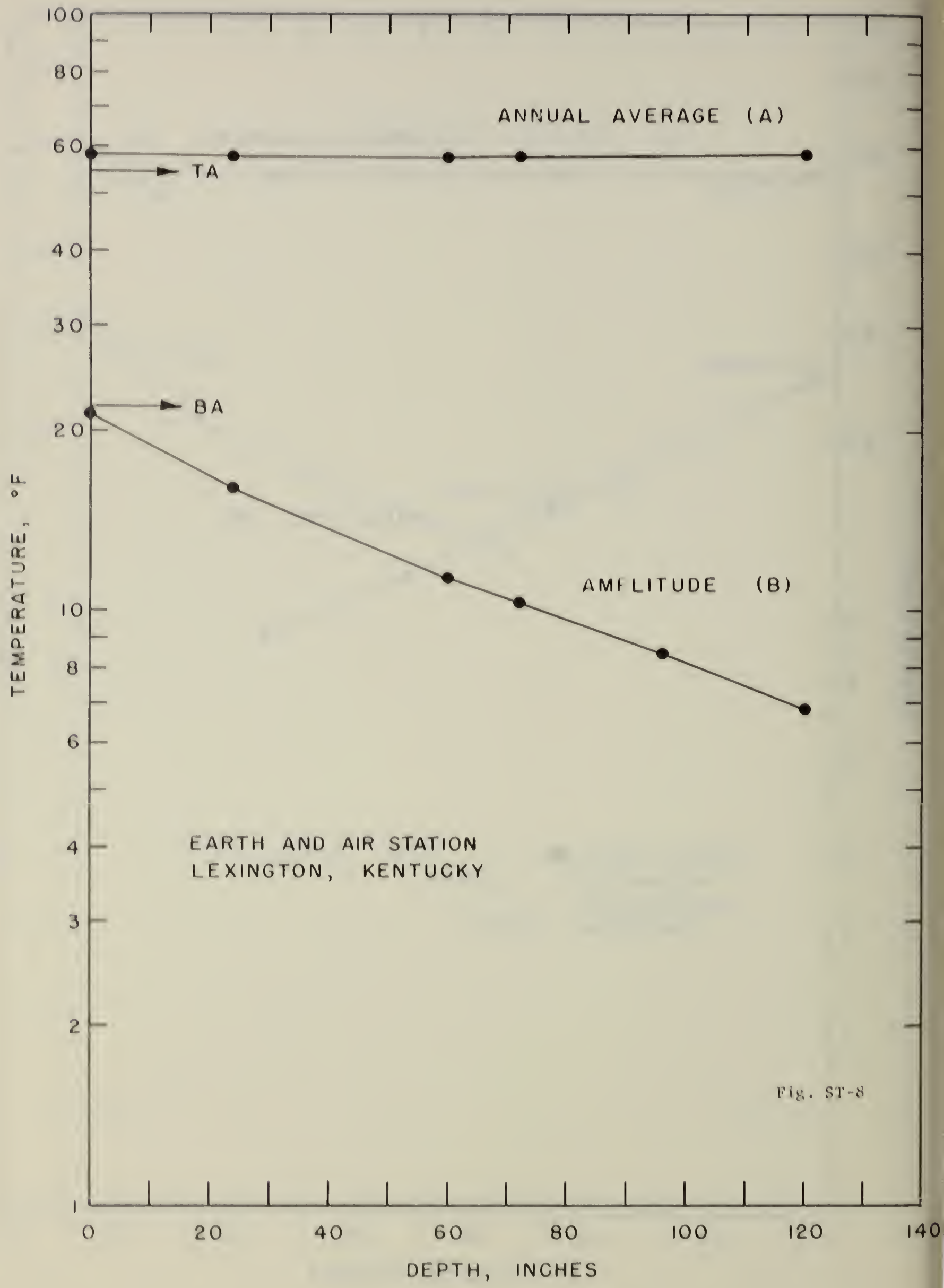




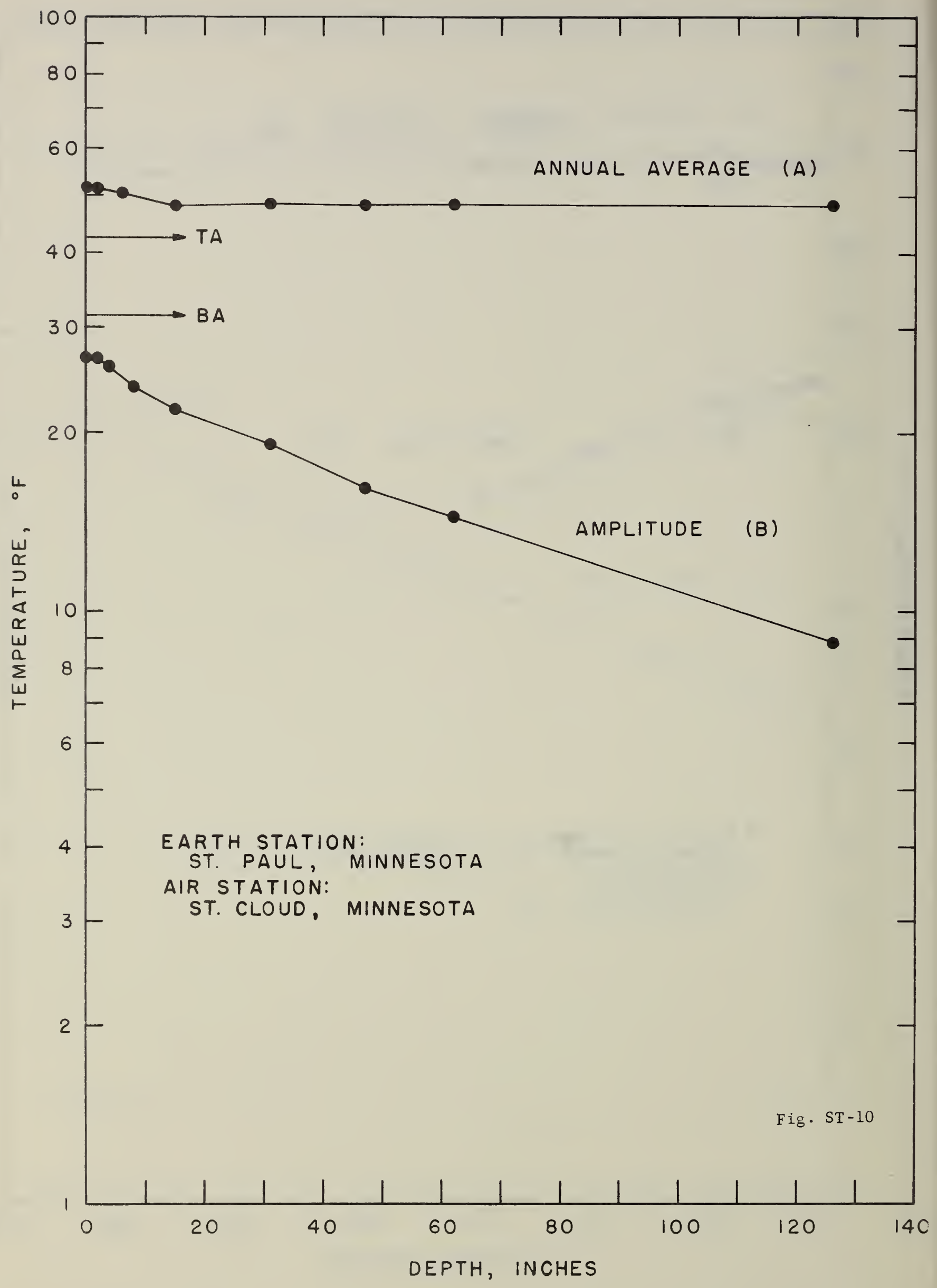




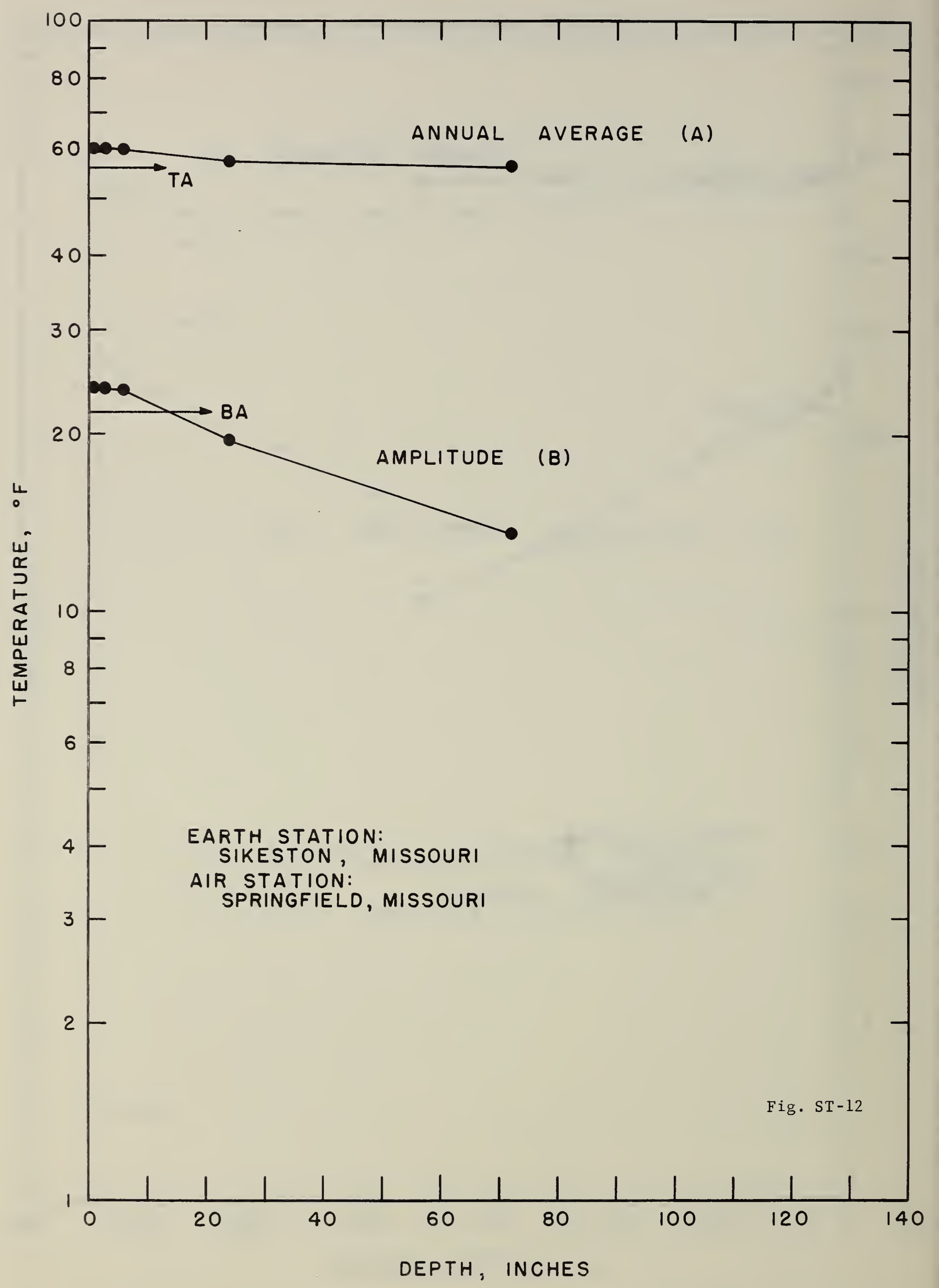




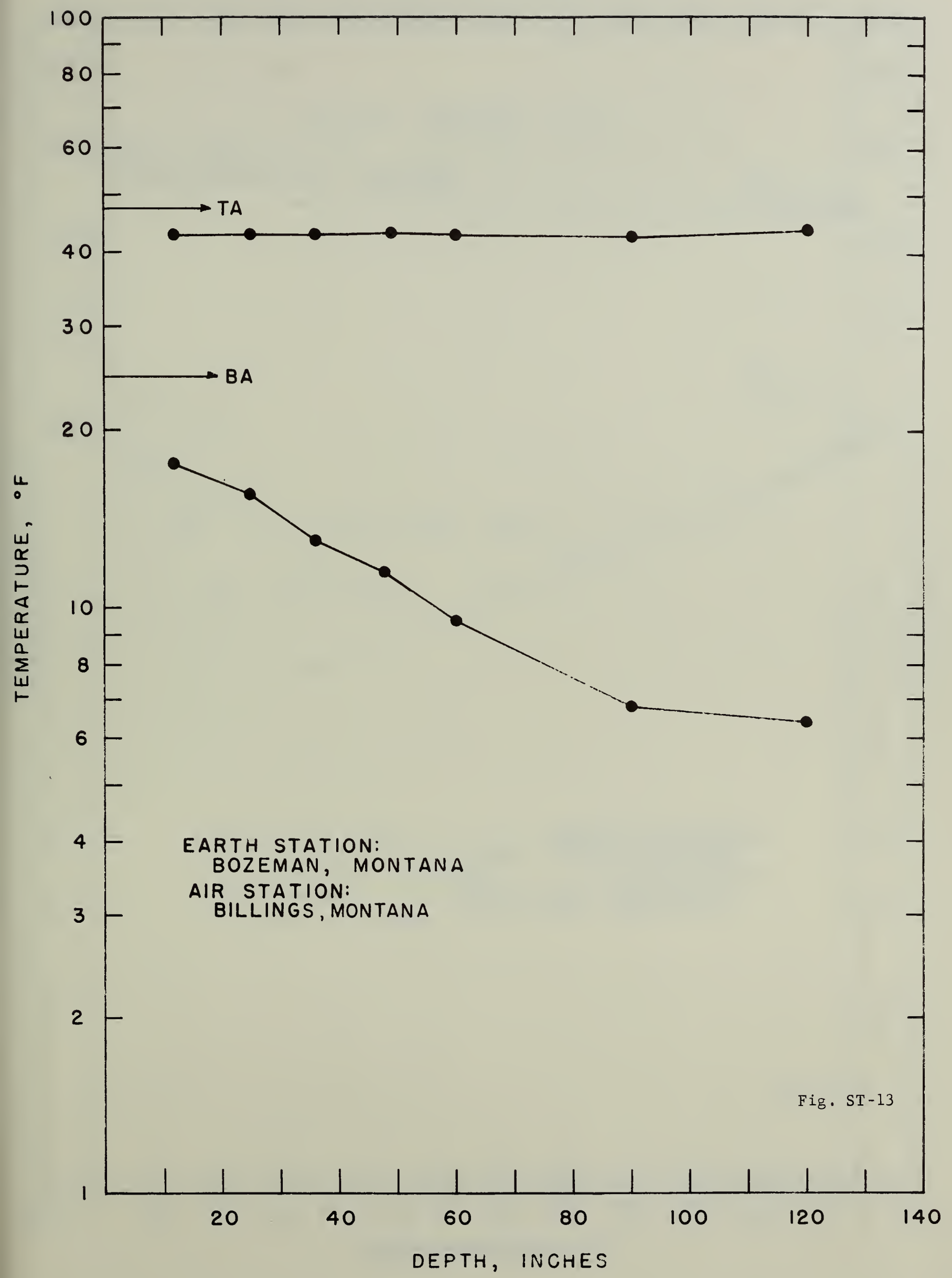




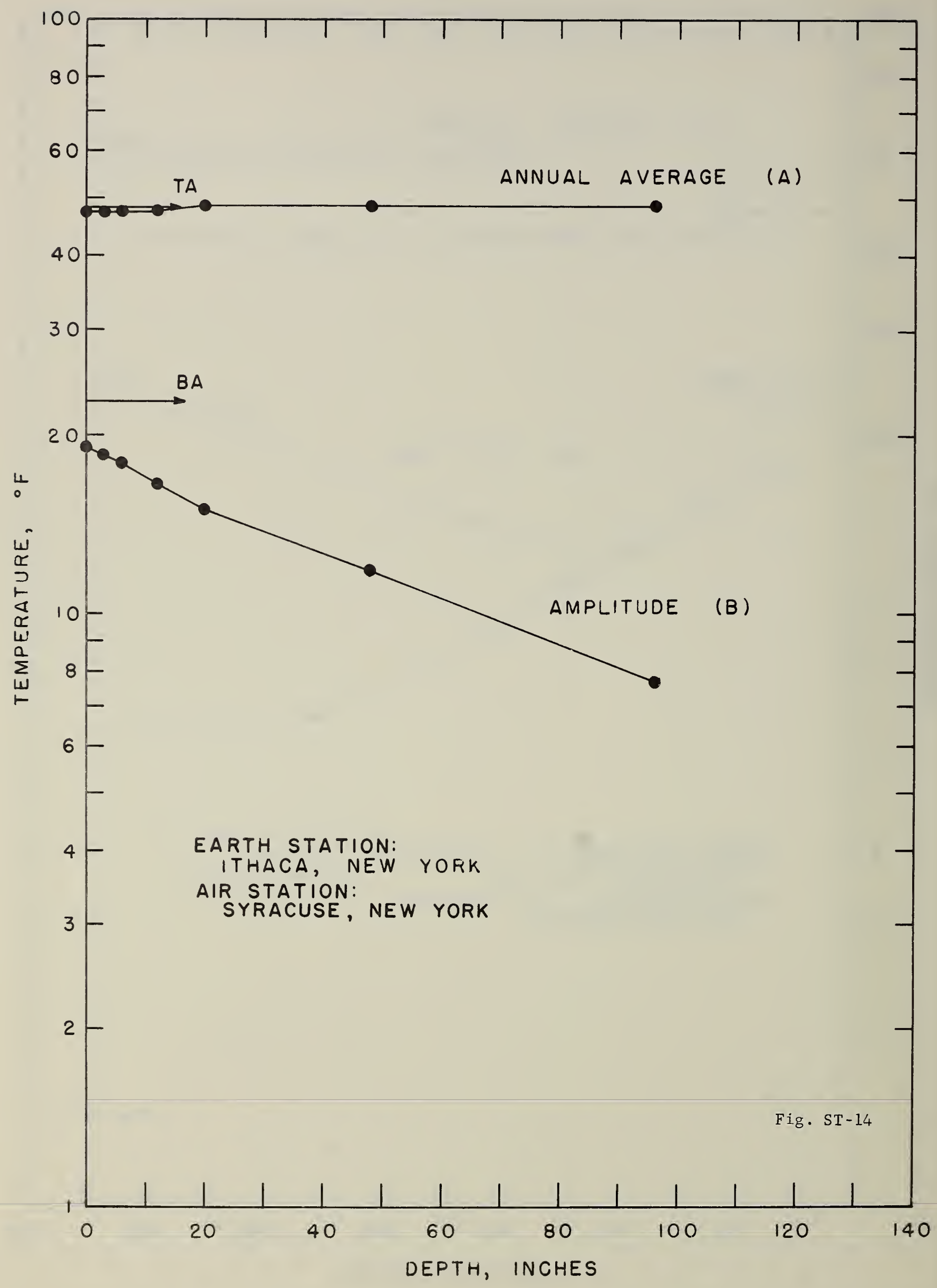




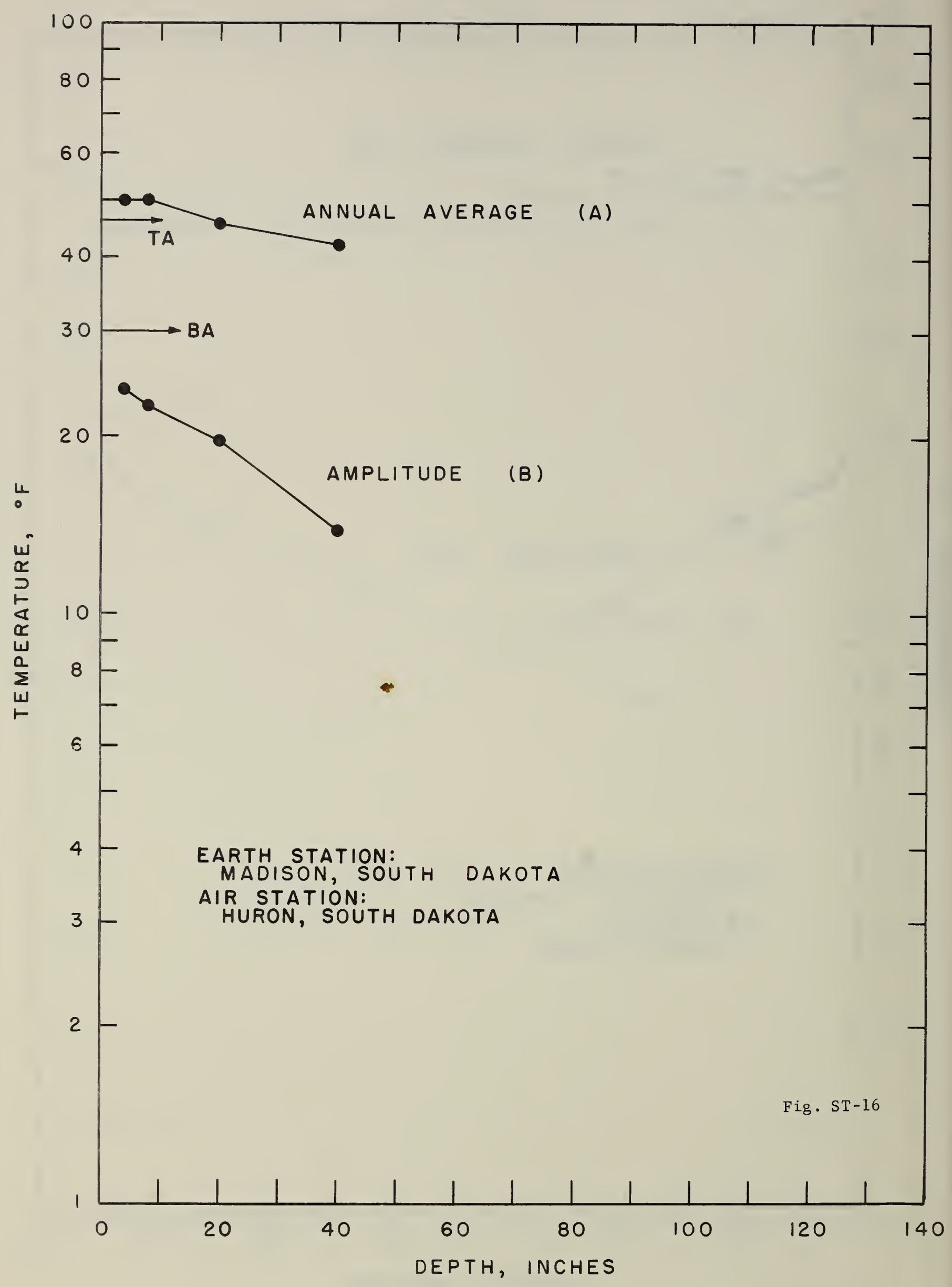




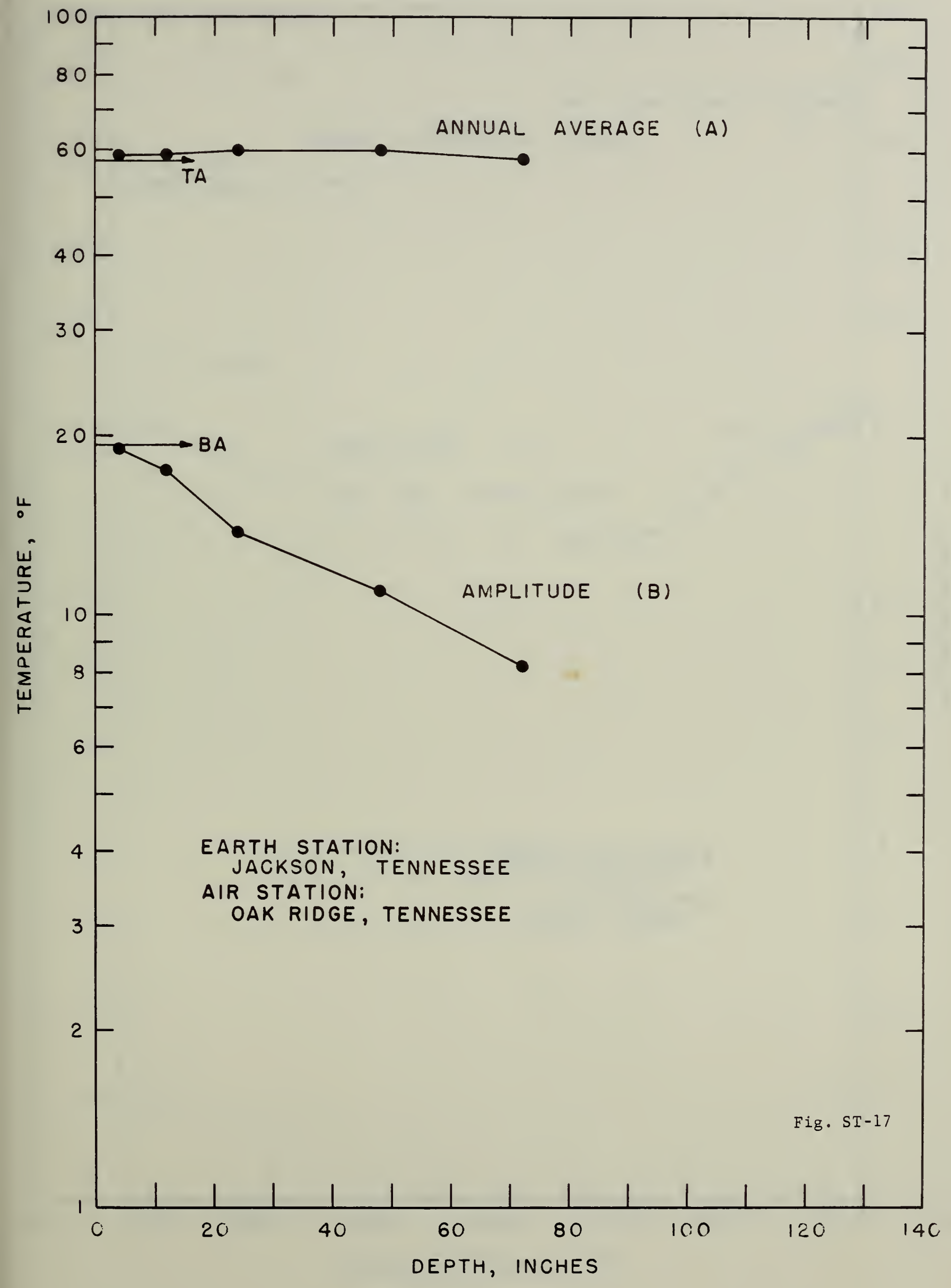




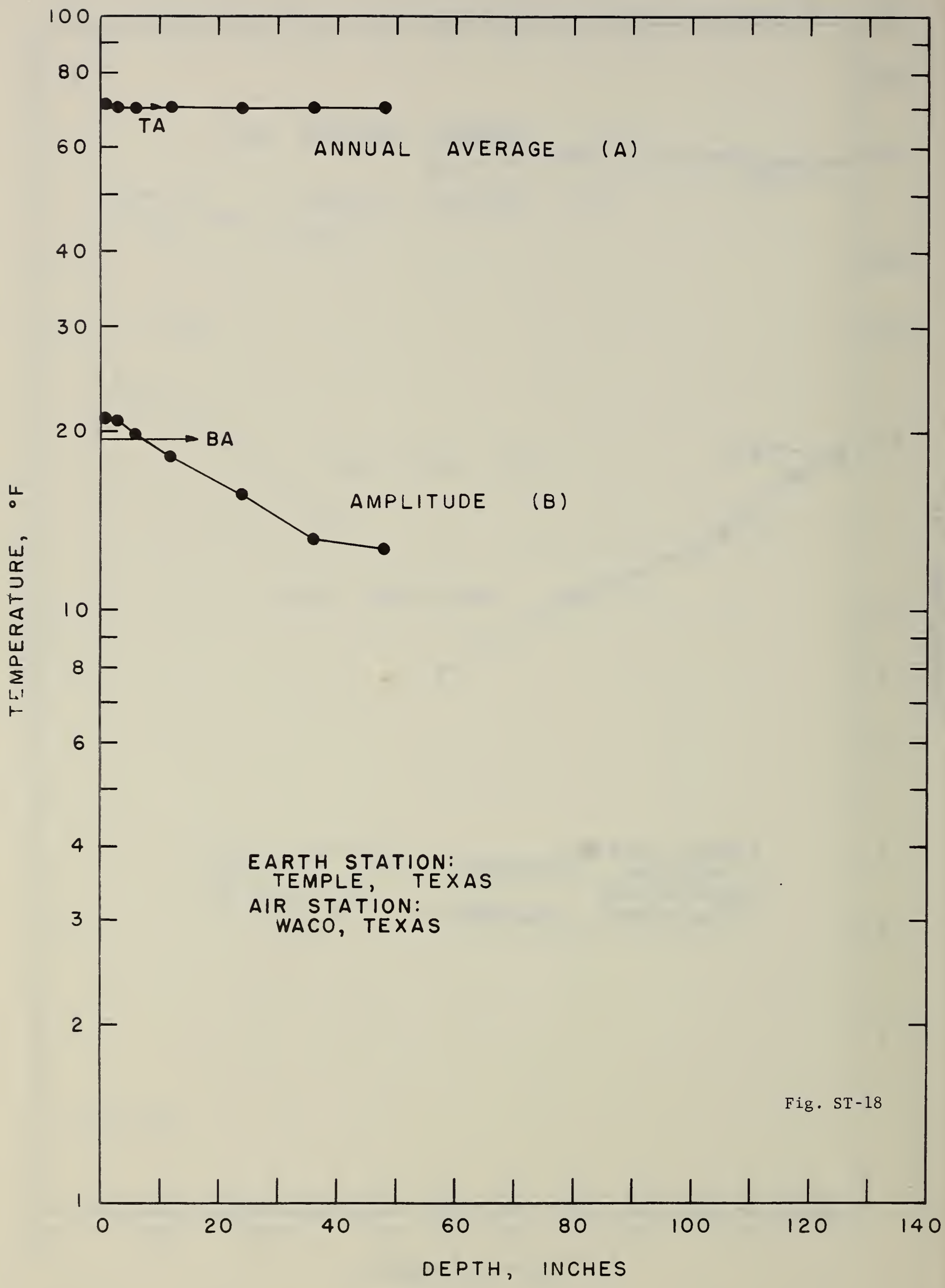




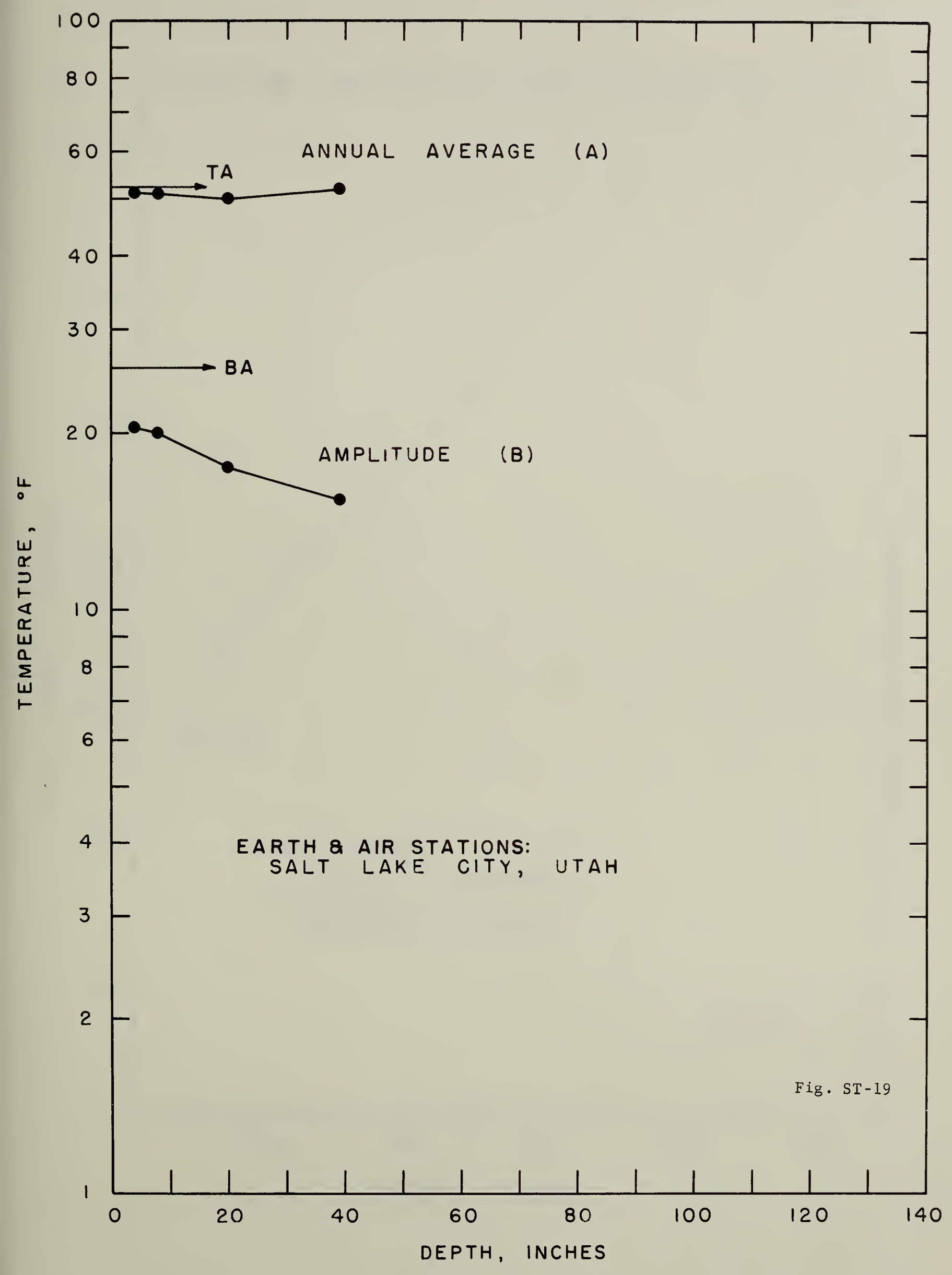





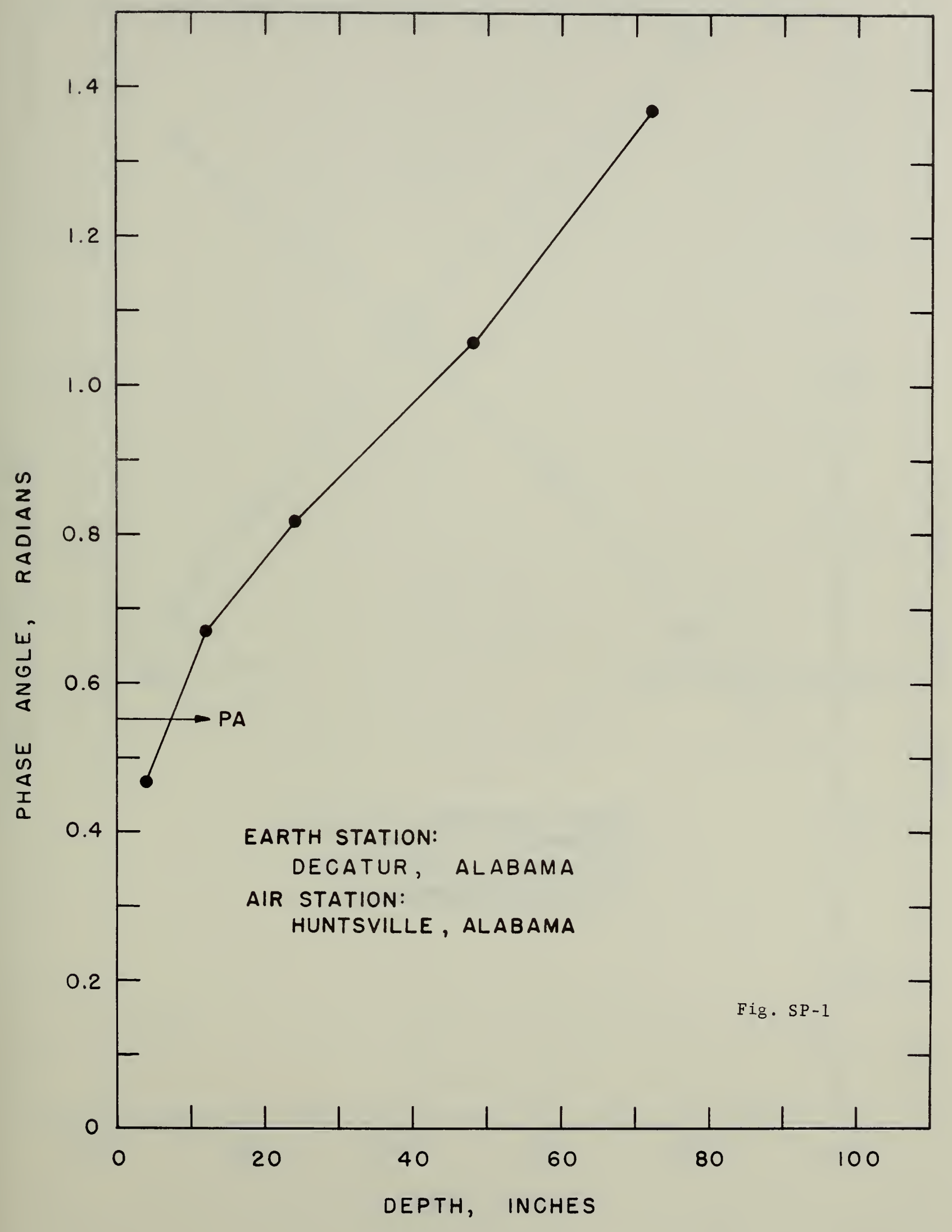




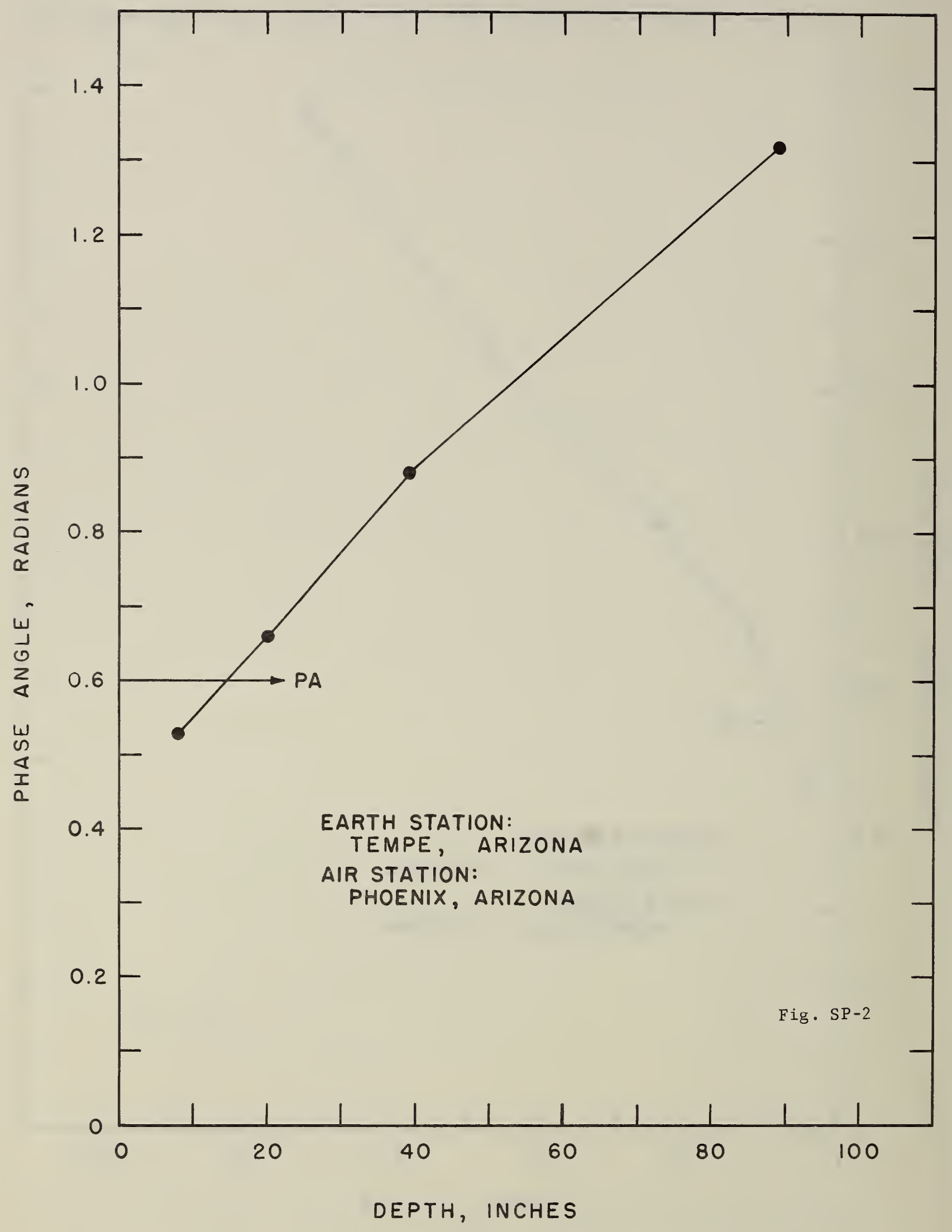




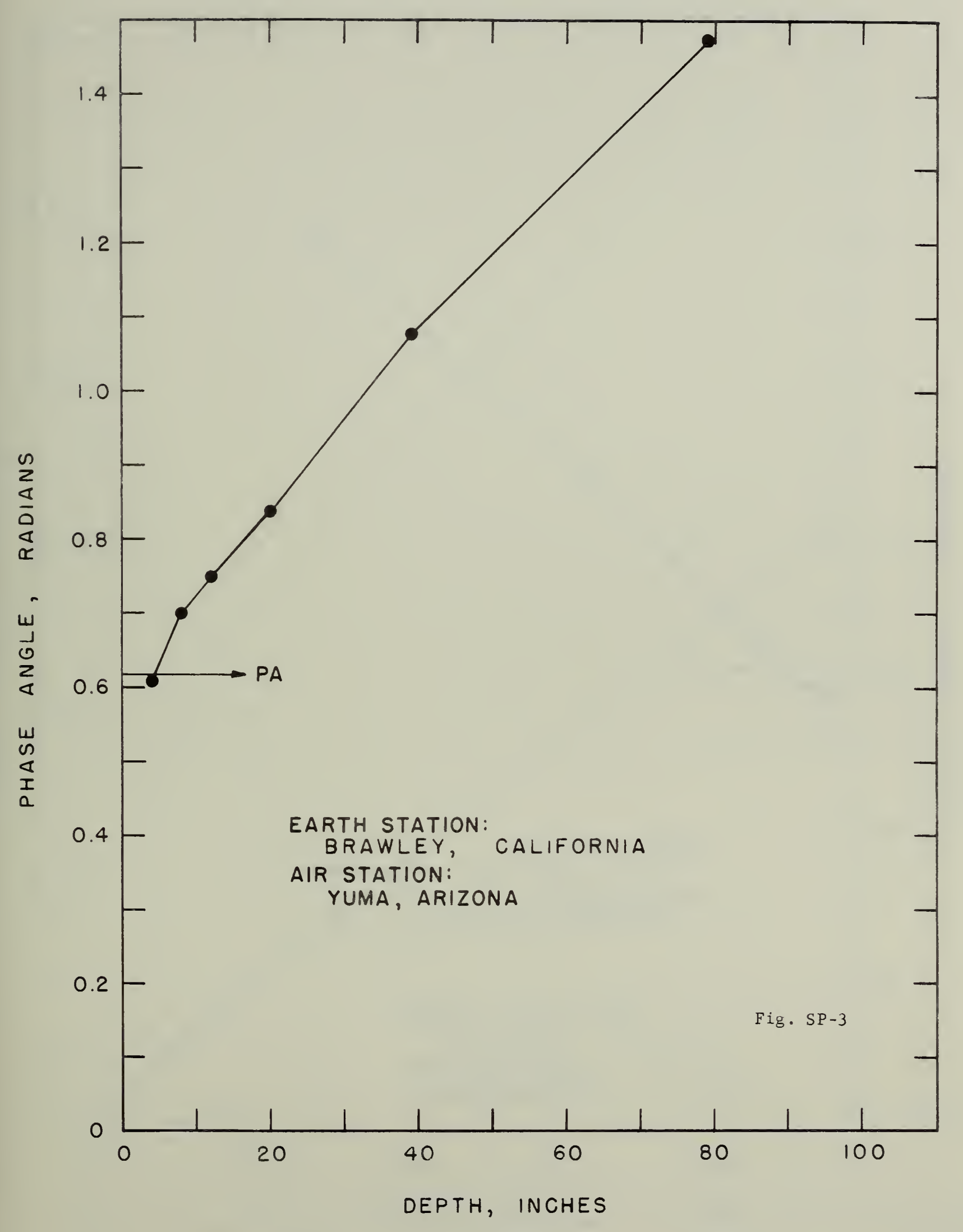




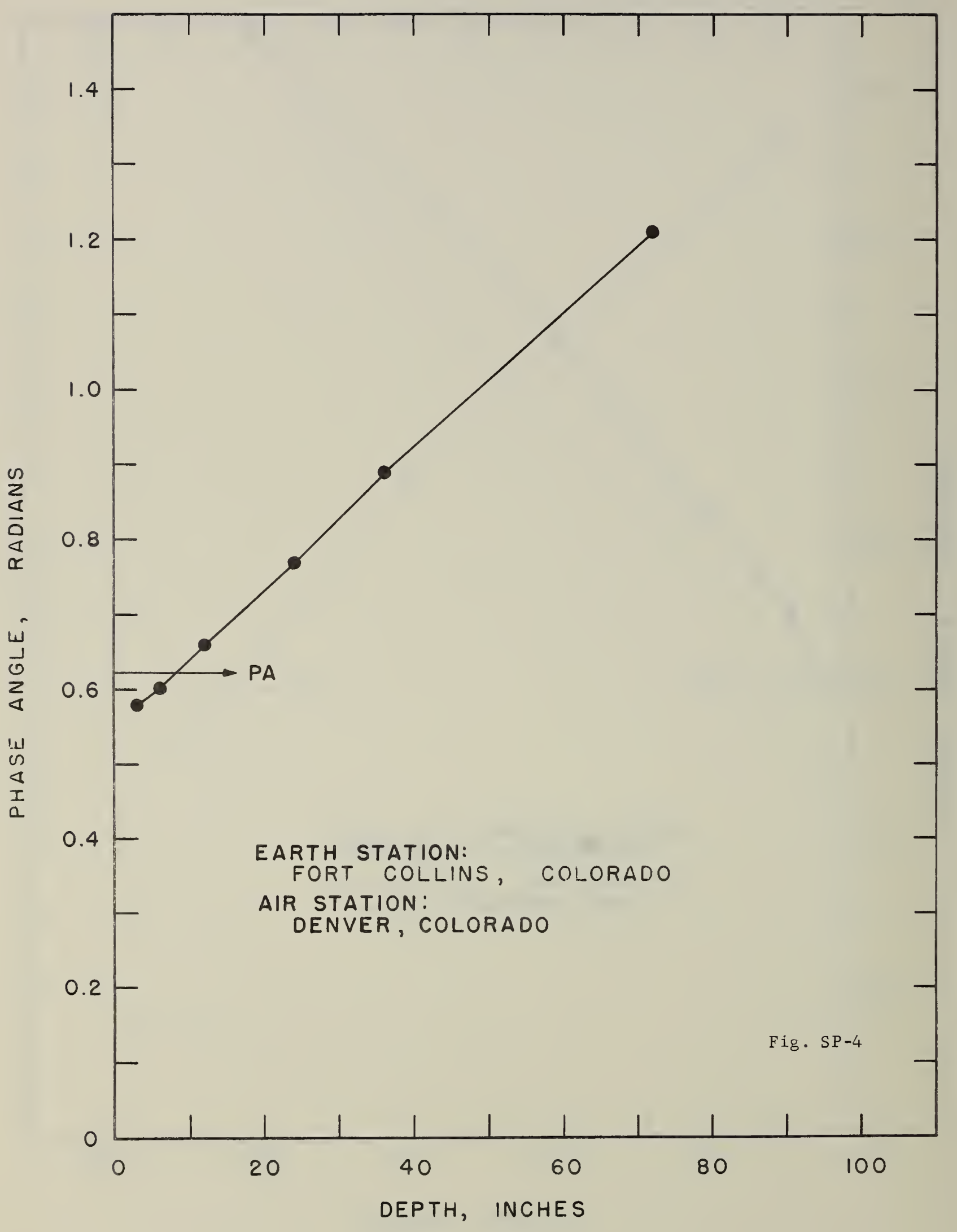




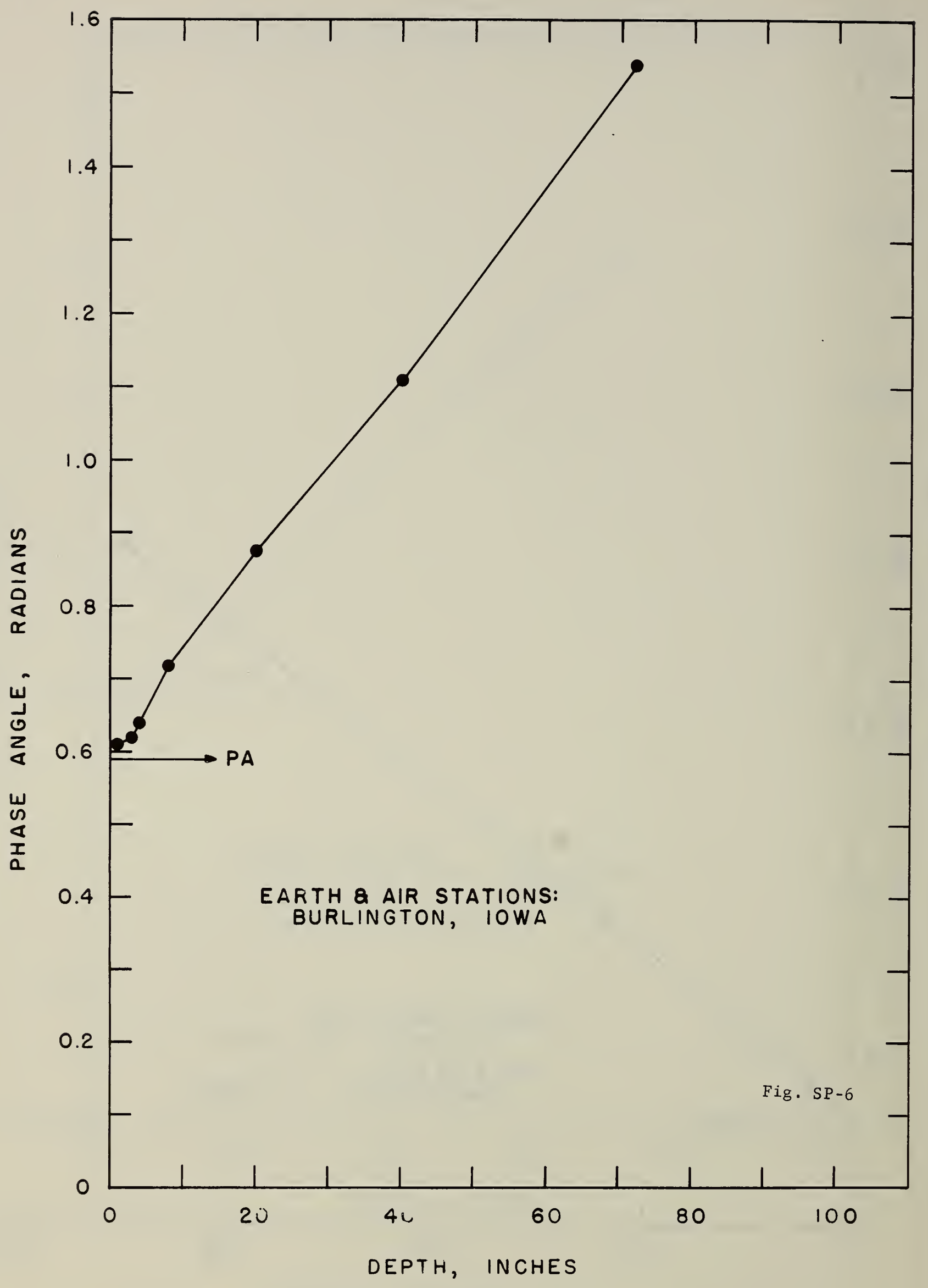




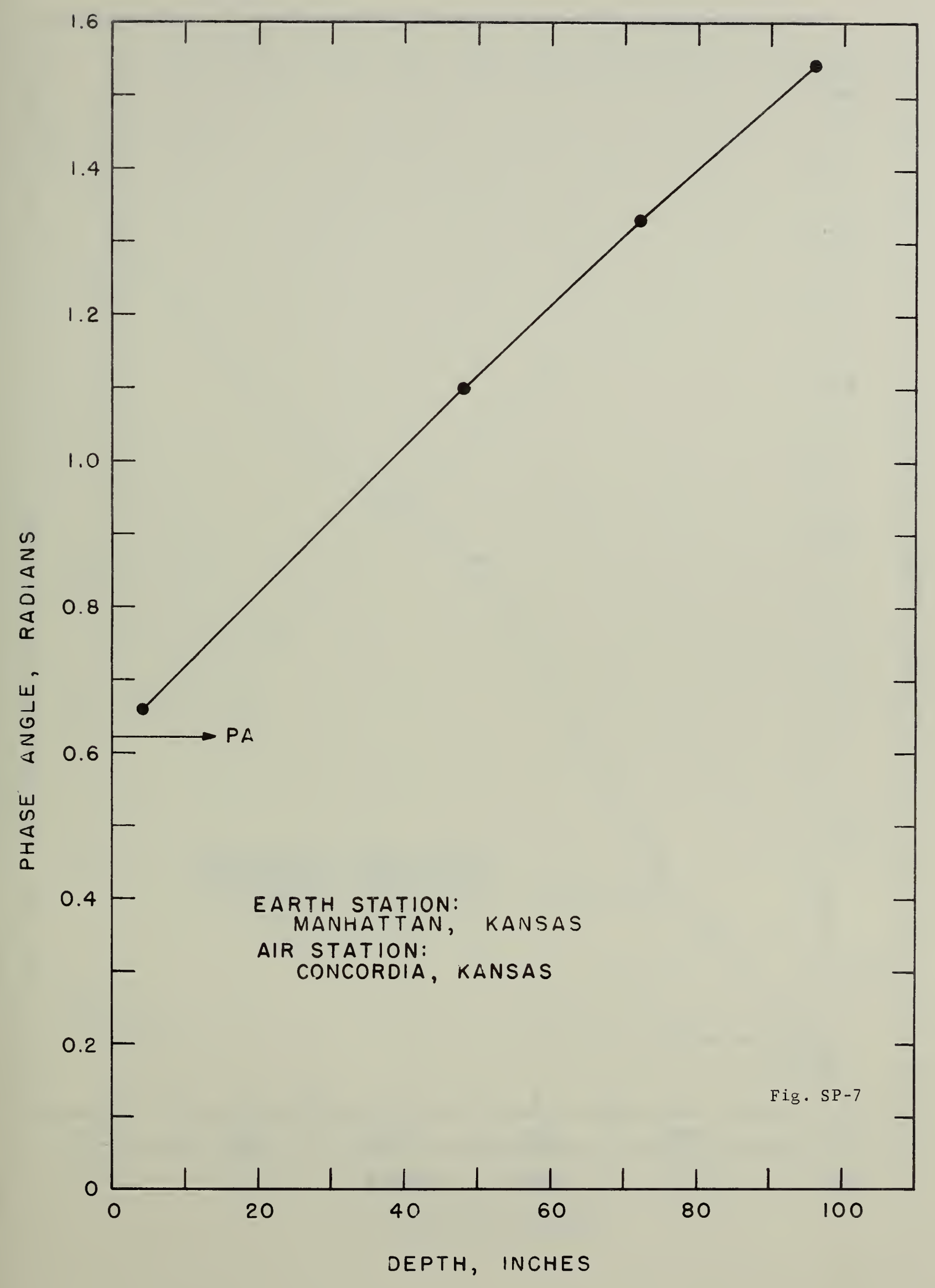




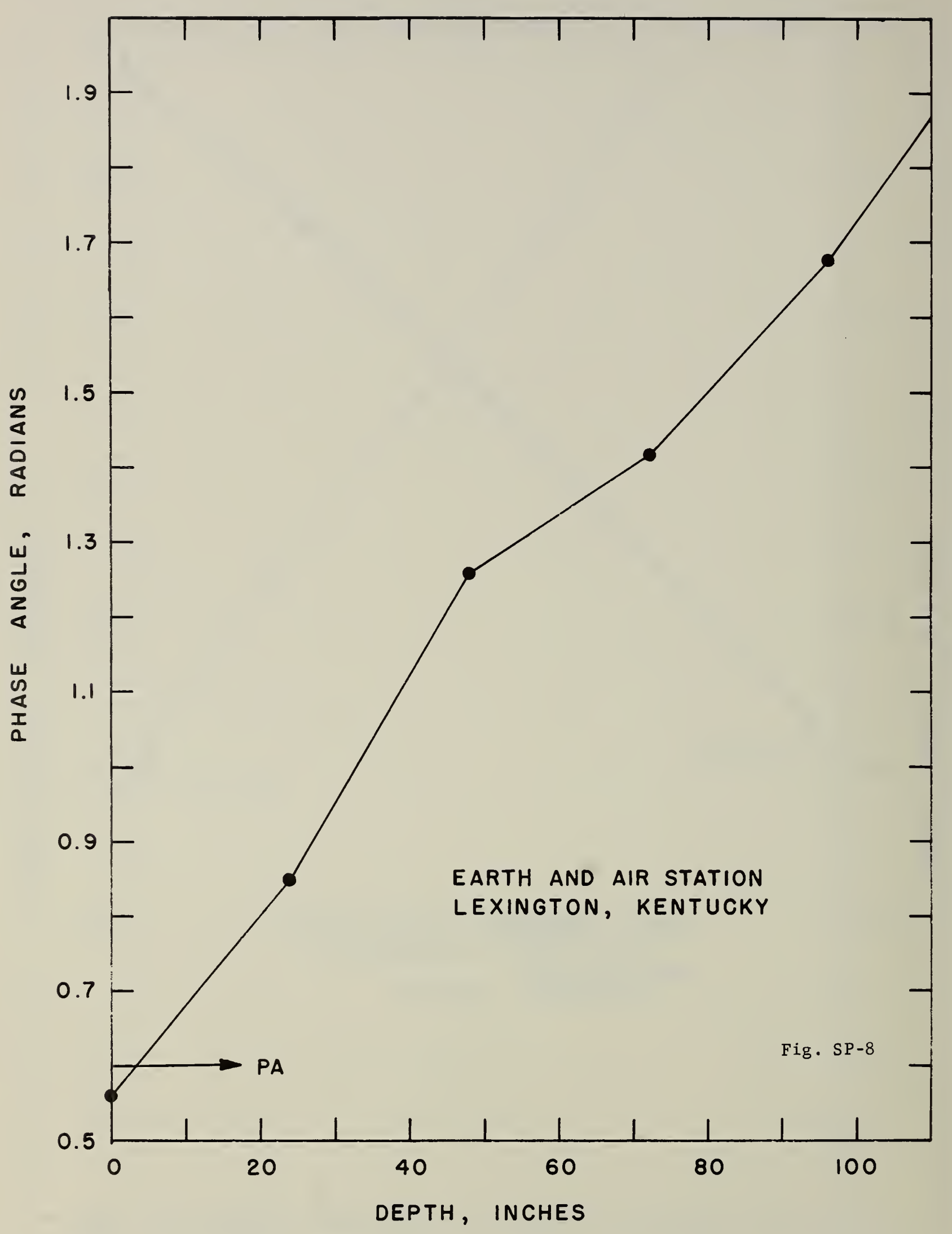




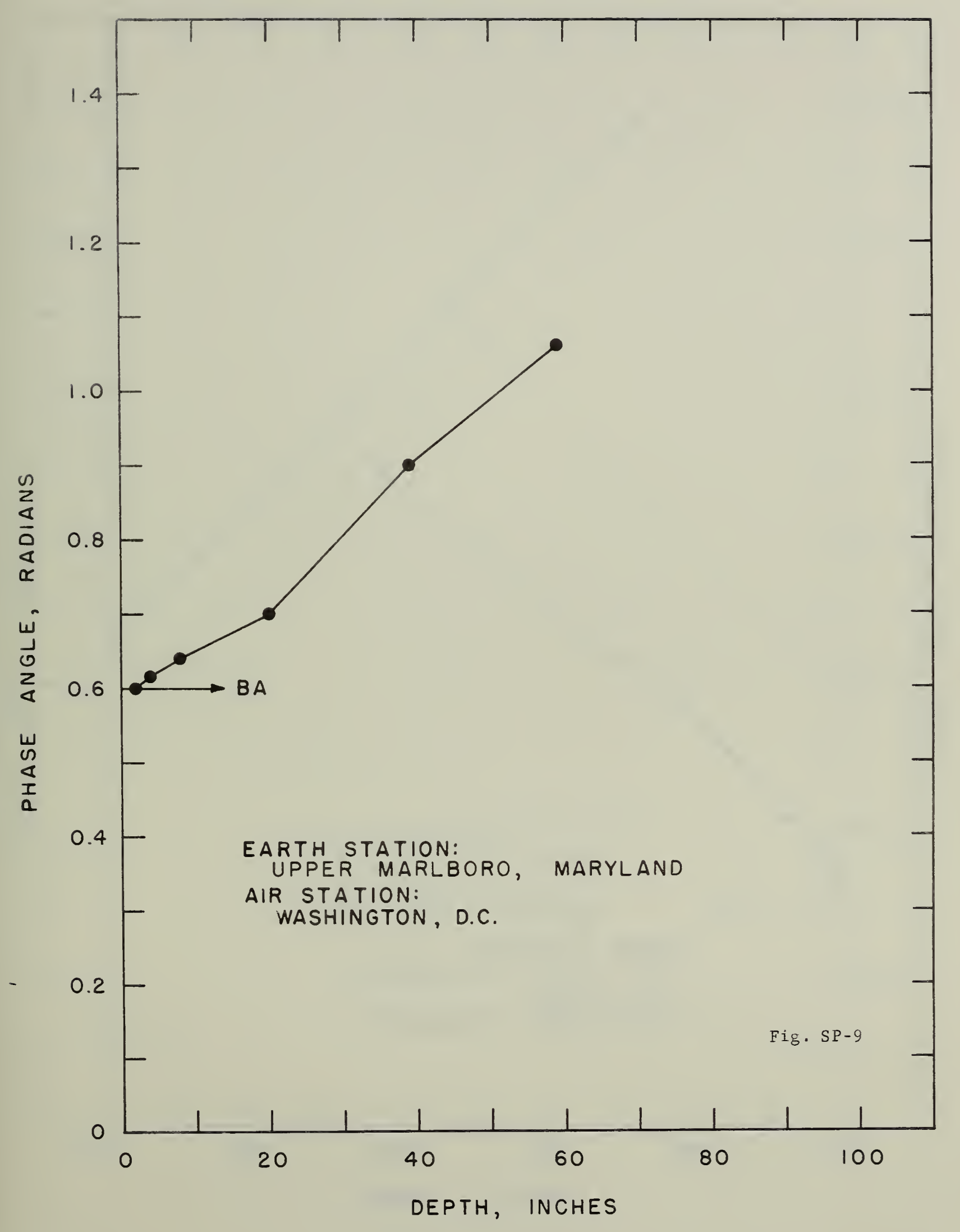




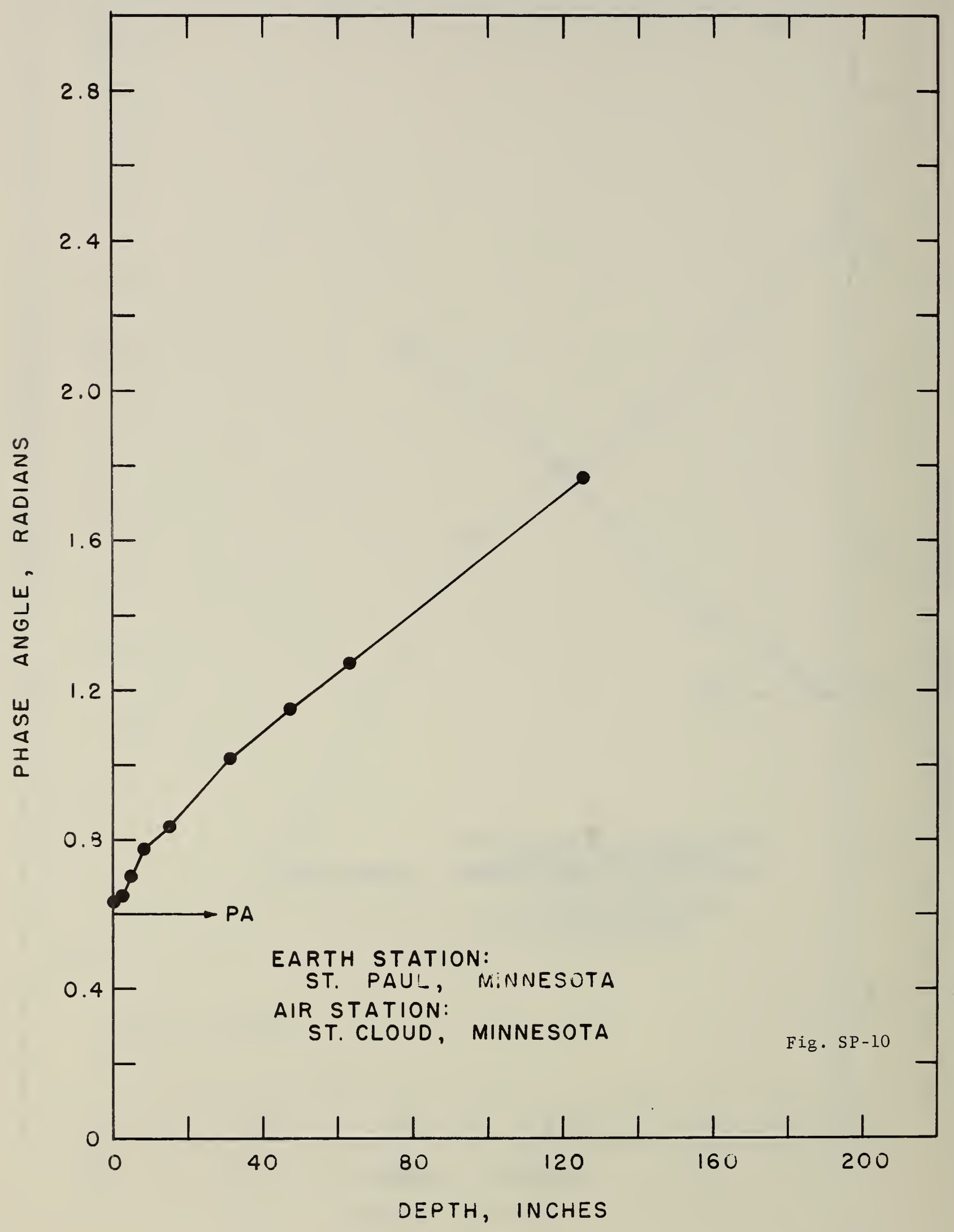




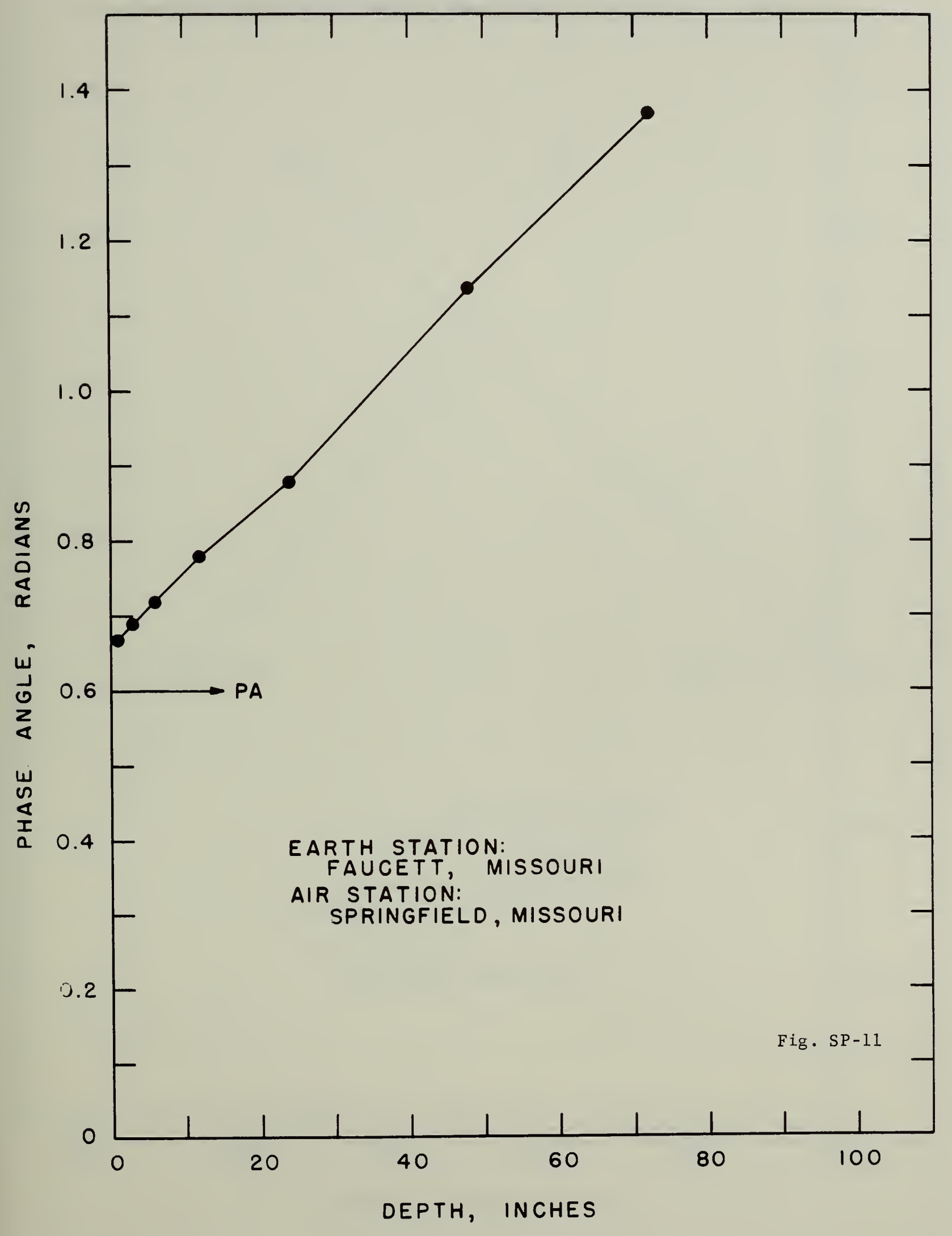




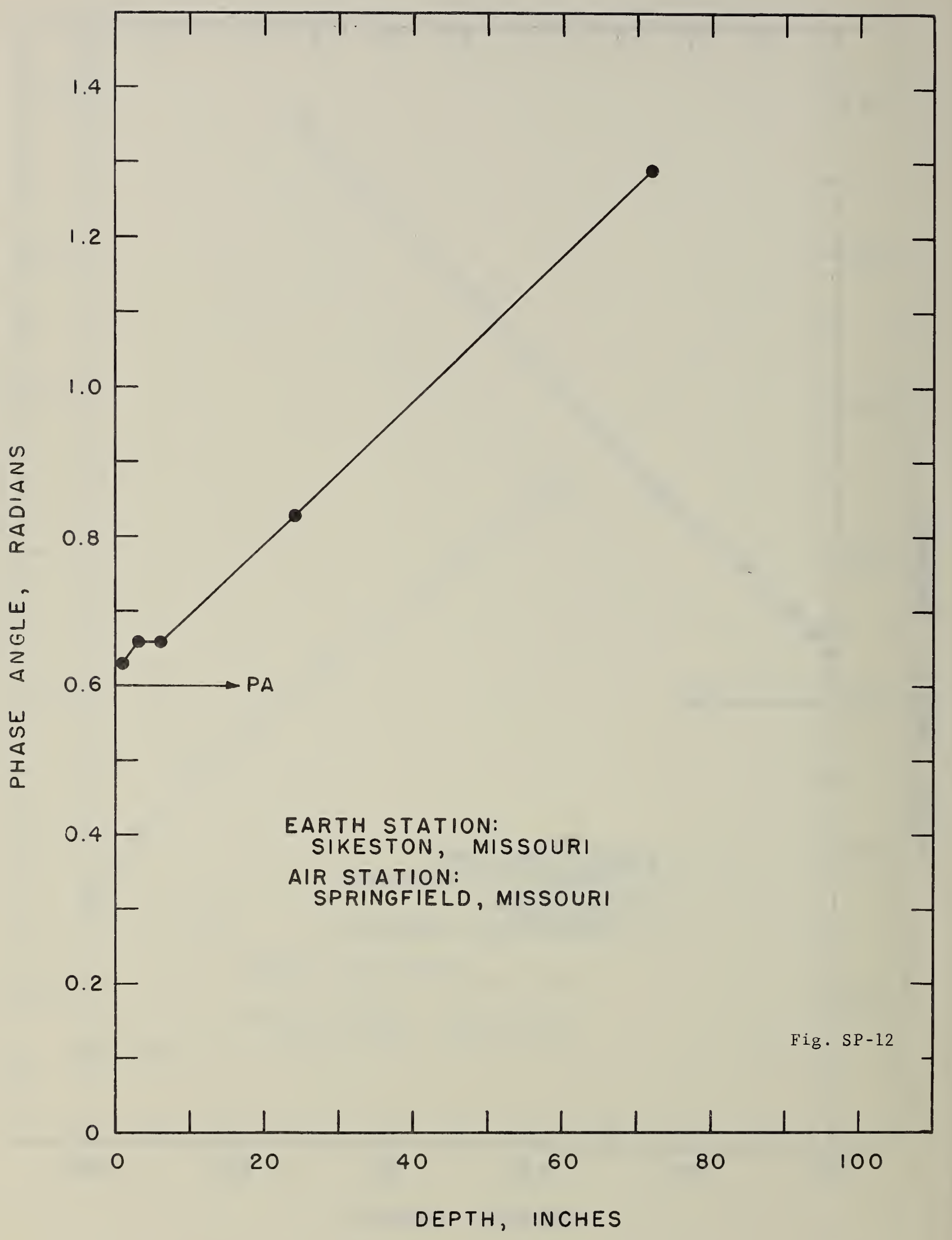




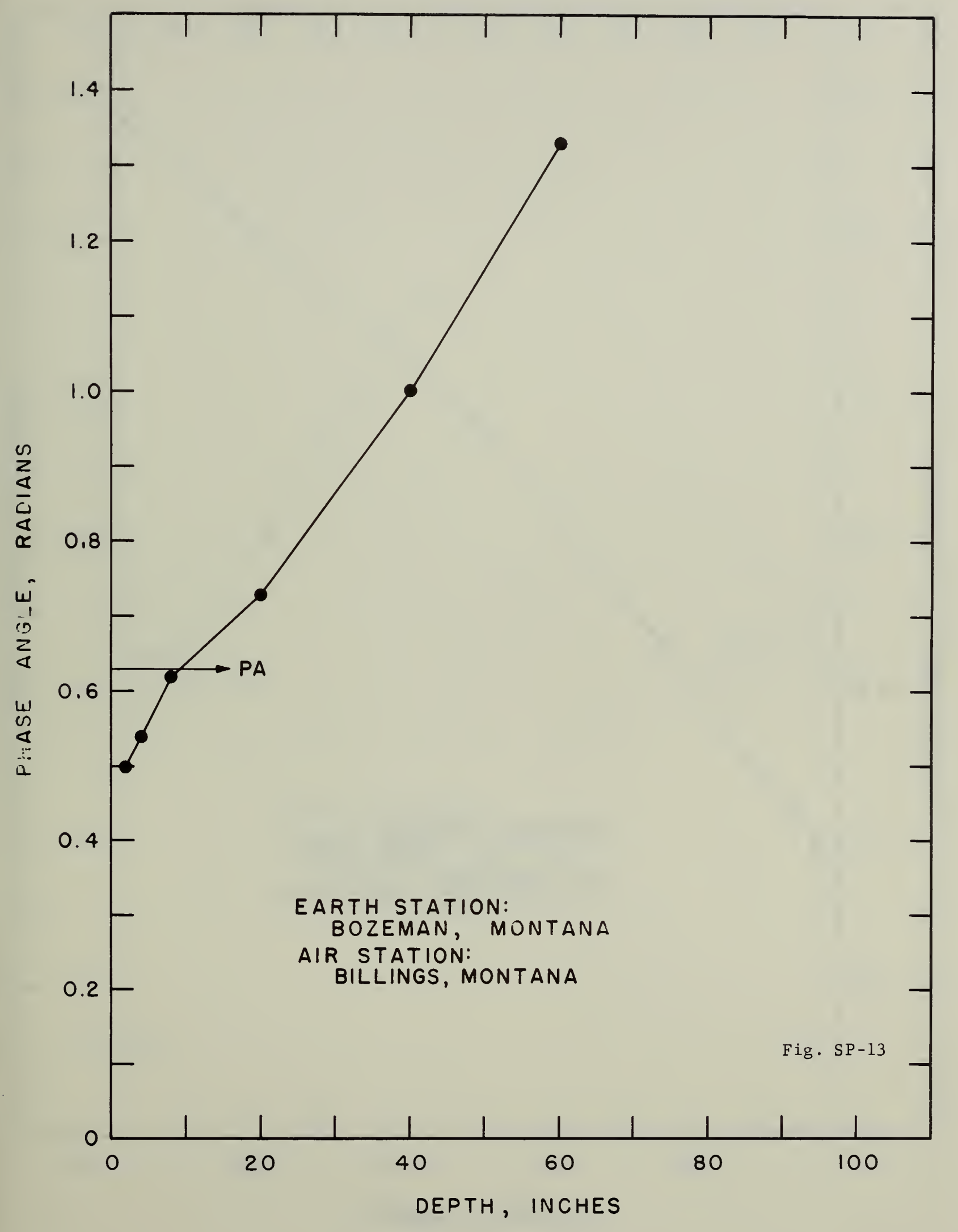




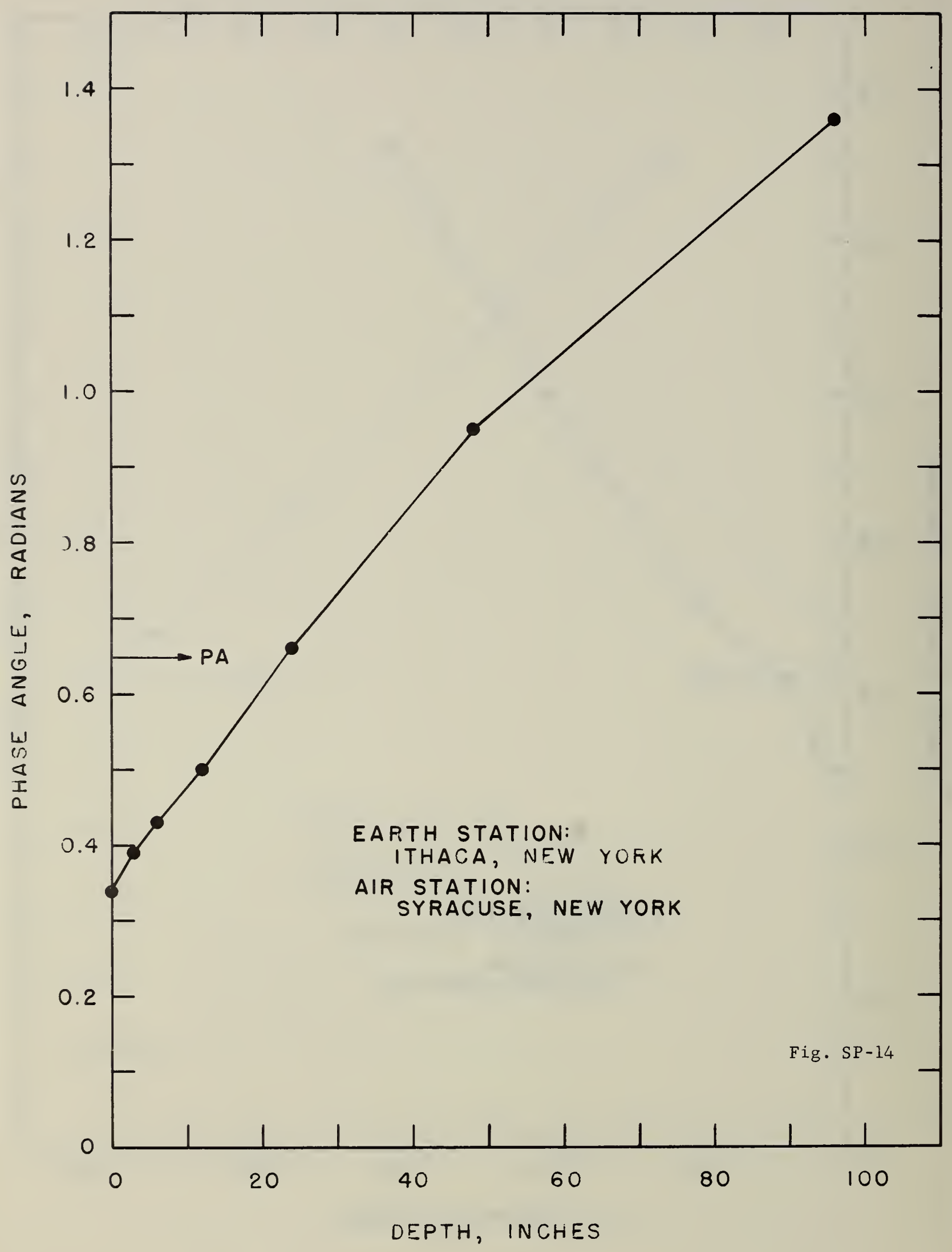




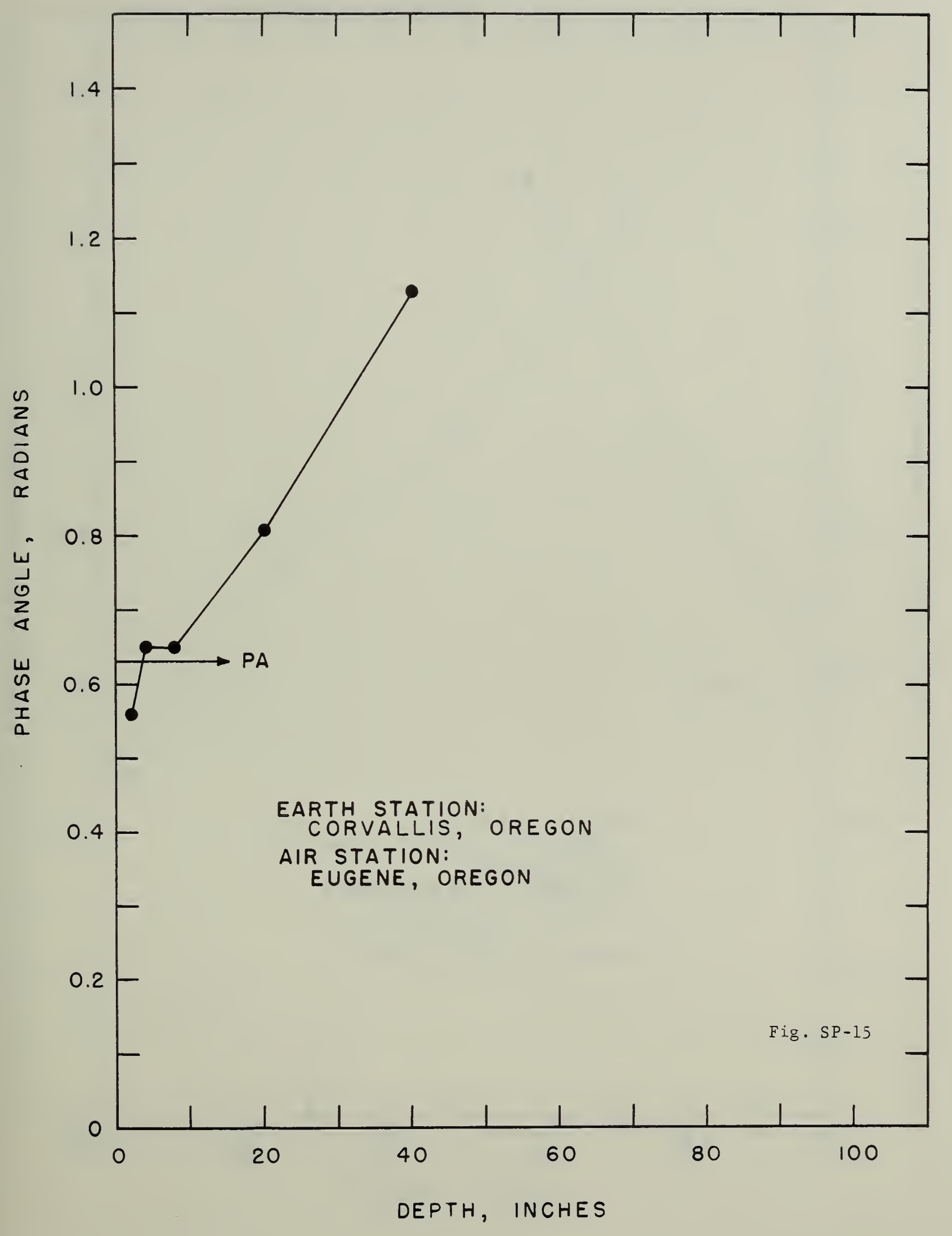




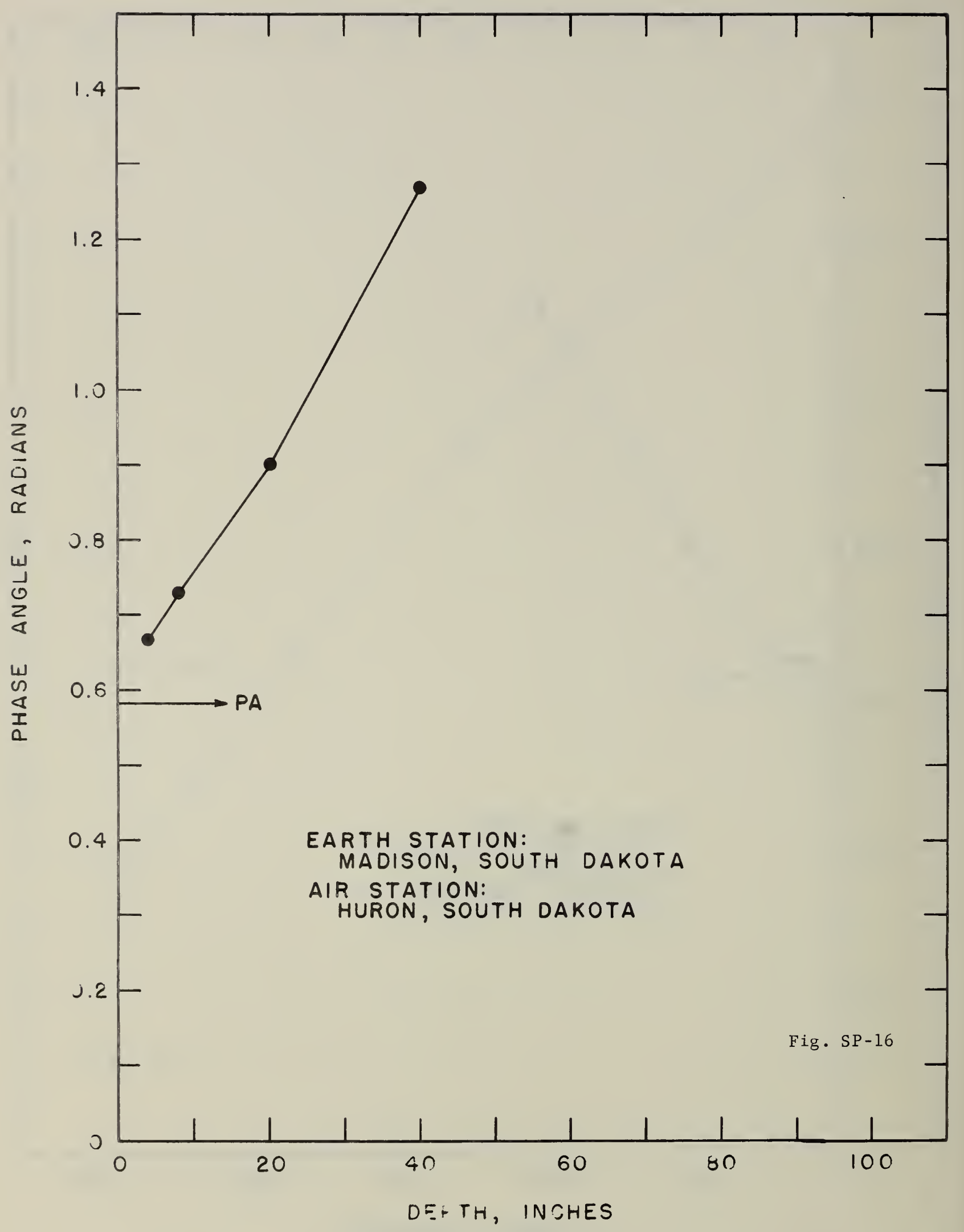




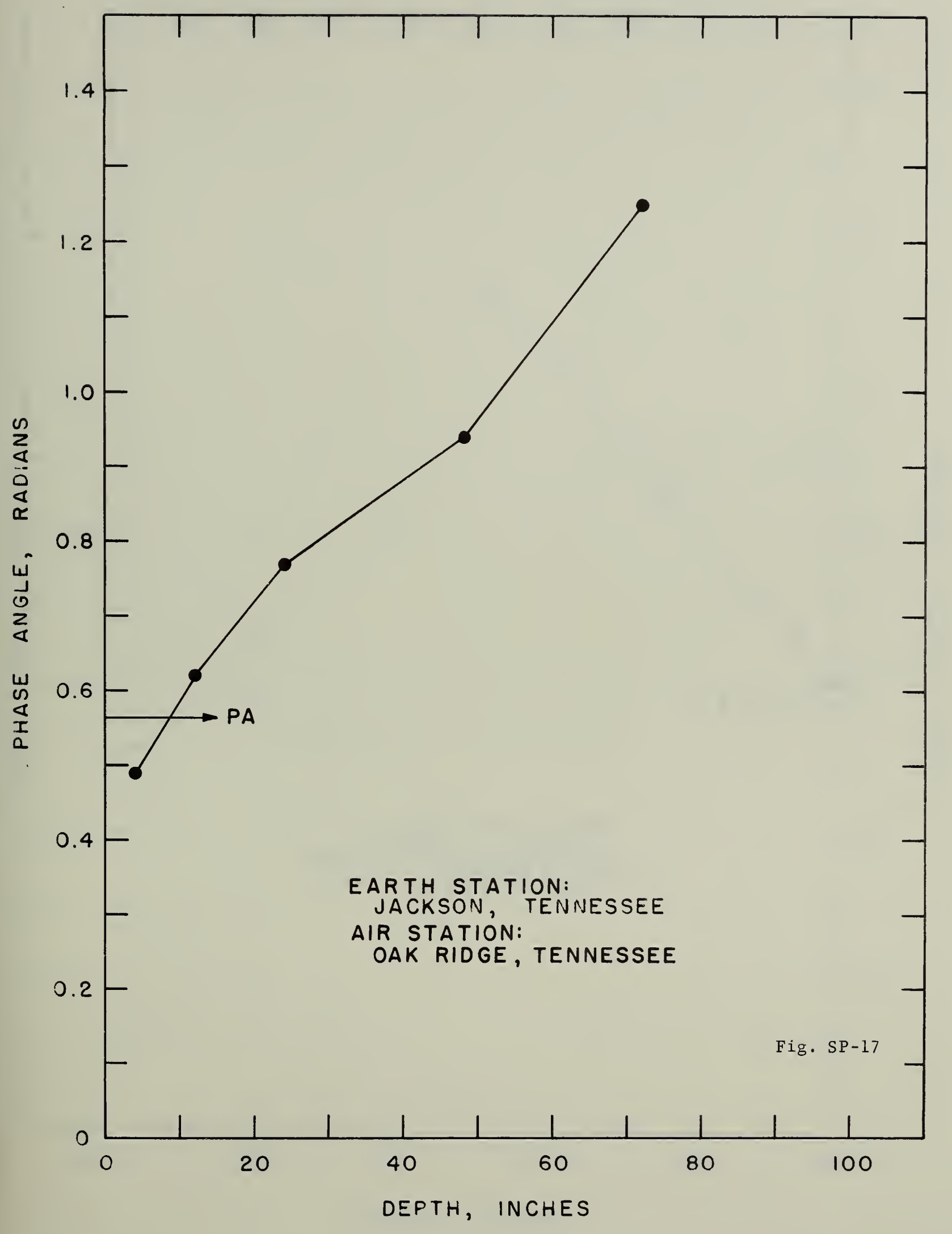




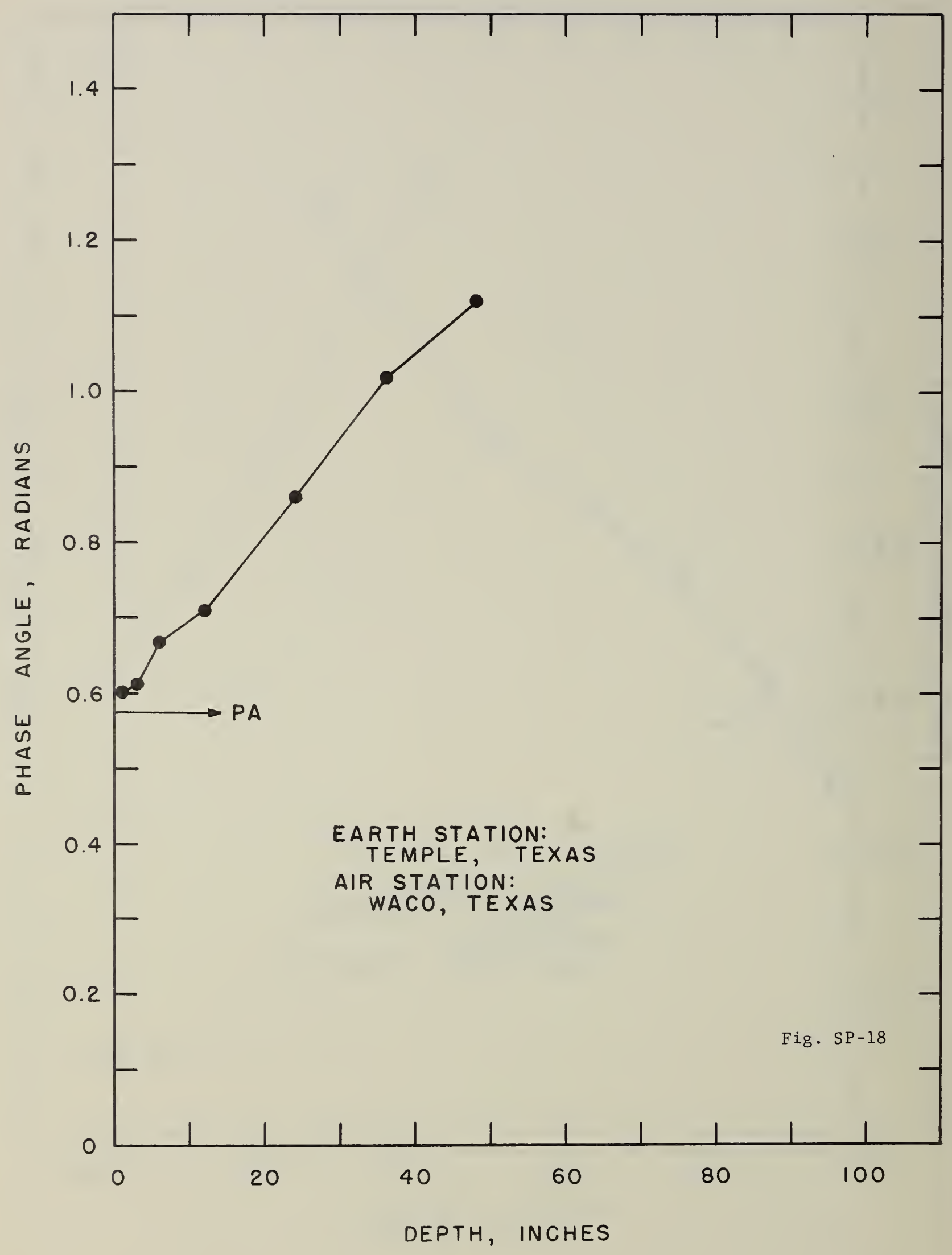




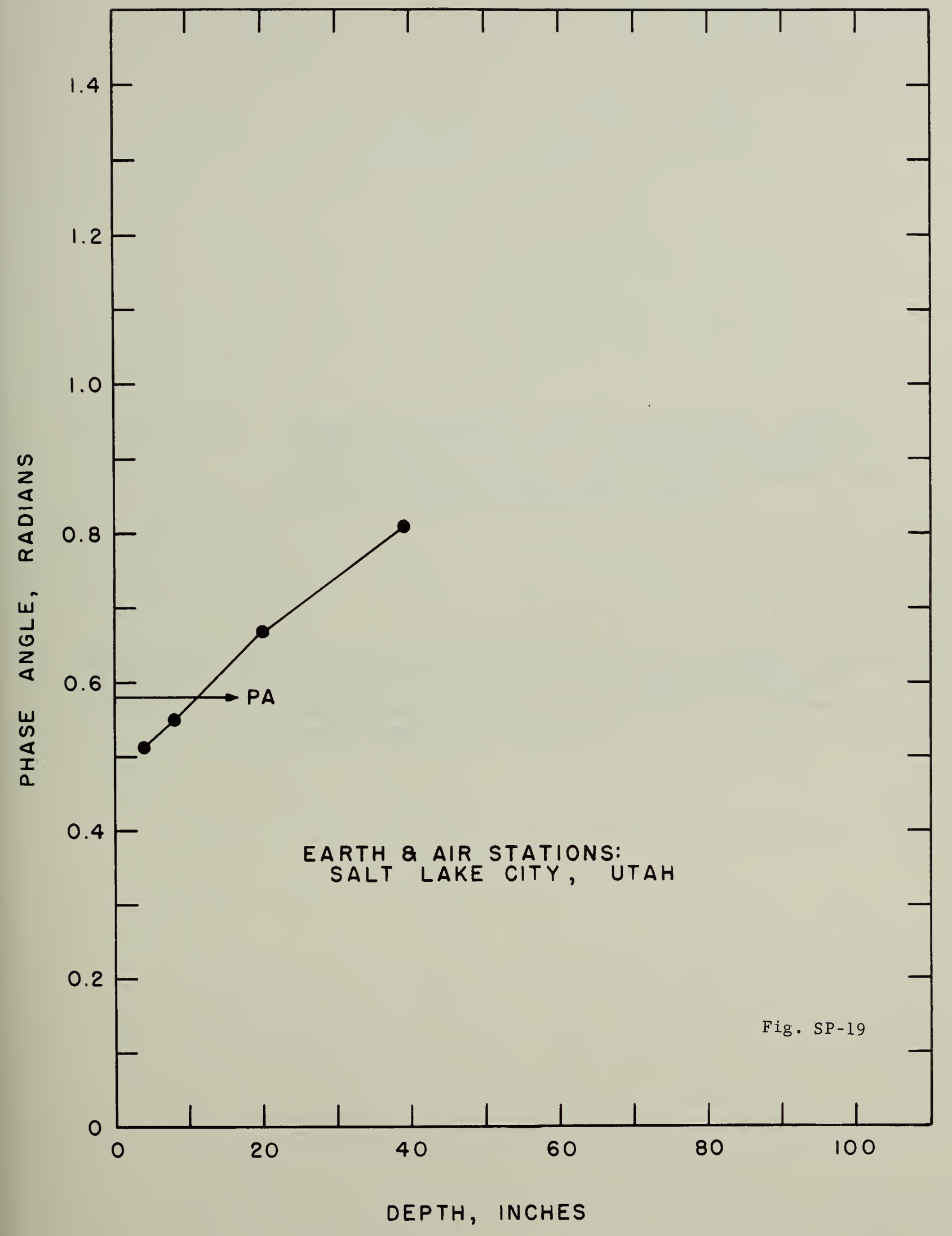



Tables ST-1 to ST -63

Tables STA-1 to STA-63
Summary of observed earth temperatures, results of least-squares analysis, and calculated earth temperatures using the least-squares constants for al1 of 63 earth temperature stations

Calculated earth temperatures for selected depths and thermal diffusivities, and integrated average temperature for upper 10-ft earth stratum for 63 earth temperature stations 

EARTH TEMPERATURE STATICN

TYPE OF SOIL

TYPE CF EARTH SURFACE

DATA PROCESSED BY

DATA SOURCE

PERIOD OF OBSERVATION
AUEURN, ALABAMA

$S T-1$

\section{OBSERVED MONTHLY AVERAGE EARTH TEMPERATURES}

\section{DEPTH BELOW}

MONTH OF YEAR

SURFACE (IN)

$\begin{array}{rrrrrrrrrrrrrrr}3.0 & 48.5 & 50.5 & 55.2 & 65.5 & 72.2 & 74.0 & 86.5 & 82.2 & 75.5 & 64.8 & 52.2 & 52.0 \\ 6.0 & 48.2 & 55.5 & 53.8 & 64.8 & 72.0 & 73.5 & 85.8 & 81.5 & 75.0 & 65.2 & 52.8 & 51.2 \\ 24.0 & 49.5 & 50.5 & 53.8 & 62.5 & 70.5 & 74.2 & 81.5 & 80.0 & 80.8 & 68.2 & 58.8 & 55.0 \\ 48.0 & 52.5 & 50.5 & 53.5 & 59.8 & 67.2 & 72.2 & 77.0 & 78.0 & 70.8 & 70.8 & 63.5 & 58.5 \\ 96.0 & 58.0 & 55.5 & 55.2 & 57.2 & 61.2 & 67.2 & 71.0 & 73.2 & 75.0 & 72.5 & 77.0 & 63.5\end{array}$

DEPTH BELOW

RESLLTS OF LEAST SQUARES ANALYSIS

SUR FACEIIN

$\triangle \operatorname{VERAGE}(A)$

AMPLITUDE (B)

PHASE ANGLE(P)

$\begin{array}{rl}3.0 & 65.0 \\ 6.0 & 65.0 \\ 24.0 & 65.5 \\ 48.0 & 64.6 \\ 96.0 & 65.6\end{array}$
17.5
16.6
16.1
12.8
10.5

C. 56

C. 56

0.77

C. 91

1.53
ST ANDARD

DEVIATION

3.0
3.4
2.0
1.7
2.6

CALCULATEC EARTH TEMPERATURES AT UBSERVED DEPTHS(*)

DEPTH BELOW

SURFACEIIN)
MONTH OF YEAR

$\begin{array}{llllllllllllll}3.0 & 48.4 & 50.7 & 56.5 & 65.0 & 73.2 & 79.4 & 81.6 & 79.4 & 73.1 & 64.9 & 56.4 & 50.5\end{array}$

$\begin{array}{llllllllllllll}6.0 & 48.7 & 50.8 & 56.4 & 64.6 & 72.7 & 78.9 & 81.3 & 79.2 & 73.2 & 65.2 & 56.9 & 51.0\end{array}$

$\begin{array}{llllllllllllll}24.0 & 50.9 & 51.8 & 56.0 & 62.8 & 70.1 & 76.1 & 79.1 & 78.3 & 73.8 & 67.1 & 59.6 & 53.8\end{array}$

$\begin{array}{lllllllllllll}48.0 & 53.6 & 53.3 & 55.9 & 61.1 & 67.2 & 72.9 & 76.3 & 76.7 & 73.9 & 68.8 & 62.5 & 57.0\end{array}$

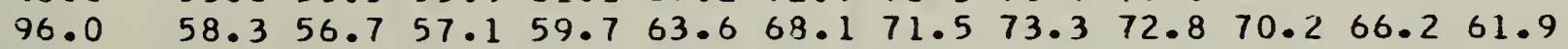


CALCULATED FARTH TEMPERATURES AT SELECTED IEPTHS

FOR DIFFUSIVITY $=0.025, A=65.0, B O=17.0$ AND $P O=0.49$

DEPTH BELOW

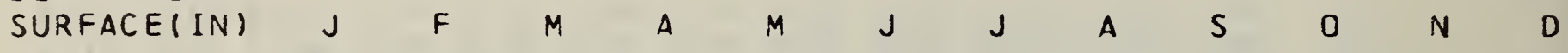

MONTH DF YEAR

\begin{tabular}{|c|c|c|c|c|c|c|c|c|c|c|c|c|}
\hline $\begin{array}{r}24.0 \\
48.0 \\
72.0 \\
96.0 \\
120.0\end{array}$ & $\begin{array}{l}51.9 \\
55.5 \\
58.5 \\
61.0 \\
62.9\end{array}$ & $\begin{array}{l}52.3 \\
54.5 \\
56.8 \\
59.0 \\
60.9\end{array}$ & $\begin{array}{l}55.9 \\
56.2 \\
57.2 \\
58.5 \\
59.9\end{array}$ & $\begin{array}{l}62.1 \\
60.4 \\
59.7 \\
59.7 \\
60.3\end{array}$ & $\begin{array}{l}68.9 \\
65.6 \\
63.5 \\
62.3 \\
61.9\end{array}$ & $\begin{array}{l}74.9 \\
70.9 \\
67.9 \\
65.7 \\
64.4\end{array}$ & $\begin{array}{l}78 \cdot 1 \\
74.4 \\
71 \cdot 3 \\
68 \cdot 8 \\
67 \cdot 0\end{array}$ & $\begin{array}{l}77.7 \\
75.5 \\
73.2 \\
71.0 \\
69.1\end{array}$ & $\begin{array}{l}73.9 \\
73.7 \\
72.7 \\
71.5 \\
70.1\end{array}$ & $\begin{array}{l}67.8 \\
69.6 \\
70.3 \\
70.2 \\
69.7\end{array}$ & $\begin{array}{l}60.7 \\
64.1 \\
66.3 \\
67.5 \\
68.0\end{array}$ & $\begin{array}{l}55.0 \\
59.0 \\
62.1 \\
64.2 \\
65.6\end{array}$ \\
\hline
\end{tabular}
INTEGRATED

AVERAGE FROM

$\begin{array}{llllllllllllllll}\text { SURFACE } & 56.5 & 55.7 & 57.2 & 60.9 & 65.6 & 70.2 & 73.4 & 74.3 & 72.7 & 69.1 & 64.2 & 59.7\end{array}$ TO $10 \mathrm{FT}$.

CALCULATED AUGUST EARTH TEMPERATURE AT SELECTED DIFFUSIVITIES AND SELECTED DEPTHS

DEPTH BELOW

SURFACE (IN)

24.0

48.0

72.0

96.0

120.0

INTEGR ATED

AVERAGE FROM

SURFACE

TO $10 \mathrm{FT}$.

\begin{tabular}{lclll}
\multicolumn{5}{c}{ DIFFUSIVITIES } \\
0.010 & 0.020 & 0.025 & 0.030 & 0.040 \\
76.5 & 77.5 & 77.7 & 77.9 & 78.2 \\
72.8 & 74.9 & 75.5 & 75.9 & 76.5 \\
69.6 & 72.4 & 73.2 & 73.8 & 74.6 \\
67.1 & 70.1 & 71.0 & 71.7 & 72.8 \\
65.6 & 68.1 & 69.1 & 79.9 & 71.1
\end{tabular}

$71 \cdot 7$

73. 7

74.3

$74 \cdot 8$

$75 \cdot 5$ 
EARTH TENPERATURE STATION

TYPE CF SOIL

TYPE CF EARTH SURFACE

DATA PROCESSED BY

DATA SOURCE

PERIOC OF OBSERVATIDN
DECATUR, ALABAMA

ST- 2

\section{GRASS}

US WEATHER R.C.

1949-1951

ORSERVED MONTHLY AVERAGE EARTH TEMPERATURES

MONTH OF YEAR

DEPTH BELOW

SURFACE( IN )

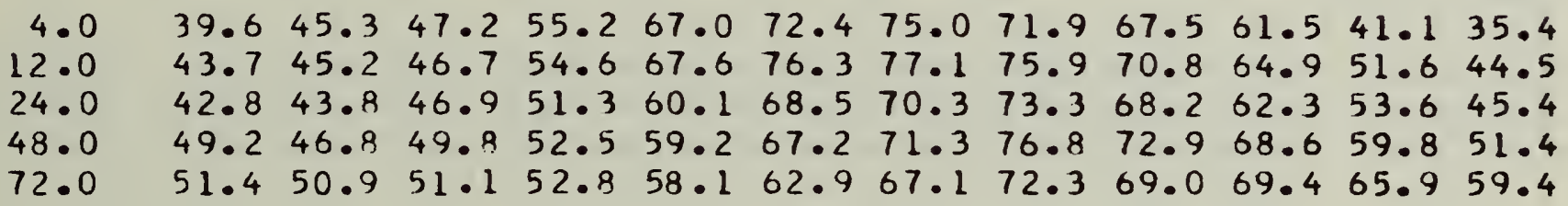

DEPTH BELOW

RESLLTS OF LEAST SQUARES ANALYSIS

SURFACE(IN) AVERAGE(A)

$\begin{array}{ll}4.0 & 56.9 \\ 12.0 & 60.1 \\ 24.0 & 57.3 \\ 48.0 & 60.6 \\ 72.0 & 61.0\end{array}$

AMPLITUOE (B)

PHASE ANGLE(P)

$18 \cdot 7$
$18 \cdot 0$
$15 \cdot 1$
$14 \cdot 1$
10.8
STANDARD

DEVIATION

$3 \cdot 9$
$3 \cdot 6$
$3 \cdot 0$
3.6
$3 \cdot 0$

CALCULATED EARTH TEMPERATURES AT OBSERVED DEPTHS(*)

DEPTH BELOW

SURFACE (IN)
MONTH OF YEAR

\begin{tabular}{|c|c|c|c|c|c|c|c|c|c|c|c|c|}
\hline $\begin{array}{r}4.0 \\
12.0 \\
24.0 \\
48.0 \\
72.0\end{array}$ & $\begin{array}{l}39.8 \\
41.3 \\
43.6 \\
47.8 \\
51.5\end{array}$ & $\begin{array}{l}42.7 \\
43.3 \\
44.4 \\
46.7 \\
49.6\end{array}$ & $\begin{array}{l}49.6 \\
49.1 \\
48.7 \\
49.0 \\
50.1\end{array}$ & $\begin{array}{l}59.4 \\
57.9 \\
56.1 \\
53.9 \\
53.0\end{array}$ & $\begin{array}{l}68.8 \\
66.8 \\
64.1 \\
60.0 \\
57.4\end{array}$ & $\begin{array}{l}75.8 \\
73.8 \\
70.9 \\
66.0 \\
62.4\end{array}$ & $\begin{array}{l}78.2 \\
76.6 \\
74.3 \\
70.0 \\
66.3\end{array}$ & $\begin{array}{l}75.4 \\
74.8 \\
73.7 \\
71.1 \\
68.4\end{array}$ & $\begin{array}{l}68.0 \\
68.5 \\
69.0 \\
68.8 \\
67.8\end{array}$ & $\begin{array}{l}58.4 \\
59.9 \\
61.8 \\
64.0 \\
64.9\end{array}$ & $\begin{array}{l}48.8 \\
50.8 \\
53.6 \\
57.7 \\
60.3\end{array}$ & $\begin{array}{l}42.1 \\
44.2 \\
47.0 \\
51.9 \\
55.5\end{array}$ \\
\hline
\end{tabular}


CALCULATEC FARTH TEMPERATURES AT SELECTED CEPTHS

FOR DIFFUSIVITY $=0.025, A=59.0, B O=21.0$ AND $P O=0.45$

DEPTH BELOW

SURFACE(IN)

MONTH OF YEAR

$\begin{array}{llllllllllll} & & & & & & & & & & & \end{array}$

$24.0 \quad 42.7 \quad 43.5 \quad 48.2 \quad 56.1 \quad 64.5 \quad 71.7 \quad 75.3 \quad 74.5 \quad 69.5 \quad 61.8 \quad 53.1 \quad 46.2$ $\begin{array}{llllllllllllll}48.0 & 47.0 & 46.1 & 48.4 & 53.7 & 60.3 & 66.7 & 70.9 & 71.9 & 69.4 & 64.2 & 57.4 & 51.2\end{array}$ $\begin{array}{lllllllllllll}12.0 & 50.8 & 48.8 & 49.5 & 52.8 & 57.6 & 62.9 & 67.1 & 69.2 & 68.4 & 65.2 & 60.2 & 55.0\end{array}$ $\begin{array}{lllllllllllll}96.0 & 53.8 & 51.5 & 51.0 & 52.7 & 56.0 & 60.2 & 64.0 & 66.5 & 66.9 & 65.2 & 61.8 & 57.7\end{array}$ $\begin{array}{llllllllllllll}120.0 & 56.2 & 53.8 & 52.7 & 53.3 & 55.3 & 59.5 & 61.6 & 64.2 & 65.3 & 64.7 & 62.5 & 59.5\end{array}$ INTEGRATED AVERAGE FROM SURFACE
TO $10 \mathrm{FT}$. $\begin{array}{llllllllllll}48.3 & 47.5 & 49.6 & 54.3 & 60.1 & 65.8 & 69.6 & 70.5 & 68.2 & 63.6 & 57.6 & 52.1\end{array}$ CALCULATED AUGUST EARTH TEMPERATURE AT SELECTED DIFFUSIVITIES AND SELECTEN DEPTHS

DEPTH BELOW

SURFACFIIN)

$$
\begin{array}{r}
24.0 \\
48.0 \\
72.0 \\
96.0 \\
120.0
\end{array}
$$

INTEGRATED

AVERAGE FROM

SURFACE

IO $10 \mathrm{FT}$.

\begin{tabular}{lclll}
\multicolumn{5}{c}{ DIFFUSIVITIES } \\
0.010 & 0.020 & 0.025 & 0.030 & 0.040 \\
73.1 & 74.2 & 74.5 & 74.7 & 75.0 \\
68.7 & 71.3 & 71.9 & 72.4 & 73.1 \\
64.8 & 68.2 & 69.2 & 69.9 & 70.9 \\
61.9 & 65.4 & 66.5 & 67.4 & 68.7 \\
59.8 & 63.0 & 64.2 & 65.2 & 66.6
\end{tabular}

$67 \cdot 3$

69.8

70.5

$71 \cdot 1$

71.9 
EARTH TEMPERATURE STATION

TYPE OF SOIL

TYPE OF EARTH SURFACE

DATA PROCESSED BY

DATA SOURCE

PERICC OF OBSERVATIONN
TEMPE, AR I ZONA

$S T-3$

SANDY SOIL

CI TRUS GROVE

US WEATHER R.C.

$1957-1959$

OBSERVED MONTHLY AVERAGE EARTH TEMPERATURES

MONTH OF YEAR

UEPTH BELOW

SURFACE (IN)

$49.7 \quad 53.3$

60.6

$\begin{array}{llllllllll}68.9 & 73.8 & 81.9 & 86.4 & 86.8 & 78.7 & 68.9 & 55.5 & 50.1\end{array}$

$\begin{array}{lllllllllllll}20.0 & 54.0 & 56.1 & 62.5 & 69.0 & 74.3 & 81.5 & 86.4 & 87.1 & 82.6 & 73.4 & 62.0 & 55.9\end{array}$

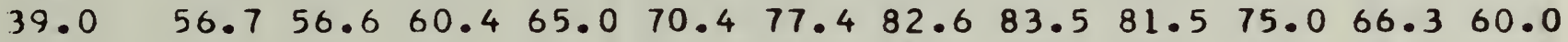

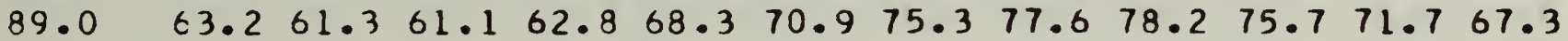

DEPTH BELOW

SURFACE(IN) AVERACF(A)

$\begin{array}{rr}8.0 & 68.0 \\ 20.0 & 70.5 \\ 39.0 & 69.7 \\ 89.0 & 69.5\end{array}$

AMPLITUDE (B)

PHASE ANGLE (P)

$$
\begin{array}{r}
18.6 \\
16.4 \\
13.7 \\
8.6
\end{array}
$$

C. 53

0.66

C. 88

1.32
STANDARD

DEVIATION

2.5

1.9

1.1

1.3

CALCULATEC EARTH TEMPERATURES AT OBSERVEO CEPTHS(*)

DEPTH BELDW

MONTH OF YEAR

SURFACE (IN)

8.0

51.553 .8

$F \quad M$

A M J

$\begin{array}{llllll}\text { J A } & \text { S } & 0 & \text { N } & \text { D }\end{array}$

20.0

$53.754 .759 .6 \quad 67.5$

$78.6 \quad 8$

$\begin{array}{lllllll}85.7 & 88.5 & 86.3 & 79.6 & 70.5 & 61.0 & 54.2\end{array}$

39.0

$57.0 \quad 56.6 \quad 59.5 \quad 65.5$

78.6

$\begin{array}{llllllllll}9 & 82.9 & 86.3 & 85.3 & 80.1 & 72.3 & 63.7 & 57.0\end{array}$

89.0

$64.161 .9 \quad 61.7 \quad 63.8 \quad 67.5 \quad 71.975 .7 \quad 78.178 .2$

74.467 .260 .9

76.172 .368 .0

(*) basic parameters USED for the calculation

$A=70.0, B D=20.0, P O=0.47, D=.027$ 
CALCULATEC FARTH TEMPERATURES AT SELECTED LEPTHS

FOR DIFFUSIVITY $=0.025, A=70.0, B O=20.0$ AND $P O=0.47$

MONTH OF YEAR

DEPTH BELOW

SURFACE (IN)

24.0
48.0
72.0
96.0
120.0

$\begin{array}{llllllllllllll}54.5 & 55.2 & 59.5 & 66.9 & 74.9 & 81.9 & 85.4 & 84.9 & 80.2 & 73.0 & 64.7 & 58.1\end{array}$

$\begin{array}{llllllllllllll}58.7 & 57.7 & 59.8 & 64.8 & 71.0 & 77.1 & 81.2 & 82.3 & 80.0 & 75.1 & 68.7 & 62.8\end{array}$

$\begin{array}{llllllllllllll}62.3 & 60.3 & 60.9 & 63.9 & 68.4 & 73.6 & 77.6 & 79.6 & 79.0 & 76.0 & 71.3 & 66.4\end{array}$

$65.2 \quad 62.7 \quad 62.4 \quad 63.9 \quad 67.0 \quad 71.0 \quad 74.6 \quad 77.1 \quad 77.6 \quad 76.0 \quad 72.8 \quad 68.9$

$120.0 \quad 67.4 \quad 65.1 \quad 64.0 \quad 64.5 \quad 66.4 \quad 69.4 \quad 72.4 \quad 74.9 \quad 76.0 \quad 75.5 \quad 73.5 \quad 70.6$ INTEGRATED

AVERAGE FROM

SURFACE

$59.959 .0 \quad 60.965 .3 \quad 70.976 .3 \quad 80.0 \quad 81.0 \quad 78.9 \quad 74.6 \quad 68.8 \quad 63.6$ TO $10 \mathrm{FT}$.

CALCULATED AUGUST EARTH TEMPERATURE AT SELECTED DIFFUSIVITIES AND SELECTED DEPTHS

DEPTH BELOW

SURFACE (IN)

INTEGRATED

24.0

48.0

72.0

96.0

120.0

AVERAGE FROM

SURFACE

TO $10 \mathrm{FT}$.

\begin{tabular}{lclll}
\multicolumn{5}{c}{ DIFFUSIVITIES } \\
0.010 & 0.020 & 0.025 & 0.030 & 0.040 \\
83.4 & 84.6 & 84.9 & 85.1 & 85.4 \\
79.2 & 81.7 & 82.3 & 82.8 & 83.4 \\
75.4 & 78.7 & 79.6 & 80.3 & 81.3 \\
72.6 & 76.0 & 77.1 & 78.0 & 79.2 \\
70.7 & 73.8 & 74.9 & 75.8 & 77.2
\end{tabular}

77.9

80.3

81.0

81.5

82.3 
EARTH TEMPERATURE STATIUN

TYPE OF SOIL

TYPF OF EARTH SURFACE

DATA PROCESSED BY

DATA SOURCE

PERIOD OF OESERVATION
TUCSON, ARI ZONA

$S T-4$

$B A R E$

JEN-HU-CHANG

REFERENCE (5)

$19 \subseteq 8$

$1937-1938$

OBSERVFO MONTHLY AVERAGE EARTH TEMPERATURES

DEPTH BELOW

MONTH DF YEAR

SURFACE(IN)

$\begin{array}{lllllllllllllll}3.0 & 53.6 & 53.9 & 61.2 & 75.6 & 83.2 & 85.3 & 80.3 & 81.1 & 79.8 & 77.0 & 65.5 & 53.5\end{array}$

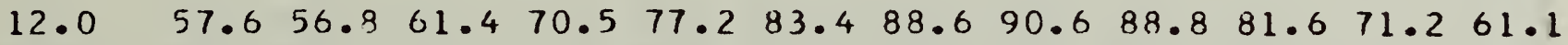

$\begin{array}{llllllllllllll}24.0 & 62.8 & 61.8 & 65.3 & 70.2 & 76.2 & 81.4 & 86.0 & 88.1 & 87.4 & 81.8 & 74.3 & 65.8\end{array}$

$\begin{array}{lllllllllllllll}72.0 & 64.7 & 62.5 & 63.4 & 65.5 & 70.9 & 75.6 & 79.1 & 82.2 & 83.0 & 81.0 & 75.4 & 68.8\end{array}$

DEPTH BELOW

RESULTS OF LEAST SQUARES ANALYSIS

SURFACE(IN)

AVERAGF (A)

AMPL I TUDE (B)
16.0
$17 \cdot 1$
13.2
10.3

\section{PHASE ANGLE(P)}

C. 52

C. 87

0.96

1.28
STANDARD

DEVIATION

4.4
1.5
1.1
0.8

CALCULATEC FARTH TEMPERATURES AT OBSERVED DEPTHS(*)

DEPTH BELOW

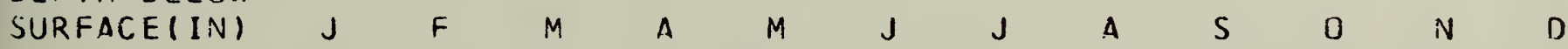

MONTH OF YEAR

$\begin{array}{lllllllllllllllll}3.0 & 58.0 & 58.0 & 6.2 .2 & 70.1 & 79.1 & 87.2 & 91.9 & 92.0 & 87.5 & 79.7 & 70.5 & 62.7\end{array}$

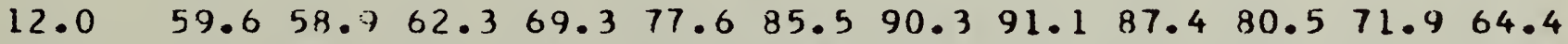

$24.0 \quad 61.5 \quad 60.2 \quad 62.6 \quad 68.5 \quad 76.0 \quad 83.4 \quad 88.3 \quad 89.8 \quad 87.1 \quad 81.4 \quad 73.6 \quad 66.5$

$\begin{array}{lllllllllllllll}72.0 & 68.1 & 65.4 & 65.1 & 67.5 & 71.8 & 77.1 & 81.7 & 84.6 & 84.8 & 82.4 & 77.9 & 72.8\end{array}$

(*) BASIC PARAMETERS USED for the CALCULATION

$A=75.0, B O=18.0, P O=0.77, D=.039$ 
CALCULATED EARTH TEMPERATURES AT SELECTED CEPTHS

FOR DIFFUSIVITY $=0.025, A=75.0, B O=18.0$ AND $P D=0.77$

DEPTH BELOW

SURFACEIIN

MONTH OF YEAR

$\begin{array}{llllllllllll} & & & & & & & & & & & \end{array}$

$\begin{array}{rllllllllllll}24.0 & 62.4 & 60.8 & 62.8 & 68.2 & 75.3 & 82.4 & 87.4 & 89.2 & 87.0 & 81.7 & 74.4 & 67.5 \\ 48.0 & 66.6 & 64.1 & 64.4 & 67.5 & 72.6 & 78.4 & 83.2 & 85.9 & 85.6 & 82.4 & 77.5 & 71.5 \\ 72.0 & 69.9 & 67.1 & 66.2 & 67.7 & 71.1 & 75.6 & 79.9 & 82.9 & 83.7 & 82.2 & 78.7 & 74.3 \\ 96.0 & 72.5 & 69.6 & 68.2 & 68.5 & 70.6 & 73.9 & 77.4 & 80.3 & 81.8 & 81.5 & 79.3 & 76.1 \\ 120.0 & 74.3 & 71.7 & 70.0 & 69.6 & 70.6 & 72.9 & 75.6 & 78.3 & 80.0 & 80.4 & 79.3 & 77.1\end{array}$
INTEGRATED AVERAGE FROM

SURFACE

$67.5 \quad 65.3 \quad 65.5 \quad 68.3 \quad 72.8 \quad 78.1 \quad 82.3 \quad 84.7 \quad 84.4 \quad 81.6 \quad 76.971 .9$ TO $10 \mathrm{FT}$.

\section{CALCULATED AUgUST EARTH TEMPERATURE AT SELECTED DIFFUSIVITIES} AND SELECTED DEPTHS

DEPTH BELOW

SURFACE (IN)

24.0
48.0
72.0
96.0
20.0

INTEGRA TED

AVERAGE FROM

SURFACE

TO $10 \mathrm{FT}$.
DIFFUSIVITIES

$\begin{array}{lllll}0.010 & 0.020 & 0.025 & 0.030 & 0.040 \\ 87.3 & 88.8 & 89.2 & 89.4 & 89.8 \\ 82.5 & 85.2 & 85.9 & 86.5 & 87.3 \\ 78.7 & 81.9 & 82.9 & 83.7 & 84.8 \\ 76.3 & 79.3 & 80.3 & 81.2 & 82.5 \\ 74.9 & 77.3 & 78.3 & 79.1 & 80.4\end{array}$

$81 \cdot 6$

84.0

84.7

85.3

86.1 
EARTH TEMPERATURE STATION

TYPE OF SOIL

TYPE CF EARTH SURFACE

DATA PROCESSED BY

DATA SOURCE

PERIOC OF OBSERVATION
BRAWLEY, CAL IFORNIA

$S T-5$

SILTY CLAY

BARE

CLIMATOLOGICAL DATA

$1960-1962$

\section{OBSERVED NONTHLY AVERAGE EARTH TEMPERATURES}

DEPTH BELUW

SURFACE (IN)

MONTH OF YEAR

$\begin{array}{rrrrrrrrrrrrrrr}4.0 & 49.5 & 55.7 & 62.8 & 74.4 & 78.9 & 88.2 & 93.6 & 94.2 & 88.3 & 76.1 & 63.0 & 52.8 \\ 8.0 & 55.8 & 60.5 & 65.9 & 76.0 & 80.6 & 89.2 & 95.6 & 96.4 & 91.1 & 81.8 & 69.2 & 60.0 \\ 12.0 & 59.2 & 62.9 & 67.7 & 77.0 & 81.3 & 89.8 & 96.0 & 97.3 & 93.0 & 83.6 & 72.6 & 63.6 \\ 20.0 & 61.5 & 64.1 & 67.9 & 76.1 & 80.6 & 87.7 & 93.6 & 95.6 & 92.6 & 85.0 & 75.4 & 66.7 \\ 39.0 & 65.5 & 65.9 & 67.6 & 73.2 & 77.5 & 82.5 & 88.3 & 91.2 & 90.5 & 85.8 & 79.1 & 71.5 \\ 79.0 & 72.8 & 70.9 & 70.9 & 72.8 & 75.7 & 78.7 & 82.7 & 86.0 & 87.2 & 86.1 & 82.6 & 77.8\end{array}$

DEPTH BELOW

RESLLTS OF LEAST SQUARES ANALYSIS

SURFACE (IN)

AVERAGE (A)

73.2
76.9
78.8
79.0
78.2
78.7
AMPLITUDE (B)

$$
\begin{array}{r}
21 \cdot 5 \\
19.4 \\
18 \cdot 2 \\
16 \cdot 3 \\
12.8 \\
8.3
\end{array}
$$

STANDARD DEVIATION

3.0
2.6
2.3
1.9
1.5
0.8

CALCULATEC EARTH TEMPERATURES AT OBSERVED DEPTHS(*)

DEPTH BELOW

$\begin{array}{lllllllllllll}\text { SURFACEIIN) J } & F & M & A & M & J & J & A & S & 0 & N & D\end{array}$

$\begin{array}{lllllllllllllll}4.0 & 60.0 & 61.4 & 67.2 & 76.5 & 86.1 & 94.2 & 97.9 & 96.6 & 90.4 & 81.4 & 71.4 & 63.7\end{array}$

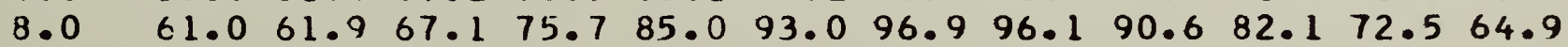

$\begin{array}{lllllllllllllll}12.0 & 61.9 & 62.4 & 67.0 & 75.1 & 84.0 & 91.8 & 96.0 & 95.6 & 90.7 & 82.7 & 73.6 & 66.1\end{array}$

$\begin{array}{llllllllllllll}20.0 & 63.8 & 63.5 & 67.0 & 74.0 & 82.2 & 89.6 & 94.1 & 94.6 & 90.7 & 83.8 & 75.4 & 68.2\end{array}$

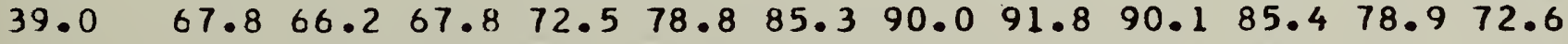

$\begin{array}{lllllllllllll}79.0 & 74.4 & 71.7 & 70.9 & 72.2 & 75.3 & 79.5 & 83.4 & 86.2 & 87.1 & 85.7 & 82.5 & 78.5\end{array}$ 


\section{CALCULATEC EARTH TEMPERATURES AT SELECTED DEPTHS}

FOR DIFFUSIVITY $=0.025, A=79.0, B O=20 . C$ AND $P O=0.60$

DEPTH BELOW

MONTH OF YEAR

SURFACE(IN)

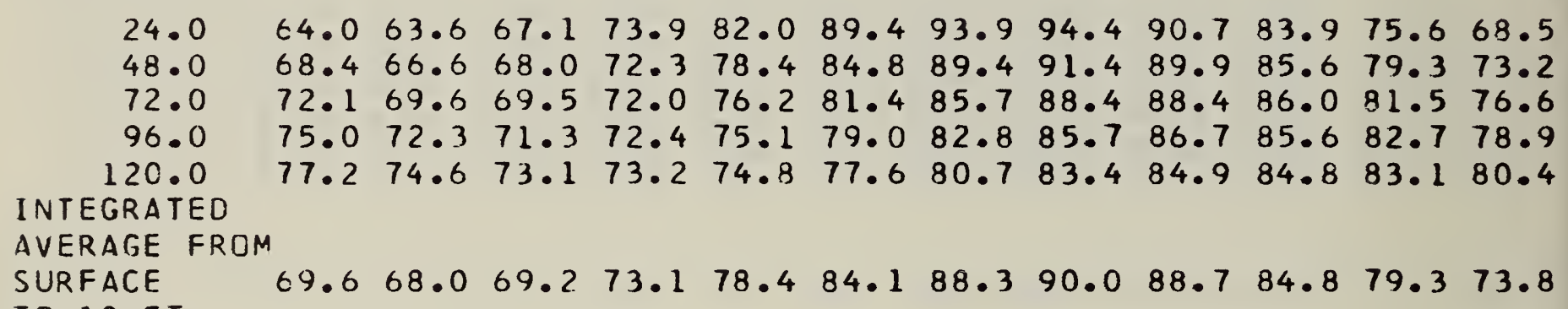

CALCULATED AUGUST EARTH TEMPERATURE AT SELECTED DIFFUSIVITIES AND SELECTED DEPTHS

DEPTH BELOW

SURFACE(IN)

24.0
48.0
72.0
96.0
120.0

INTEGRATED

AVERAGE FROM

SURFACE

TO $10 \mathrm{FT}$.

\begin{tabular}{lllll}
\multicolumn{5}{c}{ DIFFUSIVITIES } \\
0.010 & 0.020 & 0.025 & 0.030 & 0.040 \\
92.7 & 94.1 & 94.4 & 94.7 & 95.0 \\
87.9 & 90.7 & 91.4 & 91.9 & 92.7 \\
83.9 & 87.4 & 88.4 & 89.1 & 90.2 \\
81.1 & 84.5 & 85.7 & 86.6 & 87.9 \\
79.4 & 82.3 & 83.4 & 84.3 & 85.8
\end{tabular}

86.7

89.3

90.0

90.6

91.5 
OBSERVED NONTHLY AVERAGE EARTH TEMPERATURES

\section{DEPTH BELDW}

SURFACE (IN)

$$
\text { MONTH OF YEAR }
$$

$\begin{array}{rlllllllll}0.5 & 48.0 & 51.1 & 58.4 & 63.2 & 74.8 & 82.0 & 90.6 & 86.0 & 77.4 \\ 3.0 & 48.2 & 47.9 & 55.2 & 61.9 & 72.9 & 78.9 & 86.6 & 83.2 & 76.4 \\ 6.0 & 48.8 & 50.2 & 54.5 & 60.9 & 72.0 & 78.0 & 87.2 & 84.5 & 79.4 \\ 12.0 & 48.5 & 50.2 & 53.7 & 60.2 & 70.8 & 76.4 & 84.4 & 83.0 & 77.2 \\ 24.0 & 53.2 & 51.9 & 54.6 & 59.7 & 68.4 & 72.9 & 82.8 & 82.8 & 78.2 \\ 36.0 & 51.2 & 51.4 & 54.3 & 60.1 & 68.8 & 72.9 & 80.8 & 82.5 & 78.6\end{array}$

RESLLTS OF LEAST SOUARES ANALYSIS DEPTH BELOW SURFACE (IN)

\author{
AVERAGE (A)
}

$$
\begin{aligned}
& 67.9 \\
& 66.2 \\
& 67.0 \\
& 65.9 \\
& 66.9 \\
& 66.3
\end{aligned}
$$

AMPLITUDE (B)

$$
\begin{aligned}
& 19.4 \\
& 19.2 \\
& 18.3 \\
& 17.4 \\
& 15.2 \\
& 15.4
\end{aligned}
$$

PHASE ANGLE(P)

C. 63

0.67

C. 79

0.78

C.97

0.93
STANDARD

DEVIATION

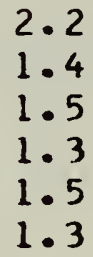


CALCULATED EARTH TEMPERATURES AT SELECTED CEPTHS

FOR DIFFUSIVITY $=0.025, A=66.0, B D=19.0$ AND $P D=0.63$

DEPTH BELOW

SURFACE (IN)

MONTH OF YEAR
24.0
48.0
72.0
96.0
120.0
$51.951 .3 \quad 54.4 \quad 60.8$
INTEGRATED
AVERAGE FROM
SURFACE
$\begin{array}{llllllllllll}57.2 & 55.5 & 56.5 & 60.1 & 65.2 & 70.6 & 74.6 & 76.4 & 75.4 & 71.8 & 66.6 & 61.3\end{array}$
TO $10 \mathrm{FT}$.
$68.475 .580 .080 .7 \quad 77.471 .163 .356 .4$ $\begin{array}{lllllllll} & 63.1 & 68.0 & 72.2 & 74.8 & 75.0 & 72.8 & 68.7 & 64.0\end{array}$ $62.165 .8 \quad 69.4 \quad 72.273 .3 \quad 72.4 \quad 69.7 \quad 66.1$

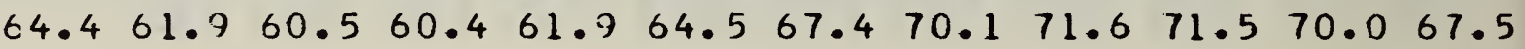

A $M$

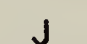

J A S

$0 \quad N$

D

CALCULATEC AUGUST EARTH TEMPERATURE AT SELECTED DIFFUSIVITIES AND SELECTEN DEPTHS

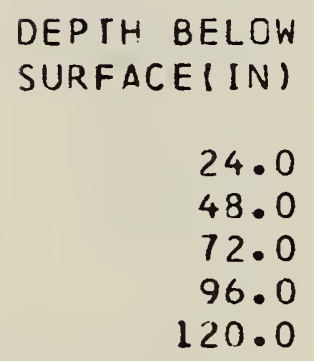

24.0

48.0

72.0

96.0

120.0

INTEGRATED

AVERAGE FROM

SURFACE

TO $10 \mathrm{FT}$.

\begin{tabular}{lclll}
\multicolumn{5}{c}{ CIFFUSIVITIES } \\
0.010 & 0.020 & 0.025 & 0.030 & 0.040 \\
79.0 & 80.4 & 80.7 & 81.0 & 81.3 \\
74.4 & 77.0 & 77.7 & 78.3 & 79.0 \\
70.6 & 73.9 & 74.8 & 75.6 & 76.6 \\
67.9 & 71.1 & 72.2 & 73.1 & 74.4 \\
66.3 & 69.0 & 70.1 & 70.9 & 72.3
\end{tabular}

73.3

75.7

76.4

77.0

77.8 
EARTH TEMPERATURE STATION

TYPE CF SOIL

TYPE OF EARTH SURFACF

DATA PROCESSED BY

DATA SOURCE

PERIOD OF OESERVATION
FT. COLLINS, COLO.

UNKNOWN

UNKNOWN

E.N.FITTON

REFERENCE (4)

$18 \& 9-1927$

OESERVED MONTHLY AVERAGE EARTH TEMPERATURES

\section{DEPTH BELOW}

SURFACE (IN)
MONTH OF YEAR

$\begin{array}{rllllllllllll}3.0 & 27.7 & 29.6 & 36.5 & 46.0 & 56.5 & 66.7 & 71.4 & 69.3 & 61.1 & 48.3 & 36.7 & 29.7 \\ 6.0 & 29.3 & 30.6 & 37.1 & 47.4 & 56.6 & 67.0 & 71.9 & 70.4 & 62.8 & 50.8 & 39.0 & 30.2 \\ 12.0 & 32.8 & 31.1 & 36.6 & 45.5 & 55.8 & 65.5 & 70.9 & 70.1 & 63.7 & 52.3 & 40.7 & 33.2 \\ 24.0 & 32.9 & 32.7 & 36.8 & 45.3 & 53.3 & 62.5 & 68.5 & 68.8 & 64.0 & 54.4 & 43.7 & 36.5 \\ 36.0 & 35.4 & 32.6 & 37.1 & 43.6 & 51.1 & 59.1 & 65.2 & 66.6 & 63.4 & 55.5 & 46.0 & 38.9 \\ 72.0 & 42.5 & 40.5 & 40.8 & 44.2 & 48.8 & 54.2 & 59.2 & 61.8 & 62.0 & 58.0 & 52.1 & 46.5\end{array}$

RESULTS OF LEAST SQUARES ANALYSIS DEPTH BELOW SURFACE(IN) AVERAGE(A)

$\begin{array}{rr}3.0 & 48.4 \\ 6.0 & 49.5 \\ 12.0 & 50.0 \\ 24.0 & 50.0 \\ 36.0 & 49.6 \\ 72.0 & 50.9\end{array}$

AMPLITUDE (B)

$$
\begin{aligned}
& 22.1 \\
& 21.9 \\
& 20.4 \\
& 18.6 \\
& 16.6 \\
& 10.9
\end{aligned}
$$

STANDARD DEVIATION
1.2
1.2
1.5
0.9
0.8
0.5 
CALCULATEC EARTH TEMPERATURES AT SELECTED DEPTHS

FOR DIFFUSIVITY $=0.025, A=50.0, B O=24.0$ ANO $P O=0.54$

\section{DEPTH BELOW}

SURFACE (IN)

$$
\text { MONTH OF YEAR }
$$

$\begin{array}{rlllllllllllll}24.0 & 31.7 & 31.8 & 36.4 & 45.0 & 54.7 & 63.3 & 68.2 & 68.2 & 63.2 & 54.8 & 44.9 & 36.6 \\ 48.0 & 36.9 & 35.1 & 37.2 & 42.8 & 50.1 & 57.7 & 63.0 & 64.9 & 62.6 & 57.1 & 49.5 & 42.2 \\ 72.0 & 41.2 & 38.6 & 38.8 & 42.1 & 47.3 & 53.5 & 58.6 & 61.4 & 61.1 & 57.9 & 52.4 & 46.4 \\ 96.0 & 44.8 & 41.7 & 40.8 & 42.3 & 45.8 & 50.6 & 55.0 & 58.3 & 59.2 & 57.6 & 54.0 & 49.3 \\ 120.0 & 47.4 & 44.4 & 42.9 & 43.2 & 45.3 & 48.7 & 52.4 & 55.6 & 57.1 & 56.8 & 54.6 & 51.2\end{array}$
INTEGRATED

AVERAGE FROM

SURFACE

$38.3 \quad 36.8 \quad 38.6 \quad 43.6 \quad 50.1 \quad 56.8 \quad 61.5 \quad 63.2 \quad 61.2 \quad 56.3 \quad 49.5 \quad 43.1$

TC $10 \mathrm{FT}$.

CALCULATED AUGUST EARTH TEMPERATURE AT SELECTED DIFFUSIVITIES AND SELECTED DEPTHS

DEPTH BELOW

SURFACE(IN)

$$
\begin{array}{r}
24.0 \\
48.0 \\
72.0 \\
96.0 \\
120.0
\end{array}
$$

INTEGRATED

AVERAGE FROM

SURFACE

TO $10 \mathrm{FT}$.

\begin{tabular}{lclll}
\multicolumn{5}{c}{ DIFFUSIVITIES } \\
0.010 & 0.020 & 0.025 & 0.030 & 0.040 \\
66.3 & 67.9 & 68.2 & 68.5 & 68.9 \\
60.9 & 64.0 & 64.9 & 65.5 & 66.3 \\
56.2 & 60.3 & 61.4 & 62.3 & 63.6 \\
52.8 & 56.9 & 58.3 & 59.3 & 60.9 \\
50.6 & 54.2 & 55.6 & 56.7 & 58.4
\end{tabular}

59.4

62.3

63.2

63.9

64.9 
EARTH TEMPERATURE STATION

TYPE CF SOIL

TYPE CF EARTH SURFAC,E

DATA PROCESSED BY

DATA SOURCE

PERICC OF CESERVATIMN
FT . COLLINS, CDLO.

$S T-8$ UNKNDWN

GRASS

JEA-HU-CHANG

REFERENCE ( 5 )

1958

$19 C 6-1946$

OBSERVED NONTHLY AVERAGE EARTH TEMPERATURES

DEPTH BELOW

SURFACE (IN)

MONTH OF YEAR

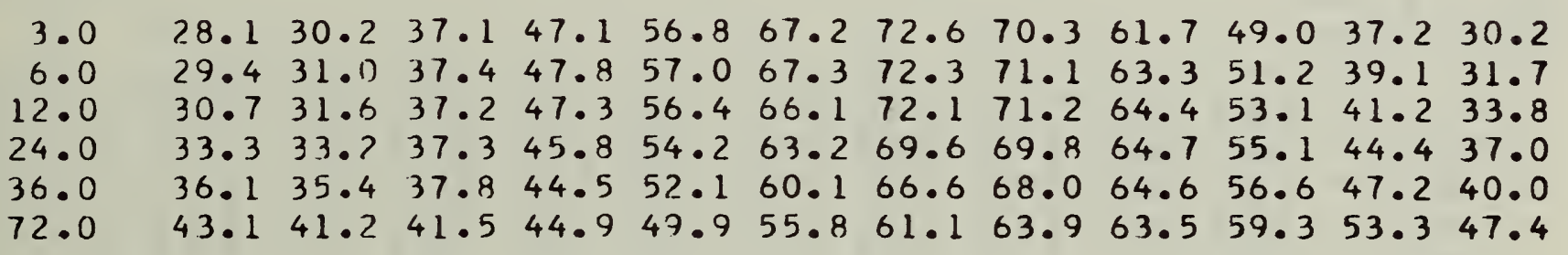

RESULTS OF LEAST SQUARES ANALYSIS

DEPTH BELOW

SURFACE (IN) AVERAGE (A)

$\begin{array}{rl}3.0 & 49.1 \\ 6.0 & 50.0 \\ 12.0 & 50.5 \\ 24.0 & 50.7 \\ 36.0 & 50.8 \\ 72.0 & 52.1\end{array}$

AMPLITUDE (B)

$22 \cdot 2$
$21 \cdot 8$
$21 \cdot 1$
$18 \cdot 9$
$16 \cdot 5$
$11 \cdot 6$

22.2

$21 \cdot 8$

18.9

$16 \cdot 5$

11.6
STANDARO

DEVIATION
C. 58
0.61
0.67
C. 78
0.90
1.19

$1 \cdot 3$

1.1

1. 0

0.9

0.8

0.4

CALCULATEC EARTH TEMPERATURES AT OBSERVED DEPTHS(*)

OEPTH BELOW

SURFACE(IN)

MONTH OF YEAR

$\begin{array}{llllllllllllllll}3.0 & 26.7 & 29.3 & 37.0 & 48.7 & 60.3 & 69.5 & 73.3 & 70.8 & 62.5 & 51.1 & 39.1 & 30.4\end{array}$

$\begin{array}{lllllllllllllll}6.0 & 27.4 & 29.6 & 36.9 & 48.1 & 59.5 & 68.6 & 72.6 & 70.5 & 62.7 & 51.7 & 40.0 & 31.3\end{array}$

$\begin{array}{lllllllllllllll}12.0 & 28.8 & 30.3 & 36.6 & 47.0 & 57.8 & 66.8 & 71.2 & 69.8 & 63.0 & 52.9 & 41.7 & 33.0\end{array}$

$\begin{array}{llllllllllllllll}24.0 & 31.5 & 31.7 & 36.4 & 45.1 & 54.9 & 63.6 & 68.4 & 68.4 & 63.2 & 54.7 & 44.7 & 36.3\end{array}$

$\begin{array}{llllllllllllllll}36.0 & 34.1 & 33.2 & 36.6 & 43.8 & 52.4 & 60.6 & 65.8 & 66.8 & 63.1 & 56.1 & 47.1 & 39.2\end{array}$

$\begin{array}{lllllllllllllll}72.0 & 40.8 & 38.2 & 38.6 & 42.1 & 47.6 & 53.9 & 59.0 & 61.8 & 61.3 & 57.8 & 52.1 & 46.0\end{array}$

\section{(*) BASIC PARAMETERS USED FOR THE CALCULATION}

$A=50.0, B O=24.0, P O=0.54, D=.027$ 
CALCULATEC EARTH TEMPERATURES AT SELECTED CEPTHS

FOR DIFFUSIVITY $=0.025, A=50.0, B O=24.0$ AND $P O=0.54$

DEPTH BELOW

SURFACEI IN

\section{MONTH OF YEAR}

$\begin{array}{rllllllllllll}24.0 & 31.7 & 31.8 & 36.4 & 45.0 & 54.7 & 63.3 & 68.2 & 68.2 & 63.2 & 54.8 & 44.9 & 36.6 \\ 48.0 & 36.9 & 35.1 & 37.2 & 42.8 & 50.1 & 57.7 & 63.0 & 64.9 & 62.6 & 57.1 & 49.5 & 42.2 \\ 72.0 & 41.2 & 38.6 & 38.8 & 42.1 & 47.3 & 53.5 & 58.6 & 61.4 & 61.1 & 57.9 & 52.4 & 46.4 \\ 96.0 & 44.8 & 41.7 & 40.8 & 42.3 & 45.8 & 50.6 & 55.0 & 58.3 & 59.2 & 57.6 & 54.0 & 49.3 \\ 120.0 & 47.4 & 44.4 & 42.9 & 43.2 & 45.3 & 48.7 & 52.4 & 55.6 & 57.1 & 56.8 & 54.6 & 51.2\end{array}$
INTEGRATED AVERAGE FROM

$\begin{array}{llllllllllllll}\text { SURFACE } & 38.3 & 36.8 & 38.6 & 43.6 & 50.1 & 56.8 & 61.5 & 63.2 & 61.2 & 56.3 & 49.5 & 43.1\end{array}$ TO $10 \mathrm{FT}$.

CALCULATED AUGUST EARTH TEMPERATURE AT SELECTED DIFFUSIVITIES AND SELECTEN DEPTHS

DEPTH BELOW

SURFACE (IN)

INTEGRATED

$$
24.0
$$

48.0

72.0

96.0

120.0

AVERAGE FROM

SURFACE

TO $10 \mathrm{FT}$.

\begin{tabular}{lllll}
\multicolumn{5}{c}{ DIFFUSIVITIES } \\
0.010 & 0.020 & 0.025 & 0.030 & 0.040 \\
66.3 & 67.9 & 68.2 & 68.5 & 68.9 \\
60.9 & 64.0 & 64.9 & 65.5 & 66.3 \\
56.2 & 60.3 & 61.4 & 62.3 & 63.6 \\
52.8 & 56.9 & 58.3 & 59.3 & 60.9 \\
50.6 & 54.2 & 55.6 & 56.7 & 58.4 \\
& & & & \\
59.4 & 62.3 & 63.2 & 63.9 & 64.9
\end{tabular}


EARTH TEMPERATURE STATION

TYPE OF SOIL

TYPE CF EARTH SIJRFACE

DATA PROCESSED BY

DATA SOURCE

PERIOC OF OBSERVATINN
FT. COLLINS, CDLO.

LOAM

SPARSE VEGETATION

CL IMATOLOGICAL DATA

$19 t 0-1961$

OBSERVED MONTHLY AVERAGE EARTH TEMPERATURES

MONTH DF YEAR

DEPTH BELOW

SURFACE(IN)

$\begin{array}{lllllllllllllll}3.0 & 27.8 & 31.4 & 38.5 & 51.7 & 61.8 & 71.1 & 78.8 & 77.7 & 66.1 & 53.7 & 38.1 & 31.9\end{array}$ $\begin{array}{lllllllllllllll}6.0 & 28.4 & 31.8 & 38.1 & 53.2 & 61.7 & 70.7 & 78.7 & 77.9 & 66.9 & 54.9 & 40.3 & 33.0\end{array}$ $12.0 \quad 28.8 \quad 31.4 \quad 36.0 \quad 49.6 \quad 58.1 \quad 66.4 \quad 75.0 \quad 74.7 \quad 65.0 \quad 53.940 .6 \quad 33.8$

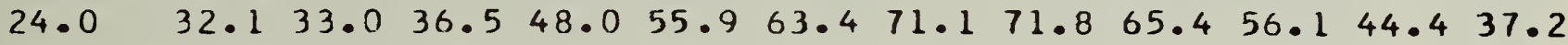
$\begin{array}{llllllllllllll}36.0 & 34.7 & 34.5 & 36.6 & 46.1 & 53.7 & 60.3 & 68.2 & 69.9 & 65.5 & 57.5 & 47.3 & 40.0\end{array}$ $\begin{array}{lllllllllllll}72.0 & 42.3 & 40.2 & 40.2 & 44.2 & 49.2 & 54.6 & 60.6 & 64.1 & 63.9 & 59.3 & 52.9 & 46.7\end{array}$

RESULTS OF LEAST SQUARES ANALYSIS DEPTH BELCW SURFACE(IN) AVERAGE(A)

AMPLITUDE(B) PHASE ANGLE(P)

STANDARD

$\begin{array}{rl}3.0 & 52.5 \\ 6.0 & 53 \cdot 1 \\ 12.0 & 51.2 \\ 24.0 & 51.3 \\ 36.0 & 51.3 \\ 72.0 & 51.6\end{array}$

$25 \cdot 2$
$24 \cdot 7$
$22 \cdot 8$
$19 \cdot 9$
$17 \cdot 8$
$12 \cdot 1$

C. 58

0.60

C. 66

0.77

C. 89

1.21

DEVIATION

CALCULATEC EARTH TEMPERATURES AT OBSERVED CEPTHS(*)

DEPTH BELOW

SURFACE (IN)

MONTH OF YEAR

$\begin{array}{rlllllllllllllll}3.0 & 24.8 & 27.6 & 35.9 & 48.5 & 61.2 & 71.1 & 75.2 & 72.5 & 63.5 & 51.2 & 38.3 & 28.8 \\ 6.0 & 25.6 & 28.0 & 35.7 & 47.8 & 60.2 & 70.1 & 74.4 & 72.1 & 63.7 & 51.9 & 39.3 & 29.8 \\ 12.0 & 27.1 & 28.7 & 35.5 & 46.6 & 58.3 & 68.1 & 72.8 & 71.4 & 64.1 & 53.2 & 41.2 & 31.8 \\ 24.0 & 30.2 & 30.3 & 35.3 & 44.6 & 55.0 & 64.4 & 69.7 & 69.7 & 64.3 & 55.3 & 44.5 & 35.5 \\ 36.0 & 33.1 & 32.1 & 35.6 & 43.1 & 52.3 & 61.1 & 66.7 & 67.9 & 64.2 & 56.7 & 47.2 & 38.8 \\ 72.0 & 40.6 & 37.7 & 37.9 & 41.4 & 47.1 & 53.7 & 59.2 & 62.3 & 62.0 & 58.5 & 52.6 & 46.2\end{array}$

(*) basic parameters uSEd for the calculation

$A:=50 \cdot 0, B D=26 \cdot 0, P C=0.54, D=.025$ 
CALCULATED EARTH TEMPERATURES AT SELECTED CEPTHS

FOR DIFFUSIVITY $=0.025, \quad A=50.0, B D=26.0$ AND $P D=0.54$

DEPTH BELOW

MONTH OF YEAR
SURFACE (IN)
24.030
J F
F $\quad M$
$\begin{array}{lllll}A & S & 0 & N & D\end{array}$
$\begin{array}{lllllllllllllll}48.0 & 35.8 & 33.9 & 36.1 & 42.2 & 50.2 & 58.3 & 64.0 & 66.1 & 63.7 & 57.7 & 49.4 & 41.6\end{array}$

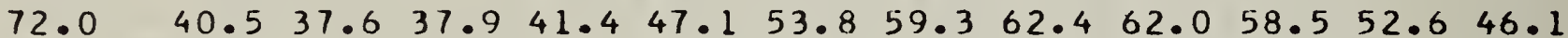

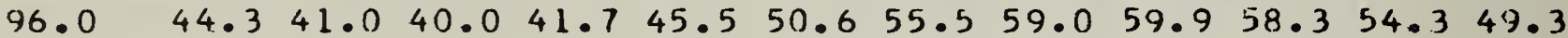

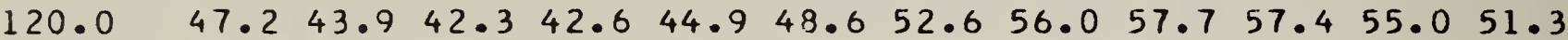
INTEGRATEO
AVERAGE FROM
$\begin{array}{lllllllllllllll}\text { SURACE } & 37.3 & 35.7 & 37.6 & 43.0 & 50.1 & 57.4 & 62.5 & 64.3 & 62.2 & 56.9 & 49.5 & 42.5\end{array}$ TO $10 \mathrm{FT}$.

M J

CALCULATED AUGUST EARTH TEMPERATURE AT SELECTED DIFFUSIVITIES AND SELECTED DEPTHS

DEPTH BELOW

SURFACE (IN)

24.0

48.0

72.0

96.0

120.0

I NTEGRATED

AVERAGE FROM

SURFACE

TO $10 \mathrm{FT}$.

\begin{tabular}{lllll}
\multicolumn{5}{c}{ DIFFUSIVITIES } \\
0.010 & 0.020 & 0.025 & 0.030 & 0.040 \\
67.7 & 69.4 & 69.8 & 70.1 & 70.5 \\
61.8 & 65.2 & 66.1 & 66.8 & 67.7 \\
56.7 & 61.1 & 62.4 & 63.3 & 64.7 \\
53.0 & 57.5 & 59.0 & 60.1 & 61.8 \\
50.7 & 54.6 & 56.0 & 57.2 & 59.1
\end{tabular}

60.2

63.4

$64 \cdot 3$

65.1

66.1 
EARTH TEMPERATURE STATION

TYPE CF SOIL

TYPE CF EARTH SURFACE

DATA PROCESSED QYY.

DATA SOURCE

PERIOD OF OBSERVATIDN
GAINESVILLE, FLA.

SAND

SOC

CLIMATOLOGICAL DATA

$1960-1961$

\section{OBSERVED MOVTHLY AVERAGE EARTH TEMPERATURES}

MONTH OF YEAR

DEPTH BELOW

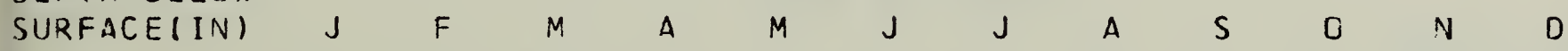

$\begin{array}{lllllllllllllllll}1.0 & 60.4 & 62.9 & 69.5 & 76.2 & 86.2 & 86.1 & 88.1 & 86.6 & 83.7 & 77.7 & 70.9 & 61.1\end{array}$

$\begin{array}{llllllllllllll}4.0 & 59.9 & 61.4 & 67.7 & 74.3 & 80.5 & 83.5 & 86.0 & 85.1 & 82.2 & 76.6 & 69.8 & 59.9\end{array}$

$\begin{array}{llllllllllllll}8.0 & 59.5 & 60.3 & 63.8 & 72.8 & 79.3 & 82.9 & 85.7 & 85.0 & 82.4 & 76.6 & 69.8 & 60.0\end{array}$

RESLLTS OF LEAST SQUARES ANALYSIS

DEPTH BELOW

SURFACE(IN) AVERAGE (A)
75.9

74.0

73.3
AMPL ITUDE (B)

PHASE ANGLE(P)

14.0
13.2
13.7
C. 52

C. 59

0.67
STANDARD DEVIATION

2.9
2.4
2.8 
CALCULATEC EARTH TEMPERATURES AT SELECTED LEPTHS

FOR DIFFUSIVITY $=0.025, \quad A=74.0, B O=10.0$ AND $P O=0.60$

\section{DEPTH BELOW}

SURFACE (IN)

$$
\text { MONTH OF YEAR }
$$

\begin{tabular}{|c|c|c|c|c|c|c|c|c|c|c|c|c|}
\hline $\begin{array}{l}24.0 \\
48.0 \\
72.0 \\
96.0 \\
20.0\end{array}$ & $\begin{array}{l}66.5 \\
68.7 \\
70.6 \\
72.0 \\
73.1\end{array}$ & $\begin{array}{l}66.3 \\
67.8 \\
69.3 \\
70.6 \\
71.8\end{array}$ & $\begin{array}{l}68.0 \\
68.5 \\
69.3 \\
70.2 \\
71.1\end{array}$ & $\begin{array}{l}71.5 \\
70.7 \\
70.5 \\
70.7 \\
71.1\end{array}$ & $\begin{array}{l}75.5 \\
73.7 \\
72.6 \\
72.1 \\
71.9\end{array}$ & $\begin{array}{l}79.2 \\
76.9 \\
75.2 \\
74.0 \\
73.3\end{array}$ & $\begin{array}{l}81.4 \\
79.2 \\
77.4 \\
75.9 \\
74.8\end{array}$ & $\begin{array}{l}81.7 \\
80.2 \\
78.7 \\
77.3 \\
76.2\end{array}$ & $\begin{array}{l}79.8 \\
79.4 \\
78.7 \\
77.8 \\
76.9\end{array}$ & $\begin{array}{l}76.5 \\
77.3 \\
77.5 \\
77.3 \\
76.9\end{array}$ & $\begin{array}{l}72.3 \\
74.2 \\
75.3 \\
75.9 \\
76.0\end{array}$ & $\begin{array}{l}68.7 \\
71.1 \\
72.8 \\
74.0 \\
74.7\end{array}$ \\
\hline
\end{tabular}
INTEGRATED AVERAGE FRUM

CALCULATED AUGUST EARTH TEMPERATURE AT SELECTED DIFFUSIVITIES AND SELECTED DEPTHS

DEPTH BELOW

SURFACE (IN)

$$
\begin{array}{r}
24.0 \\
48.0 \\
72.0 \\
96.0 \\
120.0
\end{array}
$$

INTEGRATED

AVERAGE FROM

SURFACE

TO $10 \mathrm{FT}$.

$\begin{array}{lc} & \text { DIFFUSIVITIES } \\ 0.010 & 0.020 \\ 80.8 & 81.5 \\ 78.5 & 79.8 \\ 76.5 & 78.2 \\ 75.0 & 76.8 \\ 74.2 & 75.6\end{array}$

0.025

0.030

0.040

81.7

81.8

80.5

79.1

77.8

76.7

82.0

80.8

78.7

77.3

76.2

79.6

78.5

77.4

77.9

79.1

79.5

79.8

80.2 
EARTH TEMPERATURE STATION

TYPE CF SDIL

TYPE CF EARTH SURFACE

DATA PROCESSED BY

DATA SOURCE

PERICO OF OBSERVATION
ATHENS, GA.

SANDY LOAM

THIN GRASS

CLIMATOLOGICAL DATA

$19 t 0-1962$

DBSERVED MCNTHLY AVERAGE EARTH TEMPERATURES

MONTH OF YEAR

DEPTH BELOW

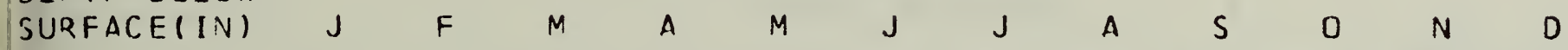

$\begin{array}{lllllllllllllll}2.0 & 44.8 & 51.7 & 52.4 & 60.0 & 76.0 & 80.9 & 83.7 & 82.4 & 78.4 & 70.5 & 58.7 & 45.8\end{array}$

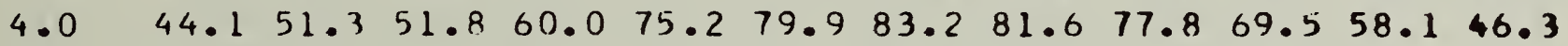

$8.0 \quad 46.252 .8 \quad 54.1 \quad 61.2 \quad 75.5 \quad 80.6 \quad 83.6 \quad 83.5 \quad 80.0 \quad 72.4 \quad 60.3 \quad 49.4$

RESLLTS DF LFAST SQUARES ANALYSIS

DEPTH BELDW

SURFACE (IN) AVERAGF(A)

2.0

4.0

65.4

64.9

66.6
AMPLITUDE (B)

20.1

19.7

19.1
STANDARD

DEVIATION

3. 0

2.9

2. 8 


\section{CALCULATEC EARTH TEMPERATURES AT SELECTED CEPTHS}

FOR DIFFUSIVITY $=0.025, A=67.0, B O=18.0$ AND $P D=0.60$

DEPTH BELOW

MONTH OF YEAR
SURFACE (IN)
24.0
53.553 .1
$F \quad M$
A
M J
$J$
A S
$0 \quad N$
$N \quad D$
$\begin{array}{llllllllll}56.3 & 62.4 & 69.7 & 76.4 & 80.4 & 80.9 & 77.5 & 71.4 & 64.0 & 57.5\end{array}$
$\begin{array}{llllllllllllll}48.0 & 57.5 & 55.9 & 57.1 & 61.0 & 66.4 & 72.2 & 76.4 & 78.1 & 76.8 & 72.9 & 67.3 & 61.7\end{array}$
$\begin{array}{llllllllllllll}72.0 & 60.8 & 58.5 & 58.5 & 60.7 & 64.5 & 69.1 & 73.0 & 75.4 & 75.5 & 73.3 & 69.3 & 64.8\end{array}$

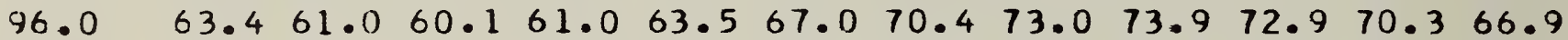
$120.0 \quad 65.4 \quad 63.0 \quad 61.7 \quad 61.8 \quad 63.2 \quad 65.7 \quad 68.5 \quad 71.0 \quad 72.3 \quad 72.2 \quad 70.7 \quad 68.2$
INTEGRATED
AVERAGE FROM $\begin{array}{lllllllllllllll}\text { SURFACE } & 58.5 & 57.1 & 58.2 & 61.7 & 66.5 & 71.6 & 75.3 & 76.9 & 75.7 & 72.3 & 67.2 & 62.3 \\ \text { TO } 10 \mathrm{FT} \text {. } & & & & & & \end{array}$

CALCULATEC AUgUST EARTH TEMPERATURE AT SELECTED DIFFUSIVITIES AND SELECTED DEPTHS

DEPTH BELOW

SURFACE(IN)

24.0
48.0
72.0
96.0
120.0

I NTEGRATED

AVERAGE FROM

SURFACE

TO $10 \mathrm{FT}$.
DIFFUSIVITIES

$\begin{array}{lllll}0.010 & 0.020 & 0.025 & 0.030 & 0.040\end{array}$

79.3

75.0

$71 \cdot 4$

68.9

67.3

80.6

77.5

74.5

72.0

69.9

80.9

78.1

75.4

73.0

71.0

$81 \cdot 1$

78.6

76.1

73.8

71.8

81.4

79.3

77.1

75.0

73.1

$\begin{array}{lllll}74.0 & 76.2 & 76.9 & 77.4 & 78.2\end{array}$ 
EARTH TEMPERATURE STATION

TYPE CF SOIL

TYPE CF EARTH SURFACE

DATA PROCESSED BY

DATA SOURCE

PERICD OF ORSERVATION
TIFTON, GA

$S T-12$
GRASS

JEN-HU-CHANG

REFERENCE (5)

1958

1954-1955

OHSERVED MONTHLY AVERAGE EARTH TEMPERATURES

\section{DEPTH BELOW}

SURFACE (IN)

3. 0

$47.5 \quad 51.5 \quad 65.0$

54.957 .264 .874 .6

MONTH OF YEAR

$M A T H$ OF YEAR

$\begin{array}{lllll}A & S & 0 & N & D\end{array}$

$\begin{array}{lllllllll}8 & 85.5 & 90.2 & 89.5 & 89.8 & 83.0 & 69.8 & 56.2 & 49.5\end{array}$

$\begin{array}{llllllllll}6 & 78.5 & 83.5 & 85.2 & 86.0 & 80.0 & 74.2 & 62.2 & 54.5\end{array}$

RESLLTS OF LEAST SQUARES ANALYSIS DEPTH BELOW SURFACE (IN)

AVERAGE (A)

AMPLITUDE (B)

PHASE ANGLE(P)

STANDARD

DEVIATION

$\begin{array}{ll}3.0 & 71.1 \\ 6.0 & 71.4\end{array}$

22.5

16.0

C. 40

0.50

2.4

2.1 


\section{CALCULATED EARTH TEMPERATURES AT SELECTED CEPTHS}

FOR DIFFUSIVITY $=0.02 \mathrm{~b}, \quad A=71.0, B O=16.0$ AND $P O=0.60$

MONTH OF YEAR

\section{DEPTH BELOW}

SURFACE (IN)

$$
\begin{array}{r}
24.0 \\
48.0 \\
72.0 \\
96.0 \\
120.0
\end{array}
$$

INTEGRATED

$$
\begin{aligned}
& \begin{array}{llllllllllll}
59.0 & 58.7 & 61.4 & 67.0 & 73.4 & 79.3 & 82.9 & 83.3 & 80.3 & 74.9 & 68.3 & 62.6
\end{array} \\
& \begin{array}{llllllllllllll}
62.5 & 61.1 & 62.2 & 65.7 & 70.5 & 75.6 & 79.3 & 80.9 & 79.7 & 76.2 & 71.2 & 66.3
\end{array} \\
& \begin{array}{llllllllllll}
65.5 & 63.5 & 63.4 & 65.4 & 68.8 & 72.9 & 76.4 & 78.5 & 78.5 & 76.6 & 73.0 & 69.1
\end{array}
\end{aligned}
$$

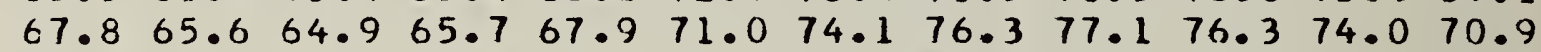

$$
\begin{aligned}
& \begin{array}{lllllllllllllll}
69.5 & 67.5 & 66.3 & 66.4 & 67.6 & 69.9 & 72.3 & 74.5 & 75.7 & 75.6 & 74.3 & 72.1
\end{array}
\end{aligned}
$$

AVERAGE FROM

SURFACE

$\begin{array}{llllllllllll}63.5 & 62.2 & 63.1 & 66.3 & 70.6 & 75.1 & 78.4 & 79.8 & 78.8 & 75.7 & 71.2 & 66.8\end{array}$ TO $10 \mathrm{FT}$.

CALCULATED AUGUST EARTH TEMPERATURE AT SELECTED DIFFUSIVITIES AND SELECTED DEPTHS

DEPTH BELOW

SURFACE (IN)

$$
\begin{array}{r}
24.0 \\
48.0 \\
72.0 \\
96.0 \\
120.0
\end{array}
$$

INTEGRATED AVERAGE FROM SURFACE TO $10 \mathrm{FT}$.

\begin{tabular}{lcccc}
\multicolumn{5}{c}{ DIFFUSIVITIES } \\
0.010 & 0.020 & 0.025 & 0.030 & 0.040 \\
81.9 & 83.1 & 83.3 & 83.5 & 83.8 \\
78.1 & 80.3 & 80.9 & 81.3 & 81.9 \\
74.9 & 77.7 & 78.5 & 79.1 & 80.0 \\
72.7 & 75.4 & 76.3 & 77.1 & 78.1 \\
71.3 & 73.6 & 74.5 & 75.3 & 76.4
\end{tabular}

77.2

79.2

79.8

$\varepsilon 0.3$

81.0 
EARTH TEMPERATURE STATION

TYPE OF SOIL

TYPE CF EARTH SURFACE

DATA PROCESSEO BY.

DATA SOURCE

PERIOC OF MESERVATION
MOSCOW, IDAHO

UNKNOWN

UNKNOWN

E. M.FITTON

REFERENCE (4)

$18 c 8-1901$

OBSERVEU MOVTHLY AVERAGE EARTH TEMPERATURES

DEPTH BELOW

SURFACE (IN)

MONTH OF YEAR

$\begin{array}{rllllllllllll}3.0 & 30.8 & 28.9 & 34.4 & 41.2 & 51.2 & 58.0 & 64.1 & 67.5 & 54.6 & 47.8 & 40.8 & 33.8 \\ 6.0 & 31.8 & 30.2 & 34.6 & 42.7 & 48.6 & 56.0 & 63.6 & 65.4 & 56.8 & 50.5 & 41.6 & 34.6 \\ 9.0 & 32.8 & 31.0 & 35.0 & 45.9 & 48.9 & 54.8 & 62.9 & 64.9 & 57.5 & 51.8 & 42.8 & 36.4 \\ 12.0 & 38.2 & 32.8 & 35.4 & 44.7 & 48.4 & 54.8 & 62.2 & 64.3 & 58.1 & 52.2 & 43.6 & 37.4 \\ 24.0 & 35.8 & 34.5 & 36.2 & 44.5 & 47.5 & 52.9 & 59.2 & 62.5 & 58.2 & 53.2 & 45.8 & 39.2 \\ 36.0 & 37.8 & 36.2 & 37.0 & 40.5 & 46.2 & 50.1 & 55.9 & 60.0 & 57.8 & 53.8 & 48.0 & 41.6 \\ 48.0 & 39.8 & 38.0 & 38.0 & 40.5 & 45.4 & 48.8 & 53.7 & 58.1 & 57.1 & 53.8 & 48.8 & 43.4 \\ 60.0 & 40.8 & 39.5 & 38.8 & 40.6 & 44.6 & 47.5 & 51.8 & 56.3 & 56.5 & 54.0 & 49.6 & 44.6 \\ 72.0 & 42.8 & 40.8 & 39.6 & 41.5 & 44.6 & 47.1 & 50.6 & 54.7 & 55.5 & 54.0 & 51.6 & 46.2\end{array}$

RESLLTS OF LEAST SQUARES ANALYSIS

DEPTH BELCW

SURFACE (IN)

AVERAGE (A)
46.2
46.5
$47 \cdot 1$
47.8
47.5
47.1
47.2
$47 \cdot 1$
47.5

AMPLITUDE (B)

PHASE ANGLE(P)

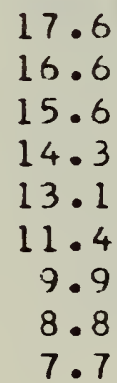

STANDARD DEVIATION
2.2
1.6
1.9
2.1
1.4
0.9
0.8
0.8
0.7

C.ALCULATEC eARTH temperatures at OBSERVED CEPTHS(*)

DEPTH BELOW

SURFACE (IN)

MONTH OF YEAR

$\begin{array}{rllllllllllll}3.0 & 30.1 & 30.3 & 34.7 & 42.7 & 51.5 & 59.5 & 63.8 & 63.7 & 59.0 & 51.2 & 42.0 & 34.4 \\ 6.0 & 30.8 & 30.7 & 34.7 & 42.3 & 50.8 & 58.6 & 63.1 & 63.3 & 59.0 & 51.6 & 42.7 & 35.3 \\ 9.0 & 31.5 & 31.1 & 34.8 & 41.9 & 50.2 & 57.8 & 62.4 & 62.9 & 59.0 & 52.0 & 43.4 & 36.1 \\ 12.0 & 32.2 & 31.6 & 34.8 & 41.6 & 49.5 & 57.1 & 61.7 & 62.5 & 58.9 & 52.3 & 44.1 & 36.8 \\ 24.0 & 34.8 & 33.3 & 35.3 & 40.5 & 47.4 & 54.3 & 59.1 & 60.7 & 58.5 & 53.4 & 46.3 & 39.6 \\ 36.0 & 37.2 & 35.1 & 36.0 & 40.0 & 45.7 & 51.9 & 56.7 & 58.9 & 57.8 & 53.9 & 48.0 & 42.0 \\ 48.0 & 39.3 & 36.8 & 37.0 & 39.8 & 44.5 & 50.0 & 54.5 & 57.1 & 57.0 & 54.1 & 49.3 & 44.0 \\ 60.0 & 41.2 & 38.5 & 38.0 & 39.9 & 43.6 & 48.4 & 52.6 & 55.5 & 56.0 & 54.1 & 50.2 & 45.6 \\ 72.0 & 42.8 & 40.0 & 39.1 & 40.2 & 43.1 & 47.1 & 51.0 & 53.9 & 54.9 & 53.8 & 50.8 & 46.8\end{array}$

\section{(*) basic parameters used for the calculation}

$A=47.0, B O=18.0, P C=0.73, D=.019$ 
CALCULATEC EARTH TEMPERATURES AT SELECTED LEPTHS

FOR DIFFUSIVITY $=0.025, A=47.0, B O=18.0$ AND $P O=0.73$

DEPTH BELOW

SURFACEIIN)

MONTH OF YEAR

$F \quad M \quad A \quad M \quad J \quad J \quad A \quad S \quad J \quad N \quad D$

$24.0 \quad 34.2 \quad 32.9 \quad 35.1 \quad 40.7 \quad 47.8 \quad 54.9 \quad 59.7 \quad 61.1 \quad 58.6 \quad 53.1 \quad 45.8 \quad 39.0$

$\begin{array}{llllllllllllll}48.0 & 38.3 & 36.0 & 36.5 & 39.8 & 45.0 & 50.9 & 55.5 & 58.0 & 57.4 & 54.1 & 48.7 & 43.1\end{array}$

$\begin{array}{lllllllllllll}72.0 & 41.6 & 38.9 & 38.3 & 39.9 & 43.4 & 48.0 & 52.2 & 55.1 & 55.7 & 54.0 & 50.4 & 45.9\end{array}$

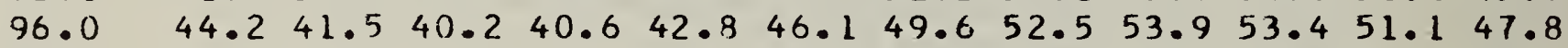

$\begin{array}{lllllllllllll}120.0 & 46.0 & 43.5 & 42.0 & 41.6 & 42.7 & 45.1 & 47.8 & 50.4 & 52.1 & 52.4 & 51.2 & 48.9\end{array}$ INTEGRATED

AVERAGE FROM

SURFACE

TO $10 \mathrm{FT}$.

$\begin{array}{lllllllllllll}39.3 & 37.2 & 37.6 & 40.6 & 45.2 & 50.4 & 54.6 & 56.8 & 56.3 & 53.3 & 48.5 & 43.5\end{array}$

CALCULATED AUGUST EARTH TEMPERATURE AT SELECTED DIFFUSIVITIES AND SELECTED DEPTHS

\begin{tabular}{rlllll} 
DEPTH BELOW & \multicolumn{5}{c}{ DIFFUSIVITIES } \\
SURFACEIIN) & 0.010 & 0.020 & 0.025 & 0.030 & 0.040 \\
24.0 & 59.3 & 60.8 & 61.1 & 61.4 & 61.8 \\
48.0 & 54.0 & 57.3 & 58.0 & 58.5 & 59.3 \\
72.0 & 50.9 & 54.1 & 55.1 & 55.8 & 56.9 \\
96.0 & 48.4 & 51.5 & 52.5 & 53.3 & 54.6 \\
120.0 & 47.0 & 49.4 & 50.4 & 51.3 & 52.6 \\
INTEGRATED & & & & & \\
AVERAGE FROM & 53.7 & 56.1 & 56.8 & 57.3 & 58.2 \\
SURFACE & & & & & \\
TO 1OFT. & & & &
\end{tabular}


EARTH TEMPERATURE STATION

TYPE CF SOIL

TYPE CF EARTH SURFACE

DATA PROCFSSED BY

DATA SOURCE

PERIOD OF OESERVATION
ARGONNE, ILLINOIS

$S T-14$

SANDY CLAY

PASTURE GRASS

J.E.CARSON

RE FERENCE (10)

1963

$19 £ 3-1955$

UBSERVED MONTHLY AVERAGE EARTH TEMPERATURES

DEPTH BELOW

SURFACE (IN)

$\begin{array}{lllllllllllll}0 . & 24.0 & 29.3 & 33.6 & 49.4 & 57.4 & 68.9 & 73.6 & 71.3 & 64.1 & 53.2 & 37.6 & 26.4 \\ 0.4 & 31.7 & 32.5 & 37.6 & 50.1 & 60.7 & 72.0 & 78.0 & 76.0 & 67.2 & 56.5 & 42.6 & 33.7 \\ 3.9 & 31.8 & 32.1 & 36.5 & 48.9 & 59.7 & 71.3 & 77.1 & 75.2 & 66.6 & 56.4 & 42.5 & 33.6 \\ 7.9 & 32.9 & 32.5 & 36.4 & 47.8 & 58.1 & 69.2 & 75.2 & 74.1 & 66.8 & 57.3 & 44.2 & 35.0 \\ 19.7 & 35.8 & 34.5 & 37.0 & 45.7 & 55.0 & 64.8 & 70.9 & 71.6 & 66.7 & 59.1 & 47.9 & 38.9 \\ 39.4 & 40.0 & 37.9 & 38.6 & 43.9 & 51.6 & 59.5 & 65.9 & 68.1 & 66.0 & 60.6 & 52.2 & 44.5 \\ 20.0 & 50.3 & 47.7 & 45.8 & 45.3 & 47.0 & 50.1 & 53.9 & 57.3 & 59.2 & 59.2 & 57.3 & 54.1 \\ 48.0 & 52.3 & 52.4 & 52.5 & 51.9 & 51.5 & 51.2 & 50.6 & 50.7 & 51.0 & 51.3 & 51.6 & 52.2\end{array}$

DEPTH BELOW

RESULTS OF LEAST SQUARES ANALYSIS

SURFACE (IN)

AVERAGE (A)

AMPLITUDE (B)

PHASE ANGLE(P)

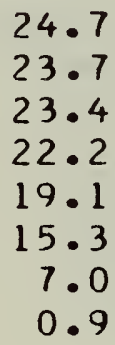

C. 60

C. 65

0.66

C. 72

52.6

52.4

52.5

52.3

120.0

348.0
0.86

1.07

1.85

4. 08
STANDARD

DEVIATION

3.2

1.9

2.1

1.8

1.4

1.0

0.5

0.3

CALCULATEC FARTH TEMPERATURES AT OBSERVED DEPTHS(*)

DEPTH BELOW

SURFACE (IN)

MONTH OF YEAR

$\begin{array}{lllllllllllllllll}0 . & 28.3 & 29.4 & 35.8 & 46.7 & 58.4 & 68.5 & 73.6 & 72.7 & 65.7 & 55.1 & 43.0 & 33.4\end{array}$

$\begin{array}{lllllllllllll}0.4 & 28.4 & 29.4 & 35.8 & 46.6 & 58.3 & 68.3 & 73.5 & 72.6 & 65.8 & 55.2 & 43.1 & 33.5\end{array}$

$\begin{array}{llllllllllllll}3.9 & 29.3 & 29.9 & 35.8 & 46.0 & 57.3 & 67.2 & 72.5 & 72.1 & 65.8 & 55.8 & 44.1 & 34.6\end{array}$

$\begin{array}{llllllllllllll}7.9 & 30.3 & 30.5 & 35.7 & 45.4 & 56.3 & 66.1 & 71.5 & 71.6 & 65.9 & 56.4 & 45.2 & 35.8\end{array}$

$\begin{array}{llllllllllllll}19.7 & 33.2 & 32.3 & 36.0 & 44.0 & 53.6 & 62.8 & 68.6 & 69.8 & 65.7 & 57.9 & 47.9 & 39.1\end{array}$

$\begin{array}{lllllllllllllll}39.4 & 37.7 & 35.3 & 37.0 & 42.5 & 50.1 & 58.2 & 64.1 & 66.6 & 64.8 & 59.4 & 51.5 & 43.7\end{array}$

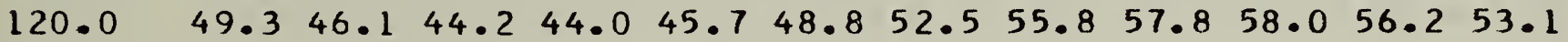

$348.0 \quad 51.7 \quad 51.9 \quad 51.6 \quad 51.3 \quad 50.950 .6 \quad 50.3 \quad 50.250 .450 .751 .151 .4$

\section{(*) BASIC PARAMETERS USED FOR THE CALCULATION}

$A=51.0, B O=23.0, P C=0.70, D=.026$ 
CALCULATED EARTH TEMPERATURES AT SELECTED CEPTHS FOR DIFFUSIVITY $=0.025, A=51.0, B O=23.0$ AND $P O=0.70$

DEPTH BELOW

SURFACE (IN)

MONTH OF YEAR

$\begin{array}{rrrrrrrrrrrrr}\text { SURFACE(IN) } & J & F & M & A & M & J & J & A & S & 0 & N & D \\ 24.0 & 34.4 & 33.0 & 36.2 & 43.5 & 52.6 & 61.6 & 67.4 & 69.0 & 65.6 & 58.4 & 48.9 & 40.3 \\ 48.0 & 39.6 & 36.9 & 37.7 & 42.2 & 48.9 & 56.3 & 62.2 & 65.1 & 64.1 & 59.7 & 52.8 & 45.6 \\ 72.0 & 43.9 & 40.5 & 39.9 & 42.2 & 46.7 & 52.6 & 57.9 & 61.4 & 62.1 & 59.8 & 55.0 & 49.3 \\ 96.0 & 47.2 & 43.8 & 42.2 & 43.0 & 45.8 & 50.2 & 54.6 & 58.2 & 59.8 & 59.0 & 56.0 & 51.8 \\ 120.0 & 49.6 & 46.4 & 44.5 & 44.2 & 45.7 & 48.7 & 52.2 & 55.5 & 57.6 & 57.8 & 56.2 & 53.2\end{array}$
INTEGRATED

AVERAGE FROM

$\begin{array}{llllllllllllll}\text { SURFACE } & 40.9 & 38.4 & 39.2 & 43.2 & 49.1 & 55.7 & 60.9 & 63.6 & 62.7 & 58.8 & 52.6 & 46.2\end{array}$ TO 10 FT.

CALCULATED AUGUST EARTH TEMPERATURE AT SELECTED DIFFUSIVITIES AND SELECTED DEPTHS

DEPTH BELOW

SURFACE (IN)

24.0

48.0

72.0

96.0

120.0

INTEGRATED

AVERAGE FROM

SURFACE

TO $10 \mathrm{FT}$.

$\begin{array}{cc}\text { DIFFUSIVITIES } \\ 0.010 & 0.020\end{array}$

66.7

60.9

56.2

53.0

51.1

68.5

64.2

60.2

56.9

54.3

0.025

0.030

0.040

69.0

65.1

61.4

58.2

55.5

69.3

65.8

62.3

59.3

56.6

69.8

66.7

63.7

60.9

58.3

59.7

62.6

63.6

$64 \cdot 3$

$65 \cdot 3$ 
EARTH TEMPERATURE STATION

TYPE OF SOIL

TYPE CF EARTH SURFACE

DATA PROCESSED BY

DATA SOURCE

PERICO OF OESERVATION
LEMONT, ILLINOIS

$S T-15$

GRASS

JEA-HU-CHANG

REFERENCE (5)

1958

$1952-1954$

\section{OBSERVED MONTHLY AVERAGE EARTH TEMPERATURES}

DEPTH BELOW

SURFACE(IN)

MONTH OF YEAR

$\begin{array}{rllllllllllll}0.4 & 31.2 & 32.8 & 37.8 & 48.9 & 59.9 & 73.4 & 76.2 & 75.1 & 66.5 & 57.4 & 42.4 & 33.8 \\ 3.9 & 31.3 & 32.4 & 36.8 & 47.5 & 58.7 & 72.9 & 75.8 & 74.7 & 65.9 & 57.5 & 43.3 & 34.0 \\ 7.9 & 32.4 & 32.8 & 36.8 & 46.4 & 57.1 & 70.4 & 74.2 & 73.4 & 66.1 & 58.2 & 45.0 & 35.6 \\ 19.7 & 35.2 & 34.8 & 37.2 & 44.8 & 54.0 & 65.6 & 70.6 & 71.0 & 66.3 & 59.6 & 48.6 & 39.4 \\ 39.4 & 39.8 & 37.8 & 38.7 & 43.4 & 50.6 & 59.8 & 65.7 & 67.6 & 65.8 & 60.6 & 52.0 & 44.4 \\ 20.0 & 50.2 & 47.4 & 45.8 & 45.2 & 46.6 & 49.7 & 53.5 & 56.8 & 58.7 & 58.6 & 56.0 & 53.6 \\ 48.0 & 52.2 & 52.2 & 52.1 & 51.8 & 51.3 & 51.0 & 50.1 & 50.2 & 50.5 & 50.8 & 51.4 & 51.9\end{array}$

DEPTH BELOW

SURFACE (IN)

RESLLTS OF LEAST SQUARES ANALYSIS

$\begin{array}{rl}0.4 & 53.1 \\ 3.9 & 52.7 \\ 7.9 & 52.5 \\ 19.7 & 52.4 \\ 39.4 & 52.2 \\ 120.0 & 51.9 \\ 348.0 & 51.3\end{array}$

AVERAGE (A)

\begin{abstract}
AMPLITUDE (B)
\end{abstract}
PHASE ANGLE(P)
STANDARD DEVIATION
$1 \cdot 4$
$1 \cdot 5$
1.3
0.9
0.6
0.4
0.1

\section{CALCULATEC EARTH TEMPERATURES AT OBSERVED DEPTHS(*)}

DEPTH BELOW

SURFACE (IN)

\section{MONTH OF YEAR}

$\begin{array}{rllllllllllll}0.4 & 29.2 & 30.9 & 37.7 & 48.8 & 60.4 & 70.1 & 74.7 & 73.2 & 65.9 & 55.0 & 43.1 & 33.8 \\ 3.9 & 30.1 & 31.3 & 37.6 & 48.2 & 59.5 & 69.1 & 73.8 & 72.8 & 66.0 & 55.6 & 44.0 & 34.8 \\ 7.9 & 31.0 & 31.7 & 37.5 & 47.5 & 58.5 & 67.9 & 72.9 & 72.3 & 66.1 & 56.3 & 45.0 & 35.9 \\ 19.7 & 33.6 & 33.2 & 37.5 & 46.0 & 55.8 & 64.9 & 70.2 & 70.8 & 66.1 & 57.8 & 47.7 & 39.0 \\ 39.4 & 37.7 & 36.0 & 38.2 & 44.3 & 52.3 & 60.4 & 66.1 & 68.1 & 65.6 & 59.5 & 51.3 & 43.4 \\ 20.0 & 49.3 & 46.1 & 44.4 & 44.7 & 46.9 & 50.6 & 54.5 & 57.9 & 59.6 & 59.2 & 56.9 & 53.3 \\ 38.0 & 53.0 & 52.9 & 52.6 & 52.2 & 51.7 & 51.3 & 51.1 & 51.1 & 51.4 & 51.8 & 52.4 & 52.7\end{array}$

(*) BASIC PARAMETERS USED for the CALCULATION

$A=52.0, B O=23.0, P O=0.65, D=.030$ 
CALCULATED FARTH TEMPERATURES AT SELECTED CEPTHS FOR DIFFUSIVITY $=0.025, A=52.0, B D=23.0$ AND $P O=0.66$

DEPTH BELOW

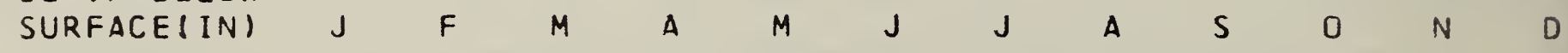

MONTH OF YEAR

$24.0 \quad 35.1 \quad 34.1 \quad 37.6 \quad 45.2 \quad 54.3 \quad 63.1 \quad 68.7 \quad 69.966 .1 \quad 58.7 \quad 49.2 \quad 40.7$

$\begin{array}{llllllllllllll}48.0 & 40.3 & 37.8 & 38.9 & 43.6 & 50.4 & 57.8 & 63.5 & 66.2 & 64.9 & 60.3 & 53.2 & 46.0\end{array}$

$\begin{array}{llllllllllllll}72.0 & 44.6 & 41.4 & 41.0 & 43.5 & 48.2 & 54.0 & 59.2 & 62.6 & 63.0 & 60.5 & 55.6 & 49.9\end{array}$

$96.0 \quad 47.9 \quad 44.6 \quad 43.2 \quad 44.1 \quad 47.1 \quad 51.5 \quad 55.9 \quad 59.4 \quad 60.8 \quad 59.9 \quad 56.7 \quad 52.4$

$\begin{array}{lllllllllllllll}120.0 & 50.3 & 47.2 & 45.4 & 45.2 & 46.9 & 50.0 & 53.5 & 56.8 & 58.7 & 58.8 & 57.0 & 54.0\end{array}$ INTEGRATED

AVERAGE FROM

SURFACE

$41.6 \quad 39.4 \quad 40.4 \quad 44.6 \quad 50.6 \quad 57.2 \quad 62.2 \quad 64.6 \quad 63.5 \quad 59.4 \quad 53.146 .7$ TO $10 \mathrm{FT}$.

CALCULATEC AUGUST EARTH TEMPERATURE AT SELECTED DIFFUSIVITIES AND SELECTED DEPTHS

DEPTH BELDW

SURFACE (IN)

24.0

48.0

72.0

96.0

120.0

INTEGRATED

AVERAGE FROM

SURFACE

TO $10 \mathrm{FT}$.

\begin{tabular}{lllll}
\multicolumn{5}{c}{ DIFFUSIVITIES } \\
0.010 & 0.020 & 0.025 & 0.030 & 0.040 \\
& & & & \\
67.7 & 69.5 & 69.9 & 70.2 & 70.7 \\
62.0 & 65.3 & 66.2 & 66.8 & 67.7 \\
57.4 & 61.4 & 62.6 & 63.5 & 64.8 \\
54.1 & 58.1 & 59.4 & 60.4 & 62.0 \\
52.2 & 55.5 & 56.8 & 57.8 & 59.5
\end{tabular}

60.8

63.7

$64 \cdot 6$

65.3

66.3 
EARTH TEMPERATURE STATION

TYPE CF SOIL

TYPE CF EARTH SURFACE

DATA PROCESSED' BY

DATA SOURCE

PERIOD OF OESERVATION
URBANA, ILLINOIS

SI LT LOAM

BLUEGRASS SOD

CLIMATOLOGICAL DATA

$1960-1962$

OBSERVED MONTHLY AVERAGE EARTH TEMPERATURES

MONTH OF YEAR

DEPTH BELOW

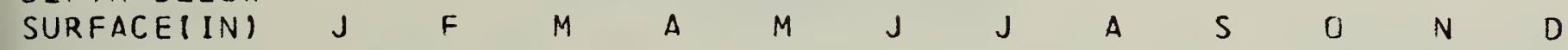

$\begin{array}{llllllllllllllll}4.0 & 33.7 & 33.4 & 38.4 & 50.7 & 63.0 & 73.1 & 77.0 & 76.8 & 71.4 & 62.7 & 46.8 & 35.6\end{array}$

$\begin{array}{lllllllllllll}8.0 & 34.4 & 34.2 & 38.3 & 49.8 & 61.6 & 71.6 & 75.9 & 73.4 & 71.5 & 60.0 & 48.1 & 37.4\end{array}$

DEPTH BELOW

RESLLTS OF L.EAST SQUARES ANALYSIS
AMPLITUDE (B) PHASE ANGLE(P)

23.5

22.0
STANDARD

DEVIATION

2.9

2.5 


\section{CALCULATEC EARTH TEMPERATURES AT SELECTED DEPTHS \\ FOR DIFFUSIVITY $=0.025, \quad A=53.0, B D=25.0$ AND $P O=0.62$}

\section{DEPTH BELOW}

SURFACE ( IN)

MONTH DF YEAR

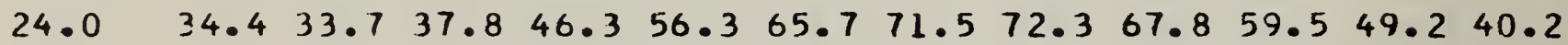

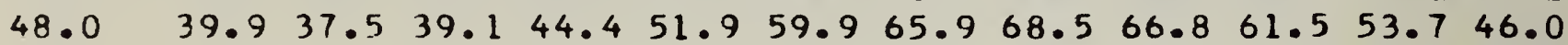

$$
\begin{aligned}
& \begin{array}{lllllllllllll}
72.0 & 44.6 & 41.3 & 41.1 & 44.0 & 49.3 & 55.7 & 61.2 & 64.7 & 64.8 & 61.9 & 56.4 & 50.2
\end{array} \\
& 96.0 \quad 48.2 \quad 44.7 \quad 43.4 \quad 44.6 \quad 48.0 \quad 52.8 \quad 57.6 \quad 61.262 .6 \quad 61.4 \quad 57.8 \quad 53.1
\end{aligned}
$$
INTEGRATED AVERAGE FROM

$\begin{array}{llllllllllllll}\text { SURFACE } & 41.4 & 39.2 & 40.6 & 45.4 & 52.0 & 59.1 & 64.4 & 66.8 & 65.2 & 60.5 & 53.6 & 46.7\end{array}$ TO $10 \mathrm{FT}$.

\section{CALCULATEC AUGUST EARTH TEMPERATURE AT SELECTED DIFFUSIVITIES AND SELECTED DEPTHS}

DEPTH BELOW

SURFACE ( IN)

INTEGRATED

$$
24.0
$$

48.0

72.0

96.0

120.0

AVERAGE FROM

SURFACE

TO $10 \mathrm{FT}$.

\begin{tabular}{lclll}
\multicolumn{5}{c}{ DIFFUSIVITIES } \\
0.010 & 0.020 & 0.025 & 0.030 & 0.040 \\
70.1 & 71.9 & 72.3 & 72.7 & 73.1 \\
64.1 & 67.5 & 68.5 & 69.1 & 70.1 \\
59.1 & 63.4 & 64.7 & 65.6 & 67.0 \\
55.5 & 59.8 & 61.2 & 62.4 & 64.1 \\
53.4 & 57.0 & 58.4 & 59.6 & 61.4 \\
& & & & \\
62.6 & 65.8 & 66.8 & 67.5 & 68.6
\end{tabular}


EARTH TEMPERATURE STATION

TYPE CF SOIL

TYPE OF EARTH SURFACE

DATA PROCESSED BY

DATA SOURCE

PERIOD OF OESERVATION
UR EANA, I LL INO IS

UNKNOWN

UN KNOWN

E.M.FITTON

RE FERENCE (4)

$1913-1915$

OBSERVED MONTHLY AVERAGE EARTH TEMPERATURES

MONTH OF YEAR

DEPTH BELDW

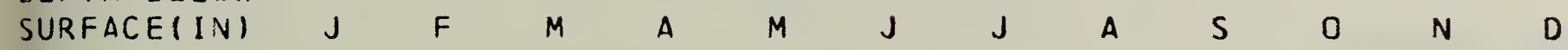

$\begin{array}{llllllllllllll}1.0 & 29.2 & 29.5 & 39.8 & 51.0 & 63.0 & 72.6 & 78.2 & 76.2 & 69.0 & 55.5 & 42.2 & 32.1\end{array}$

$\begin{array}{lllllllllllll}3.0 & 31.0 & 30.6 & 39.5 & 50.6 & 62.2 & 72.2 & 77.8 & 75.8 & 69.0 & 56.8 & 43.0 & 33.4\end{array}$

$\begin{array}{llllllllllllll}6.0 & 32.6 & 31.5 & 39.3 & 49.2 & 60.5 & 70.5 & 75.8 & 74.8 & 68.8 & 57.0 & 44.0 & 35.0\end{array}$

$\begin{array}{llllllllllllll}9.0 & 33.2 & 33.0 & 39.2 & 48.7 & 59.8 & 69.4 & 74.7 & 74.0 & 68.6 & 57.4 & 45.2 & 36.0\end{array}$

$\begin{array}{lllllllllllll}12.0 & 34.0 & 33.2 & 38.6 & 48.4 & 58.8 & 68.0 & 73.8 & 73.2 & 68.2 & 58.0 & 46.2 & 37.4\end{array}$

$\begin{array}{lllllllllllllll}24.0 & 37.6 & 37.1 & 38.6 & 47.1 & 55.4 & 62.6 & 68.5 & 69.7 & 66.7 & 59.5 & 50.6 & 42.7\end{array}$

$\begin{array}{llllllllllllllll}36.0 & 41.0 & 38.8 & 40.1 & 46.0 & 53.6 & 60.3 & 66.0 & 67.8 & 66.1 & 60.7 & 53.0 & 45.8\end{array}$

DEPTH BELOW

RESLLTS OF LEAST SQUARES ANALYSIS SURFACEIIN:

AVERAGE (A)

AMPLITUDE (B)

PHASE ANGLE(P)

STANDARD

DEVIATION

$\begin{array}{ll}1.0 & 53.3 \\ 3.0 & 53.6 \\ 6.0 & 53.4 \\ 9.0 & 53.4 \\ 12.0 & 53.2 \\ 24.0 & 53.1 \\ 36.0 & 53.3\end{array}$

$25 \cdot 0$
$24 \cdot 2$
22.7
21.7
20.9
16.8
14.6

0.62

0.64

0.69

C. 71

0.75

C. 91

1.04
0.9

0.9

0.9

0.7

0.6

0.5

0.3 
CALCULATEC EARTH TEMPERATURES AT SELECTED DEPTHS

FOR DIFFUSIVITY $=0.025, A=55.0, B O=24.0$ AND $P D=0.60$

\section{DEPTH BELOW}

SURFACE (IN)

$$
\text { MONTH OF YEAR }
$$

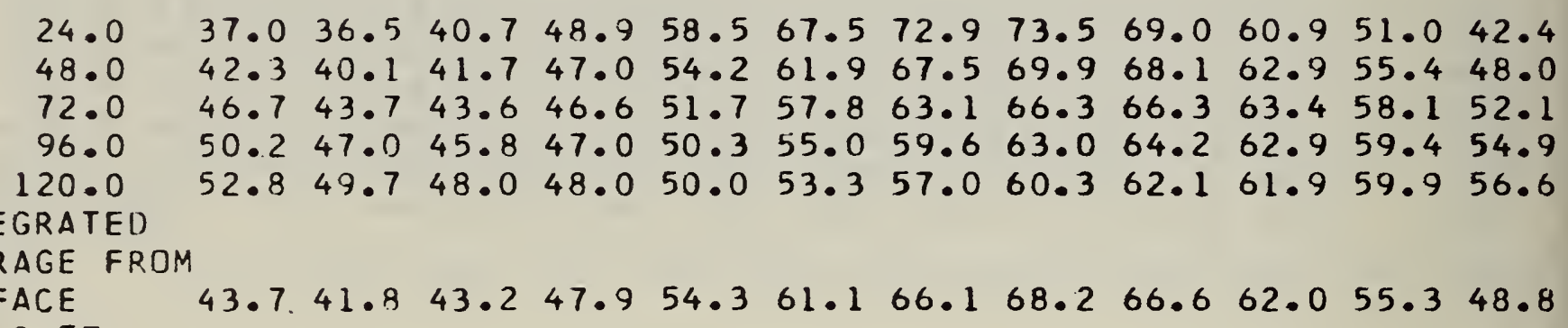

DEPTH BELOW

SURFACE (IN)

$$
24.0
$$

48.0

72.0

96.0

120.0

I NTEGRATED

AVERAGE FROM

SURFACE

TO $10 \mathrm{FT}$.

\section{DIFFUSIVITIES}

$\begin{array}{lllll}0.010 & 0.020 & 0.025 & 0.030 & 0.040 \\ 71.4 & 73.1 & 73.5 & 73.8 & 74.2 \\ 65.7 & 69.0 & 69.9 & 70.5 & 71.4 \\ 60.9 & 65.1 & 66.3 & 67.2 & 68.5 \\ 57.5 & 61.6 & 63.0 & 64.1 & 65.7 \\ 55.4 & 58.9 & 60.3 & 61.4 & 63.1 \\ & & & & \\ 64.3 & 67.3 & 68.2 & 68.9 & 70.0\end{array}$


EARTH TEMPERATURE STATION

TYPE CF SOIL

TYPE CF EARTH SURFACE

DATA PROCESSED BY

OATA SOURCE

PERIOC OF OBSERVATION
WEST LAFAYETTE, INDT- 18

SI LT LOAM

FE SQUE GRASS

CLIMATOLOGICAL DATA

1962

UBSERVED MONTHLY AVERAGE EARTH TEMPERATURES

DEPTH BELOW

SURFACEI IN

MONTH OF YEAR

$$
\begin{aligned}
& \text { 2. } 0 \\
& \text { 4. } 0 \\
& 8.0 \\
& 29.329 .5 \\
& 48.066 .774 .5 \\
& \begin{array}{lllllll}
74.3 & 75.6 & 66.2 & 57.0 & 42.1 & 30.8
\end{array} \\
& \begin{array}{lllllll}
75.7 & 66.5 & 57.7 & 43.0 & 32.1
\end{array} \\
& \begin{array}{lllllllll}
47.4 & 63.5 & 71.4 & 72.5 & 73.7 & 66.7 & 58.8 & 45.6 & 35.9
\end{array}
\end{aligned}
$$

RFSLLTS OF LEAST SQUARES ANALYSIS

DEPTH BELOW SURFACE (IV) AVERAGE (A)
2.0
4.0
8.0

AMPLITUDE (B)

25.2
25.4
21.9
PHASE ANGLE(P)

$C .60$
0.67
$C .69$
STANDARD DEVIATION

2.6

1.9

2.0 
CALCULATEC FARTH TEMPERATURES AT SELECTED DEPTHS

FOR DIFFUSIVITY $=0.025, \quad A=52.0, B O=26 . C$ AND $P O=0.60$

\section{DEPTH BELOW}

MONTH OF YEAR

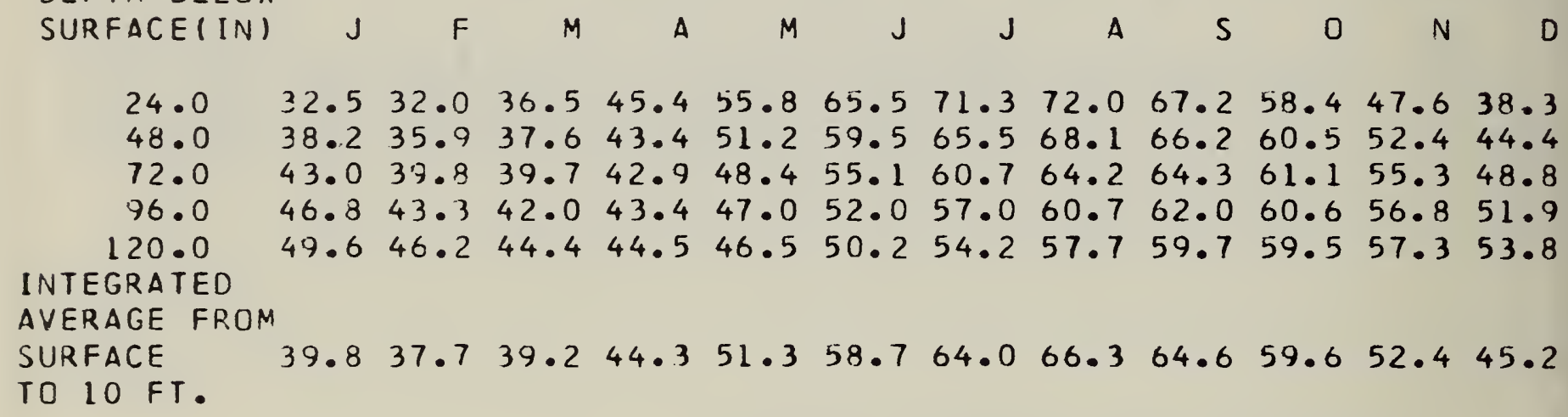

SURFACE (IN)

DEPTH BELOW SURFACE(IN)

INTEGRATED

$$
24.0
$$

48.0

72.0

96.0

120.0

AVERAGE FROM

SURFACE

TO $10 \mathrm{FT}$.

\begin{tabular}{lllll}
\multicolumn{5}{c}{ CIFFUSIVITIES } \\
0.010 & 0.020 & 0.025 & $c .030$ & 0.040 \\
69.8 & 71.6 & 72.0 & 72.4 & 72.8 \\
63.6 & 67.2 & 68.1 & 68.8 & 69.8 \\
58.4 & 62.9 & 64.2 & 65.2 & 66.6 \\
54.7 & 59.2 & 60.7 & 61.8 & 63.6 \\
52.5 & 56.2 & 57.7 & 58.9 & 60.8
\end{tabular}

62.0

65.3

66.3

$67 \cdot 1$

68.2 
EARTH TEMPERATURF STATION

TYPE OF SOIL

TYPE CF EARTH SURFAS,E

DATA PROCESSED BY

DATA SOURCE

PERIOC OF OBSERVATIINN
BURLINGTUN, IOWA

SILTY LOAM

CULTIVETED

CLIMATOLOGICAL DATA

$1960-1962$

OESERVED NONTHLY AVERAGE EARTH TEMPERATURES

MONTH OF YEAR

DEPTH BELOW

SURFACE (IN)

$\begin{array}{rlllllllllllll}1.0 & 30.1 & 30.9 & 36.9 & 56.1 & 71.5 & 81.3 & 84.7 & 86.4 & 74.7 & 61.0 & 43.7 & 31.6 \\ 2.2 & 29.8 & 30.9 & 36.9 & 56.8 & 72.1 & 82.5 & 86.2 & 87.8 & 76.1 & 63.1 & 44.4 & 31.7 \\ 4.0 & 30.6 & 31.2 & 36.8 & 55.6 & 70.9 & 81.2 & 85.1 & 86.5 & 75.7 & 62.2 & 44.5 & 32.2 \\ 8.0 & 31.8 & 31.4 & 35.7 & 51.4 & 66.2 & 75.7 & 81.1 & 83.7 & 74.7 & 62.1 & 46.1 & 34.4 \\ 20.0 & 35.2 & 33.0 & 35.3 & 44.9 & 58.6 & 68.2 & 73.1 & 75.0 & 71.7 & 61.7 & 48.9 & 39.6 \\ 40.0 & 41.5 & 38.5 & 38.4 & 43.1 & 54.0 & 62.7 & 67.7 & 71.9 & 71.0 & 64.2 & 54.6 & 45.9 \\ 72.0 & 47.2 & 43.2 & 42.2 & 42.8 & 47.4 & 53.9 & 60.5 & 65.2 & 67.1 & 64.4 & 59.7 & 52.6\end{array}$

DEPTH BELOW

RESLLTS OF LEAST SQUARES ANALYSIS

SURFACE (IN) AVERAGF (A)

$\begin{array}{rr}1.0 & 57.5 \\ 2.2 & 58.3 \\ 4.0 & 57.9 \\ 8.0 & 56.3 \\ 20.0 & 53.9 \\ 40.0 & 54.6 \\ 72.0 & 54.0\end{array}$

AMPLITUDE (B)

$29 \cdot 9$
$30 \cdot 7$
$29 \cdot 8$
$27 \cdot 2$
$21 \cdot 8$
$17 \cdot 3$
$12 \cdot 5$

STANDARD

DEVIATION

3.4

$3 \cdot 3$

3.2

2.8

2.1

1.9

1.0

\section{CALCULATED EARTH TEMPERATURES AT OBSERVED DEPTHS(*)}

\section{DEPTH BELOW}

\section{SURFACE (IN)}

MONTH OF YEAR

$\begin{array}{rlllllllllllll}1.0 & 24.4 & 27.5 & 37.2 & 51.9 & 66.8 & 78.6 & 83.6 & 80.6 & 70.2 & 55.8 & 40.5 & 29.2 \\ 2.2 & 24.8 & 27.7 & 37.1 & 51.6 & 66.3 & 78.0 & 83.1 & 80.4 & 70.3 & 56.2 & 41.1 & 29.8 \\ 4.0 & 25.5 & 28.0 & 36.9 & 51.0 & 65.5 & 77.2 & 82.5 & 80.1 & 70.5 & 56.7 & 41.8 & 30.6 \\ 8.0 & 26.9 & 28.7 & 36.7 & 49.9 & 63.8 & 75.4 & 81.0 & 79.4 & 70.7 & 57.9 & 43.5 & 32.4 \\ 20.0 & 31.0 & 30.9 & 36.5 & 47.2 & 59.4 & 70.4 & 76.8 & 77.1 & 71.0 & 60.6 & 48.0 & 37.4 \\ 40.0 & 37.4 & 35.1 & 37.6 & 44.6 & 53.9 & 63.6 & 70.4 & 72.9 & 70.2 & 63.2 & 53.6 & 44.3 \\ 72.0 & 45.6 & 41.7 & 41.1 & 43.9 & 49.2 & 56.1 & 62.2 & 66.2 & 66.9 & 64.1 & 58.4 & 51.8\end{array}$


CALCULATED EARTH TEMPERATURES AT SELECTED LEPTHS

FOR DIFFUSIVITY $=0.025, \quad A=54.0, B O=30.0$ AND $P O=0.57$

DEPTH BELOW

MUNTH OF YEAR

SURFACE (IN)

$24 \cdot 0$

$31.3 \quad 31.1 \quad 36.6$

$48 \cdot 0$

37.835 .4

437.7

$6 \quad 47.159 .1$

M J

$J$

A S

$0 \quad N$

D

72.0 $43.439 .8 \quad 39$.

44.5

70.1

76.5

$\begin{array}{lllll}77.0 & 71.0 & 60.7 & 48.3 & 37.7\end{array}$

96.0

47.743 .842 .

43.8

50.663.

$\begin{array}{lllllll}69.9 & 72.6 & 70.1 & 63.4 & 53.9 & 44.7\end{array}$

120.0

$51.0 \quad 47.2 \quad 45.2$

44.248 .5

$58.064 .4 \quad 68.2$

$268.064 .2 \quad 57.4 \quad 49.9$

INTEGRATED

AVERAGE FRUM

SURFACE

$39.6 \quad 37.5 \quad 39.5 \quad 45.5 \quad 53.7 \quad 62.1 \quad 68.2 \quad 70.5 \quad 68.3 \quad 62.3 \quad 53.9 \quad 45.8$

TO $10 \mathrm{FT}$.

CALCULATED AUGUST EARTH TEMPERATURE AT SFLECTED DIFFUSIVITIES AND SELECTED DEPTHS

DEPTH BELOW

SURFACE (IN)

$$
\begin{array}{r}
24.0 \\
48.0 \\
72.0 \\
96.0 \\
120.0
\end{array}
$$

I:VTEGRATED

AVERAGE FROM

SURFACE

TO 10 FT.

\begin{tabular}{lclll}
\multicolumn{5}{c}{ DIFFUSIVITIES } \\
0.010 & 0.020 & 0.025 & 0.030 & 0.040 \\
74.5 & 76.5 & 77.0 & 77.3 & 77.8 \\
67.5 & 71.5 & 72.6 & 73.4 & 74.5 \\
61.6 & 66.7 & 68.2 & 69.3 & 70.9 \\
57.3 & 62.5 & 64.2 & 65.5 & 67.5 \\
54.7 & 59.1 & 60.8 & 62.2 & 64.3
\end{tabular}

65.7

69.4

70.5

71.4

72.7 
EARTH TENPERATURE STATIUIN

TYPE CF SOIL

TYPE CF EARTH SURFACE

DATA PROCESSED BY

DATA SUURCE

PERIOO OF OBSERVATIIJN
MANHATTAN, KANSAS

$S T-20$

SILTY CLAY LOAM

BLUE GRASS

CLIMATOLOGICAL DATA

$1960-1962$

OBSFRVED MONTHLY AVERAGE EARTH TEMPERATURES

DEPTH BELOW

SURFACE ( IN)

MCNTH OF YEAR

$\begin{array}{rllllllllllll}4.0 & 29.5 & 32.3 & 37.6 & 51.4 & 66.2 & 76.5 & 80.0 & 79.4 & 71.0 & 60.3 & 45.3 & 36.0 \\ 48.0 & 42.4 & 40.1 & 41.8 & 46.9 & 55.0 & 64.6 & 68.3 & 70.6 & 69.6 & 64.7 & 57.0 & 49.5 \\ 72.0 & 47.3 & 44.7 & 44.0 & 46.6 & 52.3 & 60.1 & 63.5 & 66.5 & 67.1 & 64.4 & 59.4 & 53.5 \\ 96.0 & 51.7 & 46.2 & 45.2 & 46.3 & 50.3 & 56.7 & 59.7 & 63.1 & 64.3 & 63.0 & 59.6 & 54.7\end{array}$

RESLLTS DF LEAST SQUARES ANALYSIS DEPTH BELOW

AVERAGE ( 1$)$

55.8

56.0

55.8

55.2
AMPLITUDE (B)

$$
\begin{array}{r}
25.5 \\
15.5 \\
11.8 \\
9.4
\end{array}
$$

STANDARD

DEVIATION

2.1

1.3

1.1

1.2

CALCULATEC FAYTH TEMPERATURES AT OBSERVED UEPTHS(*)

DEPTH BELOW

SURFACE (IN)
MUNTH OF YEAR

C. 66

1.10

1.33

1.54
D 
CALCULATEC FARTH TEMPERATURES AT SELECTED LEPTHS

FOR DIFFUSIVITY=0.025, $A=55.0, B D=26.0$ AND $P O=0.61$

DEPTH BELOW

SURFACE (IN )

MONTH OF YEAR

$$
\begin{array}{rllllllllllll}
24.0 & 35.6 & 34.9 & 39.3 & 48.2 & 58.6 & 68.4 & 74.3 & 75.1 & 70.3 & 61.6 & 50.8 & 41.5 \\
48.0 & 41.3 & 38.9 & 40.6 & 46.2 & 54.0 & 62.3 & 68.5 & 71.1 & 69.2 & 63.7 & 55.6 & 47.5 \\
72.0 & 46.1 & 42.8 & 42.6 & 45.8 & 51.3 & 57.9 & 63.6 & 67.2 & 67.3 & 64.2 & 58.4 & 52.0 \\
96.0 & 49.9 & 46.3 & 45.0 & 46.3 & 49.9 & 54.9 & 59.9 & 63.6 & 65.0 & 63.6 & 59.9 & 55.0 \\
120.0 & 52.7 & 49.3 & 47.4 & 47.4 & 49.5 & 53.1 & 57.1 & 60.7 & 62.6 & 62.5 & 60.4 & 56.8
\end{array}
$$

INTEGRATED

AVERAGE FROM

SURFACE

$\begin{array}{llllllllllll}42.8 & 40.7 & 42.2 & 47.2 & 54.1 & 61.5 & 67.0 & 69.3 & 67.7 & 62.7 & 55.5 & 48.4\end{array}$ TO $10 \mathrm{FT}$.

CALCULATED AUGUST EARTH TEMPERATURE AT SELECTED DIFFUSIVITIES AND SELECTE!) DEPTHS

DEPTH BELOW

SURFACE (IN)

24.0

48.0

72.0

96.0

120.0

INTEGRATED

AVERAGE FROM

SURFACE

TO $10 \mathrm{FT}$.

\begin{tabular}{lllll}
\multicolumn{5}{c}{ DIFFUSIVITIES } \\
0.010 & 0.020 & 0.025 & 0.030 & 0.040 \\
72.8 & 74.6 & 75.1 & 75.4 & 75.9 \\
66.5 & 70.1 & 71.1 & 71.8 & 72.8 \\
61.4 & 65.8 & 67.2 & 68.2 & 69.6 \\
57.7 & 62.1 & 63.6 & 64.8 & 66.5 \\
55.4 & 59.2 & 60.7 & 61.9 & 63.8
\end{tabular}

65.0

68.3

69.3

70.1

71.2 
EARTH TEMPERATURE STATION

TYPE CF SOIL

TYPE CF EARTH SURFACE

DATA PROCESSED BY.

DATA SOURCE

PERIOD OF OESERVATION
LEXINGTON, KY.

UNKNOWN

E.N.FITTON

REFERENCE ( 4 )

$1922-1927$

OBSERVED MONTHLY AVERAGE EARTH TEMPERATURES

MONTH OF YEAR

\section{DEPTH BELOW}

SURFACE (IN)

$\begin{array}{llllllllllllllll}3.0 & 32.7 & 35.5 & 42.1 & 56.0 & 62.8 & 74.6 & 77.1 & 76.7 & 73.1 & 58.3 & 45.6 & 39.2\end{array}$ $\begin{array}{llllllllllllll}4.0 & 20.4 & 17.3 & 35.4 & 49.8 & 55.6 & 69.4 & 75.4 & 74.6 & 63.3 & 55.8 & 37.6 & 24.4\end{array}$

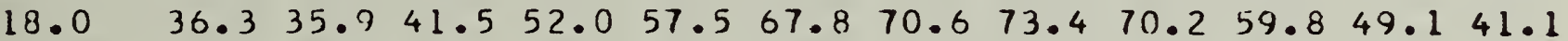

$36.0 \quad 41.8 \quad 40.5 \quad 44.0 \quad 50.3 \quad 56.2 \quad 65.8 \quad 70.5 \quad 73.4 \quad 68.8 \quad 62.0 \quad 53.9 \quad 47.5$

DEPTH BELOW

SURFACEIIN
AVERAGE (A)

56.3

48.4

54.7

56.3

$\begin{array}{rr}3.0 & 56.3 \\ 4.0 & 48.4 \\ 18.0 & 54.7 \\ 36.0 & 56.3\end{array}$

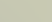

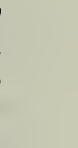

QUARES ANALYSIS

AMPLITUDE (B) PHIASE ANGLE(P)

C. 64
$C .64$
$C .79$
0.94
22.6
28.0
18.8
15.8

STANDARD DEVIATION
1.8

3. 5

1. 5

0.8 
CALCULATEC FARTH TEMPERATURES AT SELECTED DEPTHS

FOR DIFFUSIVITY $=0.025, A=55.0, B D=23.0$ AND $P O=0.60$

DEPTH BELOW

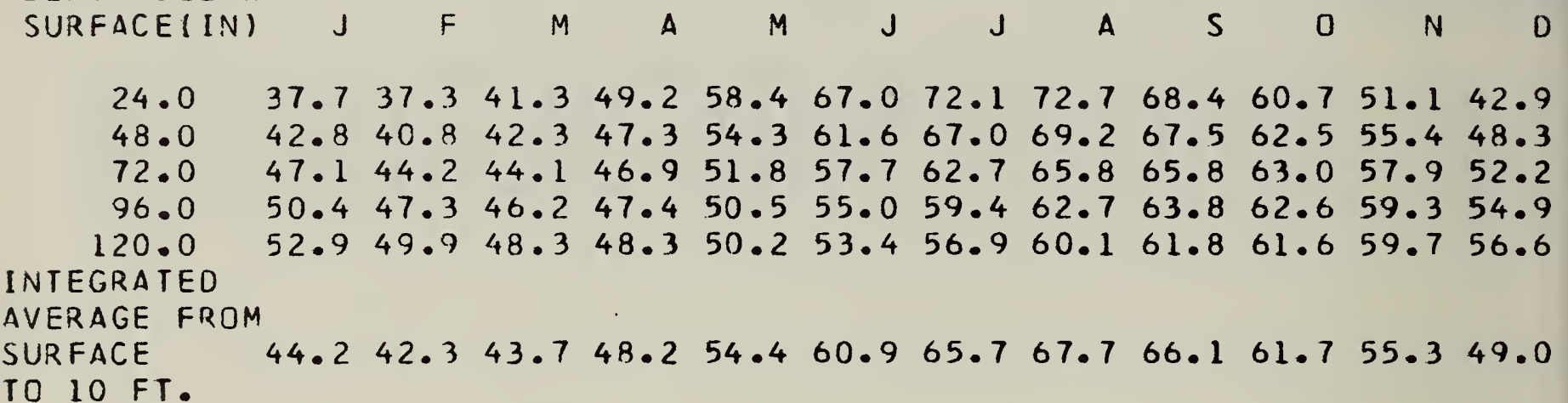

MONTH OF YEAR

CALCULATED AUGUST EARTH TEMPERATURE AT SELECTED DIFFUSIVITIES AND SELECTEN DEPTHS

DEPTH BELOW

SURFACE(IN)

INTEGRATED

$$
24.0
$$

48.0

72.0

96.0

120.0

AVERAGE FROM

SURFACE

TO $10 \mathrm{FT}$.

\begin{tabular}{lclll}
\multicolumn{5}{c}{ DIFFUSIVITIES } \\
0.010 & 0.020 & 0.025 & C.030 & 0.040 \\
70.7 & 72.3 & 72.7 & 73.0 & 73.4 \\
65.2 & 68.4 & 69.2 & 69.9 & 70.7 \\
60.7 & 64.6 & 65.8 & 66.7 & 67.9 \\
57.4 & 61.4 & 62.7 & 63.7 & 65.2 \\
55.4 & 58.8 & 60.1 & 61.1 & 62.8 \\
& & & & \\
63.9 & 66.8 & 67.7 & 68.3 & 69.3
\end{tabular}




\section{EARTH TEMPERATURE STATION}

TYPE CF SOIL

TYPE CF EARIH SURFACE

DATA PROCESSED BY.

DATA SOURCE

PERIOC OF DESERVATION
LEXINGTON, KY

SILTY CLAY

SOC

E.B.PENRUD

REFERENCE $(8,9)$

1952-1956

OBSERVED NONTHLY AVERAGF. EARTH TEMPERATURES

DEPTH BELOW

SURFACE (IN)

MONTH OF YEAR

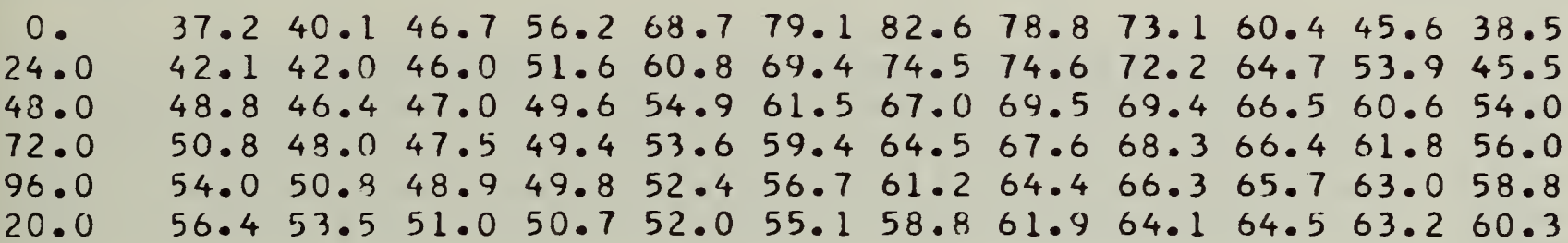

RESLLTS OF LEAST SQUARES ANALYSIS

DEPTH BELOW

SURFACE (IN)

$A V E R A G E(A)$

AMPLITUDE ( B

PHASE ANGLE(P)

STANUARD

$\begin{array}{cc}0 . & 59.0 \\ 24.0 & 58.2 \\ 48.0 & 58.0 \\ 72.0 & 57.8 \\ 96.0 & 57.7 \\ 20.0 & 57.6\end{array}$
23.2
17.2
12.0
10.6
8.7
7.0

C. 56

0.85

1.26

1.42

1.68

1.94
DEVIATION

3.0

2.0

1.6

1.3

1. 3

1.2

CALCULATEC EARTH TEMPERATURES AT OBSERVED CEPTHS (*)

DEPTH BELOW

TEMPERATURES AT OBSERVED CEP
MONTH OF YEAR

SURFACE (IN)

0.

24.0

48.0

72.0

96.0

120.0 $\begin{array}{lllll}36.5 & 37.0 & 42.7 & 52.8 & 64.0\end{array}$

$42.240 .6 \quad 43.350 .158$

47.244 .344 .949 .155 .5

51.247 .847 .049 .253 .6

$54.350 .9 \quad 49.350 .052 .8$

56.653 .451 .551 .152 .7

M

J 


\section{CALCULATED EARTH TEMPERATURES AT SELECTED LEPTHS}

FOR DIFFUSIVITY $=0.025, A=58.0, B O=22.0$ AND $P D=0.75$

DEPIH BELOW

SURFACE(IN)

MONTH OF YEAR

$\begin{array}{llllllllllll} & F & M & A & M & J & J & A & S & 0 & N & D\end{array}$

$24.0 \quad 42.5 \quad 40.7 \quad 43.3 \quad 50.0 \quad 58.7 \quad 67.4 \quad 73.3 \quad 75.3 \quad 72.4 \quad 65.8 \quad 56.9 \quad 48.5$

$\begin{array}{lllllllllllll}48.0 & 47.5 & 44.6 & 45.1 & 49.0 & 55.3 & 62.5 & 68.2 & 71.4 & 70.8 & 66.9 & 60.4 & 53.4\end{array}$

$\begin{array}{lllllllllllll}72.0 & 51.6 & 48.2 & 47.3 & 49.2 & 53.4 & 59.0 & 64.1 & 67.8 & 68.7 & 66.7 & 62.3 & 56.9\end{array}$

$\begin{array}{lllllllllllll}96.0 & 54.7 & 51.3 & 49.7 & 50.1 & 52.7 & 56.8 & 61.1 & 64.6 & 66.4 & 65.8 & 63.1 & 59.2\end{array}$

$120.0 \quad 57.0 \quad 53.7 \quad 51.9 \quad 51.4 \quad 52.7 \quad 55.5 \quad 58.962 .1 \quad 64.2 \quad 64.6 \quad 63.2 \quad 60.4$

INTEGRATED

AVERAGE FRCM

SURFACE $\quad 48.7 \quad 46.1 \quad 46.5 \quad 50.0 \quad 55.6 \quad 62.0 \quad 67.1 \quad 69.9 \quad 69.4 \quad 65.960 .1 \quad 53.9$ TO $10 \mathrm{FT}$.

\section{CALCULATED AUGUST EARTH TEMPERATURE AT SELECTED DIFFUSIVITIES} AND SELECTED DEPTHS

DEPTH BELOW

SURFACE (IN)

INTEGRATED

$$
\begin{array}{r}
24.0 \\
48.0 \\
72.0 \\
96.0 \\
120.0
\end{array}
$$

AVERAGE FROM

SURFACE

TO $10 \mathrm{FT}$.

\begin{tabular}{lllll}
\multicolumn{5}{c}{ DIFFUSIVITIES } \\
0.010 & 0.020 & 0.025 & 0.030 & 0.040 \\
73.0 & 74.8 & 75.3 & 75.6 & 76.1 \\
67.2 & 70.5 & 71.4 & 72.1 & 73.0 \\
62.7 & 66.6 & 67.8 & 68.7 & 70.0 \\
59.6 & 63.4 & 64.6 & 65.7 & 67.2 \\
57.9 & 60.9 & 62.1 & 63.1 & 64.8
\end{tabular}

66.1

69.0

69.9

70.6

71.6 
EARTH TEMPERATURE STATION

TYPE CF SOIL

IYPE OF EARTH SURFACE

DATA PROCESSED BंY

DATA SOURCE

PERIOC OF OESERVATION
UPPER MARLBORD, MD. SANDY LOAM

BARE

US WEATHER R.C.

$1960-1962$

OBSERVED MONTHLY AVERAGE EARTH TEMPERATURES

UEPTH BELOW

MONTH OF YEAR

SURFACE (IN)

$\begin{array}{rlllllllllllll}2.0 & 33.0 & 37.0 & 40.0 & 53.0 & 67.0 & 74.5 & 77.0 & 78.0 & 73.5 & 58.0 & 43.3 & 34.0 \\ 3.9 & 33.0 & 36.5 & 40.0 & 53.0 & 66.5 & 74.5 & 77.0 & 78.0 & 74.5 & 58.7 & 44.3 & 34.7 \\ 7.8 & 34.0 & 37.0 & 41.0 & 53.0 & 67.5 & 73.0 & 76.5 & 77.5 & 74.5 & 59.7 & 46.0 & 36.0 \\ 19.7 & 35.5 & 36.5 & 40.0 & 52.0 & 66.5 & 72.5 & 75.5 & 76.5 & 74.5 & 60.7 & 48.0 & 38.3 \\ 39.4 & 38.5 & 36.5 & 39.0 & 48.0 & 60.5 & 67.0 & 70.0 & 72.0 & 71.0 & 62.7 & 52.7 & 43.5 \\ 59.1 & 42.5 & 39.0 & 40.0 & 47.0 & 58.0 & 64.0 & 67.0 & 69.5 & 69.5 & 64.3 & 56.0 & 48.0\end{array}$

DEPTH BELOW

RESULTS OF LEAST SQUARES ANALYSIS

SURFACE (IN) AVERAGE (A)

$\begin{array}{rr}2.0 & 55.8 \\ 3.9 & 55.9 \\ 7.8 & 56.4 \\ 19.7 & 56.5 \\ 39.4 & 55.3 \\ 59.1 & 55.6\end{array}$

AMPLITUDE (B)

PHASE ANGLE(P)

$24 \cdot 1$
$24 \cdot 1$
$23 \cdot 2$
$22 \cdot 2$
$18 \cdot 3$
$15 \cdot 5$
C. 60

0.62

C. 64

0.70

C. 90

1.05
STANDARD

DEVIATION

2.9
2.9
2.8
2.4
2.0
1.9

CALCULATED EARTH TEMPERATURES AT OBSERVED CEPTHS(*)

DEPTH BELOW

SURFACE (IN)
MONTH OF YEAR

\begin{tabular}{|c|c|c|c|c|c|c|c|c|c|c|c|}
\hline $\begin{array}{l}2 . \\
3 . \\
7\end{array}$ & $\begin{array}{l}31.8 \\
32.6 \\
35.1 \\
38.9 \\
42.5\end{array}$ & $\begin{array}{l}34.1 \\
34.3 \\
34.6 \\
35.9 \\
38.1 \\
40.6\end{array}$ & $\begin{array}{l}41 \\
41 \\
42\end{array}$ & $\begin{array}{l}54.4 \\
54.1 \\
53.4 \\
51.6 \\
49.5 \\
48.2\end{array}$ & $\begin{array}{l}66 . \\
66 . \\
65 . \\
62 . \\
58 . \\
55 .\end{array}$ & $\begin{array}{l}76.5 \\
76.0 \\
74.9 \\
71.9 \\
67.4 \\
63.7\end{array}$ & $\begin{array}{l}80.5 \\
80.1 \\
79.3 \\
76.8 \\
72.9 \\
69.3\end{array}$ & $\begin{array}{l}78.0 \\
77.8 \\
77.4 \\
76.2 \\
73.9 \\
71.4\end{array}$ & $\begin{array}{l}69.3 \\
69.4 \\
69.6 \\
70.0 \\
69.9\end{array}$ & $\begin{array}{l}57.4 \\
57.7 \\
58.4 \\
60.2 \\
62.4 \\
63.7\end{array}$ & $\begin{array}{l}44.7 \\
45.2\end{array}$ \\
\hline
\end{tabular}


CALCULATED EARTH TEMPERATURES AT SELECTED DEPTHS

FOR DIFFUSIVITY $=0.025, A=56.0, B O=25.0$ AND $P O=0.56$

\section{DEPTH BELOW}

SURFACE (IN)

$$
24.0
$$

48.0

72.0

96.0

120.0

MONTH OF YEAR

\section{INTEGRATED}

AVERAGE FROM

SURFACE TO IO FT.

CALCULATEO AUgust earth TEMPERATURE at SELECTED DIFFUSIVITIES AND SELECTED DEPTHS

DEPTH BELOW

SURFACE (IN)

$$
24.0
$$

48.0

72.0

96.0

120.0

INTEGRATEO

AVERAGE FROM

SURFACE

TO $10 \mathrm{FT}$.

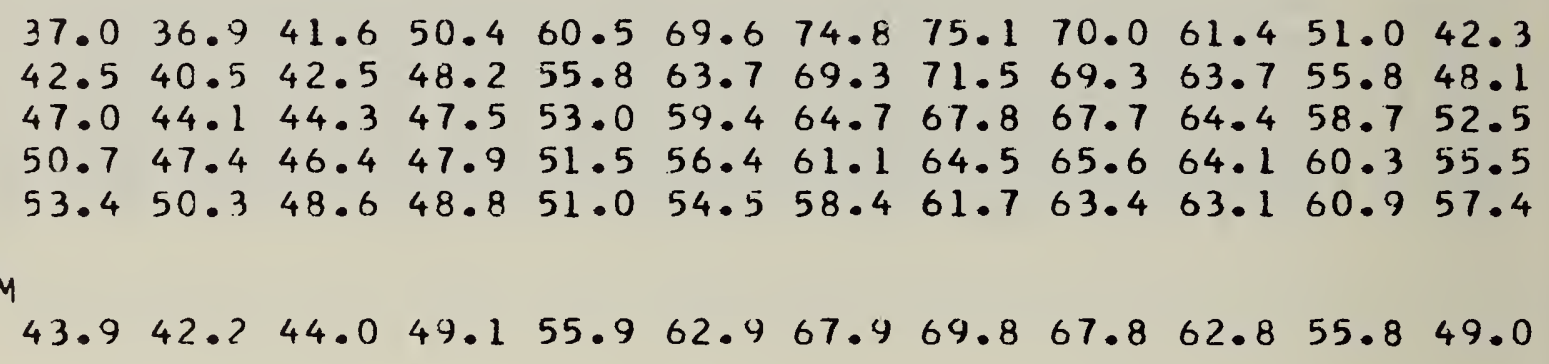


EARTH TEMPERATURE STATION

TYPE CF SOIL

TYPE CF EARTH SURFACE

DATA PROCESSED BY.

DATA SOURCE

PERIOD OF OESERVATION
EAST LANSING,MICH.

$S T-24$

CLAY

UNKNOWN

E. N.FITTON

REFERENCE (4)

$1911-1915$

OBSERVEO MONTHLY AVERAGE EARTH TEMPERATURES

MONTH OF YEAR

UEPTH BELOW

SURFACE (IN)

2.0

$31.9 \quad 32.1$

F $\quad M$

$A M \quad J \quad J$

$\begin{array}{lllll}A & S & O & N & D\end{array}$

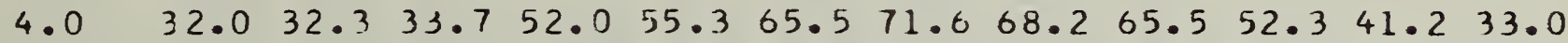

$\begin{array}{lllllllllllll}6.0 & 31.3 & 30.9 & 33.2 & 45.7 & 57.2 & 68.8 & 73.8 & 70.5 & 64.8 & 52.8 & 41.2 & 34.4\end{array}$

$\begin{array}{lllllllllllllll}12.0 & 32.7 & 31.7 & 32.9 & 42.3 & 55.5 & 67.0 & 72.2 & 70.2 & 64.6 & 53.5 & 42.2 & 36.6\end{array}$

$18.0 \quad 34.2 \quad 32.8 \quad 33.3 \quad 41.5 \quad 54.2 \quad 65.3 \quad 70.969 .8 \quad 64.9 \quad 55.1 \quad 43.9 \quad 38.2$

DEPTH BELOW'

RESLLTS OF LEAST SQUARES ANALYSIS

SURFACE (IN)

$\operatorname{AVERAGF}(A)$

AMPLITUDE (B

PHASE ANGLE(P)

21.8
20.5
22.1
20.9
19.8
C. 62

C. 66

0.69

C. 77

C. 83
STANDARD

DEVIATION

3.0

2.6

1.8

2.1

2.0 
CALCULATEC EARTH TEMPERATURES AT SELECTED DEPTHS

FOR DIFFUSIVITY $=0.025, A=50.0, B D=24.0$ AND $P 0=0.60$

\section{DEPTH BELOW}

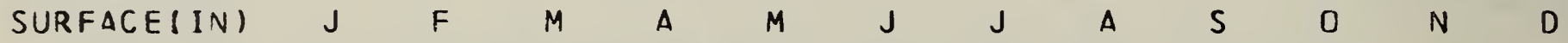

$$
\text { MONTH OF YEAR }
$$

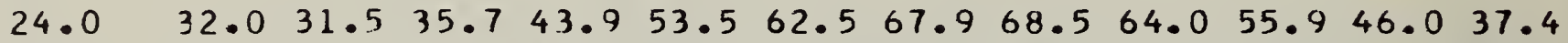

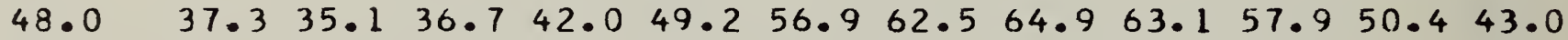

$$
\begin{aligned}
& \begin{array}{lllllllllllllll}
72.0 & 41.7 & 38.7 & 38.6 & 41.6 & 46.7 & 52.8 & 58.1 & 61.3 & 61.3 & 58.4 & 53.1 & 47.1
\end{array}
\end{aligned}
$$

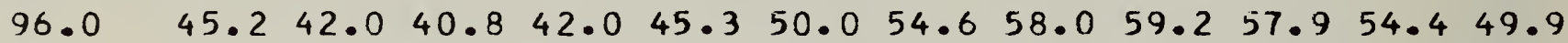

$$
\begin{aligned}
& 120.0 \quad 47.8 \quad 44.7 \quad 43.0 \quad 43.0 \quad 45.0 \quad 48.3 \quad 52.0 \quad 55.3 \quad 57.1 \quad 56.954 .9 \quad 51.6
\end{aligned}
$$
INTEGRATED

AVERAGE FROM

SURFACE

$\begin{array}{llllllllllll}38.7 & 36.8 & 38.2 & 42.9 & 49.3 & 56.1 & 61.1 & 63.2 & 61.6 & 57.0 & 50.3 & 43.8\end{array}$ TO $10 \mathrm{FT}$.

CALCULATEC AUGUST EARTH TEMPERATURE AT SELECTED DIFFUSIVITIES AND SELECTED DEPTHS

DEPTH BELOW

SURFACE (IN)

24.0

48.0

72.0

96.0

120.0

I NTEGRATED

AVERAGE FROM

SURFACE

TO $10 \mathrm{FT}$.

\begin{tabular}{lclll}
\multicolumn{5}{c}{ DIFFUSIVITIES } \\
0.010 & 0.020 & 0.025 & 0.030 & 0.040 \\
66.4 & 68.1 & 68.5 & 68.8 & 69.2 \\
60.7 & 64.0 & 64.9 & 65.5 & 66.4 \\
55.9 & 60.1 & 61.3 & 62.2 & 63.5 \\
52.5 & 56.6 & 58.0 & 59.1 & 60.7 \\
50.4 & 53.9 & 55.3 & 56.4 & 58.1 \\
& & & & \\
59.3 & 62.3 & 63.2 & 63.9 & 65.0
\end{tabular}


EARTH TEMPERATURE STATION

TYPE CF SOIL

TYPE OF EARTH SURFACE

DATA PROCESSED BY

DATA SOURCE

PERIOD OF OBSERVATION
EAST LANSING, MICH.

$S T-25$

GR AVEL

UNKNOWN

E. N.FITTON

REFERENCE (4)

$1911-1915$

OBSERVED MOVTHLY AVERAGE EARTH TEMPERATURES

DEPTH BELOW

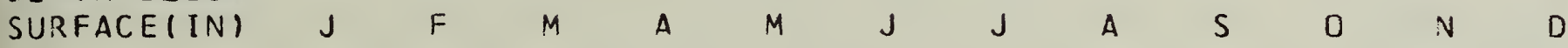

$\begin{array}{llllllllllllllll}2.0 & 31.8 & 32.7 & 34.3 & 56.2 & 58.5 & 69.8 & 75.7 & 70.5 & 67.7 & 53.7 & 41.4 & 32.3\end{array}$

$\begin{array}{lllllllllllllll}4.0 & 32.3 & 32.7 & 34.4 & 54.8 & 57.8 & 67.9 & 74.2 & 69.4 & 66.7 & 53.6 & 41.7 & 33.0\end{array}$

$\begin{array}{llllllllllllll}6.0 & 31.2 & 31.0 & 33.6 & 47.6 & 58.4 & 70.4 & 75.0 & 71.5 & 65.4 & 53.2 & 40.9 & 34.2\end{array}$

$\begin{array}{lllllllllllllll}12.0 & 32.1 & 31.4 & 33.5 & 44.0 & 56.6 & 68.7 & 73.6 & 71.0 & 64.7 & 53.6 & 41.6 & 35.8\end{array}$

$\begin{array}{lllllllllllllll}18.0 & 33.7 & 32.8 & 33.7 & 42.8 & 55.0 & 66.8 & 72.2 & 70.4 & 64.9 & 54.6 & 43.1 & 37.6\end{array}$

RESLLTS OF LEAST SQUARES ANALYSIS

DEPTH BELOW

SURFACE(IN) AVERAGF(A)

$\begin{array}{rr}2.0 & 52.1 \\ 4.0 & 51.6 \\ 6.0 & 51.1 \\ 12.0 & 50.7 \\ 18.0 & 50.7\end{array}$

AMPLITUDE (B)

$$
\begin{aligned}
& 22.6 \\
& 21.5 \\
& 22.7 \\
& 21.7 \\
& 20.3
\end{aligned}
$$

STANDARD DEVIATION

$$
\begin{aligned}
& \text { C. } 61 \\
& 0.62 \\
& C .66 \\
& 0.72 \\
& c .79
\end{aligned}
$$

3.2

2.9

1.8

2.0

2.0 
CALCULATED EARTH TEMPERATURES AT SELECTED DEPTHS

FOR DIFFUSIVITY $=0.025, \quad A=51.0, B O=24 . C$ AND $P D=0.59$

\section{MUNTH OF YEAR}

\section{DEPTH BELOW \\ SURFACE (IN)}

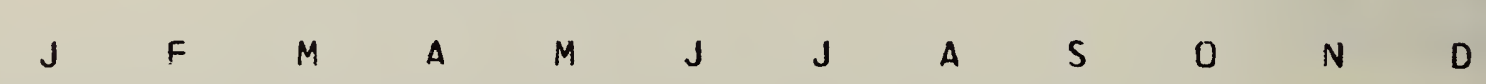

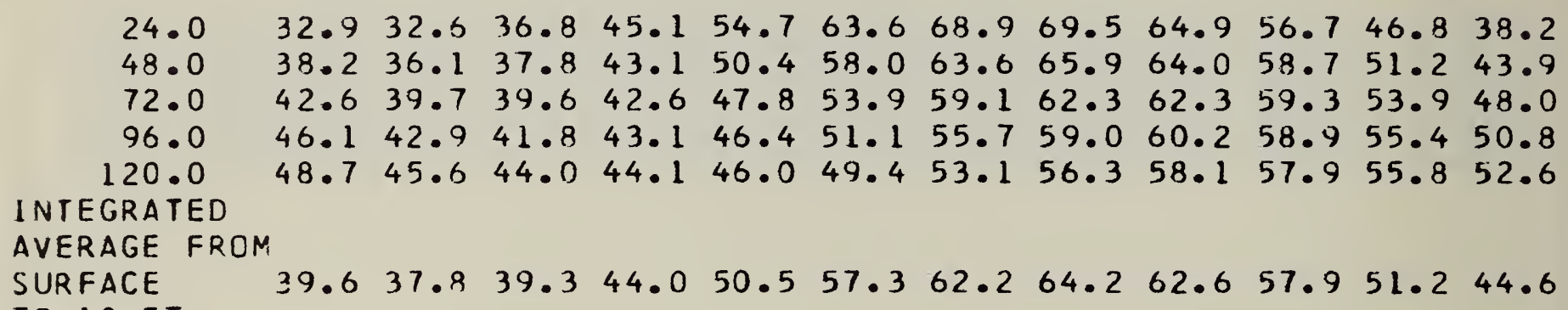

CALCULATEC AUGUST EARTH TEMPERATURE AT SELECTED DIFFUSIVITIES AND SELECTED DEPTHS

DEPTH BELOW

SURFACE(IN)

24.0

48.0

72.0

96.0

120.0

INTEGRATED

AVERAGE FROM

SURFACE

TO $10 \mathrm{FT}$.

\begin{tabular}{lllll}
\multicolumn{5}{c}{ DIFFUSIVITIES } \\
0.010 & 0.020 & 0.025 & 0.030 & 0.040 \\
67.4 & 69.1 & 69.5 & 69.8 & 70.2 \\
61.7 & 65.0 & 65.9 & 66.5 & 67.4 \\
57.0 & 61.1 & 62.3 & 63.2 & 64.5 \\
53.6 & 57.7 & 59.0 & 60.1 & 61.7 \\
51.5 & 55.0 & 56.3 & 57.4 & 59.2
\end{tabular}

$60 \cdot 3$

63.3

$64 \cdot 2$

64.9

65.9 
EARTH TEMPERATURE STATION

TYPE OF SOIL

TYPE CF EARTH SURFAC.E

DATA PROCESSED BY

DATA SOURCE

PERICD OF DESERVATION
EAST LANSING, MICH.

$S T-26$

UNKNOWN

E. N.FITTON

REFERENCE (4)

$1914-1916$

\section{OBSERVED MCNTHLY AVERAGE EARTH TEMPERATURES}

DEPTH BELOH'

MONTH OF YEAR

$\begin{array}{llllllllllll}\text { SURFACE(IN) } J & F & M & A & M & J & J & A & S & 0 & N & D\end{array}$

$\begin{array}{llllllllllllllll}2.0 & 31.3 & 31.5 & 33.3 & 55.2 & 57.0 & 67.9 & 73.4 & 68.5 & 67.2 & 53.4 & 41.0 & 32.5\end{array}$

$\begin{array}{llllllllllllll}4.0 & 32.0 & 32.1 & 33.9 & 53.0 & 56.4 & 66.4 & 72.8 & 68.1 & 65.9 & 52.8 & 41.4 & 33.6\end{array}$

$\begin{array}{lllllllllllllll}6.0 & 30.8 & 30.4 & 32.6 & 45.4 & 57.0 & 68.9 & 74.0 & 70.6 & 64.8 & 52.6 & 40.7 & 34.2\end{array}$

$\begin{array}{llllllllllllllll}12.0 & 32.7 & 31.7 & 32.5 & 42.0 & 55.5 & 67.6 & 73.0 & 70.9 & 65.1 & 54.1 & 42.4 & 36.7\end{array}$

$18.0 \quad 34.5 \quad 33.1 \quad 33.1 \quad 40.8 \quad 53.1 \quad 64.3 \quad 70.2 \quad 69.3 \quad 64.5 \quad 55.1 \quad 44.0 \quad 38.6$

RESLLLTS IJF LEAST SQUARES ANALYSIS

DEPTH BELOW SURFACE(IN) AVERAGF(A)

$\begin{array}{rr}2.0 & 51.1 \\ 4.0 & 50.8 \\ 6.0 & 50.3 \\ 12.0 & 50.5 \\ 18.0 & 50.2\end{array}$

AMPLITUDE (B)

PHASE ANGLE(P)
$21 \cdot 8$
20.8
22.4
21.4
19.4

ST ANDARD

DEVIATION

C. 63
0.64
$C .69$
0.78
C. .86

$3 \cdot 3$

2.7

1.8

2.3

$2 \cdot 1$ 


\section{CALCULATEC FARTH TEMPERATURES AT SELECTED DEPTHS}

FOR DIFFUSIVITY $=0.025, A=50.0, B O=24 . C$ AND $P D=0.60$

DEPTH BELOW

SURFACE(IN)

$$
\text { MONTH OF YEAR }
$$

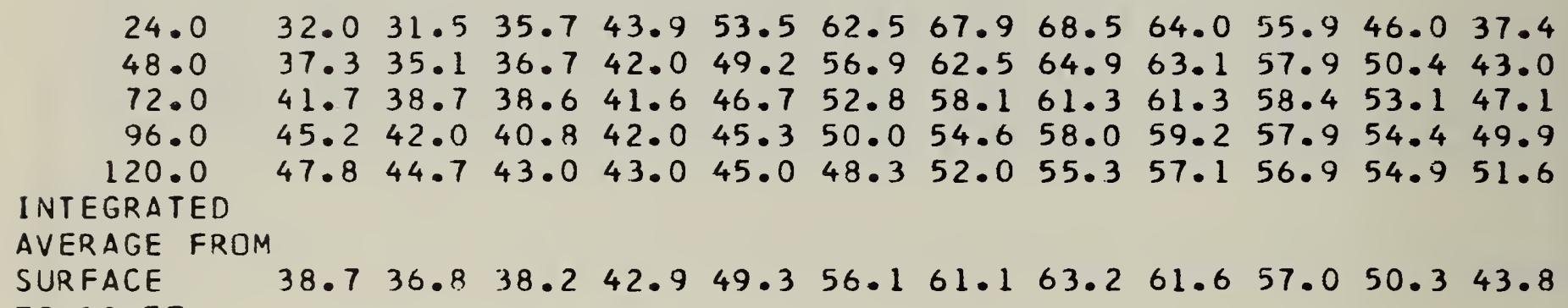

CALCULATED AUGUST EARTH TEMPERATURE AT SELECTED DIFFUSIVITIES AND SELECTED DEPTHS

DEPTH BELOW

SURFACE (IN)

$$
\begin{array}{r}
24.0 \\
48.0 \\
72.0 \\
96.0 \\
120.0
\end{array}
$$

INTEGRATED

AVERAGE FROM

SURFACE

TO $10 \mathrm{FT}$.

\begin{tabular}{lclll}
\multicolumn{5}{c}{ DIFFUSIVITIES } \\
0.010 & 0.020 & 0.025 & 0.030 & 0.040 \\
& & & & \\
66.4 & 68.1 & 68.5 & 68.8 & 69.2 \\
60.7 & 64.0 & 64.9 & 65.5 & 66.4 \\
55.9 & 60.1 & 61.3 & 62.2 & 63.5 \\
52.5 & 56.6 & 58.0 & 59.1 & 60.7 \\
50.4 & 53.9 & 55.3 & 56.4 & 58.1
\end{tabular}

59.3

62.3

63.2

63.9

65.0 
EARTH TEMPERATURE STATION

TYPE CF SOIL

TYPE CF EARTH SURFACE

DATA PROCESSED BY

DATA SOURCE

PERIOD OF OPSERVATION
EAST LANSING,MICH.

PEAT

UNKNOWN

E.M.FITTON

REFERENCE (4)

$1911-1915$

OBSERVED MONTHLY AVERAGE EARTH TEMPERATURES

\section{DEPTH BELOW}

SURFACE ( IN)

$$
\text { MONTH DF YEAR }
$$

$\begin{array}{rllllllllllll}2.0 & 32.0 & 31.9 & 31.9 & 49.9 & 56.7 & 67.5 & 74.2 & 69.4 & 66.9 & 52.9 & 40.5 & 33.3 \\ 4.0 & 31.9 & 31.7 & 31.6 & 46.6 & 55.0 & 64.6 & 71.5 & 67.5 & 64.7 & 51.5 & 40.7 & 34.0 \\ 6.0 & 30.8 & 30.4 & 31.4 & 41.1 & 56.8 & 68.5 & 73.9 & 71.0 & 65.1 & 52.9 & 40.9 & 34.7 \\ 12.0 & 32.6 & 31.6 & 31.9 & 38.6 & 54.7 & 66.9 & 72.1 & 71.3 & 65.6 & 54.8 & 42.8 & 36.6 \\ 18.0 & 35.2 & 33.7 & 33.4 & 37.8 & 53.2 & 64.5 & 70.8 & 70.3 & 65.6 & 56.4 & 45.2 & 39.2\end{array}$

DEPTH BELOW

RESLLTS OF LEAST SQUARES ANALYSIS SURFACE (IN)

AVER $\triangle G E(A)$

50.7

49.4

49.9

50.1

50.5

\section{AMPLITUDE ( 8 )}

$21 \cdot 9$
$20 \cdot 5$
$22 \cdot 6$
$21 \cdot 5$
19.7
STANDARD

DEVIATION

$C .68$
0.71
$C .74$
0.83
$C .90$

2.7

2.2

2.5

2.6

2.6 
CALCULATED EARTH TEMPERATURES AT SELECTED DEPTHS

FOR DIFFUSIVITY $=0.025, A=50.0, B O=24 . C$ AND $P O=0.60$

DEPTH BELOW

SURFACE (IN) MONTH OF YEAR

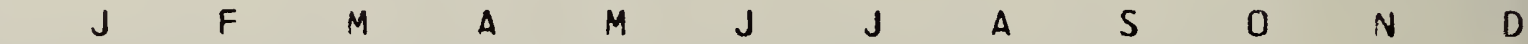

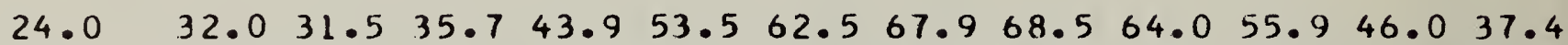
$\begin{array}{llllllllllllll}48.0 & 37.3 & 35.1 & 36.7 & 42.0 & 49.2 & 56.9 & 62.5 & 64.9 & 63.1 & 57.9 & 50.4 & 43.0\end{array}$ $\begin{array}{llllllllllllll}72.0 & 41.7 & 38.7 & 38.6 & 41.6 & 46.7 & 52.8 & 58.1 & 61.3 & 61.3 & 58.4 & 53.1 & 47.1\end{array}$

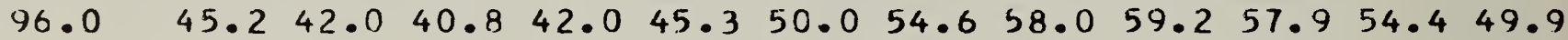

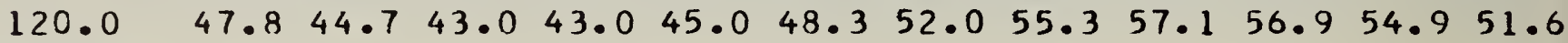
INTEGRATED AVERAGE FROM $\begin{array}{llllllllllllllllll}\text { SURFACE } & 38.7 & 36.8 & 38.2 & 42.9 & 49.3 & 56.1 & 61.1 & 63.2 & 61.6 & 57.0 & 50.3 & 43.8\end{array}$ TO $10 \mathrm{FT}$.

CALCULATEC AUGUST EARTH TEMPERATURE AT SELECTED DIFFUSIVITIES AND SELECTED DEPTHS

DEPTH BELOW

SURFACE(IN)

$24 \cdot 0$

48.0

72.0

96.0

120.0

I NTEGRATED

AVERAGE FROM

SURFACE

TO $10 \mathrm{FT}$.

\begin{tabular}{lcccc}
\multicolumn{5}{c}{ DIFFUSIVITIES } \\
0.010 & 0.020 & 0.025 & 0.030 & 0.040 \\
66.4 & 68.1 & 68.5 & 68.8 & 69.2 \\
60.7 & 64.0 & 64.9 & 65.5 & 66.4 \\
55.9 & 60.1 & 61.3 & 62.2 & 63.5 \\
52.5 & 56.6 & 58.0 & 59.1 & 60.7 \\
50.4 & 53.9 & 55.3 & 56.4 & 58.1 \\
& & & & \\
59.3 & 62.3 & 63.2 & 63.9 & 65.0
\end{tabular}


EARTH TEMPERATURE STATION

TYPE CF SOIL

TYPE CF EARTH SURFACE

DATA PROCFSSED BY

DATA SOUR.CE

PERIDD OF OESERVATION
EAST LANSING, MICH.

$S T-28$

$S A \wedge D$

UNKNOWN

E.M.FITTON

REFERENCE (4)

$1911-1915$

OBSERVED NONTHLY AVERAGE EARTH TEMPERATURES

DEPTH BELOW

SURFACE (IN)

MONTH OF YEAR

\begin{tabular}{|c|c|c|c|c|c|c|c|c|c|c|c|c|}
\hline $\begin{array}{l}2.0 \\
4.0 \\
6.0 \\
2.0 \\
8.0\end{array}$ & $\begin{array}{l}30.6 \\
31.3 \\
30.5 \\
32.2 \\
34.3\end{array}$ & $\begin{array}{l}32.2 \\
32.7 \\
30.5 \\
31.4 \\
33.0\end{array}$ & $\begin{array}{l}34.3 \\
34.5 \\
33.6 \\
33.4 \\
33.9\end{array}$ & $\begin{array}{l}56.2 \\
54.4 \\
47.7 \\
42.9 \\
42.5\end{array}$ & $\begin{array}{l}58.7 \\
58.1 \\
58.5 \\
56.3 \\
54.4\end{array}$ & $\begin{array}{l}70.0 \\
68.6 \\
69.9 \\
67.8 \\
65.5\end{array}$ & $\begin{array}{l}76.2 \\
75.0 \\
74.5 \\
72.8 \\
71.1\end{array}$ & $\begin{array}{l}70.8 \\
70.0 \\
71.4 \\
70.7 \\
69.9\end{array}$ & $\begin{array}{l}68.2 \\
67.4 \\
65.3 \\
64.5 \\
64.8\end{array}$ & $\begin{array}{l}54.1 \\
54.0 \\
53.0 \\
53.6 \\
55.0\end{array}$ & $\begin{array}{l}41.1 \\
41.5 \\
40.5 \\
41.9 \\
43.8\end{array}$ & $\begin{array}{l}30.2 \\
31.8 \\
33.8 \\
36.0 \\
38.3\end{array}$ \\
\hline
\end{tabular}

DEPTH BELOW

RESLLTS OF LEAST SQUARES ANALYSIS

SURFACE(IN) AVERAGE (A)

$\begin{array}{rl}2.0 & 52.0 \\ 4.0 & 51.7 \\ 6.0 & 50.9 \\ 12.0 & 50.4 \\ 18.0 & 50.6\end{array}$

AMPLITUDE(B) PHASE ANGLE(P)

STANDARD

DEVIATION
23.3
22.2
22.8
21.4
19.7

C. 60
0.62
$C .66$
0.74
$C .82$

3.2

2.8

1.6

2.0

1.9 
CALCULATEC FARTH TEMPERATURES AT SELECTED CEPTHS

FU? DIFFUSIVITY $=0.025, \quad A=30.0, B O=24 . C$ AND $P O=0.60$

DEPTH BELCIW

SURFACE(In!)

MONTH OF YEAR

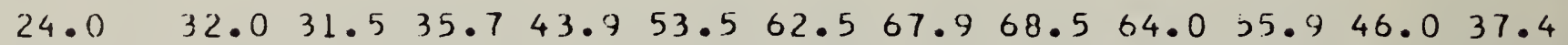

$$
\begin{aligned}
& 48.0 \quad 37.3 \quad 35.1 \quad 36.7 \quad 42.0 \quad 49.2 \quad 56.962 .5 \quad 64.963 .1 \quad 57.9 \quad 50.4 \quad 43.0 \\
& \begin{array}{lllllllllllllll}
72.0 & 41.7 & 38.7 & 38.6 & 41.6 & 46.7 & 52.8 & 58.1 & 61.3 & 61.3 & 58.4 & 53.1 & 47.1
\end{array} \\
& 96.0 \quad 45.2 \quad 42.0 \quad 40.8 \quad 42.0 \quad 45.3 \quad 50.0 \quad 54.6 \quad 58.0 \quad 59.2 \quad 57.9 \quad 54.4 \quad 49.9
\end{aligned}
$$

LINTEGRATEU

AVERAGE FROM

SURFACE $\quad 38.7 \quad 36.3 \quad 38.2 \quad 42.7 \quad 49.3 \quad 56.1 \quad 61.1 \quad 63.2 \quad 61.6 \quad 57.0 \quad 50.3 \quad 43.8$ TO $10 \mathrm{FT}$.

CALCULATEC AUGUST EARTH TEMPERATURE AT SELECTED DIFFUSIVITIES AND SELECTED DEPTHS

UEPTH BELOW SURFACE(IN)

24.0

48.0

72.0

96.0

120.0

INTEGRATED

AVERACE FROM

SURFACE

Ti $10 \mathrm{FT}$.

\section{CIFFUSIVITIES}

$\begin{array}{lllll}0.010 & 0.020 & 0.025 & 0.030 & 0.040\end{array}$

66.4

60.7

55.9

52.5

50.4

68.1
64.0
60.1
56.6
53.9

$68 \cdot 5$

64.9

$61 \cdot 3$

58.0

55.3

68.8

69.2

65.5

62.2

59.1

56.4

66.4

63.5

60.7

$58 \cdot 1$

$\begin{array}{lllll}57.3 & 62.3 & 63.2 & 63.9 & 65.0\end{array}$


EARTH TEMPERATURE STATICN

TYPE CF SOIL

TYPE CF EARTH SURFACE

DATA PROCESSED RY

DATA SOURCF

PERIDC OF ORSERVATION
ST.PAUL, MINN.

SILT LOAM

SOC

CLIMATOLOGICAL DATA

$19 t 1-1962$

DBSERVEO NGVIHLY AVERAGE EARTH TEMPERATURES

DEPTH: HELOH:

SURFACE(IN)

MCNTH OF YEAR

$J \quad F \quad M-A \quad M \quad J \quad J \quad A \quad S \quad O \quad N \quad D$

$\begin{array}{llllllllllllll}0.4 & 25.9 & 28.3 & 32.8 & 43.4 & 64.3 & 74.0 & 77.3 & 76.4 & 64.7 & 34.3 & 38.0 & 31.8\end{array}$

$\begin{array}{llllllllllllll}1 . y & 26.1 & 27.9 & 32.2 & 41.8 & 63.1 & 75.0 & 76.9 & 75.9 & 64.8 & 54.5 & 38.3 & 32.1\end{array}$

$\begin{array}{lllllllllllll}3.9 & 26.6 & 27.8 & 31.8 & 39.7 & 60.7 & 72.6 & 75.2 & 74.6 & 64.5 & 34.5 & 38.8 & 32.7\end{array}$

$\begin{array}{lllllllllllll}7.9 & 27.4 & 27.8 & 31.4 & 34.2 & 56.6 & 68.0 & 72.3 & 71.8 & 63.4 & 53.8 & 39.3 & 34.2\end{array}$

$\begin{array}{lllllllllllllll}15.7 & 29.9 & 30.8 & 31.1 & 34.0 & 52.9 & 63.7 & 68.2 & 69.5 & 63.3 & 54.4 & 41.7 & 35.8\end{array}$

$\begin{array}{lllllllllllllll}31.5 & 33.3 & 30.7 & 32.0 & 33.4 & 48.3 & 58.9 & 65.7 & 68.4 & 63.6 & 56.2 & 43.6 & 34.1\end{array}$

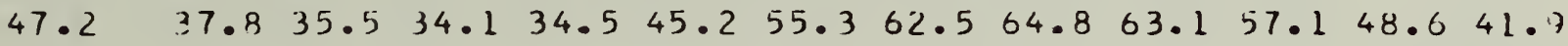

$62.9 \quad 39.5 \quad 37.0 \quad 35.3 \quad 35.2 \quad 43.0 \quad 52.7 \quad 60.162 .962 .4 \quad 57.4 \quad 50.3 \quad 43.8$

$125.9 \quad 45.8 \quad 43.2 \quad 40.940 .140 .7 \quad 45.7 \quad 51.4 \quad 55.6 \quad 57.7 \quad 56.6 \quad 53.3 \quad 49.5$

UEPTH BELOW

RESULTS DF LEAST SQUARES ANALYSIS

SURFACE(IN) AVERAGE (A)

$\begin{array}{rr}0.4 & 51.0 \\ 1.9 & 50.9 \\ 3.9 & 50.1 \\ 7.9 & 48.5 \\ 15.7 & 48.3 \\ 31.5 & 47.9 \\ 47.2 & 48.5 \\ 62.9 & 48.4 \\ 125.9 & 48.4\end{array}$

AMPLITUDE(B) PHASE ANGLE(P)

26.5
26.6
25.6
23.6
20.9
19.1
16.0
14.4
8.8

STANDARD DEVIATION

2.9

3.1

3.1

3.6

2.8

2.7

1.9

1.7

1.0

CALCULATEC EARTH TEMPERATURES AT OBSERVEO CEPTHS(*)

DEPTH BELOW

SURFACE (IN)

MONTH OF YEAR

$\begin{array}{rllllllllllll}0.4 & 23.3 & 25.0 & 32.4 & 44.5 & 57.1 & 67.6 & 72.6 & 71.1 & 63.1 & 51.3 & 38.3 & 28.2 \\ 1.9 & 23.6 & 25.2 & 32.4 & 44.2 & 56.7 & 67.2 & 72.3 & 70.9 & 63.1 & 51.6 & 38.7 & 28.7 \\ 3.9 & 24.1 & 25.5 & 32.3 & 43.8 & 56.1 & 66.6 & 71.8 & 70.6 & 63.2 & 51.9 & 39.3 & 29.3 \\ 7.9 & 25.1 & 26.0 & 32.3 & 43.2 & 55.0 & 65.4 & 70.8 & 70.1 & 63.3 & 52.6 & 40.4 & 30.5 \\ 15.7 & 27.0 & 27.0 & 32.2 & 42.0 & 53.1 & 63.1 & 68.8 & 69.0 & 63.4 & 53.8 & 42.4 & 32.7 \\ 31.5 & 30.7 & 29.3 & 32.6 & 40.3 & 49.8 & 59.1 & 65.1 & 66.7 & 63.1 & 55.6 & 45.7 & 36.8 \\ 47.2 & 34.0 & 31.7 & 33.5 & 39.3 & 47.2 & 55.7 & 61.8 & 64.3 & 62.3 & 56.6 & 48.3 & 40.2 \\ 62.9 & 37.0 & 34.0 & 34.6 & 38.8 & 45.4 & 52.8 & 58.8 & 62.0 & 61.3 & 57.1 & 50.3 & 43.1 \\ 25.9 & 45.5 & 42.0 & 40.2 & 40.3 & 42.5 & 46.2 & 50.3 & 53.9 & 55.9 & 55.7 & 53.4 & 49.7\end{array}$

(*) BASIC PARAMETERS USED fOR the CALCULATION

$A=48.0, P C=25.0, P C=0.65, D=.031$ 
CALCULATEC EARTH TEMPERATURES AT SELECTED CEPTHS FOR DIFFUSIVITY $=0.025, \quad A=48.0, B O=25.0$ A.ND $P O=0.65$

DEPTH BELOW

SURFACE(IN)

\section{MONTH OF YEAR}

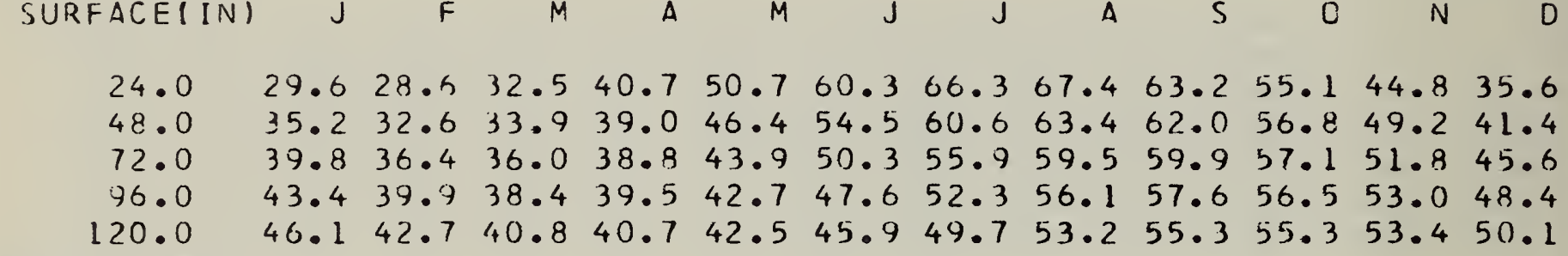
INTEGRATED

AVERAGE FRDM

SURFACE

$\begin{array}{llllllllllllll}36.6 & 34.3 & 35.4 & 40.0 & 46.6 & 53.8 & 59.2 & 61.7 & 60.4 & 55.9 & 49.0 & 42.1\end{array}$ TO $10 \mathrm{FT}$.

CALCULATED AUGUST EARTH TEMPERATURE AT SELECTED DIFFUSIVITIES AND SELECTED DEPTHS

DEEPTH BELOW

SURF $\triangle C E(I N)$

$$
\begin{array}{r}
24.0 \\
48.0 \\
72.0 \\
96.0 \\
120.0
\end{array}
$$

INTEGRATEC

AVERAGE FROM

SURFACE

TO 10 FT.

\begin{tabular}{lclll}
\multicolumn{5}{c}{ CIFFUSIVITIES } \\
0.010 & 0.020 & 0.025 & 0.030 & 0.040 \\
& & & & \\
65.1 & 07.0 & 67.4 & 67.8 & 68.3 \\
58.9 & 62.5 & 63.4 & 64.1 & 65.1 \\
53.9 & 58.3 & 59.3 & 60.5 & 61.9 \\
50.4 & 54.7 & 56.1 & 57.2 & 58.9 \\
48.3 & 31.8 & 53.2 & 54.4 & 56.2
\end{tabular}

$\begin{array}{lllll}57.5 & 60.7 & 61.7 & 62.5 & 63.6\end{array}$ 
FARTH TEMPFRATURE STATIUN

IYPE CF SUIL

TYDE CF EARTH SURFACF

DATA PRUCESSED BY

CATA SOUREE

PERIC. OF MESERVATIMN:
STATE UVIV.MISS.

$S T-30$

CLAY

BARE

CL IMATULOGICAL DATA

$19+0-1962$

\section{CRSERVED VONTHLY AVERAGE EARTH TEMPERATURES}

CEPTH BELOW

MOVTH OF YEAR

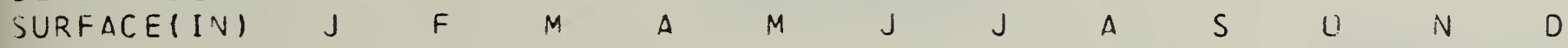

$\begin{array}{rllllllllllll}2.0 & 49.4 & 55.0 & 54.2 & 65.1 & 33.0 & 85.2 & 89.5 & 87.3 & 82.5 & 72.3 & & 48.8 \\ 4.0 & 44.1 & 53.3 & 56.6 & 63.1 & 76.3 & 79.7 & 85.7 & 86.8 & 82.3 & 72.7 & 57.1 & 47.4 \\ 8.0 & 46.4 & 53.2 & 55.5 & 62.1 & 75.3 & 73.4 & 82.8 & 83.9 & 79.9 & 70.0 & 54.9 & 48.9 \\ 16.0 & 46.4 & 53.7 & 53.2 & 61.8 & 74.4 & 80.1 & 84.3 & 84.7 & 81.0 & 72.8 & & 51.4\end{array}$

DEPTH BELCW

RESLLTS OF LEAST SQUARES AVALYSIS SURFACE (IN)

$\triangle V E Q A G E(\Delta)$

AMPLITUDE(B)

PHASE ANGLE(P)

21.0

20.5

18.8

18.7
SI ANUARU

DEVIATION
3.1

4.0

3.1

2.3 
CALCULATEC EARTH TEMPERATURES AT SELECTED CEOTHS

FOK DIFFUSIVITY $=0.025, \quad A=67.0, B O=21 . C$ AND $P O=0.58$

\section{DEPTH BELOW}

SUPFACE(IN)

\section{MOVTH OF YEAR}
24.0
51.150 .4
$\begin{array}{llllllllllllll} & 54.7 & 62.0 & 70.4 & 78.2 & 82.7 & 83.1 & 79.0 & 71.3 & 63.2 & 55.7\end{array}$ $\begin{array}{lllllllllllllll}48.0 & 55.7 & 54.0 & 55.5 & 60.2 & 66.6 & 73.3 & 78.1 & 80.0 & 78.3 & 73.7 & 67.1 & 60.6\end{array}$ $\begin{array}{llllllllllllll}72.0 & 59.6 & 57.1 & 57.1 & 59.9 & 64.3 & 69.7 & 74.2 & 76.9 & 76.8 & 74.2 & 69.5 & 64.2\end{array}$ $\begin{array}{lllllllllllllll}96.0 & 62.7 & 59.9 & 58.9 & 60.1 & 63.1 & 67.2 & 71.1 & 74.1 & 75.0 & 73.9 & 70.7 & 66.7\end{array}$ $120.0 \quad 65.0 \quad 62.3 \quad 60.8 \quad 61.0 \quad 62.7 \quad 65.6 \quad 68.9 \quad 71.7 \quad 73.2 \quad 73.0 \quad 71.2 \quad 68.3$ INTEGRATED AVERAGE FROM
SURFACE $57.0 \quad 55.4 \quad 56.8 \quad 61.0 \quad 66.6 \quad 72.6 \quad 76.9 \quad 78.6 \quad 77.1 \quad 72.9 \quad 67.1 \quad 61.3$ TO 10 FT.

F $\quad M$
$\Delta$
M

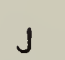

J $A$ S

U N

D

CALCULATFC AUGUST EARTH TEMPERATURE AT SELECTED OIFFUSIVITIES ANI) SELECTEN DEPTHS

CEPTH BELOW ¿URFACE (IV)

24.0

48.0

72.0

96.0

120.0

I YTEGR $\triangle T E D$ AVERAÚE FROM

SURFACE

TO 10 FT.

$\begin{array}{cc} & \text { CIFFUSIVITIES } \\ 0.010 & 0.020 \\ 81.3 & 82.8 \\ 76.4 & 79.3 \\ 72.3 & 75.9 \\ 69.3 & 72.9 \\ 67.4 & 70.5\end{array}$

$75 \cdot 1$

77.8

$78 \cdot 6$

83.1

80.0

76.9

74.1

71.1

0.030

0.040

E3.4

80.6

77.7

75.0

12.7

83.7

81.3

78.8

76.4

74.2 
EARTH TEMPERATURE STATION

TYPE C.F SOIL

TYPE CF EARTH SURFAT,E

LATA PRUCFSSED BY

UATA SUURCE
FALCETT, MO.

UNKNOWN

SOC

JEN-HU-CHANG

REFERENCE ( 5 )

PERIOD OF OPSERVATION

$1951-1952$

DBSERVED NCINTHLY AVERAGE EARTH TEMPERATURES

MONTH OF YEAR

DEPTH BELOW

SURFACE (IN)

$\begin{array}{rllllllllllllll}1.0 & 33.0 & 33.2 & 38.7 & 47.8 & 64.1 & 73.8 & 83.4 & 81.1 & 71.4 & 56.4 & 43.8 & 34.4 \\ 3.0 & 33.2 & 33.6 & 38.0 & 46.3 & 63.0 & 71.1 & 79.9 & 78.3 & 70.2 & 55.8 & 43.6 & 35.1 \\ 6.0 & 33.8 & 33.8 & 37.5 & 45.2 & 62.1 & 69.1 & 76.7 & 76.4 & 69.4 & 56.5 & 44.1 & 36.4 \\ 12.0 & 35.3 & 35.2 & 37.5 & 43.8 & 61.1 & 68.0 & 73.6 & 74.6 & 70.2 & 56.8 & 46.2 & 38.6 \\ 24.0 & 37.2 & 36.0 & 38.5 & 44.3 & 58.0 & 65.3 & 71.1 & 73.6 & 68.0 & 59.5 & 49.2 & 42.4 \\ 48.0 & 43.2 & 41.6 & 41.7 & 44.8 & 53.5 & 60.7 & 65.4 & 67.7 & 66.6 & 62.6 & 55.6 & 48.6 \\ 72.0 & 45.5 & 44.4 & 44.2 & 46.0 & 48.9 & 55.6 & 61.3 & 64.0 & 64.7 & 62.5 & 57.0 & 51.4\end{array}$

DEPTH BELOW

RESLLTS OF IEAST SQUARES ANALYSIS

SURFACE(IN)

$\begin{array}{rl}1.0 & 55.3 \\ 3.0 & 54.1 \\ 6.0 & 53.5 \\ 12.0 & 53.5 \\ 24.0 & 53.7 \\ 48.0 & 54.4 \\ 72.0 & 53.9\end{array}$

$\triangle M P L I T U D E(B)$

PHASE ANGLE(P)

$25 \cdot 6$
$24 \cdot 1$
$22 \cdot 7$
$21 \cdot 0$
$18 \cdot 8$
$13 \cdot 7$
10.8

STANDARD

DEVIATION

0.66
0.69
0.73
0.78
$C .88$
1.14
1.37

C. 66

0.69

C. 73

0.78

1.14

1.37
2.4

2.2

2.1

2.2

1.3

0.7

0.7

CALCULATEC FARTH TEMPERATURES AT OBSERVEO DEPTHS(*)

DEPTH BELOW

SURFACE(IN)

MONTH OF YEAR

$\begin{array}{llllllllllllll}1.0 & 34.4 & 35.7 & 41.5 & 51.1 & 61.1 & 69.5 & 73.5 & 72.4 & 66.1 & 56.8 & 46.4 & 38.4\end{array}$

$\begin{array}{lllllllllllllll}3.0 & 34.9 & 35.9 & 41.5 & 50.7 & 60.5 & 68.9 & 73.0 & 72.1 & 66.2 & 57.1 & 47.0 & 39.0\end{array}$

$\begin{array}{llllllllllllll}6.0 & 35.6 & 36.3 & 41.4 & 50.2 & 59.7 & 68.0 & 72.3 & 71.7 & 66.2 & 57.7 & 47.8 & 39.9\end{array}$

$12.0 \quad 37.1 \quad 37.1 \quad 41.4 \quad 49.3 \quad 58.2 \quad 66.2 \quad 70.8 \quad 70.966 .3 \quad 58.6 \quad 49.4 \quad 41.7$

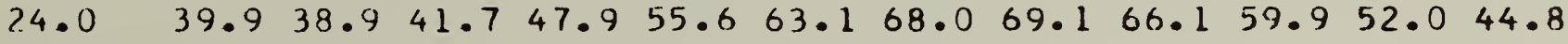

$\begin{array}{lllllllllllllll}48.0 & 44.8 & 42.5 & 43.1 & 46.7 & 52.1 & 58.2 & 63.0 & 65.5 & 64.8 & 61.2 & 55.6 & 49.7\end{array}$

$\begin{array}{llllllllllllllll}72.0 & 48.7 & 45.9 & 45.2 & 46.8 & 50.3 & 54.9 & 59.1 & 62.1 & 62.8 & 61.2 & 57.5 & 53.1\end{array}$ 


\section{CALCULATED EARTH TEMPERATURES AT SELECTED CEPTHS}

FOR DIFFUSIVITY $=0.02 \mathrm{~b}, A=54.0, B O=20.0$ AND $P D=0.65$

CEPTH BELOW

SURFACE(IN) J

MONTH OF YEAR

$24.0 \quad 39.2 \quad 39.5 \quad 41.6 \quad 48.2 \quad 56.2 \quad 63.8 \quad 68.6 \quad 69.6 \quad 66.2 \quad 59.7 \quad 51.4 \quad 44.1$

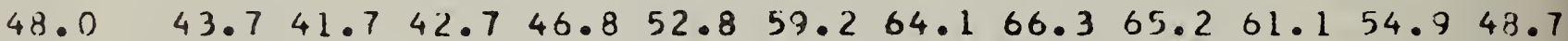
$72.0 \quad 47.5 \quad 44.7 \quad 44.4 \quad 46.6 \quad 50.7 \quad 55.960 .463 .263 .561 .3 \quad 57.0 \quad 52.0$

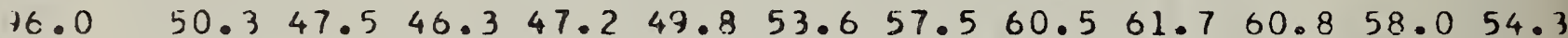

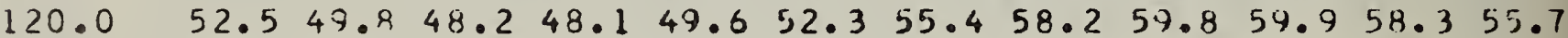
I VTEC: $\triangle T$ TEL

$\triangle V E R A G E$ FRDM

SURFACE $\quad 44.943 .043 .947 .3 \quad 52.758 .6 \quad 63.065 .063 .960 .3 \quad 54.849 .3$ TD $10 \mathrm{FT}$.

CALCULATED AUguSt EARTH TEMPERATURE AT SELECTED DIFFUSIVITIES AND SELECTED DEPTHS

DEPTH BELOW

SURF $\triangle C E([N)$

$$
\begin{array}{r}
24.0 \\
48.0 \\
72.0 \\
96.0 \\
120.0
\end{array}
$$

LIITEGRATED

AVERAGE FROM:

¿URFACE

T ( ) $10 \mathrm{FT}$.
CIFFUSIVITIES

$\begin{array}{lllll}0.010 & 0.020 & 0.025 & 0.030 & 0.040 \\ 67.7 & 69.2 & 69.6 & 69.8 & 70.2 \\ 62.8 & 65.6 & 66.3 & 66.9 & 67.7 \\ 58.7 & 62.2 & 63.2 & 64.0 & 65.2 \\ 55.9 & 57.3 & 60.5 & 61.4 & 62.8 \\ 54.2 & 57.1 & 58.2 & 59.1 & 60.6\end{array}$

61.6

64.2

65.0

65.6

66.5 
EARTH TFNPERATURE STATION

TYPE: CF SCIL

TYPF CF EARTH SURFAC,E

UATA PROCESSED BY

DATA SUURCE

PERIOC UF OJPSERVATION
KANSAS CITY,MC).

$S T-32$

UNKNOWN

JEA-HU-CHANG

REFERENCE(5)

$1950-1952$

\section{TJBSERVED NCNTHLY AVERAGE EARTH TEMPLRATURES}

DEPTH BELOW

SURFACE (IN)

MCNTH UF YEAR

\section{MONTH OF YEAR}

$\begin{array}{llllllllllllllll}3.9 & 34.8 & 41.1 & 41.8 & 54.5 & 70.3 & 77.7 & 75.4 & 75.5 & 71.2 & 61.1 & 48.5 & 34.5\end{array}$

$\begin{array}{lllllllllllllll}7.9 & 35.6 & 37.9 & 41.3 & 52.9 & 63.4 & 75.2 & 73.3 & 76.6 & 67.4 & 58.4 & 47.6 & 36.6\end{array}$

$\begin{array}{llllllllllllll}11.8 & 36.9 & 38.0 & 40.3 & 49.8 & 60.6 & 70.7 & 72.2 & 78.3 & 66.0 & 58.9 & 48.3 & 38.7\end{array}$

$\begin{array}{llllllllllllll}19.7 & 38.1 & 38.7 & 40.2 & 47.7 & 58.0 & 67.0 & 69.8 & 69.1 & 64.9 & 39.4 & 49.7 & 40.8\end{array}$

$\begin{array}{lllllllllllllll}39.4 & 39.5 & 39.7 & 40.9 & 47.1 & 55.4 & 63.7 & 67.7 & 71.2 & 63.1 & 50.1 & 50.6 & 43.0\end{array}$

RESLLTS OF LEAST SQUARES A'VALYSIS

DEPTH BELOW

SURFACE(IN) AVERAGT:(A)

$\begin{array}{rl}3.9 & 57.3 \\ 7.9 & 55.6 \\ 11.8 & 55.0 \\ 19.7 & 53.7 \\ 37.4 & 53.8\end{array}$

AMPLITUDE (B) PHIASE AINGLE(P)

STANDARD

DEVIATION
$22 \cdot 3$
21.1
19.9
16.8
15.8

$C .58$
0.63
$C .72$
0.80
$C .90$

3.1

1.9

2.1

1.2

1.0 
CALCULATEC TARTH TEMPERATURES AT SELECTED DEPTHS

FDR DIFFUSIVITY $=0.025, \quad A=54.0, B O=22 . C$ AND $P O=0.56$

DEPTH BELDW

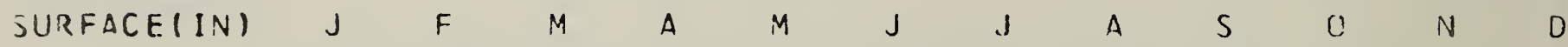

MONTH OF YEAR

$$
24.0 \quad 37.3 \quad 37.2 \quad 41.3 \quad 49.1 \quad 57.9 \quad 66.0 \quad 70.6 \quad 70.8 \quad 66.4 \quad 58.849 .6 \quad 41.9
$$
$\begin{array}{llllllllllllllll}48.0 & 42.1 & 40.4 & 42.1 & 47.1 & 53.9 & 60.8 & 65.7 & 67.6 & 65.7 & 60.8 & 53.8 & 47.1\end{array}$ $\begin{array}{lllllllllllll}72.0 & 46.1 & 43.6 & 43.7 & 46.6 & 51.3 & 57.0 & 61.7 & 64.4 & 64.3 & 61.4 & 56.4 & 50.9\end{array}$

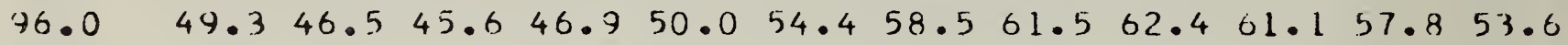
$120.0 \quad 51.7 \quad 47.0 \quad 47.5 \quad 47.7 \quad 49.6 \quad 52.7 \quad 56.1 \quad 59.0 \quad 60.5 \quad 60.3 \quad 58.3 \quad 55.2$ INTEIFRATEO AVERAGE FROM SURFACE. $43.441 .9 \quad 43.447 .753 .960 .164 .466 .164 .460 .053 .847 .9$ TO $10 \mathrm{FT}$.

CALCULATEC AUgust earth temperature at SELECTED DifFiss IVITIES AND SELECTEN DEPTHS

UEPTH BELOW SUR.FACE (IN)

INTFGRATEU

$$
24.0
$$

4 त. 0

72.0

96.0

120.0

AVERAGE FROM SURFACE

TO $10 \mathrm{FT}$.
DIFFUSIVITIES

$\begin{array}{lllll}0.010 & 0.020 & 0.025 & 0.030 & 0.040 \\ 69.0 & 70.4 & 70.8 & 71.1 & 71.4 \\ 63.9 & 66.7 & 67.6 & 68.2 & 67.0 \\ 59.6 & 03.3 & 64.4 & 65.2 & 66.4 \\ 56.5 & 60.3 & 61.5 & 62.5 & 63.9 \\ 54.5 & 57.8 & 59.0 & 60.0 & 61.6\end{array}$

62.6

65.3

66.1

66.8

67.7 
EARTH TEMPERATURE STATION

TYPE CF SOIL

TYPE CF EARTH SURFACE

DATA PROCESSEO HY

DATA SOURCE

PERICU OF OPSERVATION
SIKESTON,MOP

SANDY LDAM

GRASS

CLIMATOLOGICAL DATA

$1960-1962$

OBSLRVED NONTHLY AVERAGE EARTH TEMPERATURES

MONTH OF YEAR

DEPTH BELOW

SURFACE (IN)

\begin{tabular}{|c|c|c|c|c|c|c|c|c|c|c|c|}
\hline .0 & 36.9 & $41 \cdot 1$ & 45.1 & 57.6 & 69.8 & 78.9 & 83.9 & 82.8 & 76.1 & 64.1 & 49.6 \\
\hline 0 & 3 & . 4 & 43.0 & 7.5 & 10.2 & 79.2 & 84.2 & 83.3 & 76.7 & 66.0 & 50.6 \\
\hline - $\mathrm{C}$ & 37.3 & 39.0 & 44.9 & 57.1 & 69.8 & 78.7 & 83.8 & 82.7 & 76.0 & 66.1 & 50.8 \\
\hline 0 & 37.0 & 38.4 & 43.1 & 51.8 & 63.1 & 70.8 & 75.0 & 76.4 & 73.3 & 65.6 & 53.6 \\
\hline .0 & 47.0 & 39.7 & 44.3 & 47.7 & 54.9 & 61.7 & 66.7 & 70.0 & 70.4 & 67.4 & 61.2 \\
\hline
\end{tabular}

RESLLTS OF LEAST SQUARES ANALYSIS

CEPTH BELOW

SURF $\triangle C E(I N)$ AVERAGF (A)

$\begin{array}{rl}1.0 & 60.6 \\ 3.0 & 61.1 \\ 6.0 & 60.8 \\ 24.0 & 57.9 \\ 72.0 & 57.5\end{array}$

AMPLITUDE (B)

PHASE ANGLE(P)

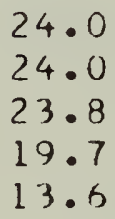

C.63

0.66

0.83

1.29
STANDARD

DEVIATION

3.2

3.1

3.0

2.3

1.2

CALCULATEl; eARTH TEMPERATURES AT UBSERVED DEPTHS(*)

DEPTH BELUW

SURFACE (IN)
MONTH OF YEAR 
CALCULATEC FARTH temperatures at SELECTED CEPTHS

FOR DIFFUSIVITY $=0.023, A=57.0, B O=25.0$ AND $P O=0.59$

DEPTH BELOW

SURFACE(IV)

MONTH OF YEAR

$\begin{array}{lllllllllllll}24.0 & 38.2 & 37.9 & 42.2 & 50.9 & 60.9 & 70.2 & 75.7 & 76.2 & 71.5 & 63.0 & 52.6 & 43.7 \\ 48.0 & 43.7 & 41.5 & 43.3 & 48.8 & 56.4 & 64.3 & 70.1 & 72.5 & 70.5 & 65.1 & 57.2 & 49.6 \\ 72.0 & 48.3 & 45.2 & 45.2 & 48.3 & 53.6 & 60.1 & 65.5 & 68.9 & 68.8 & 65.6 & 60.1 & 53.9 \\ 96.0 & 51.9 & 48.6 & 47.4 & 48.7 & 52.2 & 57.1 & 61.9 & 65.4 & 66.6 & 65.2 & 61.5 & 56.8 \\ 20.0 & 54.0 & 51.4 & 49.7 & 49.8 & 51.8 & 55.3 & 59.2 & 62.5 & 64.4 & 64.2 & 62.1 & 58.6\end{array}$
I VTEC,R $\triangle T E D$

AVERAGE FROMM

SURFACE $\quad 45.2 \quad 43.2 \quad 44.8 \quad 49.7 \quad 36.4 \quad 63.368 .7 \quad 70.8 \quad 69.164 .257 .2 \quad 50.4$ IU IO FT.

\section{CALCULATEC AUGUST EARTH TEMPERATURE AT SELECTED DIFFUSIVITIF.S AND SELECTEN DEPTHS}

DEPTH BELCW

SURFACE(IN)

I VTEGRATEC

$24 \cdot 0$
$48 \cdot 0$
$72 \cdot 0$
$96 \cdot 0$
$120 \cdot 0$

AVERALE FRIMM

SURFACE

TII LO FT.

\begin{tabular}{lclll}
\multicolumn{5}{c}{ DIFFUSIVITIES } \\
0.010 & 0.020 & 0.025 & 0.030 & 0.040 \\
74.1 & 75.8 & 76.2 & 76.5 & 77.0 \\
68.2 & 71.6 & 72.5 & 73.1 & 74.1 \\
63.2 & 67.5 & 68.3 & 69.7 & 71.1 \\
57.7 & 64.0 & 65.4 & 66.5 & 68.2 \\
57.5 & 01.1 & 62.5 & 63.7 & 65.5
\end{tabular}

66.7

69.8

70.8

71.5

$72 \cdot 6$ 
EARTH TEMDFRATURE STATION

TYPE CF SOIL

TYPE CF EAR.TH SURFAC,E

UATA PROCESSED BY

DATA SUURCE

PERICE OF OHSERVATITH
BOLEMAN, MONTANA

UNKNOWN

UN KNDWN

JEN-HU-CHANG

REFERENCE (5)

$1916-1920$

IORSERVEI) NONTHLY AVERAGE EARTH TEMPERATURES

MONTH OF YEAR

UEPTH BELOW

SURFACE (IN)

$\begin{array}{lllllllllllll}12.0 & 29.7 & 27.1 & 30.2 & 35.0 & 44.2 & 55.4 & 64.4 & 62.9 & 55.4 & 44.6 & 35.4 & 31.5 \\ 24.0 & 31.8 & 30.7 & 31.4 & 34.8 & 42.8 & 52.3 & 60.0 & 61.4 & 56.2 & 47.0 & 38.6 & 34.1 \\ 36.0 & 33.5 & 32.2 & 32.0 & 34.1 & 40.0 & 48.7 & 56.1 & 58.1 & 55.1 & 47.6 & 39.9 & 35.6 \\ 48.0 & 36.0 & 34.4 & 33.6 & 34.6 & 38.8 & 46.1 & 53.8 & 57.3 & 55.2 & 49.2 & 42.8 & 39.3 \\ 60.0 & 37.7 & 35.7 & 34.7 & 35.3 & 38.8 & 44.8 & 51.0 & 54.2 & 53.7 & 49.8 & 44.4 & 40.2 \\ 90.0 & 41.2 & 33.3 & 37.9 & 37.4 & 38.7 & 42.0 & 46.6 & 50.8 & 51.9 & 50.0 & 46.4 & 43.4 \\ 20.0 & 41.8 & 39.9 & 38.5 & 37.9 & 38.7 & 41.7 & 46.1 & 50.0 & 51.4 & 50.1 & 46.9 & 43.7\end{array}$

UEPTH BELO'

RESLLTS CF I.FAST SGUARES ANALYSIS

SURFACE (IN)

$A V E R \triangle G F(A)$

43.2

43.5

42.8

43.4

43.4

43.8

43.9
AMPLITUDE (B)

PHASE ANGLE(P)

$17 \cdot 6$
$15 \cdot 4$
$13 \cdot 1$
$11 \cdot 5$
$9 \cdot 7$
$6 \cdot 9$
6.5

1.79
0.92
1.04
1.21
1.33
1.66
1.74

ST ANDARD

DEVIATION

3.2

2.4

2.2

2.1

1.4

1.1

1.0

Calculatec farth temperatures at observed [ePths(

DEPTH BELDW

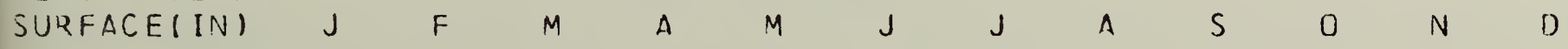

MUNTH OF YEAR

$12.0 \quad 26.8 \quad 26.4 \quad 30.4 \quad 38.3 \quad 47.5 \quad 56.0 \quad 61.1 \quad 61.6 \quad 57.3 \quad 49.5 \quad 40.0 \quad 31.3$

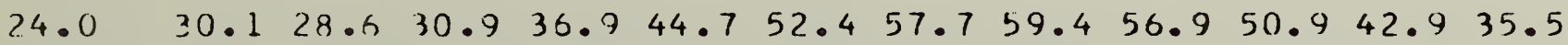

$\begin{array}{llllllllllllll}36.0 & 33.1 & 30.9 & 31.8 & 36.2 & 42.5 & 49.5 & 54.7 & 57.2 & 56.0 & 51.7 & 45.1 & 38.4\end{array}$

$\begin{array}{lllllllllllllll}48.0 & 35.7 & 32.3 & 33.0 & 36.0 & 41.0 & 47.0 & 52.1 & 55.0 & 54.9 & 51.9 & 46.7 & 40.9\end{array}$

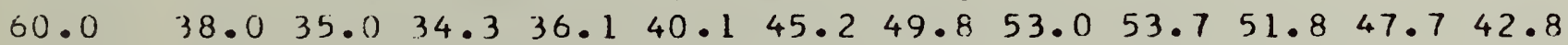

$\begin{array}{llllllllllllll}90.0 & 42.2 & 39.2 & 37.6 & 37.5 & 39.2 & 42.3 & 45.7 & 48.7 & 50.5 & 50.4 & 48.7 & 45.7\end{array}$

$120.0 \quad 44.5 \quad 42.7 \quad 40.4 \quad 39.5 \quad 39.8 \quad 41.3 \quad 43.4 \quad 45.8 \quad 47.7 \quad 48.548 .246 .7$ 
CALCULATEC FARTH TEMPERATURES AT SELECTED CEPTHS

FUR DIFFUSIVITY $=0.025, \quad A=44.0 . B O=21.0$ AND $P O=0.68$

\section{DEPTH BELOW}

SURFACE (IN)

\section{MONTH OF YEAR}

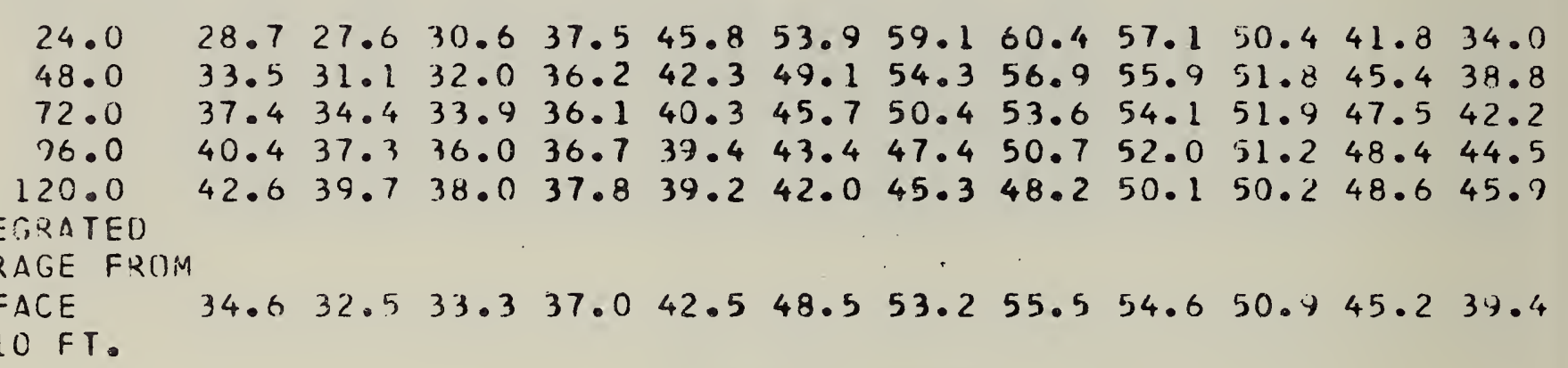

CALCULATED AUGUST EARTH TEMPERATURE AT SELECTED DIFFUSIVITIES
AND SELECTEO DEPTHS

CALCULATED AUGUST EARTH TEMPERATURE AT SELECTED DIFFUSIVITIES
AND SELECTEO DEPTHS

\section{INTESRATED}

AVERAGE FROM

SURFACE
TU $10 \mathrm{FT}$.

UEPTH BELOW

SURFACE(IN)

$$
\begin{array}{r}
24.0 \\
48.0 \\
72.0 \\
96.0 \\
120.0
\end{array}
$$

INTEGRATED

AVERAGE FROM

SURFACE

TO $10 \mathrm{FT}$.

\begin{tabular}{lllll}
\multicolumn{5}{c}{ DIFFUSIVITIES } \\
0.010 & 0.020 & 0.025 & 0.030 & 0.040 \\
58.4 & 60.0 & 60.4 & 60.7 & 61.1 \\
53.1 & 56.1 & 56.4 & 57.5 & 58.4 \\
48.8 & 52.5 & 53.0 & 54.4 & 55.6 \\
45.9 & 49.5 & 50.7 & 51.6 & 53.1 \\
44.1 & 47.1 & 48.2 & 49.2 & 50.8
\end{tabular}

31.9

54.7

53.5

56.1

57.1 
EARTH TEMPERATURE STATION

TYPE CF SOIL

TYPE CF FARTH SURFACE

DATA PROCESSED RY

UATA SOURCE
BOZEMAN, MONTANA

UNKNOWN

UNKNOWN

E. N.FITTON

REFERENCE(4)

PERIDC OF OHSEKVATININ

$1916-1920$

DBSERVEC NOVTHLY AVERAGE EARTH TEMPERATURES

MONTH DF YEAR

DEPTH BELDW

SURFACEIIN)

$\begin{array}{lllllllllllllll}12.0 & 29.7 & 27.1 & 30.2 & 35.0 & 44.2 & 55.4 & 64.4 & 62.9 & 55.4 & 44.6 & 35.4 & 31.5 \\ 24.0 & 31.7 & 30.7 & 31.4 & 34.8 & 42.8 & 52.3 & 60.0 & 61.4 & 56.2 & 47.0 & 38.6 & 34.1 \\ 36.0 & 33.5 & 32.7 & 32.0 & 34.1 & 40.0 & 48.7 & 56.1 & 58.1 & 55.1 & 47.6 & 39.9 & 35.6 \\ 48.0 & 36.0 & 34.1 & 33.6 & 34.6 & 38.8 & 46.1 & 53.8 & 57.3 & 55.2 & 49.2 & 42.8 & 38.3 \\ 60.0 & 37.7 & 35.7 & 34.7 & 35.3 & 38.8 & 44.8 & 51.0 & 54.2 & 53.7 & 49.8 & 44.4 & 40.2 \\ 90.0 & 41.2 & 39.3 & 37.9 & 37.4 & 38.7 & 42.0 & 46.6 & 50.8 & 51.9 & 50.0 & 46.4 & 43.4 \\ 120.0 & 41.8 & 37.8 & 38.5 & 37.9 & 38.7 & 41.7 & 46.1 & 50.0 & 51.4 & 50.1 & 46.9 & 43.7\end{array}$

DEP TH BELOW

RESLLTS OF LEAST SQUARES ANALYSIS

SURF $\triangle C E(I N)$ AVERAGF(A)

$\begin{array}{ll}12.0 & 43.2 \\ 24.0 & 43.5 \\ 36.0 & 42.8 \\ 48.0 & 43.4 \\ 00.0 & 43.4 \\ 30.0 & 43.8 \\ 120.0 & 43.9\end{array}$

AMPLI TUDE (B)

$17 \cdot 6$
$15 \cdot 4$
$13 \cdot 1$
$11 \cdot 5$
$9 \cdot 7$
$6 \cdot 7$
6.5

PHIASE ANGLE(P)

C. 79

0.92

1.04

1.21

1.33

1.66

1.74
STANDARD DEVIATION

3.2
2.4
2.2
2.1
1.4
1.1
1.0

CalCulatec farth temperatures at obServed CePths(*)

UEPTH BELOW

SURFACE(I'V)

MONTH OF YEAR

$12.0 \quad 26.8 \quad 26.4 \quad 30.4 \quad 38$.

$\begin{array}{llllllllllllll}36.0 & 33.1 & 30.8 & 31.8 & 36.2 & 42.5 & 49.5 & 54.7 & 57.2 & 56.0 & 51.7 & 45.1 & 38.4\end{array}$

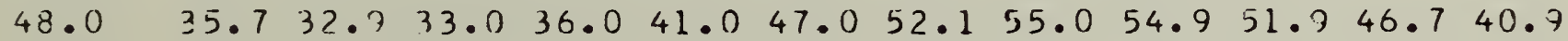

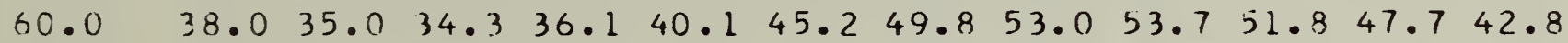

$\begin{array}{lllllllllllllll}70.0 & 42.2 & 39.7 & 37.6 & 37.5 & 39.2 & 42.3 & 45.7 & 48.7 & 50.5 & 50.4 & 48.7 & 45.7\end{array}$

$120.0 \quad 44.5 \quad 42.2 .40 .4 \quad 39.5 \quad 39.8 \quad 41.3 \quad 43.4 \quad 45.8 \quad 47.7 \quad 48.5 \quad 48.2 \quad 46.7$ 
CALCULATEC FARTH TEMPERATURES AT SELECTED CFPTHS

FOR DIFFUSIVITY $=0.025, \quad A=44.0, B O=21.0$ AND $P O=0.63$

DEPTH BELUIN

SURFACE(IN) J J

MONTH OF YEAR

$24.0 \quad 28.4 \quad 27.7 \quad 31.1 \quad 38.2 \quad 46.6 \quad 54.6 \quad 59.5 \quad 60.3 \quad 56.6 \quad 49.6 \quad 41.0 \quad 33.3$

$48.0 \quad 33.1 \quad 31.0 \quad 32.2 \quad 36.7 \quad 43.0 \quad 49.7 \quad 54.7 \quad 57.0 \quad 55.6 \quad 51.2 \quad 44.7 \quad 38.2$

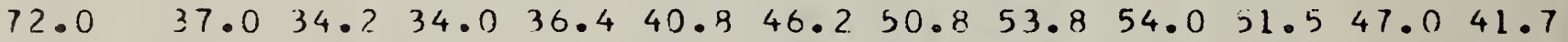

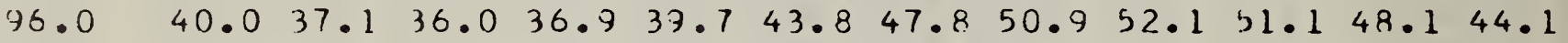

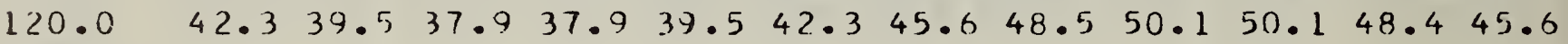
INTEGRATEL:

AVERAGE FRON

SURFACE $\quad 34.3 \quad 32.4 \quad 33.5 \quad 37.5 \quad 43.1 \quad 43.1 \quad 53.5 \quad 55.5 \quad 54.3 \quad 50.4 \quad 44.6 \quad 38.8$ TL $10 \mathrm{FT}$.

CALCULATFD AUgust EARTH TEMPERATURE AT SELECTED DIFFUSIVITIFS AND SELECTEM DEPTHS

DEPTH BELOW

SURFACE (IN)

INTEGQATEO

24.0
48.0
72.0
36.0
120.0
$T E O$
FROM

SURFACE

TI $10 \mathrm{FT}$.
CIFFUSIVITIFS

$\begin{array}{lllll}0.010 & 0.020 & 0.025 & 0.030 & 0.040 \\ 58.4 & 59.9 & 60.3 & 60.6 & 61.0 \\ 53.3 & 56.2 & 57.0 & 57.6 & 58.4 \\ 49.0 & 52.7 & 53.8 & 54.6 & 55.8 \\ 46.1 & 49.7 & 50.9 & 51.8 & 53.3 \\ 44.3 & 47.3 & 48.5 & 49.5 & 51.0\end{array}$

$52 \cdot 1$

54.7

55.5

56.2

57.1 
EARTH TENPERATURE STATION

TYPE CF SOIL

TYPF CF FARTH SURFACE

DATA PROCESSED RY

CIATA SOURCE

PFRICL OF OBSERVATION
HUNTLEY, MGNTANA

$S T-36$

SOD

CLIMATOLOGICAL DATA

$19 t 1-1962$

DBSERVED MONTHLY AVERACE EARTH TEMPERATURES

MCNTH IJF YEAR

DEPTH BFLUW

SURTACE (IN)

$\begin{array}{rllllllllllll}2.0 & 27.8 & 32.0 & 37.8 & 48.6 & 59.8 & 71.4 & 75.1 & 71.9 & 58.1 & 48.6 & 37.5 & 30.3 \\ 4.0 & 26.7 & 30.2 & 36.0 & 47.8 & 58.5 & 70.1 & 74.1 & 71.1 & 58.7 & 48.6 & 37.3 & 30.5 \\ 8.0 & 28.1 & 30.7 & 34.3 & 44.6 & 54.8 & 65.1 & 70.7 & 69.3 & 57.9 & 48.1 & 38.2 & 34.3 \\ 20.0 & 33.5 & 33.7 & 37.3 & 44.6 & 53.7 & 63.7 & 71.6 & 70.5 & 61.8 & 52.5 & 43.0 & 36.4 \\ 40.0 & 37.4 & 36.9 & 38.3 & 42.1 & 49.9 & 57.2 & 65.9 & 63.6 & 60.7 & 56.0 & 48.3 & 42.3 \\ 60.0 & 39.9 & 38.4 & 38.9 & 41.0 & 47.2 & 53.5 & 60.4 & 64.6 & 63.7 & 59.7 & 55.7 & 48.1\end{array}$

RESLLTS IIF LEAST SQUARES ANALYSIS

DEPTH BELOW

SURFACE(II) AVERAGE(A)

$\begin{array}{rl}2.0 & 49.9 \\ 4.0 & 49.2 \\ 8.0 & 48.1 \\ 20.0 & 50.1 \\ 40.0 & 49.9 \\ 60.0 & 51.1\end{array}$

AMPLITUDF(B) PHASE $\triangle N G L E(P)$

$$
\begin{aligned}
& C .50 \\
& 0.53 \\
& C .62 \\
& 0.73 \\
& C .99 \\
& 1.32
\end{aligned}
$$

STANDARD DEVIATION
$3 \cdot 1$
3.0
3.0
2.2
$2 \cdot 1$

$4 \cdot 1$

CALCULATEE FARTH TEMPERATURES AT OBSERVED DEPTHS(*)

UEPTH BELOW

SURFACE(IN)

MOVTH OF YFAR

$\begin{array}{rllllllllllll}2.0 & 25.6 & 29.3 & 38.0 & 50.5 & 62.5 & 71.4 & 74.4 & 70.9 & 61.5 & 49.3 & 37.0 & 28.5 \\ 4.0 & 26.1 & 29.4 & 37.8 & 49.7 & 61.7 & 70.7 & 73.9 & 70.7 & 61.7 & 49.9 & 37.7 & 29.2 \\ 8.0 & 27.1 & 29.8 & 37.5 & 48.9 & 60.3 & 69.3 & 72.8 & 70.3 & 62.0 & 50.9 & 39.1 & 30.6 \\ 20.0 & 30.3 & 31.3 & 36.9 & 46.4 & 56.6 & 65.3 & 69.6 & 68.8 & 62.7 & 53.4 & 42.9 & 34.6 \\ 40.0 & 35.2 & 34.2 & 37.1 & 43.7 & 51.8 & 59.6 & 64.7 & 65.9 & 62.6 & 56.2 & 47.8 & 40.3 \\ 60.0 & .99 .5 & 37.3 & 38.3 & 42.5 & 48.6 & 55.2 & 60.3 & 62.7 & 61.6 & 57.4 & 51.1 & 44.7\end{array}$

(*) BASIC paRAMETERS used for the calculation

$A=50.0,80=25.0, P C=0.47, D=.020$ 
CALCULATEC FARTH TEMPERATURES AT SELFCTED LEPTHS

FOP DIFFUSIVITY $=0.025, A=50.0, B O=25.0$ AND $P[=0.47$

DEPTH BELIIW

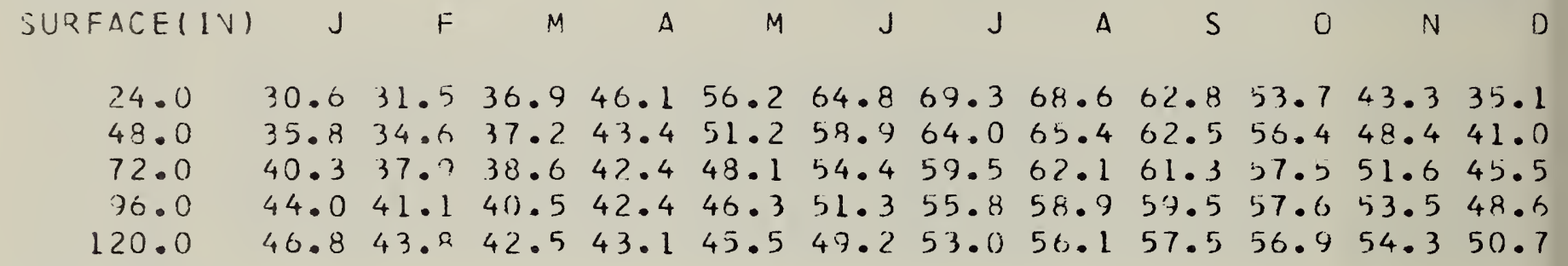

MONTH OF YFAR I VTEGR $\triangle T E D$

AVERAGE FROM

$\begin{array}{lllllllllllllll}\text { SURFACE } & 37.4 & 36.3 & 38.6 & 44.2 & 51.1 & 57.9 & 62.5 & 03.7 & 61.2 & 55.7 & 48.6 & 42.0\end{array}$ TO $10 \mathrm{FT}$.

CALCULATEC nURUSt EARTH temperature at SELECTED DIFFUSIVITIES AND SELECTEN DEPTHS

DEPTHI BELOW

SURFACE(IN)

24.0

48.0

72.0

96.0

120.0

I VTEGRATED

AVERAGE FROM

SURFACE

TO $10 \mathrm{FT}$.

\begin{tabular}{lclll}
\multicolumn{5}{c}{ CIFFUSIVITIES } \\
0.010 & 0.020 & 0.025 & 0.030 & 0.040 \\
66.8 & 68.3 & 68.6 & 68.9 & 69.2 \\
61.5 & 64.6 & 65.4 & 66.0 & 66.8 \\
56.8 & 60.9 & 62.1 & 62.9 & 64.2 \\
53.2 & 57.5 & 58.9 & 59.9 & 61.5 \\
50.9 & 54.7 & 56.1 & 57.3 & 59.0
\end{tabular}

59.8

62.8

63.7

6.4

65.4

D 
FARTH TEMPERATURE STATION

TYPE CF SOIL

TYPE OF FARTH SURFAT,

DATA PROCFSSED BY

UATA SOURCE

PERIOC OF OESERVATION
LINCOLN, INEBRASKA

$S T-37$

UVKNOWN

GARE

E. N.FITTUN

REFERENCE (4)

$1960-1904$

CBSERVED MONTHLY AVERACE EARTH TEMPERATURES

\section{DEPTH BELOW}

SURFACEIIN)

\section{MDNTH UF YEAR}

$\begin{array}{llllllllllllll}1.0 & 30.0 & 28.2 & 42.4 & 58.6 & 74.5 & 82.3 & 90.8 & 85.6 & 72.0 & 60.0 & 43.5 & 31.0\end{array}$

$\begin{array}{llllllllllllllll}3.0 & 30.0 & 28.7 & 41.1 & 59.3 & 72.1 & 81.2 & 88.6 & 85.3 & 72.9 & 61.4 & 44.3 & 31.6\end{array}$

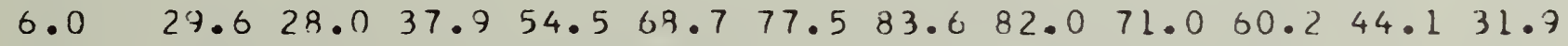

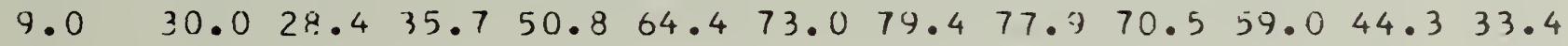

$\begin{array}{llllllllllllll}12.0 & 31.4 & 29.3 & 35.0 & 48.2 & 60.8 & 69.5 & 75.8 & 75.0 & 66.6 & 58.4 & 45.1 & 34.3\end{array}$

$\begin{array}{llllllllllllll}24.0 & 35.1 & 32.9 & 34.7 & 44.8 & 56.5 & 64.2 & 70.8 & 71.6 & 66.9 & 57.7 & 49.5 & 39.5\end{array}$

$\begin{array}{llllllllllllllll}36.0 & 38.1 & 35.3 & 35.7 & 43.0 & 53.2 & 61.1 & 67.5 & 69.4 & 66.7 & 60.7 & 52.1 & 43.2\end{array}$

\section{DEPTH BELOW}

RESLLTS OF LEAST SQUARES ANALYSIS

\section{SURFACE(IN)}

$\begin{array}{rr}1.0 & 58.4 \\ 3.0 & 58.2 \\ 6.0 & 55.9 \\ 9.0 & 54.0 \\ 12.0 & 52.6 \\ 24.0 & 52.3 \\ 36.0 & 52.3\end{array}$

$A V E R \triangle G F(A)$

AMPLITUDE (B)

PHASE ANGLE(P)

C. 53

C.57

0.62

C. 68

0.73

C.89

1.03
STANDARD

DEVIATION
2.0
1.9
1. 5
1. 2
1. 2
1.0
0.8 
CALCULATEC FARTH TEMPERATURES AT SELECTED LEPTHS FOR DIFFUSIVITY $=0.025, A=54.0, B O=28.0$ AND $P O=0.52$

\section{UEPTH BELDW} SURFACE (IN)

\section{MONTH OF YEAR}

$$
\begin{aligned}
& \begin{array}{lllllllllllllll}
24.0 & 32.5 & 32.9 & 38.5 & 48.6 & 59.9 & 69.8 & 75.3 & 75.2 & 69.1 & 59.2 & 47.6 & 38.0
\end{array} \\
& \begin{array}{llllllllllllll}
48.0 & 38.5 & 36.7 & 39.2 & 45.9 & 54.5 & 63.3 & 69.3 & 71.3 & 68.5 & 62.0 & 53.0 & 44.6
\end{array} \\
& \begin{array}{llllllllllllll}
72.0 & 43.6 & 40.6 & 41.0 & 44.9 & 51.2 & 58.3 & 64.2 & 67.4 & 66.9 & 63.0 & 56.5 & 49.5
\end{array} \\
& 96.0447 .744 . ? \quad 43.3 \quad 45.2 \quad 49.3 \quad 54.960 .163 .7 \quad 64.7 \quad 62.8 \quad 58.4 \quad 53.0 \\
& 120.0 \quad 50.8 \quad 47.4 \quad 45.7 \quad 46.1 \quad 48.6 \quad 52.7 \quad 57.0 \quad 60.6 \quad 62.4 \quad 61.959 .2 \quad 55.2
\end{aligned}
$$

I UTEGRATED

AVERAGE FROM

$\begin{array}{lllllllllllllllll}\text { SURFACE } & 40.2 & 38.5 & 40.8 & 46.8 & 54.4 & 62.2 & 67.6 & 69.4 & 66.9 & 61.1 & 53.2 & 45.7\end{array}$ TO $10 \mathrm{FT}$.

CALCULATEC AUGUST EARTH TFMPERATURE AT SELECTED DIFFUSIVITIES AND SELECTEN DEPTHS

OEPTH BELOW

SURFACE (IN)

24.0

48.0

72.0

96.0

120.0

INTEGRATED

AVERAGE FROM

SURFACE

TC $10 \mathrm{FT}$.

$$
\text { CIFFUSIVITIES }
$$

$\begin{array}{lllll}0.010 & 0.020 & 0.025 & 0.030 & 0.040\end{array}$

73.0

66.8

74.7

70.4

61.3

66.0

57.4

54.8

62.2

ง9. 0

75.2

71.3

75.5

75.9

67.4

63.7

60.6

72.0

73.0

(8. 4

69.8

65.0

61.9

66.8

63.9

65.0

68.4

69.4

70.2

71.3 
EARTH TEMPERATURE STATION

TYPE CF SOIL

TYPE OF EARTH SURFACE

DATA PROCESSED BY

DATA SOURCE

PERIDD OF OBSERVATION
LINCOLN, NEBRASKA

$S T-38$

UNKNOWN

UNKNOWN

E. N.FITTON

REFERENCE (4)

$1854-1904$

DBSERVED MONTHLY AVERAGE EARTH TEMPERATURES

\section{DEPTH BELOW}

SURFACE (IN)
MONTH OF YEAR

$\begin{array}{rllllllllllll}1.0 & 28.2 & 28.0 & 40.1 & 58.7 & 70.9 & 79.2 & 86.9 & 85.1 & 73.7 & 58.1 & 40.6 & 31.2 \\ 3.0 & 38.5 & 27.8 & 38.8 & 57.6 & 69.7 & 78.1 & 85.1 & 84.0 & 73.5 & 59.4 & 42.7 & 31.4 \\ 6.0 & 29.0 & 28.1 & 37.4 & 53.6 & 66.7 & 76.1 & 82.1 & 80.9 & 72.0 & 58.3 & 42.6 & 31.7 \\ 9.0 & 29.8 & 28.0 & 36.0 & 50.8 & 64.2 & 73.7 & 79.7 & 78.9 & 71.0 & 58.5 & 38.9 & 28.8 \\ 12.0 & 30.2 & 29.9 & 35.6 & 49.1 & 61.2 & 69.7 & 75.8 & 75.6 & 69.2 & 57.9 & 44.5 & 34.6 \\ 24.0 & 35.1 & 33.1 & 35.3 & 45.4 & 56.9 & 64.6 & 70.5 & 72.0 & 68.2 & 60.0 & 49.2 & 39.5 \\ 36.0 & 38.1 & 35.1 & 36.0 & 43.6 & 53.8 & 61.5 & 67.7 & 69.8 & 67.9 & 61.3 & 51.9 & 43.0\end{array}$

DEPTH BELOW

RESULTS OF LEAST SQUARES ANALYSIS SURFACE ( IN)

AVERAGE (A)

$56 \cdot 9$
$57 \cdot 3$
55.0
53.3
52.9
52.6
52.6

1.0

3.0

6.0

9.0

12.0

24.0

36.0

AMPLITUDEIB
$\begin{array}{r}30.3 \\ 27.8 \\ 27.9 \\ 27.3 \\ 23.9 \\ 19.9 \\ 17.7\end{array}$

STANDARD DEVIATION

0.55
0.60
1.62
0.63
0.72
0.89
1.03

2.0

3.9

1.2

2.2

0.9

0.9

0.7 
CALCULATEC EARTH TEMPERATURES AT SELECTED LEPTHS

FOR DIFFUSIVITY $=0.025, \quad A=53.0, B O=28.0$ AND $P O=0.52$

DEPTH BELOW

SURFACE (IN)

MONTH OF YEAR

\begin{tabular}{|c|c|c|c|c|c|c|c|c|c|c|c|c|}
\hline SURFACE (IN) & J & $F$ & M & $A$ & $M$ & J & J & A & $S$ & 0 & $N$ & D \\
\hline 24.0 & 31.5 & 31.9 & 37.5 & 47.6 & 58.9 & 68.8 & 74.3 & 74.2 & 68.1 & 58.2 & 46.6 & 37.0 \\
\hline 48.0 & 37.5 & 35.7 & $38 \cdot 2$ & $44 \cdot 3$ & 53.5 & 62.3 & 68.3 & 70.3 & & 61.0 & 52.0 & 43.6 \\
\hline 72.0 & & 39.6 & 40.0 & & 50.2 & & 63.2 & 66.4 & & 62.0 & 55.5 & +8.5 \\
\hline 96.0 & 46.7 & 43.2 & 42.3 & $44 \cdot 2$ & $48 \cdot 3$ & 53.9 & 59.1 & 62.7 & 63.7 & 61.8 & 57.4 & 52.0 \\
\hline 120.0 & 49.8 & 46.4 & 44.7 & 45.1 & 47.6 & 51.7 & 56.0 & 59.6 & 61.4 & 60.9 & 58.2 & 54. \\
\hline
\end{tabular}
INTEGRATED

AVERAGE FROM

$\begin{array}{llllllllllllll}\text { SURFACE } & 39.2 & 37.6 & 39.8 & 45.8 & 53.4 & 61.2 & 66.6 & 68.4 & 65.9 & 60.1 & 52.2 & 44.7 \\ \text { TO } 10 \mathrm{FT} . & & & & & & & \end{array}$

CALCULATEC AUGUST EARTH TEMPERATURE AT SELECTED DIFFUSIVITIES AND SELECTED DEPTHS

DEPTH BELOW

SURFACEIIN)

INTECRATED

24.0

48.0

72.0

96.0

120.0

AVERAGE FRDM

SURFACE

TU $10 \mathrm{FT}$.

\section{DIFFUSIVITIES}

$\begin{array}{lllll}0.010 & 0.020 & 0.025 & 0.030 & 0.040\end{array}$

72.0

73.7

$74 \cdot 2$

74.5

74.9

69.4

65.0

61.2

58.0

70.3

66.4

62.7

59.6

71.0

67.4

64.0

60.9

72.0

68.8

65.8

62.9

64.0

67.4

68.4

69.2

70.3 
EARTH TEMPERATURE STATION

TYPE CF SOIL

TYPE CF EARTH SURFACE

DATA PROCESSED BY

DATA SOURCE

PERIOD OF OBSERVATION
NORFOLK, NEBRASKA

$S T-39$

UNKNOWN

UNKNOWN

JEA-HU-CHANG

REFERENCE (5)

$1950-1952$

UBSERVED NONTHLY AVERAGE EARTH TEMPERATURES

\section{DEPTH BELOW}

SURFACE (IN)

\section{MONTH OF YEAR}

$\begin{array}{lllllllll}63.0 & 71.6 & 78.0 & 71.9 & 65.0 & 55.6 & 37.7 & 34.0\end{array}$ $\begin{array}{lllllllll}63.2 & 72.6 & 79.0 & 73.0 & 67.7 & 56.8 & 40.6 & 33.7\end{array}$ $\begin{array}{lllllllll}62.2 & 71.5 & 76.7 & 73.8 & 68.1 & 57.6 & 41.7 & 33.8\end{array}$

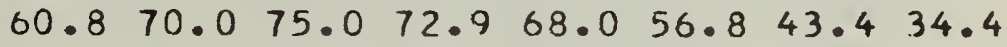
$\begin{array}{lllllllll}57.8 & 66.8 & 72.5 & 71.6 & 67.7 & 59.0 & 47.6 & 38.2\end{array}$

RESLLTS OF LEAST SQUARES ANALYSIS DEPTH BELOW SURFACE (IN)

AVERAGF (A)

52.4

53.5

52.9

52.3

52.5
AMPLITUDE (B)
23.5
23.5
23.7
23.0
20.6

STANDARD DEVIATION
c. 57
0.60
C. 67
0.70
C. 83

2.3

2.5

2.5

2.5

1.5 
CALCULATEC FARTH TEMPERATURES AT SELECTED CEPTHS

FOR DIFFUSIVITY $=0.025, A=53.0, B O=24 . C$ AND $P O=0.54$

UEPTH BELOW

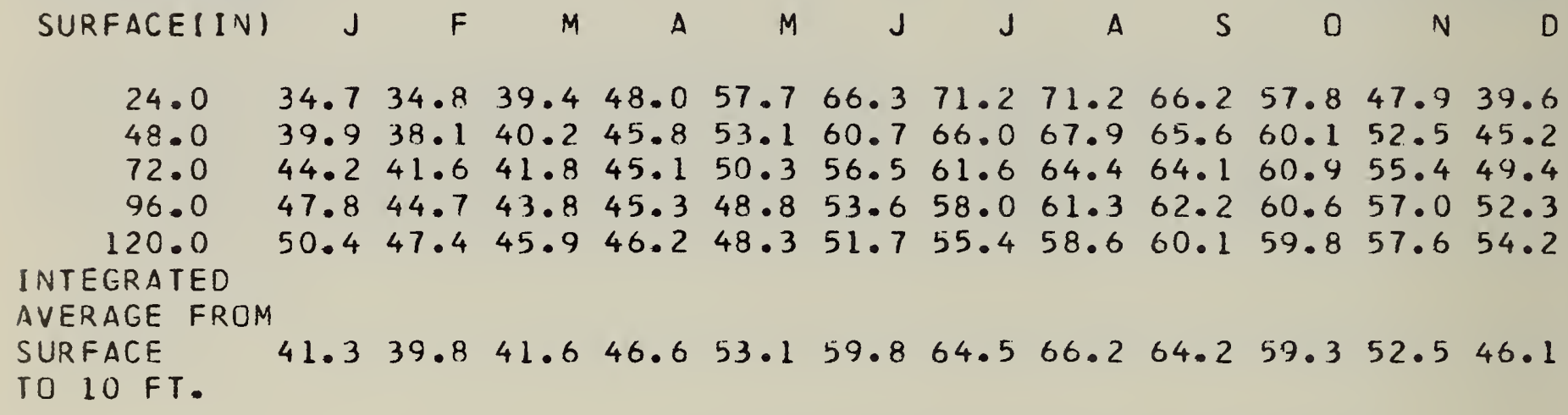

MONTH OF YEAR

CALCULATED ALGUST EARTH TEMPERATURE AT SELECTED OIFFUSIVITIES AND SELECTED DEPTHS

OEPTH BELOW

SURFACE(IN)

24.0

48.0

72.0

96.0

120.0

INTEGRATED

AVERAGE FPOM

SURFACE

TU $10 \mathrm{FT}$.

\begin{tabular}{lllll}
\multicolumn{5}{c}{ DIFFUSIVITIES } \\
0.010 & 0.020 & 0.025 & 0.030 & 0.040 \\
& & & & \\
69.3 & 70.9 & 71.2 & 71.5 & 71.9 \\
63.9 & 67.0 & 67.9 & 68.5 & 69.3 \\
59.2 & 63.3 & 64.4 & 65.3 & 66.6 \\
55.8 & 59.9 & 61.3 & 62.3 & 63.9 \\
53.6 & 57.2 & 58.6 & 59.7 & 61.4
\end{tabular}

62.4

65.3

66.2

66.9

67.9 
EARTH TEMPERATURE STATION

TYPE CF SOIL

TYPE CF EARTH SURFACE

DATA PROCESSED BY

DATA SOURCE

PERIOL OF OBSERVATION
NEW BRUNSWICK, N.J. UNKNOWN

BLUE GRASS SUD

JEN-HU-CHANG

REFERENCE (5)

$1953-1955$

OBSERVED MONTHLY AVERAGE EARTH TEMPERATURES

DEPTH BELOW

SURFACE (IN)
MONTH OF YEAR

$\begin{array}{rllllllllllll}1.0 & 32.9 & 34.9 & 39.3 & 50.4 & 62.0 & 69.6 & 78.7 & 75.2 & 67.6 & 59.7 & 45.9 & 35.9 \\ 3.0 & 33.6 & 35.0 & 39.7 & 49.9 & 57.6 & 67.9 & 73.9 & 72.0 & 66.7 & 60.2 & 46.7 & 38.2 \\ 10.0 & 35.2 & 35.3 & 39.9 & 48.9 & 56.5 & 65.6 & 71.7 & 71.3 & 66.8 & 60.4 & 48.2 & 39.8 \\ 24.0 & 37.8 & 36.4 & 40.1 & 47.0 & 54.4 & 62.6 & 68.3 & 69.8 & 66.4 & 61.4 & 50.8 & 42.8\end{array}$

\section{DEPTH BELOW}

RESLLTS OF LEAST SQUARES ANALYSIS SURFACE (IN)

\begin{abstract}
1.0
3.0

10.0

24.0
\end{abstract}

AVERAGE (A)

$$
\begin{aligned}
& 54.5 \\
& 53.6 \\
& 53.4 \\
& 53.2
\end{aligned}
$$

AMPLITUDE ( B)

$$
\begin{aligned}
& 22.3 \\
& 20.0 \\
& 18.7 \\
& 16.7
\end{aligned}
$$

PHASE ANGLE(P)

$$
\begin{aligned}
& C .69 \\
& 0.75 \\
& C .81 \\
& 0.94
\end{aligned}
$$

ST ANDARD

DEVIATION

1.4
1.1
0.8
0.6 
CALCULATED EARTH TEMPERATURES AT SELECTED DEPTHS FOR DIFFUSIVITY $=0.025, A=53.0, B O=21 . \mathrm{C}$ AND $P O=0.69$

\section{DEPTH BELOW}

SURFACE (IN)

\section{MONTH OF YEAR}

$$
\begin{array}{rllllllllllll}
24.0 & 37.8 & 36.6 & 39.5 & 46.3 & 54.6 & 62.8 & 68.1 & 69.4 & 66.2 & 59.6 & 50.9 & 43.1 \\
48.0 & 42.5 & 40.1 & 40.9 & 45.1 & 51.2 & 58.0 & 63.3 & 65.9 & 64.9 & 60.9 & 54.5 & 47.9 \\
72.0 & 46.4 & 43.4 & 42.9 & 45.0 & 49.2 & 54.6 & 59.4 & 62.6 & 63.1 & 60.9 & 56.6 & 51.3 \\
96.0 & 49.5 & 46.3 & 45.0 & 45.7 & 48.3 & 52.3 & 56.4 & 59.6 & 61.0 & 60.3 & 57.5 & 53.6 \\
120.0 & 51.6 & 48.9 & 47.0 & 46.8 & 48.2 & 51.0 & 54.2 & 57.2 & 59.0 & 59.2 & 57.7 & 55.0
\end{array}
$$
INTEGRATED AVERAGE FROM SURFACE $\begin{array}{llllllllllll}43.7 & 41.5 & 42.3 & 45.9 & 51.4 & 57.4 & 62.1 & 64.5 & 63.6 & 60.0 & 54.3 & 48.5\end{array}$ TO $10 \mathrm{FT}$.

CALCULATED AUGUST EARTH TEMPERATURE AT SELECTED DIFFUSIVITIES AND SELECTEN DEPTHS

DEPTH BELOW SURFACE (IN)

24.0

48.0

72.0

96.0

120.0

INTEGRATED

AVERAGE FROM

SURFACE

TO $10 \mathrm{FT}$.

\section{DIFFUSIVITIES}

$\begin{array}{lllll}0.010 & 0.020 & 0.025 & 0.030 & 0.040 \\ 67.4 & 69.0 & 69.4 & t 9.7 & 70.1 \\ 62.0 & 65.1 & 65.9 & 66.5 & 67.4 \\ 57.8 & 61.5 & 62.6 & 63.4 & 64.6 \\ 54.8 & 58.4 & 59.0 & 60.6 & 62.0 \\ 53.1 & 56.0 & 57.2 & 58.2 & 59.7\end{array}$

60.9

63.6

$64 . j$

65.1

$66 \cdot 1$ 
EARTH TEMPERATURE STATIUN

TYPE CF SOIL

TYPE CF EARTH SURFACE

DATA PROCESSED BY

DATA SOURCE

PERIOC OF OBSERVATION
I THACA, NEW YORK

$S T-41$
GRASS SOD

JEN-HU-CHANG

REFERENCE (5)

$1941-1946$

OBSERVED NONTHLY AVERAGE EARTH TEMPERATURES

\section{DEPTH BELOW}

SURFACE (IN)

$$
\text { MONTH OF YEAR }
$$

$\begin{array}{llllllllllllllll}3.0 & 32.4 & 31.4 & 35.7 & 43.8 & 54.6 & 62.9 & 67.6 & 66.3 & 63.0 & 51.3 & 41.1 & 33.8\end{array}$

$\begin{array}{llllllllllllll}6.0 & 32.8 & 31.8 & 35.5 & 43.3 & 53.6 & 62.2 & 67.1 & 66.2 & 63.3 & 52.0 & 42.0 & 34.4\end{array}$

$\begin{array}{llllllllllllll}12.0 & 33.9 & 32.7 & 35.2 & 42.5 & 52.1 & 60.6 & 65.8 & 65.6 & 63.1 & 53.4 & 43.5 & 36.1\end{array}$

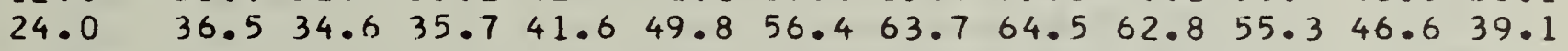

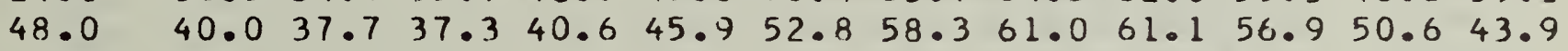

$96.0 \quad 45.7 \quad 43.0 \quad 41.1 \quad 41.6 \quad 53.8 \quad 47.5 \quad 51.4 \quad 54.5 \quad 56.756 .153 .249 .3$

RESLLTS OF LEAST SQUARES ANALYSIS

DEPTH BELOW

SURFACE (IN)
AVERAGE (A)

$$
\begin{aligned}
& 48.8 \\
& 48.8 \\
& 48.8 \\
& 49.0 \\
& 48.9 \\
& 49.5
\end{aligned}
$$

$\triangle M P L I T U D E(B)$

PHASE ANGLE(P)

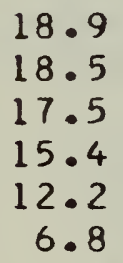

STANDARD

DEVIATION

$$
\begin{aligned}
& C .71 \\
& 0.75 \\
& C .83 \\
& 0.97 \\
& 1.23 \\
& 1.51
\end{aligned}
$$

$1 \cdot 3$

1.2

1.1

1.1

0.6

2.9 
CALCULATEC EARTH TEMPERATURES AT SELECTED CEPTHS

FOR DIFFUSIVITY $=0.025, \quad A=49.0, B O=19.0$ AND $P O=0.69$

DEPTH BELOW MONTH OF YEAR

SURFACE(IN)

$\begin{array}{lllllllllllll}24.0 & 35.2 & 34.2 & 36.8 & 42.9 & 50.5 & 57.8 & 62.6 & 63.9 & 60.9 & 54.9 & 47.1 & 40.1 \\ 48.0 & 39.5 & 37.3 & 38.1 & 41.8 & 47.4 & 53.5 & 58.3 & 60.7 & 59.8 & 56.1 & 50.3 & 44.4 \\ 72.0 & 43.1 & 40.3 & 39.8 & 41.8 & 45.6 & 50.4 & 54.8 & 57.6 & 58.1 & 56.2 & 52.2 & 47.5 \\ 96.0 & 45.8 & 43.0 & 41.7 & 42.4 & 44.8 & 48.4 & 52.0 & 55.0 & 56.3 & 55.6 & 53.1 & 49.6 \\ 120.0 & 47.8 & 45.2 & 43.6 & 43.4 & 44.7 & 47.2 & 50.1 & 52.8 & 54.5 & 54.6 & 53.2 & 50.8\end{array}$
INTEGRATED

AVERAGE FROM

SURFACE $\quad 40.6 \quad 38.6 \quad 39.3 \quad 42.6 \quad 47.5 \quad 53.0 \quad 57.3 \quad 59.4 \quad 58.6 \quad 55.3 \quad 50.2 \quad 44.9$ TO 10 FT.

CALCULATED AUGUST EARTH TEMPERATURE AT SELECTED DIFFUSIVITIES AND SELECTED DEPTHS

DEPTH BELOW

SURFACE (IN)

$$
\begin{array}{r}
24 \cdot 0 \\
48 \cdot 0 \\
72 \cdot 0 \\
96 \cdot 0 \\
120 \cdot 0
\end{array}
$$

I NTEGRATED

AVERAGE FROM

SURFACE

TO $10 \mathrm{FT}$.

\begin{tabular}{lclll}
\multicolumn{5}{c}{ DIFFUSIVITIES } \\
0.010 & 0.020 & 0.025 & 0.030 & 0.040 \\
& & & & \\
62.0 & 63.5 & 63.9 & 64.1 & 64.5 \\
57.2 & 59.9 & 60.7 & 61.2 & 62.0 \\
53.3 & 56.7 & 57.6 & 58.4 & 59.5 \\
50.7 & 53.9 & 55.0 & 55.9 & 57.2 \\
49.1 & 51.7 & 52.8 & 53.7 & 55.1
\end{tabular}

56.2

$58 \cdot 6$

59.4

60.0

60.8 
EARTH TEMPERATURE STATION

TYPE CF SUIL

TYPE OF EARTH SURFACE

DATA PROCESSED BY

DATA SOURCE

PERIOC OF OESERVATION
ITHACA, NEW YORK

$S T-42$
LOAM

GRASS-SOD

US WEATHER R.C.

1943-1947

OBSERVED MONTHLY AVERAGE EARTH TEMPERATURES

DEPTH BELOW

SURFACE (IN)

$\begin{array}{rrrrrrrrrrrrr} \\ 0 . & 31.6 & 31.2 & 36.0 & 43.6 & 54.2 & 65.0 & 69.0 & 66.4 & 57.8 & 49.8 & 39.2 & 33.4 \\ 3.0 & 32.2 & 31.8 & 35.0 & 42.8 & 52.8 & 63.8 & 68.6 & 66.0 & 58.4 & 50.6 & 40.4 & 34.4 \\ 6.0 & 32.8 & 32.2 & 35.2 & 41.4 & 52.4 & 63.4 & 67.4 & 66.0 & 58.8 & 51.2 & 41.2 & 35.2 \\ 12.0 & 33.8 & 33.2 & 35.2 & 41.6 & 51.2 & 61.4 & 66.2 & 64.0 & 59.0 & 51.0 & 44.0 & 37.2 \\ 24.0 & 36.6 & 35.2 & 35.6 & 41.2 & 48.8 & 59.0 & 64.2 & 64.2 & 00.2 & 54.4 & 47.6 & 40.0 \\ 48.0 & 40.2 & 38.4 & 37.4 & 40.6 & 45.2 & 52.0 & 59.2 & 61.0 & 59.8 & 55.8 & 51.0 & 45.4 \\ 96.0 & 46.0 & 43.2 & 41.4 & 41.6 & 43.8 & 48.2 & 52.6 & 55.4 & 56.8 & 55.8 & 52.7 & 49.2\end{array}$

DEPTH BELOW

RESLLTS OF LEAST SQUARES ANALYSIS

SURFACE (IN)

$\begin{array}{rl}0.0 & 48.2 \\ 3.0 & 48.2 \\ 6.0 & 48.2 \\ 12.0 & 48.3 \\ 24.0 & 49.0 \\ 48.0 & 48.9 \\ 96.0 & 49.0\end{array}$

MONTH OF YEAR
STANDARD DEVIATION

$3 \cdot 1$
$3 \cdot 1$
$3 \cdot 0$
$2 \cdot 6$
$2 \cdot 7$
$2 \cdot 6$
1.2

\title{
CALCULATED EARTH TEMPERATURES AT OBSERVEO OEPTHS(-)
}

\section{DEPTH BELOW}

SURFACE ( [N]

\author{
MONTH OF YEAR
}

$\begin{array}{rllllllllllll}0 . & 30.1 & 31.6 & 37.3 & 46.6 & 56.2 & 64.1 & 67.8 & 66.5 & 60.3 & 51.3 & 41.4 & 33.8 \\ 3.0 & 30.8 & 31.9 & 37.2 & 46.1 & 55.4 & 63.3 & 67.2 & 66.2 & 60.4 & 51.8 & 42.1 & 34.6 \\ 6.0 & 31.4 & 32.2 & 37.2 & 45.6 & 54.7 & 62.5 & 66.5 & 65.8 & 60.5 & 52.2 & 42.8 & 35.4 \\ 12.0 & 32.7 & 32.9 & 37.1 & 44.8 & 53.4 & 61.0 & 65.2 & 65.1 & 60.6 & 53.1 & 44.2 & 36.9 \\ 24.0 & 35.1 & 34.4 & 37.3 & 43.5 & 51.1 & 58.2 & 62.7 & 63.6 & 60.5 & 54.3 & 46.6 & 39.7 \\ 48.0 & 39.5 & 37.5 & 38.4 & 42.2 & 47.7 & 53.7 & 58.3 & 60.5 & 59.5 & 55.7 & 50.0 & 44.2 \\ 96.0 & 45.9 & 43.2 & 42.0 & 42.7 & 45.0 & 48.5 & 52.0 & 54.8 & 56.0 & 55.3 & 52.9 & 49.5\end{array}$


CALCULATED FARTH TEMPERATURES AT SELECTED CEPTHS

FOR DIFFUSIVITY $=0.025, A=49.0, B D=19 . C$ AND $P O=0.64$

\section{DEPTH BELOW}

\section{MONTH OF YEAR}

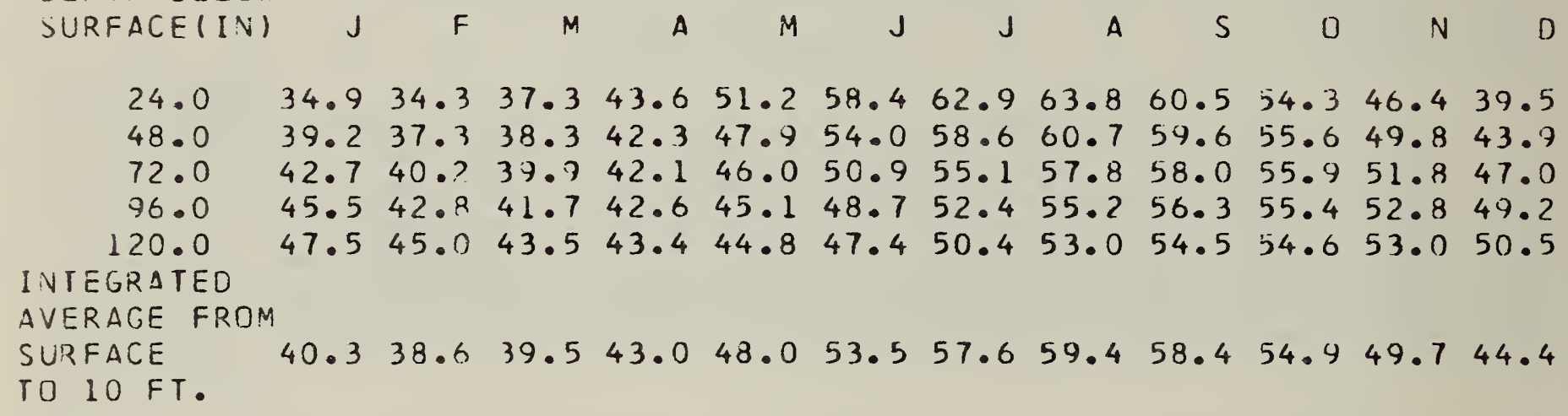
SURFACE (IN)

CALCULATEC AUGUST EARTH TEMPERATURE AT SELECTED UIFFUSIVITIES AND SELECTED DEPTHS

DEPTH BELOW

SURFACE (IN)

24.0
48.0
72.0
96.0
120.0

INTEGRATED

AVERAGE FROM

SURFACE

TO $10 \mathrm{FT}$.

\begin{tabular}{lclll}
\multicolumn{5}{c}{ OIFFUSIVITIES } \\
0.010 & 0.020 & 0.025 & 0.030 & 0.040 \\
& & & & \\
62.0 & 63.4 & 63.8 & 64.0 & 64.4 \\
57.3 & 60.0 & 60.7 & 61.3 & 62.0 \\
53.5 & 56.8 & 57.8 & 58.5 & 59.6 \\
50.8 & 54.1 & 55.2 & 56.1 & 57.3 \\
49.2 & 51.9 & 53.0 & 53.9 & 55.3
\end{tabular}

$56 \cdot 3$

58.7

59.4

60.0

60.8 
EARTH TEMPERATURE STATION

TYPE CF SOIL

TYPE CF. EARTH SURFACE

DATA PROCESSED BY

DATA SOURCE

PERIOC OF TESERVATION
RALEIGH, N.C.

SANUY LDAM

BARE

CLIMATOLOSICAL DATA

$1960-1962$

CBSERVED MONTHLY AVERAGE EARTH TEMPERATURES

$$
\text { MONTH OF YEAR }
$$

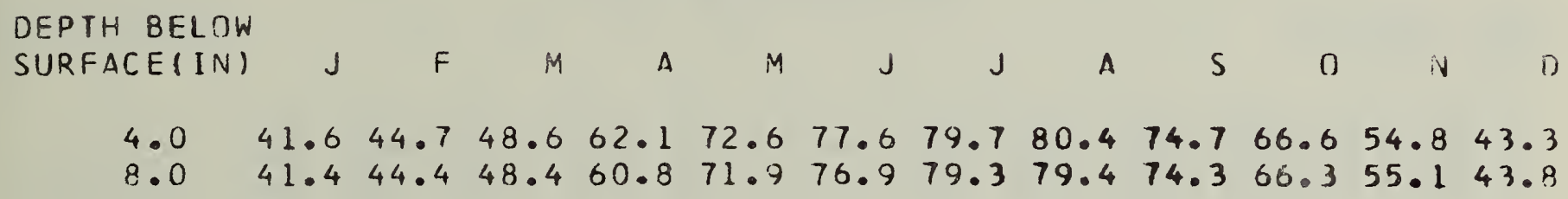

RESLLTS OF LEAST SQUARES ANALYSIS

DEPTH BELCW

SURFACE(IN) AVERAGE (A)

4.0

8.0
62.4

62.0
AMPLITUDE (B)

PHASE ANGLE(P)

20.2

19.8
STANDARI) DEVIATION

3.1

2.9 


\title{
CALCULATEC FARTH TEMPERATURES AT SELECTED CEPTHS
}

FOR DIFFUSIVITY $=0.025, A=62.0, B O=19.0$ AND $P O=0.60$

\section{DEPTH BELOW}

SURFACE(IN)

\section{MONTH OF YEAR}

$$
\begin{array}{r}
24.0 \\
48.0 \\
72.0 \\
96.0 \\
120.0
\end{array}
$$

INTEGRATED

AVERAGE FROM

SURFACE

TO $10 \mathrm{FT}$.

\begin{abstract}
$\begin{array}{lllllllllllll}47.7 & 47.4 & 50.7 & 57.2 & 64.8 & 71.9 & 76.1 & 76.6 & 73.1 & 66.7 & 58.8 & 52.0\end{array}$ $\begin{array}{lllllllllllll}51.9 & 50.2 & 51.5 & 55.7 & 61.4 & 67.5 & 71.9 & 73.8 & 72.3 & 68.2 & 62.3 & 56.4\end{array}$ $\begin{array}{lllllllllllll}55.4 & 53.1 & 53.0 & 55.3 & 57.4 & 64.2 & 68.4 & 70.9 & 71.0 & 68.6 & 64.4 & 59.7\end{array}$ $\begin{array}{llllllllllll}58.2 & 55.6 & 54.7 & 55.7 & 58.3 & 62.0 & 65.6 & 68.3 & 69.3 & 68.3 & 65.5 & 61.9\end{array}$

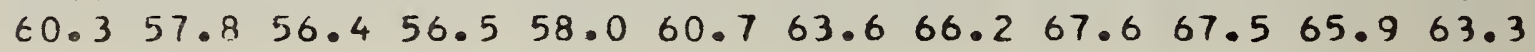

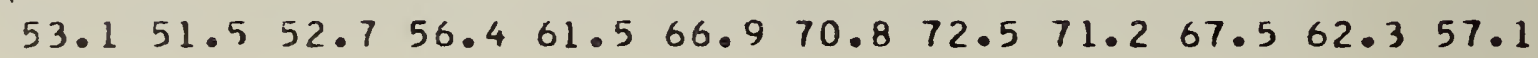

CALCULATED AUGUST EARTH TEMPERATURE AT SELECTED DIFFUSIVITIES AND SELECTED DEPTHS

DEPTH BELOW

SURFACE (IN)

$$
24.0
$$

48.0

72.0

96.0

120.0

INTEGRATEO

AVERAGE FROM

SURFACF.

TO $10 \mathrm{FT}$.

$\begin{array}{ll} & \text { DIFFUSIVITIES } \\ 0.010 & 0.020 \\ 75.0 & 76.3 \\ 70.5 & 73.1 \\ 66.7 & 70.0 \\ 64.0 & 67.3 \\ 62.3 & 65.1\end{array}$

0.025

0.030

0.040

76.6

73.8

70.9

68.3

66.2

76.9

74.3

71.6

69.2

67.1

77.2

75.0

72.7

70.5

68.4

69.3

71.7

72.5

73.0

73.8 
EARTH TEMPERATURE STATION

TYPE CF SOIL

TYPE CF EARTH SURFACE

DATA PROCESSED BY

DATA SOURCE

PERIDO OF OHSERVATIDN
COLUMBUS, OHIO

SILT LOAM

GRASS

CLIMATOLUGICAL UATA

$1960-1962$

OBSERVED MONTHLY AVERAGE EARTH TEMPERATURES

MONTH OF YEAR

\section{DEPTH BELOW}

SURFACEIIN)

$\begin{array}{llllllllllllll}4.0 & 31.0 & 32.2 & 37.2 & 48.2 & 58.8 & 66.4 & 70.9 & 69.9 & 67.1 & 55.6 & 43.9 & 32.8\end{array}$

$\begin{array}{llllllllllllll}8.0 & 34.5 & 34.6 & 38.9 & 48.1 & 59.7 & 69.6 & 72.8 & 72.8 & 69.6 & 56.4 & 46.8 & 34.8\end{array}$

$20.0 \quad 37.5 \quad 36.0 \quad 39.4 \quad 46.6 \quad 56.7 \quad 65.5 \quad 69.4 \quad 70.0 \quad 67.6 \quad 59.7 \quad 49.3 \quad 40.7$ $\begin{array}{lllllllllllll}39.0 & 41.6 & 39.5 & 41.2 & 46.5 & 54.7 & 61.9 & 66.7 & 68.1 & 67.2 & 60.8 & 53.2 & 45.2\end{array}$

RESLLTS OF LEAST SQUARES ANALYSIS

DEPTH BELOW

SURFACEIIN) AVERAGF(A)

$\begin{array}{rr}4.0 & 51.3 \\ 8.0 & 53.3 \\ 20.0 & 53.3 \\ 39.0 & 54.0\end{array}$

AMPLITUDE (B)

21.0
21.0
17.8
14.7
PHASE ANGLE(P)

0.70
0.72
0.86
1.00
STANDARD

DEVIATION

2.8

2.6

1.8

1.6 
CALCULATEC EARTH TEMPERATURES AT SELECTED [EPTHS

FOR DIFFUSIVITY $=0.023, A=53.0, B O=22.0$ AND $P O=0.65$

\section{DEPTH BELOW} SURFACE(IN)

\section{MONTH OF YEAR}

$\begin{array}{llllllllll}J & F & M & A & M & J & J & A & S & 0\end{array}$

$24.0 \quad 36.8 \quad 35.7 \quad 39.3 \quad 46.6 \quad 55.4 \quad 63.8 \quad 69.1 \quad 70.1 \quad 66.4 \quad 59.2 \quad 50.2 \quad 42.1$

$\begin{array}{llllllllllllllll}48.0 & 41.7 & 39.4 & 40.6 & 45.1 & 51.6 & 58.7 & 64.1 & 66.6 & 65.3 & 60.8 & 54.0 & 47.2\end{array}$

$\begin{array}{llllllllllllll}72.0 & 45.8 & 42.8 & 42.5 & 44.9 & 49.4 & 55.1 & 60.0 & 63.2 & 63.5 & 61.0 & 56.3 & 50.8\end{array}$

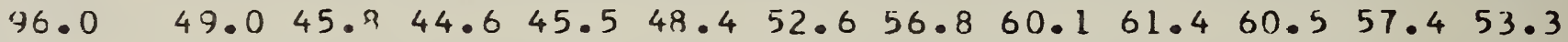

$120.0 \quad 51.3 \quad 48.4 \quad 46.7 \quad 46.5 \quad 48.1 \quad 51.1 \quad 54.5 \quad 57.6 \quad 59.4 \quad 59.4 \quad 57.7 \quad 54.8$

INTEGRATED

AVERAGE FROM

SURFACE

$\begin{array}{llllllllllll}43.0 & 40.7 & 41.9 & 46.0 & 51.8 & 58.1 & 62.9 & 65.1 & 63.9 & 59.9 & 53.9 & 47.8\end{array}$

TO $10 \mathrm{FT}$.

CALCULATED AUGUST EARTH TEMPERATURE AT SELECTED DIFFUSIVITIES AND SELECTEN DEPTHS

DEPTH BELOW

SURFACE (IN)

$$
\begin{array}{r}
24.0 \\
48.0 \\
72.0 \\
96.0 \\
120.0
\end{array}
$$

INTEGRATED

AVERAGE FROM

SURFATE

TO $10 \mathrm{FT}$.

\begin{tabular}{lllll}
\multicolumn{5}{c}{ DIFFUSIVITIES } \\
0.010 & 0.020 & 0.025 & 0.030 & 0.040 \\
63.1 & 69.7 & 70.1 & 10.4 & 70.8 \\
62.6 & 65.7 & 66.6 & 67.2 & 68.1 \\
58.2 & 62.0 & 63.2 & 64.0 & 65.3 \\
55.1 & 58.9 & 60.1 & 61.1 & 62.6 \\
53.2 & 56.4 & 57.6 & 58.6 & 60.3
\end{tabular}

$61 \cdot 4$

64.2

65.1

65.7

66.7 
EARTH TEMPERATURE STATION

TYPE CF SOIL

TYPE OF EARTH SURFACE

DATA PROCESSED BY

DATA SOURCE

PERIOC OF OESERVATION
COSHOCTON, OHIO

SILT LOAM

ME $10 O W$

JEN-HU-CHANG

REFERENCE (5)

$1942-1955$

\section{OBSERVED MONTHLY AVERAGE EARTH TEMPERATURES}

\section{DEPTH BELOW}

SURFACE (IN)

$$
\text { MONTH OF YEAR }
$$

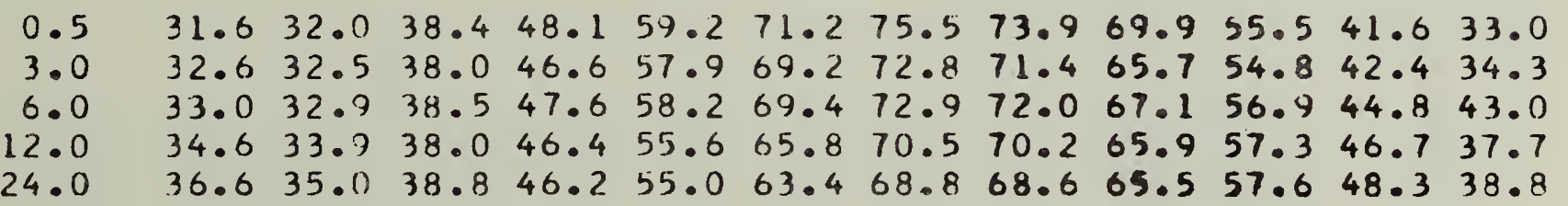

DEPTH BELOW SURFACE (IN)

\section{AVERAGE $(A)$}

52.6

51.6

53.1

52.0

52.0

$\begin{array}{rl}0.5 & 52.6 \\ 3.0 & 51.6 \\ 6.0 & 53.1 \\ 12.0 & 52.0 \\ 24.0 & 52.0\end{array}$

0.5

24.0
STANDARD DEVIATION

$$
\begin{aligned}
& 0.67 \\
& C .68 \\
& 0.76 \\
& C .80 \\
& 0.84
\end{aligned}
$$

1.7

1.2

1.9

0.6

0.7 
CALCULATEC EARTH TEMPERATURES AT SELECTED DEPTHS

FOR DIFFUSIVITY $=0.025, \quad A=52.0, B O=22.0$ AND $P D=0.67$

UEPTH BELOW

SURFACE (IN)

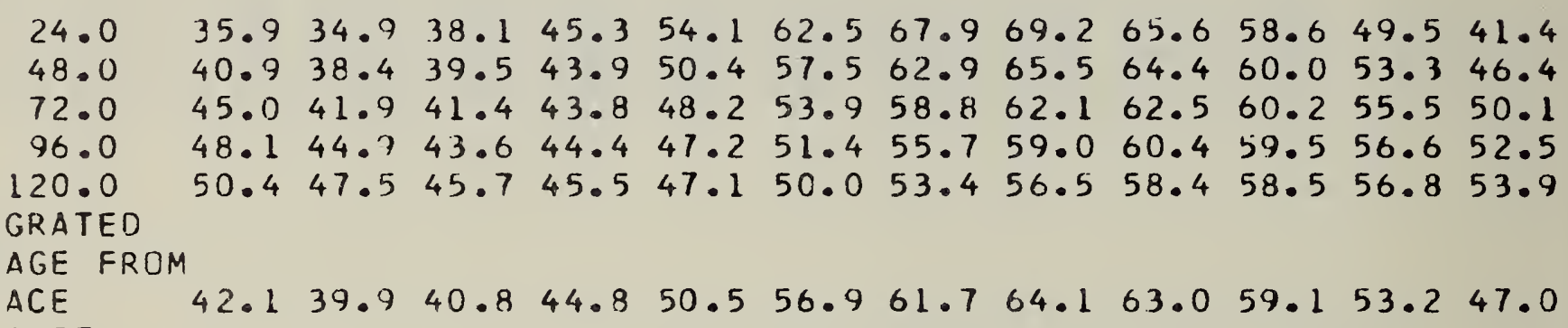

CALCULATED AUGUST EARTH TEMPERATURE AT SELECTED DIFFUSIVITIES AND SELECTEN DEPTHS

DEPTH BELOW

SURFACE (IN)

24.0
48.0
72.0
96.0
20.0

INTEGRATED

120.0

AVERAGE FROM

SURFACE

TO $10 \mathrm{FT}$.

MOVTH OF YEAR

$\begin{array}{rlllll}\text { SURFACE(IN) } & 0.010 & 0.020 & 0.025 & 0.030 & 0.040 \\ 24.0 & 67.1 & 68.7 & 69.2 & 69.5 & 69.9 \\ 48.0 & 61.6 & 64.7 & 65.5 & 66.2 & 67.1 \\ 72.0 & 57.1 & 60.9 & 62.1 & 63.0 & 64.2 \\ 96.0 & 54.0 & 57.8 & 59.0 & 60.0 & 61.6 \\ 120.0 & 52.2 & 55.3 & 56.5 & 57.5 & 59.2 \\ \text { INTEGRATED } & & & & & \\ \text { AVERAGE FROM } & 60.4 & 63.2 & 64.1 & 64.7 & 65.7 \\ \text { SURFACE } & & & & & \end{array}$


EARTH TEMPERATURE STATION

TYPE OF SOIL

TYPE OF EARTH SURFACE

DATA PROCESSED BY

DATA SOURCE

PERIOD OF UESERVATION
BARNSDALL, OKLA.

ST -46

OBSERVED NONTHLY AVERAGE EARTH TEMPERATURES

DEPTH BELOW

MONTH OF YEAR

SURFACE (IN)

3.9

$41.143 .0 \quad 44.8 \quad 54.3 \quad 66$.

A

UNKNOWN

UNKNOWN

JEA-HU-CHANG

REFERENCE ( 5 )

$1950-1952$

$\begin{array}{llllllllllllllll}7.9 & 42.6 & 44.4 & 46.4 & 55.7 & 67.2 & 77.0 & 81.3 & 82.6 & 74.6 & 66.4 & 50.2 & 43.3\end{array}$

$\begin{array}{llllllllllllll}11.8 & 46.1 & 47.4 & 49.6 & 58.7 & 67.8 & 75.6 & 79.2 & 81.7 & 75.0 & 68.6 & 54.8 & 46.4\end{array}$

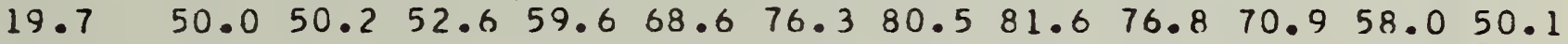

$\begin{array}{lllllllllllllll}39.4 & 52.8 & 52.2 & 53.9 & 58.3 & 66.0 & 73.2 & 75.1 & 81.4 & 78.2 & 74.6 & 63.6 & 55.4\end{array}$

DEPTH BELOW

RESLLTS OF LEAST SQUARES ANALYSIS SURFACE ( [N]
AMPLITUDE (B) PHASE ANGLE(P)
$21 \cdot 3$
20.9
18.3
16.8
14.4

STANDARD

DEVIATION

$$
\begin{aligned}
& 0.68 \\
& 0.70 \\
& 0.73 \\
& C .77 \\
& 1.01
\end{aligned}
$$

2.3

2.1

1.7

1.6

1. 7 
CALCULATEC EARTH TEMPERATURES AT SELECTED CEPTHS

FOR DIFFUSIVITY $=0.025, A=65.0, B D=21.0$ AND $P O=0.65$

MCNTH OF YEAR

DEPTH BELOW

SURFACE (IN)

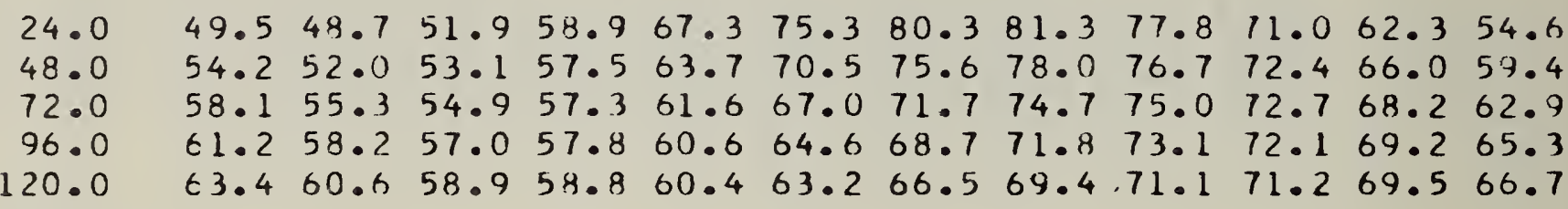
INTEGRATED

AVERAGE FROM

SURFACE

$55.4 \quad 53.5 \quad 54.4 \quad 58.3 \quad 63.8 \quad 69.974 .4 \quad 76.5 \quad 75.471 .6 \quad 65.960 .1$

TO $10 \mathrm{FT}$.

CALCULATED AUGUST EARTH TEMPERATURE AT SELECTED DIFFUSIVITIES AND SELECTED DEPTHS

DEPTH BELOW

SURFACE (IN)

24.0

48.0

72.0

96.0

120.0

INTEGRATED

AVERAGE FRDM

SURFACE

TO $10 \mathrm{FT}$.

\begin{tabular}{lcccc}
\multicolumn{5}{c}{ DIFFUSIVITIES } \\
0.010 & 0.020 & 0.025 & 0.030 & 0.040 \\
79.4 & 80.9 & 81.3 & $\varepsilon 1.6$ & 82.0 \\
74.2 & 77.2 & 78.0 & 78.5 & 79.4 \\
70.0 & 73.6 & 74.1 & 75.5 & 76.7 \\
67.0 & 70.6 & 71.8 & 72.8 & 74.2 \\
65.2 & 68.2 & 69.4 & 70.4 & 71.9
\end{tabular}

73.0

75.7

$76 \cdot 5$

77.2

$78 \cdot 1$ 
EARTH TEMPERATURE STATIUN

TYPE OF SOIL

TYPE OF EARTH SURFACE

DATA PROCESSED BY

DATA SOURCE

PERIOC OF OESERVATION
HOMINY, OKLA.
UNKNOWN

UNKNOWN

JEA-HU-CHANG

REFERENCE (5)

$1950-1952$

OBSERVED NONTHLY AVERAGE EARTH TEMPERATURES

MCNTH OF YEAR

\section{DEPTH BELOW}

SURFACE (IN)
3.9

11.8

19.7

39.4

46.246 .450 .257$.

$A$

S

O N

D $\begin{array}{lllllllllllll}44.4 & 44.7 & 48.7 & 55.8 & 67.5 & 77.9 & 85.1 & 85.4 & 79.4 & 68.6 & 54.3 & 46.8\end{array}$ $\begin{array}{lllllllllllll}45.8 & 46.0 & 49.8 & 56.7 & 67.7 & 76.8 & 83.5 & 83.8 & 78.2 & 68.9 & 55.3 & 48.7\end{array}$ $\begin{array}{lllllllllllll}48.9 & 46.6 & 50.0 & 56.6 & 67.8 & 76.7 & 83.2 & 83.0 & 78.0 & 68.4 & 59.2 & 48.2\end{array}$ $\begin{array}{lllllllllllll}48.4 & 45.7 & 49.1 & 55.9 & 66.0 & 73.8 & 80.1 & 82.1 & 77.1 & 68.2 & 61.6 & 47.3\end{array}$

RESULTS OF LEAST SQUARES ANALYSIS DEPTH BELOW SURFACE(IN)

\section{AMPLITUDE (B)}

$$
\begin{aligned}
& 20.2 \\
& 21.5 \\
& 19.9 \\
& 18.9 \\
& 18.2
\end{aligned}
$$

STANDARD DEVIATION

$$
\begin{aligned}
& 0.78 \\
& 0.77 \\
& 0.78 \\
& C .80 \\
& 0.87
\end{aligned}
$$

1.6

1.8

1. 5

1.7

1.8 


\section{CALCULATEC EARTH TEMPERATURES AT SELECTED CEPTHS}

FOR DIFFUSIVITY $=0.025, A=63.0, B D=21.0$ AND $P O=0.73$

\section{DEPTH BELOW}

SURFACE(IN)

$$
\text { MONTH OF YEAR }
$$

$\begin{array}{lllllllllllll}24.0 & 48.0 & 46.5 & 49.2 & 55.7 & 64.0 & 72.2 & 77.8 & 79.5 & 76.6 & 70.2 & 61.6 & 53.7 \\ 48.0 & 52.8 & 50.7 & 50.7 & 54.7 & 60.7 & 67.5 & 72.9 & 75.8 & 75.1 & 71.3 & 65.0 & 58.4 \\ 72.0 & 56.8 & 53.6 & 52.8 & 54.8 & 58.8 & 64.2 & 69.0 & 72.4 & 73.2 & 71.2 & 66.9 & 61.8 \\ 96.0 & 59.7 & 56.5 & 55.0 & 55.6 & 58.1 & 62.0 & 66.1 & 69.4 & 71.0 & 70.4 & 67.8 & 63.9 \\ 120.0 & 61.9 & 58.9 & 57.1 & 56.7 & 58.0 & 60.7 & 64.0 & 67.0 & 68.9 & 69.3 & 67.9 & 65.2\end{array}$
INTEGRATED AVERAGE FROM SURFACE TO $10 \mathrm{FT}$.

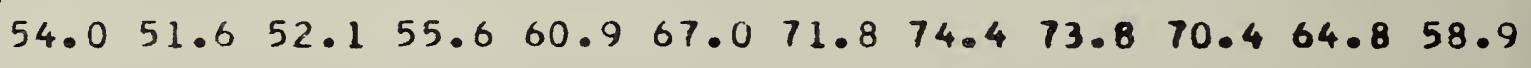

CALCULATED AUGUST EARTH TEMPERATURE AT SELECTED DIFFUSIVITIES AND SELECTED DEPTHS

DEPTH BELOW

SURFACE (IN)

24.0
48.0
72.0
96.0
20.0

INTEGRATED

120

AVERAGE FROM

SURFACE

TO $10 \mathrm{FT}$.

\begin{tabular}{lllll}
\multicolumn{5}{c}{ DIFFUSIVITIES } \\
0.010 & 0.020 & 0.025 & 0.030 & 0.040 \\
77.3 & 79.1 & 79.5 & 79.8 & 80.2 \\
71.9 & 75.0 & 75.8 & 76.5 & 77.3 \\
67.6 & 71.3 & 72.4 & 73.3 & 74.5 \\
64.7 & 68.2 & 69.4 & 70.4 & 71.9 \\
63.0 & 65.8 & 67.0 & 68.0 & 69.6
\end{tabular}

70.8

73.6

$74 \cdot 4$

75.1

76.0 
EARTH TEMPERATURE STATION

TYPE CF SOIL

TYPE OF EARTH SURFACE

DATA PROCESSED BY

DATA SOURCE

PERIOC OF OBSERVATION
LAKE HEFNER, OKLA.

UNKNOWN

UNKNOWN

JEA-HU-CHANG

REFERENCE (5)

$1950-1952$

OBSERVED MONTHLY AVERAGE EARTH TEMPERATURES

DEPTH BELOW

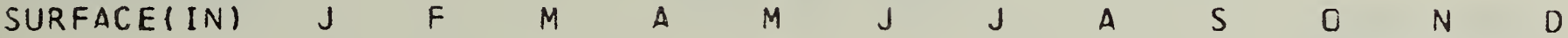

$\begin{array}{llllllllllllllll}3.9 & 39.3 & 41.7 & 49.1 & 58.3 & 72.0 & 81.0 & 81.9 & 83.6 & 75.6 & 70.7 & 51.8 & 41.9\end{array}$

$\begin{array}{llllllllllllll}7.9 & 41.3 & 41.5 & 49.0 & 57.3 & 69.0 & 80.2 & 86.6 & 86.5 & 78.6 & 71.8 & 53.7 & 44.9\end{array}$

$\begin{array}{llllllllllllll}11.8 & 44.7 & 43.5 & 49.8 & 59.4 & 69.8 & 78.8 & 81.8 & 84.5 & 78.1 & 74.6 & 58.6 & 47.9\end{array}$

$\begin{array}{lllllllllllllll}39.4 & 49.1 & 46.7 & 50.5 & 56.5 & 65.8 & 73.2 & 77.8 & 81.0 & 77.4 & 74.3 & 64.6 & 53.3\end{array}$

RESLLTS OF LEAST SQUARES ANALYSIS

DEPTH BELOW

SURFACEIIN)

AVERAGF (A)

$$
\begin{aligned}
& 62.4 \\
& 63.5 \\
& 64.4 \\
& 64.3
\end{aligned}
$$

AMPLITUDE (B)

$$
\begin{aligned}
& 22.9 \\
& 23.5 \\
& 20.7 \\
& 16.9
\end{aligned}
$$

STANDARD

DEVIATION

$$
\begin{aligned}
& 2.4 \\
& 1.7 \\
& 2.0 \\
& 1.3
\end{aligned}
$$




\section{CALCULATED EARTH TEMPERATURES AT SELECTED CEPTHS}

FOR DIFFUSIVITY $=0.025, A=64.0,80=23.0$ AND $P O=0.63$

DEPTH BELOW

SURFACEIIN)

\section{MONTH OF YEAR}

\section{$24.0 \quad 46.9 \quad 46.2 \quad 49.9 \quad 57.7 \quad 66.9 \quad 75.6 \quad 80.9 \quad 81.8 \quad 77.8 \quad 70.2 \quad 60.7 \quad 52.3$ $\begin{array}{llllllllllllll}48.0 & 52.0 & 49.8 & 51.1 & 56.0 & 62.9 & 70.2 & 75.7 & 78.2 & 76.7 & 71.9 & 64.8 & 57.7\end{array}$ $\begin{array}{llllllllllllll}72.0 & 56.3 & 53.3 & 53.0 & 55.7 & 60.5 & 66.4 & 71.5 & 74.7 & 74.9 & 72.3 & 67.3 & 61.5\end{array}$ $96.0 \quad 59.6 \quad 56.4 \quad 55.2 \quad 56.2 \quad 59.3 \quad 63.8 \quad 68.2 \quad 71.5 \quad 72.8 \quad 71.7 \quad 68.5 \quad 64.2$ $\begin{array}{llllllllllllllll}120.0 & 62.1 & 59.1 & 57.3 & 57.3 & 59.0 & 62.2 & 65.7 & 68.9 & 70.7 & 70.7 & 68.9 & 65.8\end{array}$ \\ $53.4 \quad 51.3 \quad 52.5 \quad 56.963 .0 \quad 69.5 \quad 74.4 \quad 76.6 \quad 75.3 \quad 71.0 \quad 64.7 \quad 58.4$} INTEGRATED AVERAGE FROM

SURFACE TO $10 \mathrm{FT}$.

CALCULATED AUGUST EARTH TEMPERATURE AT SELECTED DIFFUSIVITIES AND SELECTED DEPTHS

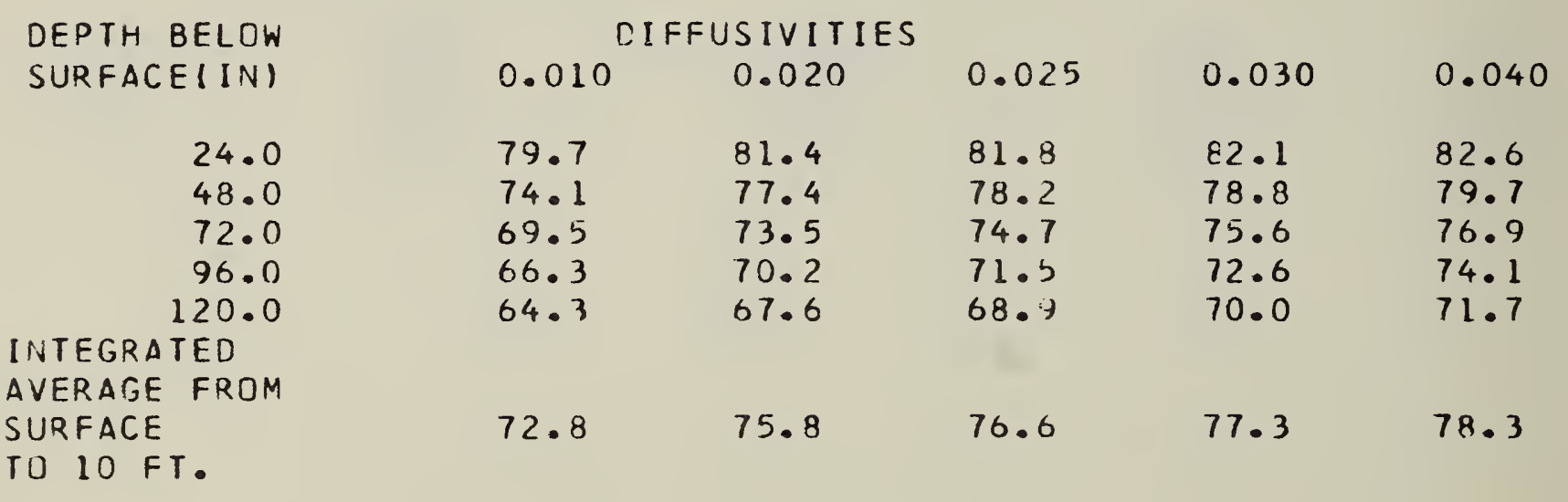


EARTH TEMPERATURE STATION

TYPE CF SOIL

TYPE DF EARTH SURFACE

DATA PROCESSEO BY

DATA SOURCE

PERIOO OF OBSERVATION
PAWHUSKA, OKLA

UNKNOWN

UNKNOWN

JEN-HU-CHANG

REFERENCE ( 5 )

$1950-1952$

\section{OBSERVED MONTHLY AVERAGE EARTH TEMPERATURES}

\section{DEPTH BELOW}

SURFACE (IN)

\section{MONTH OF YEAR}

$\begin{array}{rllllllllllll}3.9 & 41.0 & 41.2 & 45.1 & 56.1 & 69.1 & 80.6 & 81.7 & 82.6 & 74.4 & 65.6 & 48.4 & 41.4 \\ 7.9 & 39.8 & 40.9 & 43.8 & 53.9 & 65.8 & 76.6 & 79.8 & 80.8 & 73.1 & 64.4 & 48.2 & 41.2 \\ 11.8 & 44.6 & 44.6 & 48.0 & 56.4 & 65.5 & 74.4 & 78.4 & 80.8 & 74.1 & 67.6 & 55.2 & 46.8 \\ 19.7 & 46.6 & 46.3 & 49.2 & 54.1 & 64.5 & 72.1 & 77.0 & 78.7 & 74.8 & 69.0 & 58.4 & 49.6 \\ 39.4 & 50.2 & 49.0 & 50.5 & 54.6 & 63.2 & 67.4 & 73.6 & 76.5 & 74.8 & 70.2 & 62.2 & 54.1\end{array}$

DEPTH BELOW

RESLLTS OF LEAST SQUARES ANALYSIS SURFACE ( IN)

\author{
$\operatorname{AVERAGF}(A)$
}

$$
\begin{aligned}
& 60.7 \\
& 59.1 \\
& 61.5 \\
& 61.8 \\
& 62.2
\end{aligned}
$$

AMPLITUDE (B)

PHASE ANGLE(P)

22.8

21.8

18.5

16.8

13.9
0.65
0.69
1.78
0.89
1.06

$2 \cdot 1$

1.8

1.1

1.0

1.0 
CALCULATED EARTH TEMPERATURES AT SELECTED LEPTHS FOR DIFFUSIVITY $=0.025, A=62.0, B O=22.0$ AND $P O=0.61$

DEPTH BELOW MONTH OF YEAR

SURFACE.(IN)

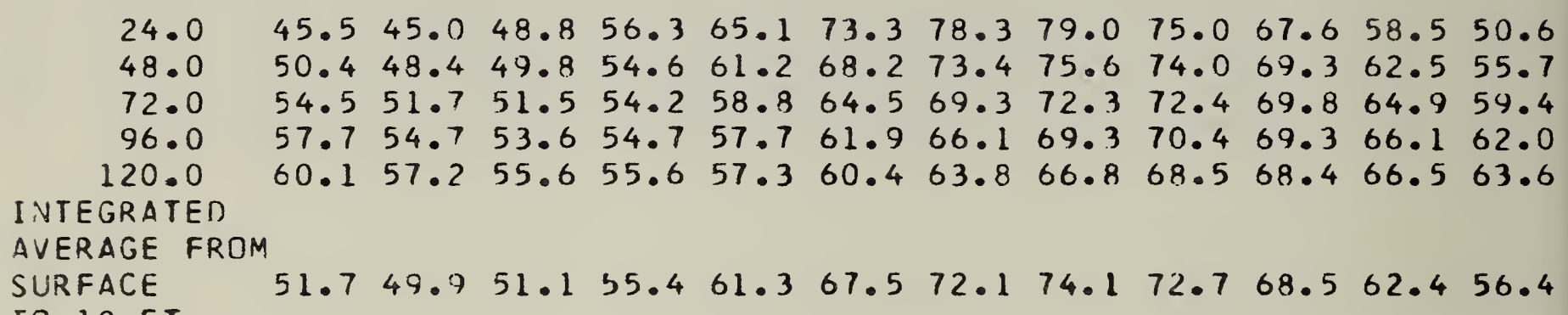

DEPTH BELOW

SURFACES IN)

INTEGRATED

$$
\begin{array}{r}
24.0 \\
49.0 \\
72.0 \\
96.0 \\
120.0
\end{array}
$$

AVERAGE FROM

SURFACE

TO $10 \mathrm{FT}$.

\begin{tabular}{lclll}
\multicolumn{5}{c}{ DIFFUSIVITIES } \\
0.010 & 0.020 & 0.025 & 0.030 & 0.040 \\
77.0 & 78.6 & 79.0 & 79.3 & 79.7 \\
71.8 & 74.8 & 75.6 & 76.2 & 77.0 \\
67.4 & 71.2 & 72.3 & 73.1 & 74.3 \\
64.3 & 68.0 & 69.3 & 70.3 & 71.8 \\
62.4 & 65.5 & 66.8 & 67.8 & 69.4
\end{tabular}

70.5

73.3

74.1

74.8

75.7 
EARTH TEMPERATURE STATION

TYPE CF SOIL

TYPE CF EARTH SURFACE

DATA PROCESSED BY

DATA SOURCE

PERIOC OF OBSERVATION
OTTAWA, OVTARIO

UNKNOWN

UNKNOWN

E. K.PENROD

REFERENCE (9)

1950

OBSERVEO MONTHLY AVERAGE EARTH TEMPERATURES

\section{DEPTH BELOW}

SURFACE (IN)

MONTH OF YEAR

$\begin{array}{lllllllllllll}12.0 & 32.6 & 30.6 & 30.8 & 35.0 & 49.7 & 58.2 & 66.0 & 63.6 & 56.9 & 48.2 & 40.2 & 34.8 \\ 24.0 & 34.9 & 33.6 & 33.0 & 34.6 & 45.8 & 57.2 & 64.1 & 63.4 & 58.8 & 51.6 & 43.5 & 38.1 \\ 48.0 & 40.2 & 38.3 & 36.7 & 36.6 & 41.9 & 50.1 & 56.3 & 58.8 & 57.9 & 54.1 & 48.4 & 42.8 \\ 96.0 & 46.0 & 44.5 & 43.1 & 41.8 & 41.6 & 43.9 & 47.5 & 50.5 & 52.3 & 52.7 & 51.4 & 48.4\end{array}$

DEPTH BELOW

RESLLTS OF LEAST SQUARES ANALYSIS

\section{SURFACE (IN)}

\section{AVERAGE $(A)$}

$$
\begin{aligned}
& 45.6 \\
& 46.6 \\
& 46.9 \\
& 47.0
\end{aligned}
$$

AMPLITUDE (B)

17.5
15.9
11.3
5.4

STANDARD

DEVIATION

2.9

2.7

1.6

0.7

CALCULATEC farth TEMPFRATURES AT OBSERVED DEPTHS(*)

DEPTH BELOW

SURFACE ( IN)

MONTH OF YEAR

$\begin{array}{llllllllllllllll}12.0 & 30.0 & 29.8 & 33.9 & 41.8 & 50.8 & 59.1 & 63.9 & 64.2 & 59.8 & 52.1 & 42.7 & 34.8\end{array}$ $24.0 \quad 33.6 \quad 32.1 \quad 34.4 \quad 40.2 \quad 47.7 \quad 55.2 \quad 60.3 \quad 61.959 .4 \quad 53.6 \quad 45.9 \quad 38.7$

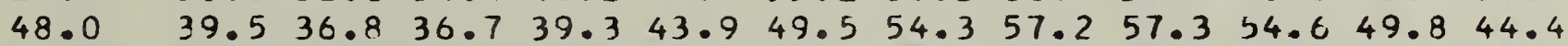

$96.0 \quad 46.5 \quad 43.9 \quad 42.2 \quad 41.7 \quad 42.6 \quad 44.7 \quad 47.450 .0 \quad 51.9 \quad 52.3 \quad 51.4 \quad 49.3$ 
CALCULATEC EARTH TEMPERATURES AT SELECTED DEPTHS

FOR DIFFUSIVITY $=0.025, A=47.0, B O=21.0$ AND $P O=0.64$

\section{MONTH OF YEAR}

\section{DEPTH BELOW}

SURFACE (IN)

$\begin{array}{rllllllllllll}24.0 & 31.5 & 30.7 & 34.0 & 41.1 & 49.5 & 57.4 & 62.4 & 63.3 & 59.7 & 52.8 & 44.1 & 36.5 \\ 48.0 & 36.2 & 34.0 & 35.2 & 39.6 & 45.8 & 52.6 & 57.7 & 60.0 & 58.7 & 54.3 & 47.8 & 41.3 \\ 72.0 & 40.1 & 37.2 & 36.9 & 39.3 & 43.7 & 49.1 & 53.7 & 56.7 & 57.0 & 54.6 & 50.1 & 44.8 \\ 96.0 & 43.1 & 40.1 & 39.0 & 39.9 & 42.7 & 46.7 & 50.7 & 53.8 & 55.1 & 54.1 & 51.2 & 47.2 \\ 120.0 & 45.3 & 42.5 & 40.9 & 40.9 & 42.4 & 45.3 & 48.5 & 51.4 & 53.1 & 53.1 & 51.5 & 48.7\end{array}$
INTEGRATED AVERAGE FROM

SURFACE $37.4 \quad 35.5 \quad 36.5 \quad 40.4 \quad 45.9 \quad 52.0 \quad 56.5 \quad 58.5 \quad 57.4 \quad 53.5 \quad 47.8 \quad 42.0$ TO $10 \mathrm{FT}$.

CALCULATED AUGUST EARTH TFMPERATURE AT SELECTED DIFFUSIVITIES AND SELECTED DEPTHS

DEPTH BELOW

SURFACE ( IN)

$$
\begin{array}{r}
24.0 \\
48.0 \\
72.0 \\
96.0 \\
120.0
\end{array}
$$

INTEGRATED

AVERAGE FROM

SURFACE

TO $10 \mathrm{FT}$.

\begin{tabular}{lclll}
\multicolumn{5}{c}{ DIFFUSIVITIES } \\
0.010 & 0.020 & 0.025 & 0.030 & 0.040 \\
61.4 & 62.9 & 63.3 & 63.6 & 64.0 \\
56.2 & 59.2 & 60.0 & 60.6 & 61.4 \\
52.0 & 55.7 & 56.7 & 57.5 & 58.7 \\
49.0 & 52.6 & 53.8 & 54.8 & 56.2 \\
47.2 & 50.3 & 51.4 & 52.4 & 54.0
\end{tabular}

55.0

$57.7 \quad 58.5$

59.2

60.1 
EARTH TEMPERATURE STATION

TYPE OF SOIL

TYPE OF EARTH SURFACE

DATA PROCESSED BY

DATA SOURCE

PERICD OF OBSERVATION
COR VALLIS, OREGON

CLAY LOAM

UN KNDWN

CLIMATOLUGICAL DATA

$1961-1962$

\section{ORSERVED MUNTHLY AVERAGE EARTH TEMPERATURES}

DEPTH BELOW

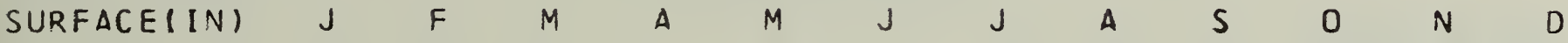

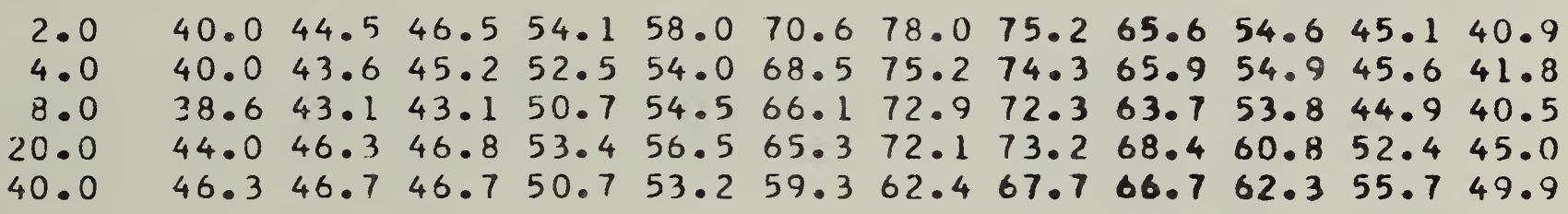

DEPTH BELOW

RESULTS OF LEAST SQUARES ANALYSIS SURFACE (IN)

AVERAGE (A)

AMPLITUDE (B)

PHASE ANGLE (P)
17.9
16.9
16.4
14.5
10.7

C. 56
C. 64
C. 65
0.81
1.13

C. 56

C. 64

0.81

1.13
STANDARD

DEVIATION

3. 3

3.6

3.0

2.4

1.7

CALCulatec eARTH temperatures at obSERVED CEPTHS(

DEPTH BELOW

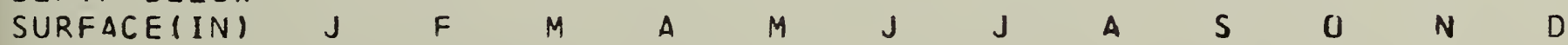
MONTH OF YEAR

$\begin{array}{lllllllllllllllll}2.0 & 38.5 & 40.6 & 46.4 & 55.2 & 63.9 & 70.8 & 73.5 & 71.5 & 65.2 & 56.7 & 47.7 & 41.2\end{array}$ $\begin{array}{llllllllllllll}4.0 & 39.0 & 40.8 & 46.3 & 54.7 & 63.3 & 70.1 & 72.9 & 71.3 & 65.4 & 57.1 & 48.3 & 41.9\end{array}$

$\begin{array}{llllllllllllll}8.0 & 40.1 & 41.3 & 46.1 & 53.9 & 62.0 & 68.7 & 71.9 & 70.8 & 65.6 & 58.0 & 49.6 & 43.2\end{array}$

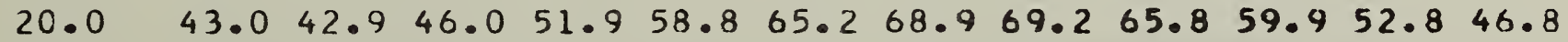
$40.0 \quad 47.5 \quad 45.9 \quad 46.9 \quad 50.3 \quad 55.2 \quad 60.5 \quad 64.4 \quad 66.165 .0 \quad 61.6 \quad 56.5 \quad 51.4$ 
CALCULATEC EARTH TEMPERATURES AT SELECTED CEPTHS

FOR DIFFUSIVITY $=0.025, A=56.0, B O=18.0$ AND $P O=0.53$

MONTH OF YEAR

DEPTH BELOW

SURFACE! IN

$$
24.0
$$

$$
42.242 .4
$$

48.0

72.0

96.0

120.0

$\begin{array}{lllllllllllll}42.2 & 42.4 & 45.9 & 52.4 & 59.6 & 66.1 & 69.7 & 69.6 & 65.8 & 59.5 & 52.0 & 45.8\end{array}$ $\begin{array}{lllllllllllll}46.1 & 44.9 & 46.4 & 50.7 & 56.2 & 61.9 & 65.8 & 67.1 & 65.4 & 61.2 & 55.5 & 50.1\end{array}$ $\begin{array}{llllllllllll}49.4 & 47.4 & 47.6 & 50.1 & 54.1 & 58.7 & 62.5 & 64.6 & 64.3 & 61.8 & 57.7 & 53.2\end{array}$ $\begin{array}{llllllllllll}52.0 & 49.7 & 49.1 & 50.3 & 52.9 & 56.5 & 59.8 & 62.2 & 62.9 & 61.7 & 58.9 & 55.4\end{array}$ INTEGRATED $\begin{array}{lllllllllllll}54.0 & 51.8 & 50.7 & 50.9 & 52.5 & 55.1 & 57.4 & 60.2 & 61.4 & 61.1 & 59.4 & 56.8\end{array}$ AVERAGE FROM

SURFACE

$47.2 \quad 46.1 \quad 47.5 \quad 51.3 \quad 56.2 \quad 61.2 \quad 64.7 \quad 65.9 \quad 64.4 \quad 60.7 \quad 55.6 \quad 50.7$

TO $10 \mathrm{FT}$.

CALCULATED AUGUST EARTH TEMPERATURE AT SELECTED DIFFUSIVITIES AND SELECTED DEPTHS

DEPTH BELOW

SURFACE (IN)

$$
\begin{array}{r}
24.0 \\
48.0 \\
72.0 \\
96.0 \\
120.0
\end{array}
$$

INTEGRATED

\section{AVERAGE FROM}

SURFACE

TO $10 \mathrm{FT}$.

\begin{tabular}{lcccc}
\multicolumn{5}{c}{ DIFFUSIVITIES } \\
0.010 & 0.020 & 0.025 & 0.030 & 0.040 \\
68.2 & 69.4 & 69.6 & 69.8 & 70.1 \\
64.2 & 66.5 & 67.1 & 67.6 & 68.2 \\
60.7 & 63.7 & 64.6 & 65.2 & 66.2 \\
58.1 & 61.2 & 62.2 & 63.0 & 64.2 \\
56.5 & 59.2 & 60.2 & 61.0 & 62.3
\end{tabular}

63.0

65.3

65.9

66.4

67.2 


\section{EARTH TEMPERATURE STATION}

TYPE CF SOIL

TYPE OF EARTH SURFACE

DATA PROCESSED BY

DATA SOURCE

PERIOD OF OESERVATION
PENDLETON, OREGON

$S T-52$

THIN GRASS

E. M.FITTON

REFERENCE (4)

1850

OBSERVED MONTHLY AVFRAGE EARTH TEMPERATURES

MONTH OF YEAR

DEPTH BELOW

SURFACE(IN) J

$\begin{array}{llllllllllllll}4.0 & 26.7 & 37.3 & 44.9 & 62.2 & 72.3 & 74.2 & 84.6 & 83.3 & 73.2 & 57.4 & 45.8 & 40.9\end{array}$

$\begin{array}{llllllllllllll}8.0 & 27.8 & 36.6 & 40.9 & 55.3 & 66.3 & 68.4 & 77.6 & 75.8 & 66.5 & 53.7 & 43.2 & 41.8\end{array}$

$\begin{array}{llllllllllllll}12.0 & 30.4 & 37.1 & 39.8 & 52.2 & 63.1 & 65.8 & 73.7 & 73.3 & 65.7 & 54.1 & 45.2 & 40.5\end{array}$

$24.0 \quad 34.6 \quad 38.1 \quad 40.1 \quad 50.1 \quad 60.9 \quad 63.7 \quad 71.0 \quad 71.7 \quad 66.7 \quad 57.3 \quad 48.5 \quad 45.0$

RESULTS OF LEAST SQUARES ANALYSIS

DEPTH BELOW

SURFACE(IN) AVERAGE(A)

$\begin{array}{rl}4.0 & 58.2 \\ 8.0 & 54.0 \\ 12.0 & 53.2 \\ 24.0 & 53.7\end{array}$

\section{AMPLITUDE (B) PHASE ANGLE(P)}

0.52

C. 54

0.62

C. 75

26.4
22.9
20.4
18.0
STANDARD

DEVIATION
3.6

2.6

2.1 
CALCULATEC FARTH TEMPERATURES AT SELECTED CEPTHS

FOR DIFFUSIVITY $=0.025, A=53.0, B O=26.0$ AND $P O=0.48$

\section{DEPTH BELOW}

SURFACE (IN)

\section{MONTH OF YEAR}

\begin{tabular}{|c|c|c|c|c|c|c|c|c|c|c|c|c|}
\hline $\begin{array}{r}24.0 \\
48.0 \\
72.0 \\
36.0 \\
120.0\end{array}$ & $\begin{array}{l}32.9 \\
38.3 \\
43.0 \\
46.8 \\
49.8\end{array}$ & $\begin{array}{l}33.6 \\
37.0 \\
40.5 \\
43.8 \\
46.6\end{array}$ & $\begin{array}{l}39.2 \\
39.6 \\
41.1 \\
43.1 \\
45.2\end{array}$ & $\begin{array}{l}48.8 \\
46.0 \\
45.0 \\
45.0 \\
45.8\end{array}$ & $\begin{array}{l}59.2 \\
54.1 \\
50.9 \\
49.0 \\
48.3\end{array}$ & $\begin{array}{l}68 \cdot 3 \\
62 \cdot 1 \\
57 \cdot 5 \\
54 \cdot 2 \\
52 \cdot 1\end{array}$ & $\begin{array}{l}73.0 \\
67.5 \\
62.8 \\
59.0 \\
56.1\end{array}$ & $\begin{array}{l}72.4 \\
69.0 \\
65.5 \\
62.2 \\
59.3\end{array}$ & $\begin{array}{l}66.4 \\
66.1 \\
64.8 \\
62.9 \\
60.8\end{array}$ & $\begin{array}{l}57.0 \\
59.8 \\
60.9 \\
60.9 \\
60.2\end{array}$ & $\begin{array}{l}46.3 \\
51.5 \\
54.8 \\
56.7 \\
57.6\end{array}$ & $\begin{array}{l}37.6 \\
43.8 \\
48.4 \\
51.7 \\
53.8\end{array}$ \\
\hline $\begin{array}{l}\text { INTEGRATED } \\
\text { AVERAGE FROM }\end{array}$ & & & & & & & & & & & & \\
\hline SURFACE & 40.0 & 38.7 & 41.1 & 46.8 & 54.0 & 61.1 & 65.9 & 67.3 & 64.7 & 59.1 & 51.6 & 44.8 \\
\hline
\end{tabular}

\section{CALCULATED AUGUST EARTH TEMPERATURE AT SELECTED DIFFUSIVITIES} AND SELECTED DEPTHS

DEPTH BELOW

SURFACE (IN)

24.0

48.0

72.0

96.0

120.0

INTEGRATED

AVERAGE FROM

SURFACE

TO $10 \mathrm{FT}$.

\begin{tabular}{lllll}
\multicolumn{5}{c}{ DIFFUSIVITIES } \\
0.010 & 0.020 & 0.025 & 0.030 & 0.040 \\
70.5 & 72.0 & 72.4 & 72.7 & 73.0 \\
65.0 & 68.2 & 69.0 & 69.7 & 70.5 \\
60.0 & 64.3 & 65.5 & 66.4 & 67.7 \\
56.3 & 60.8 & 62.2 & 63.3 & 65.0 \\
53.9 & 57.9 & 59.3 & 60.5 & 62.3
\end{tabular}

$\begin{array}{lllll}63.2 & 66.4 & 67.3 & 68.0 & 69.0\end{array}$


EARTH TEMPERATURE STATION

TYPE CF SOIL

TYPE OF FARTH SURFACE

DATA PROCESSED BY

DATA SOURCE

PERIOC OF OBSERVATION
CALHOUN, S.C.

UNKNOWN

BARE

JEA-MU-CHANG

RFFERENCE (5)

$1950-1951$

OBSERVED MONTHLY AVERAGE EARTH TEMPERATURES

DEPTH BELOW

SURFACE (IN)

$\begin{array}{lllllllllllllll}2.0 & 40.0 & 41.0 & 49.4 & 57.3 & 67.2 & 75.1 & 78.1 & 77.2 & 70.8 & 59.0 & 43.7 & 40.4\end{array}$

$\begin{array}{lllllllllllllll}12.0 & 42.6 & 44.1 & 51.4 & 57.7 & 70.6 & 76.8 & 80.2 & 80.7 & 74.7 & 67.1 & 51.9 & 44.0\end{array}$

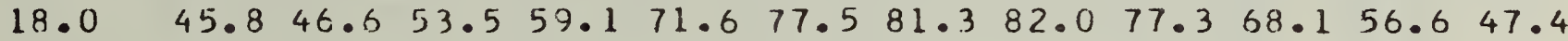

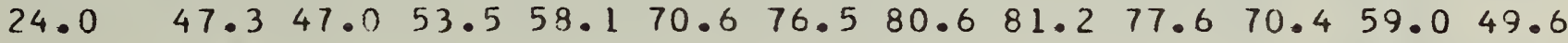

$\begin{array}{llllllllllllll}36.0 & 48.7 & 47.8 & 52.7 & 56.4 & 67.5 & 73.1 & 78.2 & 78.8 & 77.0 & 71.1 & 62.1 & 52.8\end{array}$

$\begin{array}{llllllllllllll}48.0 & 50.4 & 49.2 & 52.6 & 55.6 & 65.0 & 70.4 & 76.2 & 77.3 & 76.6 & 71.6 & 64.2 & 55.9\end{array}$

$\begin{array}{lllllllllllllll}60.0 & 52.9 & 51.2 & 53.4 & 56.3 & 64.1 & 69.4 & 74.7 & 75.9 & 76.6 & 72.8 & 66.7 & 59.3\end{array}$

$\begin{array}{llllllllllllllll}72.0 & 54.7 & 52.4 & 53.7 & 55.9 & 62.5 & 67.9 & 71.9 & 74.3 & 75.3 & 72.8 & 67.7 & 61.6\end{array}$

DEPTH BELOW

RESLLTS OF LEAST SQUARES ANALYSIS

\section{SURFACE (IN)}

$\begin{array}{rr}2.0 & 58.5 \\ 12.0 & 61.9 \\ 18.0 & 64.0 \\ 24.0 & 64.4 \\ 36.0 & 63.9 \\ 48.0 & 63.8 \\ 60.0 & 64.5 \\ 72.0 & 64.3\end{array}$

\section{AMPLITUDE (B)}

$20 \cdot 5$
19.9
18.9
17.9
16.0
14.4
12.9
11.5

STANDARD DEVIATION

2.0
1.7
1.4
1.4
1.2
0.9
0.9
0.9

0.9

CALCULATED EARTH TEMPERATURES AT OBSERVED [EPTHS(*)

DEPTH BELOW

SURFACE (IN)

MONTH OF YEAR

2. 0

12.0

18.0

24.0

36.0

48.0

60.0

72.0

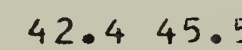

45.746 .952 .3

$47.0 \quad 47.5 \quad 52.2$

$49.3 \quad 48.9 \quad 52.2$

$51.5 \quad 50.3 \quad 52.6$

$53.6 \quad 51.8 \quad 53.1$

55.5

$53.3 \quad 53.8$

$M \quad A$

M

J

J

C. 51

C. 65

C. 69

0.77

C. 91

1.04

1.16

1.28

\section{(*) BASIC PARAMETERS USED for the CALCULATION}

$A=64.0, B O=22.0, P C=0.49, D=.026$ 
CALCULATEO EARTH TEMPERATURES AT SELECTED CEPTHS

FUR DIFFUSIVITY $=0.025, \quad A=64.0, B O=22.0$ AND $P O=0.49$

DEPTH BELOW

SURFACE (IN)

MONTH OF YEAR

$$
\begin{array}{rllllllllllll}
24.0 & 47.0 & 47.6 & 52.2 & 60.3 & 69.1 & 76.8 & 80.9 & 80.5 & 75.5 & 67.6 & 58.5 & 51.1 \\
48.0 & 51.6 & 50.4 & 52.6 & 58.0 & 64.8 & 71.6 & 76.2 & 77.6 & 75.2 & 69.9 & 62.8 & 56.3 \\
72.0 & 55.6 & 53.4 & 53.9 & 57.1 & 62.1 & 67.7 & 72.2 & 74.6 & 74.0 & 70.8 & 65.6 & 60.2 \\
96.0 & 58.9 & 56.2 & 55.6 & 57.2 & 60.6 & 65.0 & 69.0 & 71.8 & 72.4 & 70.8 & 67.2 & 63.0 \\
120.0 & 61.3 & 58.7 & 57.4 & 57.9 & 59.9 & 63.2 & 66.5 & 69.3 & 70.6 & 70.1 & 67.9 & 64.8
\end{array}
$$
INTEGRATED

AVERAGE FROM
SURFACE
TO $10 \mathrm{FT}$.
$53.0 \quad 51.9 \quad 53.9 \quad 58.6 \quad 64.7 \quad 70.8 \quad 74.9 \quad 76.1 \quad 74.0 \quad 69.3 \quad 63.0 \quad 57.1$

CALCULATEC AUGUST EARTH TEMPERATURE AT SELECTED DIFFUSIVITIES AND SELECTED DEPTHS

DEPTH BELOW

SURFACE (IN)

24.0
48.0
72.0
96.0
120.0

I NTEGRATED

AVERAGE FROM

SURFACF

TO $10 \mathrm{FT}$.

\begin{tabular}{lcccc}
\multicolumn{5}{c}{ DIFFUSIVITIES } \\
0.010 & 0.020 & 0.025 & 0.030 & 0.040 \\
78.8 & 80.2 & 80.5 & 80.7 & 81.0 \\
74.1 & 76.9 & 77.6 & 78.1 & 78.8 \\
69.9 & 73.5 & 74.6 & 75.4 & 76.5 \\
66.8 & 70.5 & 71.8 & 72.7 & 74.1 \\
64.8 & 68.1 & 69.3 & 70.3 & 71.9
\end{tabular}

72.6

75.3

$76 \cdot 1$

76.7

77.6 
EARTH TEMPERATURE STATION

TYPE CF SOIL

TYPE OF EARTH SURFACE

DATA PROCESSED BY

DATA SOURCE

PERICO OF OESERVATION
UNION, S.C.

SANDY LOAM

GRASS SOD

CLIMATOLOGICAL DATA

$1960-1962$

OBSERVED MONTHLY AVERAGE EARTH TEMPERATURES

\section{DEP TH BELOW}

SURFACE (IN)

\section{MONTH OF YEAR}

$\begin{array}{llllllllllllllll}1.0 & 37.0 & 39.7 & 42.8 & 54.1 & 65.7 & 73.1 & 76.4 & 75.6 & 72.2 & 59.9 & 51.7 & 38.9\end{array}$

$\begin{array}{llllllllllllll}4.0 & 38.6 & 41.3 & 44.1 & 54.9 & 66.2 & 73.1 & 77.1 & 76.7 & 72.9 & 62.0 & 53.3 & 41.0\end{array}$

$12.0 \quad 40.9 \quad 43.5 \quad 46.2 \quad 56.1 \quad 67.2 \quad 74.178 .178 .2 \quad 74.6 \quad 65.2 \quad 56.5 \quad 43.8$

RESLLTS OF LEAST SQUARES ANALYSIS DEPTH BELOW SURFACE(IN) AVERAGE(A)

AMPLITUDE (B)

$$
\begin{aligned}
& 20.4 \\
& 19.8 \\
& 19.2
\end{aligned}
$$

STANDARD DEVIATION
C. 68
0.70
C. 75

2.8

2.8

2.8 


\section{CALCULATED EARTH TEMPERATURES AT SELECTED CEPTHS}

$$
\text { FOR DIFFUSIVITY }=0.025, \quad A=59.0, B O=20.0 \text { AND } P O=0.67
$$

\section{DEPTH BELOW}

\section{SURFACE(IN)}

\section{MONTH OF YEAR}

$$
\begin{array}{r}
24.0 \\
48.0 \\
72.0 \\
96.0 \\
120.0
\end{array}
$$

$$
\begin{array}{llllllllllll}
44.4 & 43.4 & 46.4 & 52.9 & 60.9 & 68.6 & 73.5 & 74.6 & 71.4 & 65.0 & 56.7 & 49.3 \\
48.9 & 46.7 & 47.6 & 51.6 & 57.5 & 64.0 & 68.4 & 71.3 & 70.3 & 66.3 & 60.2 & 53.9 \\
52.6 & 49.8 & 49.4 & 51.5 & 55.6 & 60.7 & 65.2 & 68.2 & 68.6 & 66.4 & 62.2 & 57.2 \\
55.5 & 52.6 & 51.4 & 52.1 & 54.7 & 58.5 & 62.3 & 65.4 & 66.7 & 65.9 & 63.2 & 59.4 \\
57.6 & 54.7 & 53.3 & 53.1 & 54.5 & 57.2 & 60.3 & 63.1 & 64.8 & 64.9 & 63.4 & 60.8
\end{array}
$$

INTEGRATED

AVERAGE FROM

SURFACE

$50.0 \quad 48.0 \quad 48.8 \quad 52.4 \quad 57.7 \quad 63.4 \quad 67.8 \quad 70.0 \quad 69.0 \quad 65.560 .0 \quad 54.5$ TO $10 \mathrm{FT}$.

CALCULATED AUGUST EARTH TEMPERATURE AT SELECTED DIFFUSIVITIES AND SELECTED DEPTHS

DEPTH BELOW

SURFACE (IN)

$$
\begin{array}{r}
24.0 \\
48.0 \\
72.0 \\
96.0 \\
120.0
\end{array}
$$

I NTEGRATED

AVERAGE FROM

SURFACE

TO $10 \mathrm{FT}$.

\begin{tabular}{lclll}
\multicolumn{5}{c}{ DIFFUSIVITIES } \\
0.010 & 0.020 & 0.025 & 0.030 & 0.040 \\
72.7 & 74.2 & 74.6 & 74.9 & 75.3 \\
67.7 & 70.5 & 71.3 & 71.9 & 72.7 \\
63.6 & 67.1 & 68.2 & 69.0 & 70.1 \\
60.8 & 64.2 & 65.4 & 66.3 & 67.7 \\
59.1 & 62.0 & 63.1 & 64.0 & 65.5 \\
& & & & \\
66.6 & 69.2 & 70.0 & 70.6 & 71.5
\end{tabular}


EARTH TEMPERATURE STATION

TYPE CF SOIL

TYPE CF FARTH SURFACE

DATA PROCESSED BY

DATA SOURCE

PERICL OF OESERVATION
MAOISON, S.D.

SILTY CLAY

GRASS SDD

CLIMATOLOGICAL DATA

$1961-1962$

OBSERVED MONTHLY AVERAGE EARTH TEMPERATURES

\section{DEPTH BELOW}

SURFACE (IN)

MONTH OF YEAR

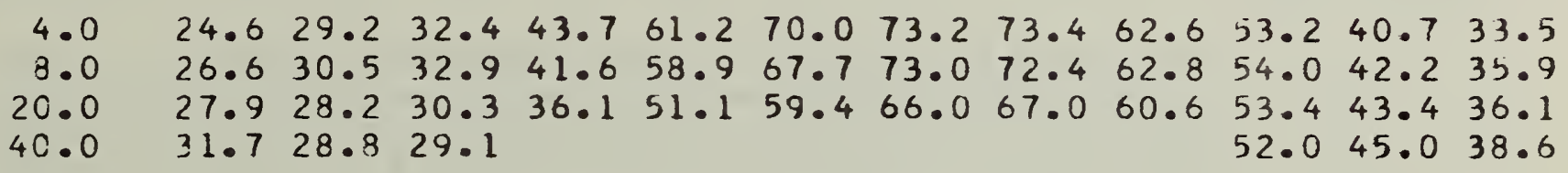

DEPTH BELOW

RESLLTS OF LEAST SQUARES ANALYSIS

SURFACE (IN)

AVERAGE (A)

AMPLITUDE ( 8 )

PHASE ANGLE(P)

$24 \cdot 0$
22.5
$19 \cdot 7$
13.9
C. 67

0.73

C. 90

1.27

$\begin{array}{rll}4.0 & 50.1 & 24.0 \\ 8.0 & 50.1 & 22.5 \\ 20.0 & 46.8 & 19.7 \\ 40.0 & 42.4 & 13.9\end{array}$

STANDARD DEVIATION

2.2

2.3

1.9

0.6

CALCULATEC EARTH TEMPERATURES AT OBSERVED [EPIHS(*)

DEPTH BELOW

MONTH OF YEAR

SURFACE (IN)

4.0

$22.8 \quad 24.5 \quad 31.7 \quad 43$.

$A$

M

J

8.0

$24.5 \quad 25.4 \quad 31.6 \quad 42$.

555.9

66.2

20.0

$29.5 \quad 28.3 \quad 31.939 .7$

40.0

$36.6 \quad 33.6 \quad 34.0$

$38.0 \quad 44.2$

64.169 .3

$\begin{array}{lllll}69.6 & 61.8 & 50.2 & 37.5 & 27.7\end{array}$ 
CALCULATEC EARTH TEMPERATURES AT SELECTED CEPTHS

FOR DIFFUSIVITY $=0.025, A=47.0, B \cap=26.0$ AND $P O=0.59$

\section{DEPTH BELOW}

SURFACE(IN)

\section{MONTH OF YEAR}
24.0
27.427.
$\begin{array}{lllllllllllll}24.6 & 27.0 & 31.6 & 40.6 & 51.0 & 60.7 & 66.4 & 67.0 & 62.0 & 53.2 & 42.4 & 33.2\end{array}$

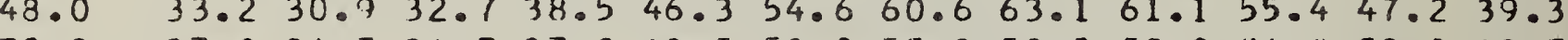
$\begin{array}{lllllllllllllll}72.0 & 37.9 & 34.7 & 34.7 & 37.9 & 43.5 & 50.2 & 55.8 & 59.2 & 59.2 & 56.0 & 50.2 & 43.7\end{array}$
$96.0 \quad 41.7 \quad 38.2 \quad 37.0 \quad 38.4 \quad 42.0 \quad 47.1 \quad 52.0 \quad 55.7 \quad 57.0 \quad 55.5 \quad 51.7 \quad 46.8$
$\begin{array}{lllllllllllll}120.0 & 44.6 & 41.2 & 39.4 & 39.5 & 41.6 & 45.2 & 49.3 & 52.8 & 54.7 & 54.5 & 52.3 & 48.7\end{array}$ INTEGRATED
AVERAGE FROM
$\begin{array}{lllllllllllllll}\text { SURFACE } & 34.7 & 32.7 & 34.3 & 39.4 & 46.4 & 53.8 & 59.1 & 61.3 & 59.5 & 54.5 & 47.2 & 40.1\end{array}$ TO $10 \mathrm{FT}$.

F $\quad M$

A

M

A S

ON

D

\section{CALCULATEC AUGUST EARTH TEMPERATURE AT SELECTED DIFFUSIVITIES AND SELECTED DEPTHS}

DEPTH BELOW

SURFACE (IN)

$$
\begin{array}{r}
24.0 \\
48.0 \\
72.0 \\
96.0 \\
120.0
\end{array}
$$

INTEGRATED

AVERAGE FROM

SURFACE

TO $10 \mathrm{FT}$.

\begin{tabular}{lcccc}
\multicolumn{5}{c}{ DIFFUSIVITIES } \\
0.010 & 0.020 & 0.025 & 0.030 & 0.040 \\
64.8 & 66.6 & 67.0 & 67.3 & 67.8 \\
58.6 & 62.2 & 63.1 & 63.8 & 64.8 \\
53.5 & 57.9 & 59.2 & 60.2 & 61.6 \\
49.8 & 54.3 & 55.7 & 56.9 & 58.6 \\
47.5 & 51.3 & 52.8 & 54.0 & 55.9
\end{tabular}

$57.1 \quad 60.3$

$61 \cdot 3$

62.1

63.2 
EARTH TEMPERATURE STATION

TYPE CF SOIL

TYPE CF EARTH SURFAC.F.

DATA PROCESSEO BY

DATA SOURCE

PERICC OF OBSERVATION
JACKSON, TENN.

$S T-56$

SILT LOAM

CDARSE GRASS

US WEATHER R.C.

$1949-1951$

\section{OBSERVEU MONTHLY AVERAGE EARTH TEMPERATURES}

\section{DEPTH BELOW}

MONTH OF YEAR

SURFACEIIN

$\begin{array}{rllllllllllll}4.0 & 43.3 & 43.8 & 50.6 & 59.8 & 67.6 & 75.6 & 79.0 & 75.8 & 70.1 & 61.3 & 44.7 & 41.1 \\ 12.0 & 45.2 & 45.1 & 48.0 & 54.7 & 64.5 & 74.3 & 76.6 & 75.2 & 70.1 & 61.5 & 47.3 & 43.1 \\ 24.0 & 49.1 & 46.8 & 50.7 & 53.8 & 63.8 & 68.8 & 73.1 & 73.4 & 69.8 & 65.1 & 51.6 & 48.3 \\ 49.0 & 50.5 & 50.1 & 51.3 & 53.7 & 60.2 & 66.0 & 69.7 & 70.4 & 69.6 & 64.6 & 56.8 & 51.7 \\ 72.0 & 52.1 & 51.4 & 51.4 & 52.2 & 56.8 & 60.9 & 64.1 & 65.8 & 67.3 & 65.0 & 60.1 & 53.8\end{array}$

RESULTS OF LEAST SQUARES ANALYSIS

DEPTH BELOW

SURFACE (IN)

$\begin{array}{rl}4.0 & 59.5 \\ 12.0 & 58.8 \\ 24.0 & 59.6 \\ 48.0 & 59.6 \\ 72.0 & 58.5\end{array}$

AMPLITUDE (B)

PHASE ANGLE(P)

$$
\begin{array}{r}
19.1 \\
17.5 \\
13.8 \\
10.9 \\
8.2
\end{array}
$$

0.49

C. 62

0.77

C. 94

1.25
ST ANDARD

DEVIATION

3.8

3.2

2.6

$1 \cdot 3$

1.2

CALCULATEC EARTH TEMPERATURES AT OBSERVED CEPTHS(*)

DEPTH BELOW SURFACE (IN)
MONTH OF YEAR

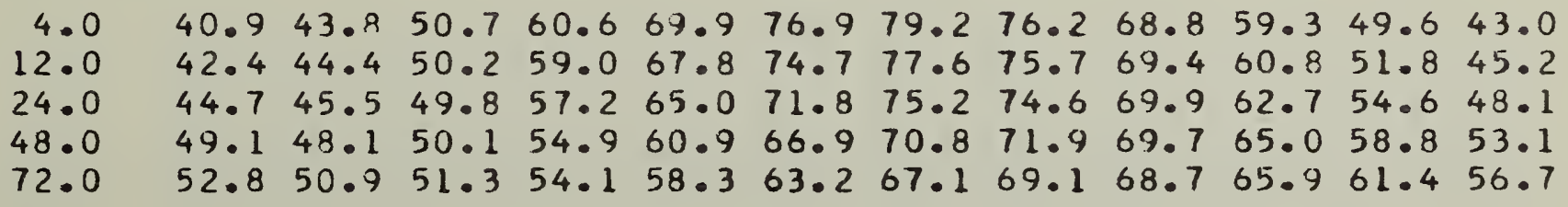


CALCULATEC EARTH TEMPERATURES AT SELECTED CEPTHS

FOR DIFFUSIVITY $=0.025, \quad A=60.0, B O=20.0$ AND $P O=0.44$

MONTH OF YFAR

DEPTH BELOW

SURFACE I IN)

$\begin{array}{lllllllllllll}24.0 & 44.4 & 45.3 & 49.8 & 57.4 & 65.4 & 72.2 & 75.5 & 74.7 & 69.8 & 62.5 & 54.2 & 47.8 \\ 48.0 & 48.5 & 47.7 & 50.0 & 55.1 & 61.4 & 67.4 & 71.4 & 72.3 & 69.8 & 64.8 & 58.3 & 52.5 \\ 72.0 & 52.1 & 50.3 & 51.0 & 54.1 & 58.7 & 63.8 & 67.8 & 69.7 & 68.9 & 65.8 & 61.0 & 56.1 \\ 96.0 & 55.0 & 52.8 & 52.4 & 54.1 & 57.2 & 61.3 & 64.8 & 67.2 & 67.6 & 65.9 & 62.6 & 58.7 \\ 120.0 & 57.3 & 55.0 & 54.0 & 54.6 & 56.5 & 59.5 & 62.6 & 65.0 & 66.0 & 65.4 & 63.3 & 60.4\end{array}$ INTEGRATED

AVERAGE FROM

$\begin{array}{llllllllllllllll} & 4\end{array}$ TO 10 FT.

CALCULATEC AUGUST EARTH TEMPERATURE AT SELECTED DIFFUSIVITIES AND SELECTED DEPTHS

DEPTH BELOW

SURFACEI IN )

I VTEGRATED

24.0

48.0

72.0

96.0

120.0

AVERAGE FROM

SURFACE

TO $10 \mathrm{FT}$.
DIFFUSIVITIES

$\begin{array}{lllll}0.010 & 0.020 & 0.025 & 0.030 & 0.040 \\ 73.4 & 74.5 & 74.7 & 74.9 & 75.2 \\ 69.3 & 71.7 & 72.3 & 72.7 & 73.4 \\ 65.5 & 68.8 & 69.7 & 70.4 & 71.3 \\ 62.7 & 66.1 & 67.2 & 68.0 & 69.3 \\ 60.8 & 63.9 & 65.0 & 65.9 & 67.3\end{array}$

67.9

70.3

70.9

71.5

72.2 
EARTH TEMPERATURE STATION

TYPE OF SOIL

TYPE CF EARTH SURFACE

DATA PROCESSED BY

DATA SOURCE

PERICL OF OESERVATION
TEMPLE, TEXAS

HORTICUL TURAL

US WEATHER R.C.

$1919-1924$

OBSERVED MONTHLY AVERAGE EARTH TEMPERATURES

MONTH OF YEAR

\title{
DEPTH BELOW
}

SURFACE (IN)

$\begin{array}{rllllllllllll}1.0 & 50.8 & 53.3 & 59.4 & 68.3 & 79.9 & 85.3 & 92.0 & 92.5 & 84.1 & 72.6 & 58.8 & 53.0 \\ 3.0 & 50.7 & 52.7 & 58.7 & 67.8 & 79.0 & 84.9 & 90.7 & 92.3 & 83.9 & 71.8 & 58.2 & 52.7 \\ 6.0 & 51.8 & 53.2 & 58.8 & 64.6 & 78.3 & 83.6 & 89.8 & 90.9 & 83.3 & 71.7 & 61.0 & 53.7 \\ 12.0 & 52.9 & 53.9 & 58.6 & 65.8 & 75.9 & 83.5 & 87.0 & 88.6 & 83.4 & 73.5 & 62.6 & 55.4 \\ 24.0 & 55.9 & 55.3 & 58.6 & 64.8 & 72.6 & 78.9 & 83.1 & 87.4 & 82.6 & 75.8 & 65.6 & 58.8 \\ 36.0 & 58.8 & 57.6 & 59.5 & 64.2 & 70.5 & 76.5 & 80.8 & 83.8 & 82.2 & 77.9 & 69.1 & 62.1 \\ 48.0 & 55.5 & 58.9 & 60.2 & 63.5 & 67.8 & 74.2 & 78.4 & 81.4 & 81.0 & 77.7 & 70.8 & 64.6\end{array}$

DEPTH BELOW

RESULTS OF LEAST SQUARES ANALYSIS SURFACEI IN )

AVERAGF (A)

$70 \cdot 9$
$70 \cdot 4$
$70 \cdot 1$
$70 \cdot 2$
$70 \cdot 0$
70.3
69.6

69.6
AMPL ITUDE (B)

$21 \cdot 1$
$20 \cdot 9$
$19 \cdot 8$
$18 \cdot 2$
$15 \cdot 6$
$13 \cdot 2$
$12 \cdot 1$

1.0

3.0

6.0

12.0

24.0

36.0

$48 \cdot 0$

CALCULATEC FARTH TEMPERATURES AT OBSERVED [EPTHS(*)

DEPTH BELOW

SURFACE (IN)

MONTH OF YEAR

1.0

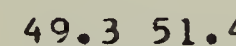

3.0

$49.8 \quad 51.6 \quad 57.967 .978$.

6.0

$\begin{array}{llllll}50.5 & 52.0 & 57.8 & 67.3 & 77.3\end{array}$

M

PHASE ANGLE(P)

STANDARD DEVIATION

12.0

$52.0 \quad 52.757 .7 \quad 66.375 .6$

C. 60

C. 61

0.67

C. 71

0.86

1.02

1.12

$4 \cdot 2$

3.9

3.9

2.9

2.7

1.9

4.0

24.0

$\begin{array}{lllll}54.9 & 54.4 & 57.7 & 64.6 & 72.7\end{array}$

$57.6 \quad 56.2 \quad 58.2 \quad 63.6 \quad 70.5$

$60.0 \quad 58.0 \quad 59.0 \quad 63.0 \quad 68.7$

48.0

\begin{abstract}
60.0
\end{abstract}
1

*) basic parameters used for the calculation

$A=70.0, B O=21.0, P C=0.58, D=.019$ 
CALCULATEC EARTH TEMPERATURES AT SELECTED CEPTHS

FOR DIFFUSIVITY $=0.025, A=70.0, B D=21.0$ AND $P O=0.58$

\section{MOVTH OF YEAR}

\section{DEPTH BELOW}

SURFACE(IN)

\begin{tabular}{|c|c|c|c|c|c|c|c|c|c|c|c|c|}
\hline $\begin{array}{l}24.0 \\
48.0 \\
72.0 \\
96.0 \\
20.0\end{array}$ & $\begin{array}{l}54.1 \\
58.7 \\
62.6 \\
65.7 \\
68.0\end{array}$ & $\begin{array}{l}53.9 \\
57.0 \\
60.1 \\
62.9 \\
65.3\end{array}$ & $\begin{array}{l}57.7 \\
58.5 \\
60.1 \\
61.9 \\
63.8\end{array}$ & $\begin{array}{l}65.0 \\
63.2 \\
62.8 \\
63.1 \\
64.0\end{array}$ & $\begin{array}{l}73.4 \\
69.6 \\
67.3 \\
66.1 \\
65.7\end{array}$ & $\begin{array}{l}81.2 \\
76.3 \\
72.7 \\
70.2 \\
68.6\end{array}$ & $\begin{array}{l}85.7 \\
81.1 \\
77.2 \\
74.1 \\
71.9\end{array}$ & $\begin{array}{l}86.1 \\
83.0 \\
79.9 \\
77.1 \\
74.7\end{array}$ & $\begin{array}{l}82.0 \\
81.3 \\
79.8 \\
78.0 \\
76.2\end{array}$ & $\begin{array}{l}74.9 \\
76.7 \\
77.2 \\
76.9 \\
76.0\end{array}$ & $\begin{array}{l}66.2 \\
70.1 \\
72.5 \\
73.7 \\
74.2\end{array}$ & $\begin{array}{l}58.7 \\
63.6 \\
67.2 \\
69.7 \\
71.3\end{array}$ \\
\hline
\end{tabular}

INTEGRATED

AVERAGE FROM

$\begin{array}{llllllllllllll}\text { SURFACE } \quad \text { CO. } 0 \quad 58.4 & 59.8 & 64.0 & 69.6 & 75.6 & 79.9 & 81.6 & 80.1 & 75.9 & 70.1 & 64.3\end{array}$ TO $10 \mathrm{FT}$.

CALCULATEC AUGUST EARTH TEMPERATURE AT SELECTED DIFFUSIVITIES AND SELECTED DEPTHS

DEPTH BELOW

SURFACE (IN)

$$
\begin{array}{r}
24.0 \\
48.0 \\
72.0 \\
96.0 \\
120.0
\end{array}
$$

INTEGRATED AVERAGE FROM SURFACE

TO $10 \mathrm{FT}$.

\begin{tabular}{lcccc}
\multicolumn{5}{c}{ DIFFUSIVITIES } \\
0.010 & 0.020 & 0.025 & 0.030 & 0.040 \\
84.3 & 85.8 & 86.1 & 86.4 & 86.7 \\
79.4 & 82.3 & 83.0 & 83.6 & 84.3 \\
75.3 & 78.9 & 79.9 & 80.7 & 81.8 \\
72.3 & 75.9 & 77.1 & 78.0 & 79.4 \\
70.4 & 73.5 & 74.7 & 75.7 & 77.2
\end{tabular}

78.1

80.8

81.6

82.2

83.1 
EARTH TEMPERATURE STATION

TYPE OF SOIL

TYPE CF EARTH SURFACE

DATA PROCESSED BY

CATA SOURCE

PERICD OF OESERVATION
TEMPLE, TEXAS

UNKNOWN

UNKNOWN

E. M.FITTON

REFERENCE (4)

$1918-1924$

OBSERVED MONTHLY AVERAGE EARTH TEMPERATURES

DEPTH BELOW

SURFACE (IN)

1.0
3.0
6.0
12.0
24.0
36.0
48.0

$53.152 .6 \quad 59.4 \quad 6$

$\begin{array}{lllllll}69.1 & 78.8 & 88.6 & 93.7 & 93.2\end{array}$

$\begin{array}{lllllllll}53.2 & 52.3 & 58.6 & 67.9 & 78.3 & 86.5 & 92.2 & 93.3\end{array}$

$\begin{array}{llllllllll}53.3 & 52.7 & 58.7 & 67.5 & 77.3 & 85.6 & 91.7 & 92.3\end{array}$

$\begin{array}{llllllllll}54.6 & 53.5 & 58.1 & 65.9 & 74.9 & 83.4 & 87.8 & 88.9\end{array}$

$\begin{array}{lllllllll}56.9 & 55.7 & 58.2 & 64.8 & 72.1 & 78.9 & 84.2 & 86.9\end{array}$

$\begin{array}{llllllll}59.6 & 57.4 & 59.0 & 64.2 & 70.2 & 76.4 & 81.7 & 84.4\end{array}$

61.158 .9

MONTH OF YEAR

RESULTS UF LEAST SQUARES ANALYSIS

DEPTH BELDW

SURFACE(IN)

$\operatorname{AVERAGF}(A)$

71.5

$1 \cdot 0$

$3 \cdot 0$

6.0

12.0

24.0

36.0

48.0
71.1

71.0

70.4

70.4

70.8

70.6
AMPLITUDE (B)

21.5
21.0
20.4
18.3
15.6
13.5
12.1

STANDARD

DEVIATION

1.7
1.8
1.6
1.2
0.9
0.7
0.7

\section{CALCULATEC EARTH TEMPERATURES AT OBSERVED CEPTHS 1 *}

DEPTH BELOW

SURFACE (IN)

\section{MONTH OF YEAR}

0.60
$C .64$
0.66
$C .74$
0.90
1.08
1.22

0.60

0.66

C. 74

1.08
D

$\begin{array}{lllll}83.8 & 72.6 \quad 59.8 \quad 52.6\end{array}$ $\begin{array}{llll}73.1 & 60.2 & 52.8\end{array}$ $\begin{array}{llll}73.3 & 60.9 & 53.4\end{array}$ $74.8 \quad 62.9 \quad 55.4$ $76.367 .0 \quad 59.5$

$78.7 \quad 71.0 \quad 62.9$ 79.273 .265 .0

$\begin{array}{rlllllllllllll}1.0 & 50.3 & 52.2 & 58.7 & 68.9 & 79.4 & 87.9 & 91.6 & 89.9 & 82.8 & 72.9 & 62.1 & 54.0 \\ 3.0 & 50.9 & 52.5 & 58.6 & 68.5 & 78.7 & 87.2 & 91.1 & 89.6 & 83.0 & 73.4 & 62.8 & 54.7 \\ 6.0 & 51.7 & 52.9 & 58.5 & 67.9 & 77.8 & 86.1 & 90.2 & 89.2 & 83.1 & 74.0 & 63.8 & 55.8 \\ 12.0 & 53.3 & 53.7 & 58.4 & 66.8 & 76.0 & 84.1 & 88.6 & 88.3 & 83.3 & 75.1 & 65.6 & 57.7 \\ 24.0 & 56.4 & 55.6 & 58.6 & 65.1 & 73.0 & 80.6 & 85.4 & 86.4 & 83.2 & 76.7 & 68.6 & 61.3 \\ 36.0 & 59.3 & 57.6 & 59.2 & 64.2 & 70.8 & 77.6 & 82.5 & 84.4 & 82.6 & 77.7 & 70.9 & 64.3 \\ 48.0 & 61.9 & 59.5 & 60.1 & 63.7 & 69.1 & 75.2 & 79.9 & 82.4 & 81.8 & 78.2 & 72.6 & 66.8\end{array}$




\section{CALCULATEC EARTH TEMPERATURES AT SELECTED CEPTHS}

FOR DIFFUSIVITY $=0.025, A=71.0, B O=21 . \mathrm{C}$ AND $P O=0.59$

DEPTH BELOW

SURFACE (IN)

\section{MCNTH OF YEAR}

$$
\begin{aligned}
& \begin{array}{lllllllllllllllll}
24.0 & 55.2 & 54.9 & 58.6 & 65.8 & 74.3 & 82.1 & 86.7 & 87.2 & 83.1 & 76.0 & 67.3 & 59.8
\end{array} \\
& \begin{array}{llllllllllllll}
48.0 & 59.8 & 58.0 & 59.5 & 64.1 & 70.5 & 77.2 & 82.0 & 84.0 & 82.4 & 77.8 & 71.2 & 64.7
\end{array} \\
& \begin{array}{lllllllllllllll}
72.0 & 63.7 & 61.1 & 61.1 & 63.7 & 68.2 & 73.6 & 78.1 & 80.9 & 80.9 & 78.3 & 73.6 & 68.3
\end{array} \\
& \begin{array}{lllllllllllllll}
96.0 & 66.7 & 63.9 & 62.9 & 64.1 & 67.0 & 71.1 & 75.1 & 78.0 & 79.1 & 77.9 & 74.8 & 70.8
\end{array}
\end{aligned}
$$
IVTEGRATED

AVERAGE FROM

$\begin{array}{lllllllllllllllll}\text { SURFACE } & 61.1 & 59.4 & 60.7 & 64.9 & 70.5 & 76.5 & 80.8 & 82.6 & 81.1 & 77.0 & 71.2 & 65.4\end{array}$ Tก $10 \mathrm{FT}$.

CALCULATEC AUGUST EARTH TEMPERATURE AT SELECTED DIFFUSIVITIES AND SELECTED DEPTHS

DEPTH BELOW

SURFACE (IN)

$$
24.0
$$

48.0

72.0

96.0

120.0

INTEGRATED

AVERAGE FROM

SURFACE

TO $10 \mathrm{FT}$.

\begin{tabular}{lcccc}
\multicolumn{5}{c}{ DIFFUSIVITIES } \\
0.010 & 0.020 & 0.025 & 0.030 & 0.040 \\
85.3 & 86.8 & 87.2 & 87.4 & 87.8 \\
80.4 & 83.2 & 84.0 & 84.6 & 85.3 \\
76.2 & 79.8 & 80.9 & 81.7 & 82.8 \\
73.2 & 76.9 & 78.0 & 79.0 & 80.4 \\
71.4 & 74.5 & 75.7 & 76.6 & 78.2
\end{tabular}

79.1

81.8

82.6

83.2

$84 \cdot 1$ 
EARTH TEMPERATURE STATION

TYPE CF SOIL

TYPE OF EARTH SURFACE

DATA PROCESSED BY

DATA SOURCE

PERIOD OF OQSERVATION
SALT LAKE CITY, UTA

SANDY LOAM

BARE

CLIMATOLOGICAL DATA

$1960-1962$

OBSERVED MONTHLY AVERAGE EARTH TEMPERATURES

\section{DEPTH BELOW}

SURFACE (IN)
MONTH DF YEAR

$\begin{array}{rlllllllllllll}4.0 & 30.5 & 33.5 & 39.0 & 52.5 & 60.7 & 67.9 & 71.2 & 69.1 & 60.4 & 51.1 & 40.0 & 32.1 \\ 8.0 & 31.3 & 33.5 & 38.8 & 51.7 & 59.6 & 67.0 & 70.5 & 69.3 & 60.7 & 52.1 & 41.2 & 33.2 \\ 20.0 & 32.0 & 34.4 & 38.2 & 49.0 & 56.1 & 63.2 & 67.1 & 67.5 & 60.3 & 53.3 & 43.7 & 36.1 \\ 39.0 & 37.1 & 35.0 & 39.0 & 47.4 & 55.2 & 60.1 & 64.9 & 66.8 & 61.4 & 55.8 & 46.3 & 40.7\end{array}$

RESLLTS OF LEAST SQUARES ANALYSIS

DEPTH BELOW

SURFACE (IN)

AVERAGF (A)

AMPLITUDE (B)

PHASE ANGLE(P)
20.6
20.0
17.5
15.3

C. 51

0.55

C. 66

0.81
STANDARD

DEVIATION

$2 \cdot 6$
$2 \cdot 5$
$2 \cdot 3$
2.1

CALCULATED EARTH TEMPERATURES AT OBSERVED CEPTHS(*)

DEPTH BELOW

MONTH OF YEAR

SURFACE (IN)

$\begin{array}{llllllllllllllll}4.0 & 30.7 & 33.5 & 40.6 & 51.0 & 61.0 & 68.6 & 71.3 & 68.5 & 60.9 & 50.9 & 40.6 & 33.3\end{array}$

$\begin{array}{llllllllllllllll}8.0 & 31.4 & 33.8 & 40.4 & 50.3 & 60.1 & 67.7 & 70.6 & 68.3 & 61.1 & 51.5 & 41.5 & 34.2\end{array}$

$20.0 \quad 33.4 \quad 34.7 \quad 40.0 \quad 48.6 \quad 57.6 \quad 65.0 \quad 68.6 \quad 67.4 \quad 61.7 \quad 53.3 \quad 44.0 \quad 36.9$

$\begin{array}{llllllllllllllll}39.0 & 36.5 & 36.3 & 39.8 & 46.6 & 54.3 & 61.3 & 65.4 & 65.7 & 61.9 & 55.3 & 47.3 & 40.6\end{array}$

(*) BASIC parameters used for the calculation

$A=51.0, B 0=21.0, P C=0.48, C=.035$ 


\section{CALCULATED EARTH TEMPERATURES AT SELECTED DEPTHS}

FOR DIFFUSIVITY $=0.025, A=51.0, B O=21.0$ AND $P O=0.48$

DEPTH BELOW

SURFACE (IN)

MONTH OF YEAR

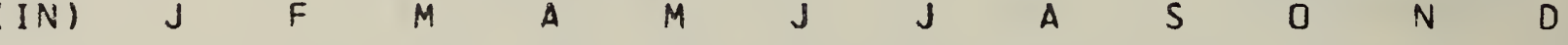
$24.0 \quad 34.8 \quad 35.4 \quad 39.8 \quad 47.6 \quad 56.0 \quad 63.3 \quad 67.2 \quad 66.7 \quad 61.8 \quad 54.3 \quad 45.6 \quad 38.6$ $\begin{array}{llllllllllllll}48.0 & 39.2 & 38.0 & 40.2 & 45.4 & 51.9 & 58.4 & 62.7 & 64.0 & 61.6 & 56.5 & 49.8 & 43.5\end{array}$ $\begin{array}{lllllllllllll}72.0 & 42.9 & 40.9 & 41.4 & 44.5 & 49.3 & 54.6 & 58.9 & 61.1 & 60.5 & 57.4 & 52.5 & 47.3\end{array}$ $96.0 \quad 46.0 \quad 43.5 \quad 43.0 \quad 44.6 \quad 47.8 \quad 52.0 \quad 55.8 \quad 58.4 \quad 59.0 \quad 57.4 \quad 54.0 \quad 49.9$ $\begin{array}{lllllllllllllll}120.0 & 48.4 & 45.9 & 44.7 & 45.2 & 47.2 & 50.3 & 53.5 & 56.1 & 57.3 & 56.8 & 54.7 & 51.7\end{array}$ INTEGRATED

AVERAGE FROM

SURFACE $40.5 \quad 39.5 \quad 41.4 \quad 46.0 \quad 51.8 \quad 57.6 \quad 61.4 \quad 62.5 \quad 60.4 \quad 55.9 \quad 49.9 \quad 44.4$ TO $10 \mathrm{FT}$.

CALCULATEC AUGUST EARTH TEMPERATURE AT SELECTED DIFFUSIVITIES AND SELECTED DEPTHS

DEPTH BELOW

SURFACE ( IN)

24.0

48.0

72.0

96.0

120.0

INTEGRATED

AVERAGE FROM

SURFACE

TO $10 \mathrm{FT}$.

\begin{tabular}{lllll}
\multicolumn{5}{c}{ DIFFUSIVITIES } \\
0.010 & 0.020 & 0.025 & 0.030 & 0.040 \\
& & & & \\
05.1 & 66.4 & 66.7 & 66.9 & 67.2 \\
60.7 & 63.3 & 64.0 & 64.5 & 65.1 \\
56.7 & 60.1 & 61.1 & 61.8 & 62.9 \\
53.7 & 57.3 & 58.4 & 59.3 & 60.7 \\
51.7 & 54.9 & 56.1 & 57.1 & 58.5
\end{tabular}

59.3

$61 \cdot 8$

$62 \cdot 5$

63.1

63.9 
EARTH TEMPERATURE STATION

TYPE CF SOIL

TYPE CF EARTH SURFACE

DATA PROCESSEO BY

DATA SOURCE

PERIOD OF OBSERVATINN
BURLINGTON, VT. UNKNOWN

BARE

JEN-HU-CHANG

REFERENCE ( 5 )

$1951-1955$

OBSERVED MONTHLY AVERAGE EARTH TEMPERATURES

DEPTH BELOW

MONTH OF YEAR

SURFACE ( IN)

$\begin{array}{llllllllllllllllll}0.2 & 29.5 & 29.6 & 32.7 & 45.5 & 58.6 & 69.9 & 78.2 & 72.1 & 62.5 & 49.4 & 38.0 & 32.2\end{array}$

$\begin{array}{llllllllllllll}1.0 & 29.5 & 30.0 & 34.5 & 45.7 & 58.2 & 69.8 & 77.2 & 71.5 & 61.7 & 48.3 & 37.4 & 32.5\end{array}$

$\begin{array}{lllllllllllll}3.0 & 29.6 & 29.8 & 32.7 & 45.0 & 57.7 & 69.2 & 76.3 & 71.4 & 61.4 & 48.8 & 37.4 & 32.8\end{array}$

DEPTH BELOW

SURFACE (IN) AVERAGE (A)

0.2
1.0
3.0

50.0

49.8

49.5
AMPLITUDE (B) PHASE ANGLE(P)

0.62

0.59

C.61
STANDARD

DEVIATION

2.7

2.6

2.6 


\section{CALCULATEL EARTH TEMPERATURES AT SELECTED [EPTHS}

FOR DIFFUSIVITY $=0.025, A=49.0, B O=26.0$ AND $P D=0.60$

\section{DEPTH BELOW}

SURFACE (IN)

$$
\begin{aligned}
& 24.0 \\
& 48.0 \\
& 72.0 \\
& 96.0
\end{aligned}
$$

120.0

INTEGRATED

\section{MONTH OF YEAR}

\section{AVERAGE FROM}

SURFACE

TO 10 FT.

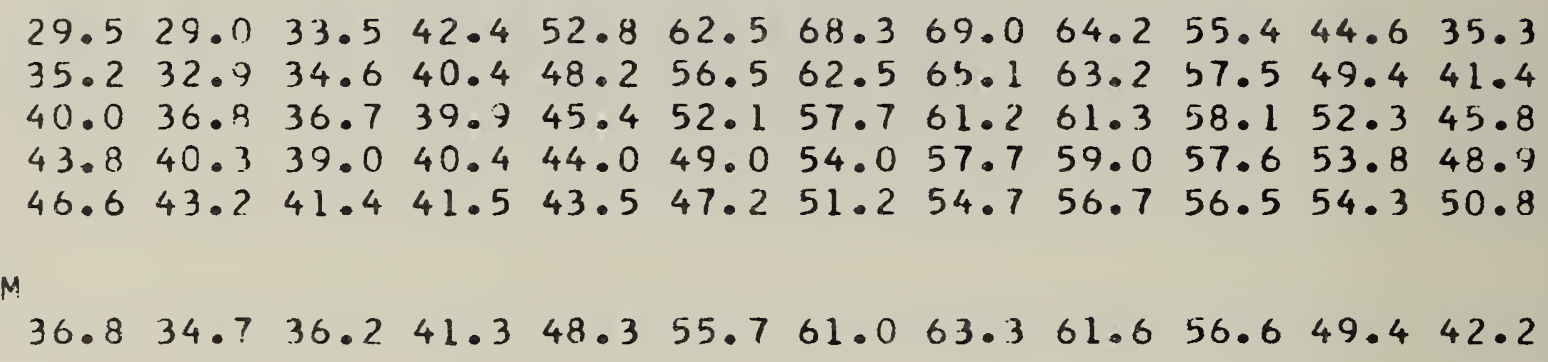

CALCULATEC AUGUST EARTH TEMPERATURE AT SELECTED DIFFUSIVITIES AIND SELECTED DEPTHS

\section{DEPTH BELOW}

SURFACE (IN)

$$
24.0
$$

48.0

72.0

96.0

120.0

INTEGRATED

AVERAGE FROM

SURFACE

TO $10 \mathrm{FT}$.

$\begin{array}{cc} & \text { DIFFUSIVITIES } \\ 0.010 & 0.020 \\ 66.8 & 68.6 \\ 60.6 & 64.2 \\ 55.4 & 59.9 \\ 51.7 & 56.2 \\ 49.5 & 53.2\end{array}$

0.025

0.030

0.040

69.0

69.4

65.8

62.2

58.8

55.9

69.8

65.1

61.2

57.7

54.7

66.8

63.6

60.6

57.8

59.0

62.3

63.3

64.1

65.2 


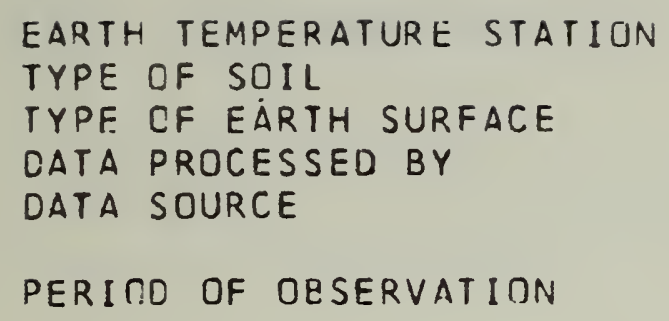

UBSERVED MONTHLY AVERAGE EARTH TEMPERATURES

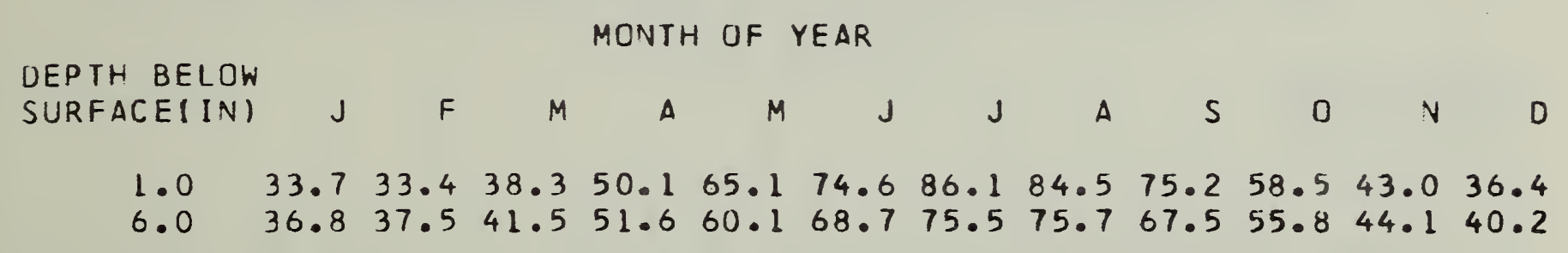

MONTH OF YEAR

RESLLTS OF I.EAST SQUARES ANALYSIS

DEPTH BELOW SURFACE (IN)

AVERAGF (A)

$\begin{array}{ll}1.0 & 56.7 \\ 6.0 & 54.7\end{array}$

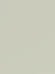


CALCULATED EARTH TEMPERATURES AT SELECTED CEPTHS FOR DIFFUSIVITY $=0.025, A=48.0, B O=22.0$ AND $P O=0.60$

\section{DEPTH BELOW} SURFACE(IN)

$$
\text { MONTH OF YEAR }
$$

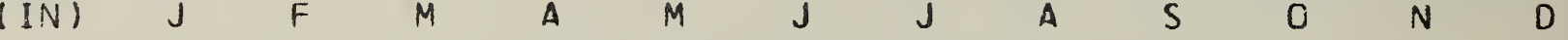

$$
\begin{array}{rllllllllllll}
24.0 & 31.5 & 31.1 & 34.9 & 42.4 & 51.3 & 59.5 & 64.4 & 65.0 & 60.8 & 53.4 & 44.3 & 36.4 \\
48.0 & 36.4 & 34.4 & 35.9 & 40.7 & 47.3 & 54.3 & 59.5 & 61.6 & 60.0 & 55.2 & 48.3 & 41.6 \\
72.0 & 40.4 & 37.7 & 37.6 & 40.3 & 44.9 & 50.6 & 55.4 & 58.3 & 58.4 & 55.7 & 50.8 & 45.3 \\
96.0 & 43.6 & 40.6 & 39.6 & 40.7 & 43.7 & 48.0 & 52.2 & 55.3 & 56.4 & 55.3 & 52.1 & 47.9 \\
120.0 & 46.0 & 43.1 & 41.6 & 41.6 & 43.4 & 46.5 & 49.8 & 52.8 & 54.5 & 54.4 & 52.5 & 49.5
\end{array}
$$

INTEGRATED

AVERAGE FROM

SURFACE

$37.6 \quad 35.9 \quad 37.2 \quad 41.5 \quad 47.4 \quad 53.6 \quad 58.2 \quad 60.1 \quad 58.7 \quad 54.4 \quad 48.3 \quad 42.3$

TO $10 \mathrm{FT}$.

CALCULATED AUGUST EARTH TEMPERATURE AT SELECTED DIFFUSIVITIES AND SELECTED DEPTHS

DEPTH BELOW

SURFACE (IN)

24.0

48.0

72.0

96.0

120.0

INTEGRATED

AVERAGE FROM

SURFACE

TO $10 \mathrm{FT}$.

\begin{tabular}{lclll}
\multicolumn{5}{c}{ CIFFUSIVITIES } \\
0.010 & 0.020 & 0.025 & 0.030 & 0.040 \\
63.0 & 64.6 & 65.0 & 65.2 & 65.6 \\
57.8 & 60.8 & 61.6 & 62.2 & 63.0 \\
53.4 & 57.2 & 58.3 & 59.2 & 60.4 \\
50.3 & 54.1 & 55.3 & 56.3 & 57.8 \\
48.4 & 51.6 & 52.8 & 53.9 & 55.5 \\
& & & & \\
56.5 & 59.3 & 60.1 & 60.8 & 61.7
\end{tabular}




\section{EARTH TEMPERATURE STATION}

TYPE CF SOIL

TYPE CF EARTH SURFACE

DATA PROCESSED BY

DATA SOURCE

PERIOC OF OESERVATION
PULLMAN, WASH.

$S T-62$

UNKNOWN

BLUE GRASS SOD

E.N.FITTON

REFERENCE (4)

$1912-1913$

\section{OBSERVED MONTHLY AVERAGE EARTH TEMPERATURES}

DEPTH BELOW
SURFACE(IN)
$\begin{array}{rl}1.0 & 31.7 \\ 2.0 & 31.9 \\ 6.0 & 32.3 \\ 12.0 & 32.7 \\ 24.0 & 35.6 \\ 36.0 & 37.5\end{array}$

$$
\text { MONTH OF YEAR }
$$

$\begin{array}{rrrrrrrrrr}M & A & M & J & J & A & S & 0 & N & D \\ 46.5 & 60.2 & 62.7 & 66.0 & 75.4 & 60.2 & 42.0 & 40.0 & 33.2 \\ 45.4 & 57.8 & 63.2 & 65.9 & 73.2 & 58.9 & 42.0 & 39.9 & 33.7 \\ 44.7 & 54.9 & 62.3 & 64.8 & 70.2 & 57.2 & 42.4 & 40.4 & 34.5 \\ 44.8 & 52.8 & 62.2 & 64.9 & 67.7 & 56.7 & 45.0 & 42.2 & 36.0 \\ 44.3 & 50.6 & 59.0 & 62.8 & 66.5 & 58.5 & 48.5 & 45.0 & 39.2 \\ 44.1 & 48.9 & 56.3 & 60.9 & 64.8 & 58.9 & 50.9 & 47.4 & 41.9\end{array}$

RESLLTS OF LEAST SQUARES ANALYSIS

DEPTH BELOW

SURFACE (IN)
AMPLITUDE (B)
19.8
19.2
17.8
16.8
14.7
13.0

STANDARD DEVIATION
4.9
4.3
3.7
2.8
2.2
1.8 
CALCULATEC FARTH TEMPERATURES AT SELECTED CEPTHS FOR DIFFUSIVITY $=0.025, A=48.0 . B(1=19.0$ AND $P O=0.50$

DEPTH BELOW
SURFACE (IN)

DEPTH BELOW
SURFACE (IN)

24.0

48.0

72.0

96.0

120.0

INTEGRATED

AVERAGE FROM

SURFACE

TO $10 \mathrm{FT}$.

\section{MONTH OF YEAR}

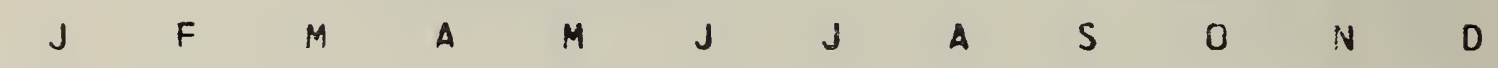

$$
\begin{array}{llllllllllll}
33.4 & 33.8 & 37.7 & 44.6 & 52.3 & 59.0 & 62.6 & 62.3 & 58.0 & 51.2 & 43.4 & 37.0 \\
37.4 & 36.3 & 38.1 & 42.7 & 48.6 & 54.5 & 58.5 & 59.7 & 57.7 & 53.2 & 47.1 & 41.4 \\
40.8 & 38.9 & 39.2 & 42.0 & 46.3 & 51.1 & 55.0 & 57.1 & 56.7 & 54.0 & 49.5 & 44.8 \\
43.6 & 41.3 & 40.7 & 42.1 & 45.0 & 48.8 & 52.2 & 54.7 & 55.2 & 53.9 & 50.9 & 47.2 \\
45.7 & 43.4 & 42.3 & 42.7 & 44.4 & 47.2 & 50.1 & 52.5 & 53.7 & 53.3 & 51.4 & 48.7
\end{array}
$$

$\begin{array}{lllllllllllll}38.6 & 37.6 & 39.2 & 43.3 & 48.5 & 53.8 & 57.3 & 58.4 & 56.7 & 52.6 & 47.2 & 42.2\end{array}$

\section{CALCULATEC AUGUST EARTH TEMPERATURE AT SELECTED DIFFUSIVITIES AND SELECTED DEPTHS}

DEPTH BELOW

SURFACE(IN)

24.0
48.0
72.0
96.0
120.0

I ITTEGRATED

AVERAGE FROM

SURFACE

TO $10 \mathrm{FT}$.

\begin{tabular}{lclll}
\multicolumn{5}{c}{ DIFFUSIVITIES } \\
0.010 & 0.020 & 0.025 & 0.030 & 0.040 \\
& & & & \\
60.8 & 62.0 & 62.3 & 62.5 & 62.8 \\
56.7 & 59.1 & 59.7 & 60.2 & 60.8 \\
53.1 & 56.2 & 57.1 & 57.8 & 58.8 \\
50.3 & 53.6 & 54.7 & 55.5 & 56.7 \\
48.6 & 51.5 & 52.3 & 53.4 & 54.8
\end{tabular}

55.5

57.8

58.4

59.0

59.7 
EARTH TEMPERATURE STATION

TYPE CF SOIL

TYPE OF EARTH SURFAT.E

DATA PRUCESSED BY

UATA SUURCE

PERIOD OF OESERVATION
SEATTLE, WASH.

$S T-63$

SAND OVER CLAY

BLLE GRASS

JFN-HU-CHANG

REFERENCE (5)

$1948-1950$

OBSERVED MONTHLY AVERAGE EARTH TEMPERATURES

DEPTH BELOW

MONTH OF YEAR

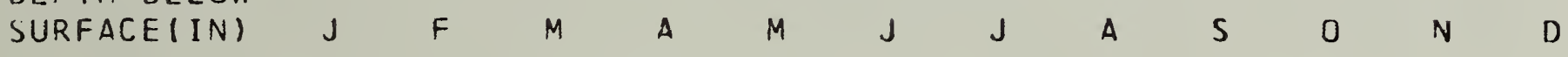

$\begin{array}{llllllllllllllll}19.7 & 38.9 & 39.6 & 45.4 & 49.7 & 55.7 & 60.4 & 62.8 & 64.3 & 61.9 & 55.3 & 50.1 & 45.0\end{array}$

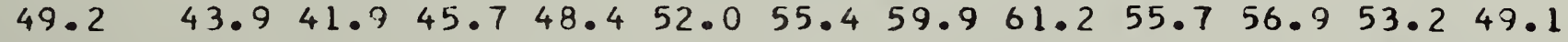

$\begin{array}{lllllllllllllll}88.6 & 48.3 & 45.1 & 46.5 & 48.5 & 50.9 & 52.6 & 56.0 & 57.7 & 58.2 & 56.7 & 54.1 & 51.8\end{array}$

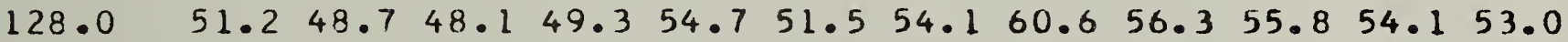

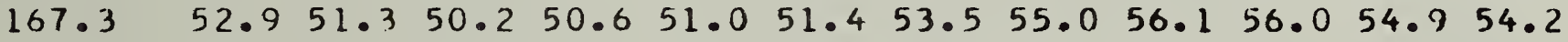

$\begin{array}{lllllllllllll}206.7 & 52.3 & 52.4 & 51.7 & 51.2 & 51.2 & 51.3 & 52.8 & 53.9 & 54.5 & 54.7 & 54.1 & 53.9\end{array}$

DEPTH BELOW

RESLLTS OF LEAST SQUARES ANALYSIS
AVERAGE (A)

52.5
52.0
52.2
53.1
53.1
52.8

AMPL ITUDE (B)

$$
\begin{array}{r}
12.1 \\
8.2 \\
6.0 \\
4.3 \\
2.9 \\
1.8
\end{array}
$$

\section{PHASE ANGLE(P)}

0.79
1.04
1.37
1.40
1.95
2.14

STANDARD DEVIATION

1.2
1.6
0.7
1.9
0.3
0.4

\section{CALCULATED EARTH TEMPERATURES AT OBSERVED [EPTHS(*)}

\section{DEPTH BELOW}

SURFACE (IN)

MONTH OF YEAR

$\begin{array}{rllllllllllll}19.7 & 40.8 & 40.7 & 43.6 & 49.3 & 55.8 & 61.7 & 65.1 & 65.3 & 62.1 & 56.6 & 49.9 & 44.2 \\ 49.2 & 44.5 & 43.1 & 44.3 & 47.9 & 52.7 & 57.8 & 61.4 & 62.9 & 61.6 & 58.1 & 53.0 & 48.2 \\ 88.6 & 48.4 & 46.4 & 46.0 & 47.6 & 50.5 & 54.2 & 57.5 & 59.6 & 59.9 & 58.4 & 55.3 & 51.8 \\ 128.0 & 51.1 & 49.1 & 48.0 & 48.3 & 49.7 & 52.2 & 54.7 & 56.9 & 58.0 & 57.7 & 56.2 & 53.8 \\ 167.3 & 52.9 & 51.1 & 49.9 & 49.4 & 49.9 & 51.3 & 53.1 & 54.9 & 56.2 & 56.6 & 56.1 & 54.7 \\ 206.7 & 53.7 & 52.4 & 51.3 & 50.5 & 50.5 & 51.1 & 52.2 & 53.5 & 54.8 & 55.5 & 55.5 & 54.9\end{array}$




\section{CALCULATED EARTH TEMPERATURES AT SELECTED CEPTHS}

FOR DIFFUSIVITY $=0.025, A=53.0, B O=15.0$ AND $P O=0.64$

DEPTH BELOW

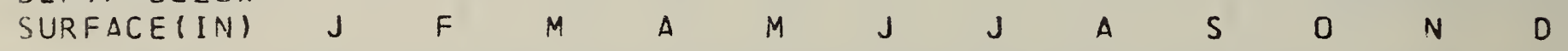

$$
\text { MONTH OF YEAR }
$$

$24.0 \quad 41.9 \quad 41.4 \quad 43.7 \quad 48.8 \quad 54.8 \quad 60.4 \quad 64.0 \quad 64.7 \quad 62.1 \quad 57.1 \quad 50.945 .5$

$\begin{array}{lllllllllllllll}48.0 & 45.3 & 43.7 & 44.6 & 47.7 & 52.2 & 57.0 & 60.6 & 62.3 & 61.3 & 58.2 & 53.6 & 48.7\end{array}$

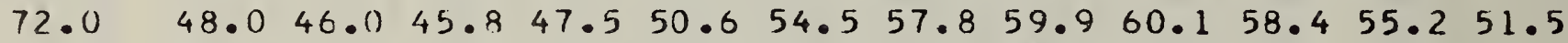

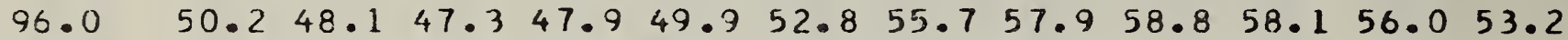

$120.0 \quad 51.8 \quad 49.8 \quad 48.7 \quad 48.6 \quad 49.7 \quad 51.8 \quad 54.1 \quad 56.2 \quad 57.4 \quad 57.4 \quad 56.2 \quad 54.2$ INTEGR $\triangle T E D$

AVERAGE FROM

SURFACE

$46.144 .9 \quad 45.5 \quad 48.3 \quad 52.2 \quad 56.5 \quad 59.8 \quad 61.2 \quad 60.4 \quad 57.7 \quad 53.5 \quad 49.4$ TD $10 \mathrm{FT}$.

\section{CALCULATED AUGUST EARTH TEMPERATURE AT SELECTED DIFFUSIVITIES AND SELECTED DEPTHS}

DEPTH BELOW

SURFACE (IN)

$$
\begin{array}{r}
24.0 \\
48.0 \\
72.0 \\
96.0 \\
120.0
\end{array}
$$

INTEGRATED

AVERAGE FROM

SURFACE

TO $10 \mathrm{FT}$.
CIFFUSIVITIES

$\begin{array}{lllll}0.010 & 0.020 & 0.025 & 0.030 & 0.040 \\ 63.3 & 64.4 & 64.7 & 64.9 & 65.1 \\ 59.0 & 61.7 & 62.3 & 62.7 & 63.3 \\ 56.6 & 59.2 & 59.9 & 60.5 & 61.4 \\ 54.5 & 57.0 & 57.9 & 58.6 & 59.6 \\ 53.2 & 55.3 & 56.2 & 56.9 & 58.0\end{array}$

58.7

60.7

$61 \cdot 2$

61.7

62.4 
